\title{
Jamstvo perspektive u transdisciplinarnoj organizaciji znanja
}

\section{Kos, Denis}

\section{Doctoral thesis / Disertacija}

2021

Degree Grantor / Ustanova koja je dodijelila akademski / stručni stupanj: University of Zagreb, Faculty of Humanities and Social Sciences / Sveučilište u Zagrebu, Filozofski fakultet

https://doi.org/10.17234/diss.2021.8643

Permanent link / Trajna poveznica: https://urn.nsk.hr/urn:nbn:hr:131:508403

Rights / Prava: In copyright/Zaštićeno autorskim pravom.

Download date / Datum preuzimanja: 2023-04-26

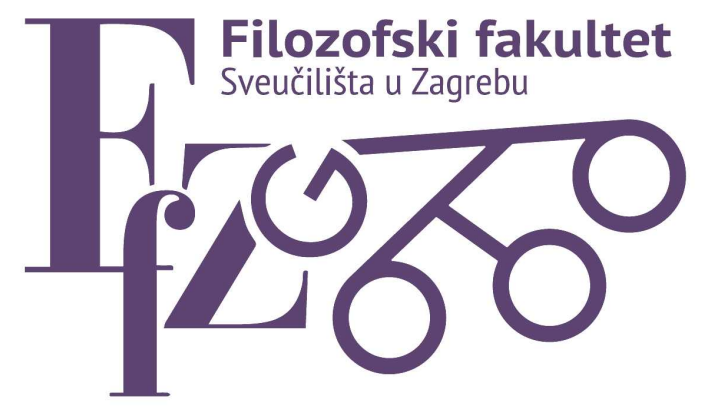

Repository / Repozitorij:

ODRAZ - open repository of the University of Zagreb

Faculty of Humanities and Social Sciences
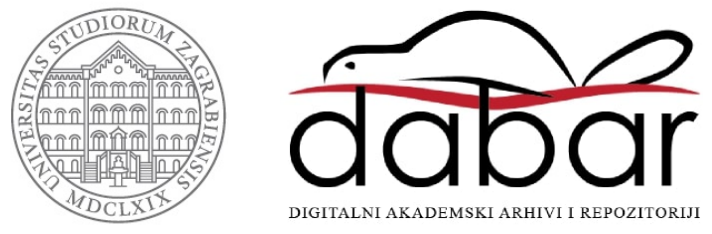
Filozofski fakultet

Denis Kos

\title{
JAMSTVO PERSPEKTIVE U TRANSDISCIPLINARNOJ ORGANIZACIJI ZNANJA
}

\author{
DOKTORSKI RAD
}

Mentori:

prof. dr. sc. Sonja Špiranec

prof. dr. sc. Ante Čović

Zagreb, 2021. 


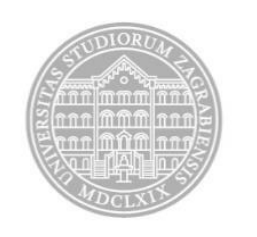

University of Zagreb

Faculty of Humanities and Social Sciences

Denis Kos

\title{
VIEWPOINT WARRANT IN TRANSDISCIPLINARY \\ KNOWLEDGE ORGANIZATION
}

\author{
DOCTORAL THESIS
}

Supervisors:

prof. Sonja Špiranec, PhD

prof. Ante Čović, PhD

Zagreb, 2021 


\section{Informacije o mentorima}

Sonja Špiranec diplomirala je na Filozofskom fakultetu Sveučilišta u Zagrebu 1998. godine germanistiku i informatologiju, magistrirala 2005. godine, a doktorsku disertaciju pod naslovom Model organizacije informacija u elektroničkoj obrazovnoj okolini obranila je 2007. godine. 1998. godine zapošljava se u Nacionalnoj i sveučilišnoj knjižnici u Zagrebu, a 2004. godine prelazi na Odsjek za informacijske znanosti u Zagrebu, gdje sada djeluje kao redovita profesorica. Na Odsjeku sudjeluje u preddiplomskoj, diplomskoj i poslijediplomskoj nastavi. Voditeljica je Doktorskog studija informacijskih i komunikacijskih znanosti, Zavoda za informacijske studije i Izvanrednog studija knjižničarstva. Kao znanstvenica u području informacijskih i komunikacijskih znanosti priznata je u domaćoj i međunarodnoj znanstvenoj zajednici, a posebice u područjima informacijske pismenosti i predmetnog označivanja. Kao suinicijatorica Europske konferencije o informacijskoj pismenosti (ECIL) od 2013. godine suorganizatorica je i predsjednica Programskog odbora te konferencije. Članica je Programskih odbora i drugih međunarodnih i domaćih znanstvenih skupova. Sudjeluje kao suradnica na znanstvenim projektima, a na nekoliko međunarodnih istraživačkih projekata sudjelovala je kao nacionalni predstavnik. Djeluje kao članica Upravnog odbora Hrvatskog informacijskog $i$ dokumentacijskog društva (HID), članica Komisije za klasifikaciju i predmetno označivanje Hrvatskog knjižničarskog društva (HKD) te članica Međunarodnog udruženja za organizaciju znanja (ISKO). Redovito sudjeluje na brojnim domaćim i međunarodnim znanstvenim skupovima te je održala nekoliko pozvanih izlaganja na temu informacijske pismenosti i obrazovanju u elektroničkoj obrazovnoj okolini. Izabrane publikacije:

1. Grubišić, Marina; Špiranec, Sonja. Can Societal Impact of Scientific Work Be Measured in the Process of Re-Accreditation of Higher Education Institutions and Public Scientific Institutes in Croatia?// INFuture2019: Knowledge in the Digital Age. Zagreb: FF press, 2019. pp. 49-55.

2. Špiranec, Sonja; Kos, Denis; Michael, George. Searching for critical dimensions in data literacy// Information Research, 24 (2019), 4; 1922, 12.

3. Lazić, Nikolaj; Špiranec, Sonja; Lasić Lazić, Jadranka. The Conceptual and Organisational Features of the Doctoral Programme in Information and Communication Sciences at the University of Zagreb // INTED2019 Proceedings Valencia, Spain: IATED, 2019. pp. 7939-7947. 
4. Kos, Denis; Špiranec, Sonja; Čović, Ante Mapping perspectival ambiguity in Bioethics : revisiting the viewpoint warrant // Challenges and Opportunities for Knowledge Organization in the Digital Age : proceedings of the Fifteenth International ISKO Conference, 9-11 July, 2018, Porto, Portugal / Ribeiro, Fernanda ; Cerveira, Maria Elisa (ed.). Porto: International Society for Knowledge Organization (ISKO) ; University of Porto, Faculty of Arts and Humanities ; Research Centre in Communication, Information and Digital Culture, 2018. pp. 959-961.

5. Ferlindeš, Josip; Špiranec, Sonja The theoretical-philosophical foundation of library and information science in the Philosophy of information // Vjesnik bibliotekara Hrvatske, 61 (2018), 1; 37-56.

Ante Čović rođen je 1949. u Splitu. Na Filozofskom fakultetu Sveučilišta u Zagrebu diplomirao je 1975. filozofiju i latinski jezik, a doktorsku disertaciju obranio 1989. Od 1976. godine zaposlen je na Katedri za etiku na Odsjeku za filozofiju Filozofskog fakulteta Sveučilišta u Zagrebu, gdje je sada redovni profesor u trajnom zvanju. Djelovao je i kao pročelnik Odsjeka za filozofiju, a trenutno djeluje kao prorektor Sveučilišta u Zagrebu. Akademske godine 1989./1990. boravio je na Sveučilištu u Augsburgu kao stipendist zaklade Alexander von Humboldt. Potporom iste zaklade bio je 1999. na studijskom boravku u Međufakultetskom centru za etiku u prirodnim znanostima Sveučilišta u Tübingenu, a odmah zatim na dvomjesečnoj istraživačkoj stipendiji na Institutu za teologiju i društvo Sveučilišta Bundeswehr u Münchenu. Spada među prve hrvatske znanstvenike koji su se sustavno bavili bioetičkom problematikom. Glavni je i odgovorni urednik časopisa Filozofska istraživanja i Synthesis philosophica, te pokretač i urednik biblioteke Bioetika kod izdavačke kuće Pergamena. Bio je voditelj triju znanstveno-istraživačkih projekata i jednog istraživačkog programa, financiranih od strane Ministarstva znanosti, obrazovanja i sporta, kao i voditelj međunarodnog znanstvenog projekta Bioethik im südosteuropäischen Raum. Chancen, Probleme und praktische Perspektiven der Konstitution öffentlicher ethischer Diskurse unter Umbruchsbedingungen i međunarodnog znanstvenog programa Südosteuropäisches Netzwerk 'Integrative Bioethik', financiranih od strane DAAD i Volskwagen-Stiftung. Inicijator je osnivanja i predsjednik Organizacijskog odbora znanstveno-kulturne manifestacije Lošinjski dani bioetike, osnivač i kodirektor konferencije Bioetički forum za jugoistočnu Europu te poslijediplomskog tečaja Međunarodna ljetna škola integrativne bioetike, kao i voditelj Referalnog centra za bioetiku u jugoistočnoj Europi. Osnivač je i voditelj Znanstvenog centra izvrsnosti za integrativnu bioetiku. Izabrane publikacije: 
1. Čovića, A. Integrative Bioethik und das Problem der Wahrheit // Integrative Bioethik und Pluriperspektivismus. Integrative Bioethics and Pluri-Perspectivism. Academia Verlag, Sankt Augustin, 2010. Str. 44-54.

2. Čovića, A. The Europeanization of Bioethics // A. Muzur, H.-M. Sass (ur.) / Fritz Jahr and the Foundations of Global Bioethics: The Future of Integrative Bioethics. Lit Verlag, Zürich- Münster, 2012. Str. 193-196.

3. Čovića, A. Epochal Orientation, New Ethical Culture, and Integrative Bioethics // Formosan Journal of Medical Humanities, 19 (2018), vol. 1-2, pp. 19-30.

4. Čovića, A. Besmisao »primijenjene etike: Od etičkog vakuuma do etičkog apsurda //. Filozofska istraživanja, 153 (1/2019), pp. 247-264.

5. Čovića, A. Ethicisation in the Light of Law and Morality Dichotomy // Synthesis Philosophica, 34 (1/2019), pp. 87-103. 


\section{ZAHVALE}

Profesorici dr. sc. Sonji Špiranec, bez čije stručnosti, snage i otvorenosti ovog doktorata nikada ne bi ni bilo, zahvalan sam za svaki moment mentorske pažnje, sve sate prijateljskog razgovora i njenu duboku iskrenost u svakoj zajedničkoj radosti. Draga Sonja, hvala Ti na nenadomjestivoj podršci i povjerenju od studentskih dana, prvih radova, istraživanja i konferencija pa sve do samog kraja formalnog obrazovanja i ove disertacije!

Profesorima dr. sc. Anti Čoviću i dr. sc. Hrvoju Juriću zahvalan sam za uvod u područje integrativne bioetike, pristup dokumentacijskim zbirkama i osiguranju vrhunskih uvjeta za pisanje ove disertacije, no prije svega za povjerenje, ljudsku i stručnu podršku, ali i životne pouke koje sežu mnogo dalje od ovog rada.

Posebno zahvaljujem i profesoricama dr. sc. Mihaeli Banek Zorici i dr. sc. Jadranki Lasić Lazić bez kojih nikada ne bih bio u prilici alate naših znanosti suvereno držati u rukama.

Riječi zahvale dugujem kolegi i znanstveniku dr. sc. Claudiju Gnoliju sa Sveučilišta u Paviji čija mi je srdačna pomoć i otvorenost u pojašnjenju ishodišta i primjene klasifikacije integrativnih razina omogućila kvalitetno postuliranje metodologije rada.

Hvala svim knjižničarima, sadašnjim i prošlim, svojim ste radom beskonačno zadužili svijet!

Kada bih krenuo zahvaljivati bratu Marku, nikada ne bih završio.

Hvala ti, Denise Ćutiću, što si vjerno bio Tu. 
Ovaj doktorski rad posvećujem svojim roditeljima, Mariji i Darku. 


\section{SAŽETAK}

Organizacija znanja kao disciplina knjižničarstva i informacijsko-dokumentacijskih znanosti baštini dugu znanstveno-istraživačku i strukovnu tradiciju. U posljednjih 25 godina pojavljuje se niz autora koji $\mathrm{u}$ okviru zagovora multidisciplinarnih, interdisciplinarnih $\mathrm{i}$ transdisciplinarnih pristupa govore o problemu disciplinarne utemeljenosti organizacije znanja. Disciplinarni temelj u organizaciji znanja očigledan je u samim strukturama široko rasprostranjenih sustava za organizaciju znanja poput Univerzalne decimalne klasifikacije. Brojni autori u području takvo zasnivanje organizacije znanja kritiziraju zbog jednodimenzionalnosti tj. monoperspektivnosti, a za njihova alternativna razmatranja karakteristična je evokacija koncepta perspektive i zagovor ideje multi-perspektivistički zasnovane organizacije znanja. Ovaj doktorski rad bavi se osiguranjem jamstva perspektive u transdisciplinarnoj organizaciji znanja i organizacijom znanja $u$ transdisciplinarnim područjima na primjeru integrativne bioetike. Doktorsko istraživanje uključuje deskriptivno bibliometrijsko istraživanje literature u području integrativne bioetike i njenu sadržajnu analizu sa svrhom oblikovanja osnove za izgradnju sustava za organizaciju znanja zasnovanu na klasifikaciji fenomena. Klasifikacija fenomena najprimjerenija je vrsta sustava za osiguranje predmetnog pristupa informacijskim izvorima u području integrativne bioetike jer odgovara njenom zahtjevu za očuvanjem integrativnog pluralizma perspektiva $u$ karakterizaciji bioetičkih fenomena.

Ključne riječi: transdisciplinarnost, organizacija znanja, jamstvo perspektive, integrativna bioetika, pluriperspektivizam, znanje 


\section{EXTENDED ABSTRACT}

\section{Introduction}

This doctoral thesis report on original research employed to organize knowledge and provide documentational support in the field of bioethics. More particularly, this doctoral thesis confronts the problem of perspectival ambiguity in bioethics by considering the notion of perspectives as points of access to diverse outlooks on particular phenomena. Knowledge organization as a discipline of library and information sciences has a long research and professional tradition. In the last 25 years a growing number of authors researching interdisciplinary and transdisciplinary knowledge organization are restating and emphasising the problem of the disciplinary foundations of traditional knowledge organisation systems. These foundations is apparent in the very structures of the most accomplished systems like the Universal Decimal Classification. The critique is focused on the monodimensionality and monoperspectivity of traditional systems, and is characterized by a distinct evocation of the concept of perspectives and advocacy for the development of multi-perspective knowledge organization. According to those authors traditional systems can't respond to the needs of interdisciplinary and transdisciplinary researchers. This doctoral thesis deals with viewpoint warrant in interdisciplinary and transdisciplinary knowledge organization in the context of a specific inter- and transdiscipline of integrative bioethics.

\section{Theoretical background}

The orientation towards perspectival ambiguity in bioethics stemms both from the workplace context of the candidate and the existing developments that aimed to address similar problems in the past. Hence, the thesis is being based specifically in the conceptualization of integrative bioethics (IB) which approaches bioethical topics with intent to integratively preserve the pluralism of perspectives that contribute to a full characterization of different bioethical phenomena i.e. pluriperspectivistically. The task to define a useful way to organize knowledge for such a complex field is supported by the conceptualizations of an interdisciplinary and transdisciplinary knowledge organization (KO) as it was discussed by different authors in the field of KO (Hjørland \& Albrechtsen, 1995; Broughton, 2002; Gnoli, 2012; García Gutiérrez, 2014; Albrechtsen, 2015; Lopez-Huertas, 2015; Szostak, Gnoli \& Lopez-Huertas, 2016). Finally, the thesis considers the recurring evocation of the concept of perspectives in IB and KO (Gnoli, 2012; García Gutiérrez, 2014; Lopez-Huertas, 2015; 
Szostak, Gnoli \& Lopez-Huertas, 2016) and the viewpoint warrant in KO (Beghtol, 2002a) as the third theoretical foundation.

These foundations of the thesis all stem from the critique of the domination of disciplinary perspectives and the idea that we have to address scientific monoperspectivism by representation of how complex our understanding of what we experience can be, which warrants the ability to look at knowledge from a number of different perspectives. However, Szostak, Gnoli \& Lopez-Huertas (2016) stipulated that in order to achieve this one first has to determine how much perspectival ambiguity there is in different studied knowledge domains. The outcomes of the thesis are a contribution to understanding this kind of ambiguity with regard to bioethical phenomena and the complex network of perspectives that contribute to their definition.

\section{Dissertation methodology}

The proposed methodology of the accepted thesis proposal is situated in the methodological paradigm of domain analysis as develped by Hjørland and Albrecthsen (1995) and consists of:

- a conceptual analysis of the concept of viewpoint warrant in order to elaborate its definition in the context of transdisciplinary $\mathrm{KO}$, and in order to map the role of relevant concepts in its definition like: transdisciplinary knowledge, perspectives, knowledge integration, pluriperspectivism etc.;

- a bibliometrical and content analysis of literature in the field of IB to create a prototype system of relationships between studied bioethical phenomena, explored perspectives and characteristics of documents they are affiliated with.

\section{Discussion \& Conclusions}

The thesis shows why ethical issues have potential to be used as a starting point for investigative methodologies that aim to map the perspectival ambiguity surrounding particular (bioethical) phenomena. It is the nature of what is usually named an ethical issue to be problematic and because of this to be subject to diverse reasoning on how to define, interpret and resolve those issues.

In his paper from 2011, Claudio Gnoli, referring to Beghtol, claims that the demand hidden in the viewpoint warrant, constitutes an ethical principle because no single perspective should be 
given priority over alternative perspectives. The notion of integrative bioethics which aims to integratively preserve the pluralism of perspectives that contribute to a full characterization of different bioethical phenomena (i.e. pluriperspectivistically) treats perspectives in the same way. Here goals of IB match those of transdisciplinary KO, since the dialogic interaction of perspectives on ethical issues can only be achieved if we have knowledge about and appreciation of the ambiguity which surrounds them.

The undertaken bibliometrical research has constituted the domain of integrative bioethics as an example of a interdisciplinarly and trandisciplinarily oriented field which formulates a specific request for pluriperspectivistic knowledge organization. Content analysis of articles in the field of integrative bioethics was used to respond to that request and a basis for establishing a knowledge organization system was created in terms of mapping out the relationships between studied bioethical phenomena, explored perspectives and characteristics of documents they are affiliated with.

Keywords: transdisciplinarity, knowledge organization, viewpoint warrant, integrative bioethics, pluriperspectivism, knowledge 


\section{SADRŽAJ}

UVOD

TEORIJSKA OSNOVA DOKTORSKOG ISTRAŽIVANJA ............................................. 4

Povijest klasifikacije i sustava za organizaciju znanja .................................................. 6

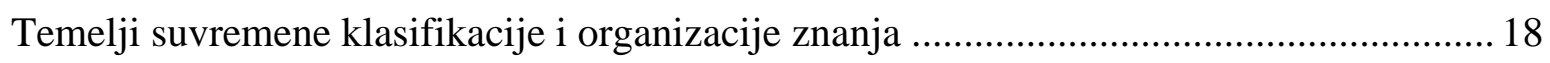

CRG-ove zamjerke i nedostatnosti disciplinarno utemeljenih klasifikacija ...................... 19

Stvaranje nove opće sheme, definicija općih kategorija i teorija integrativnih razina kao

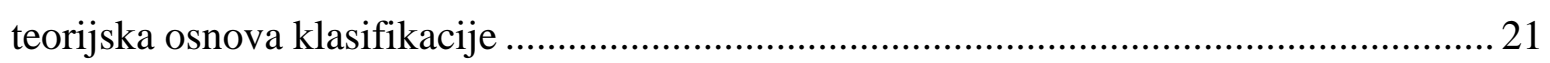

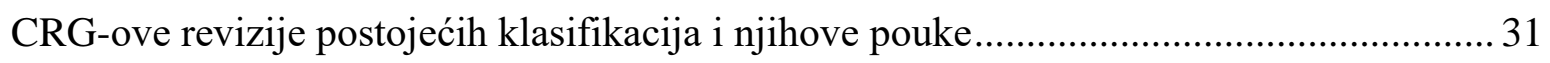

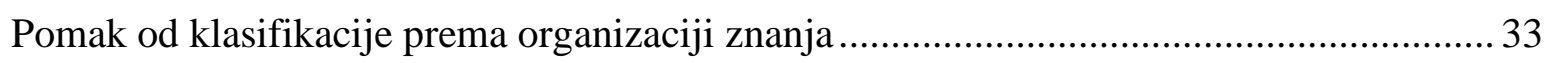

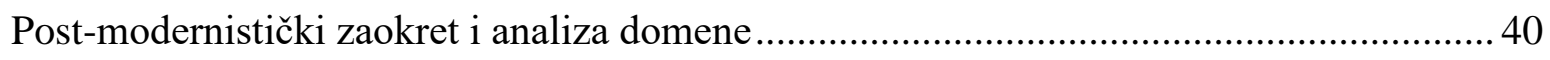

Revitalizacija univerzalizma i kritike disciplinarnosti u organizaciji znanja..................... 44

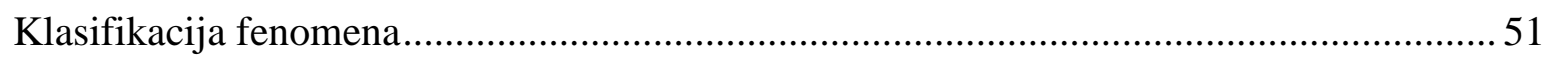

Jamstvo perspektive u interdisciplinarnom i transdisciplinarnom kontekstu..................... 61

Integrativna bioetika i trenutni dosezi osiguranja predmetnog pristupa u bioetici ............. 72

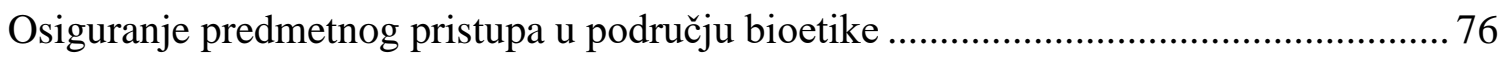

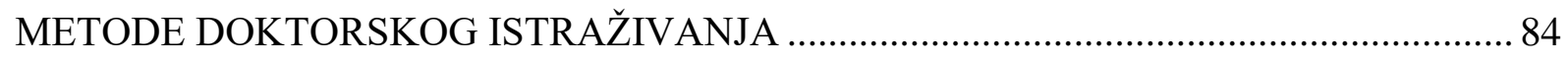

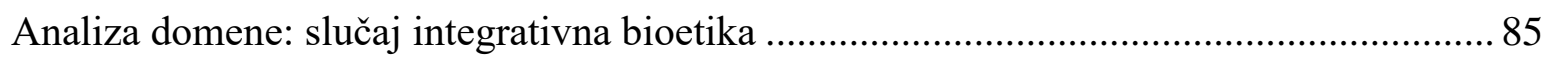

Priprema istraživačkog materijala tj. literature područja integrativne bioetike prema sistemu

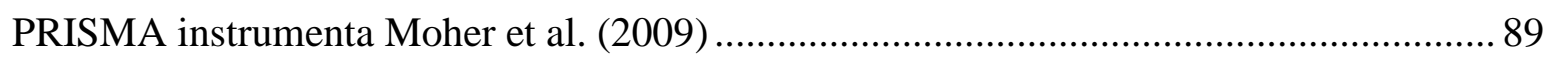

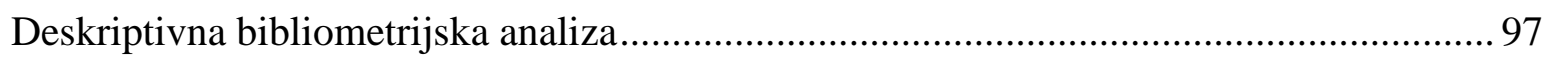

Analiza sadržaja i fasetna analiza literature u području integrativne bioetike .................... 98

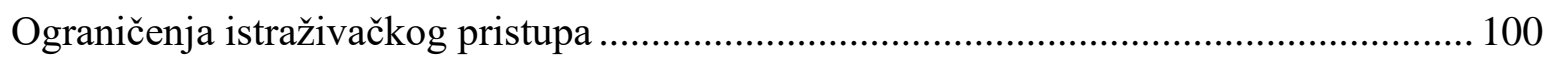

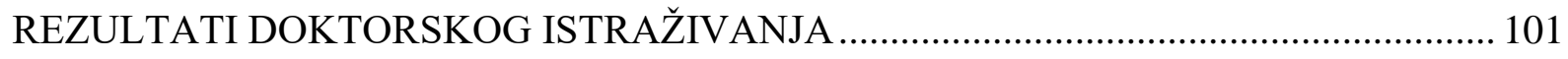

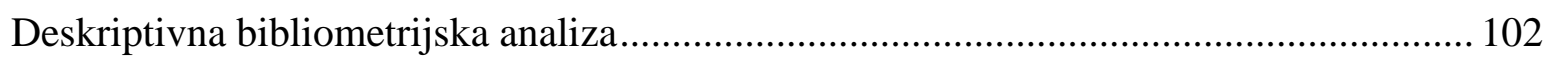

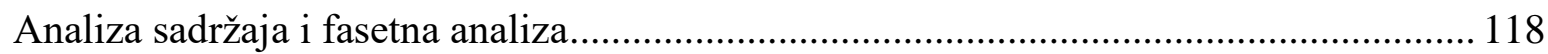




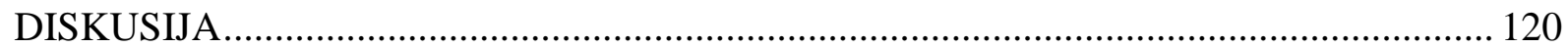

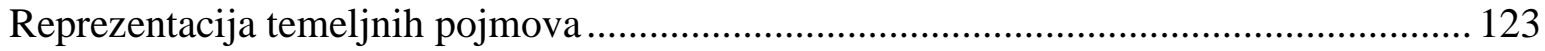

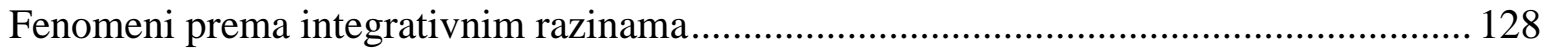

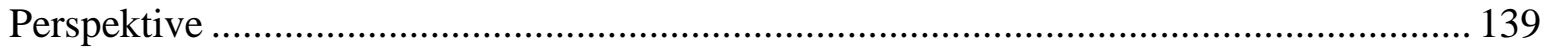

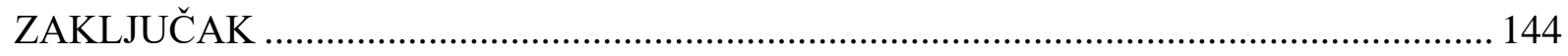

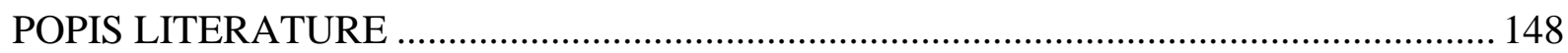

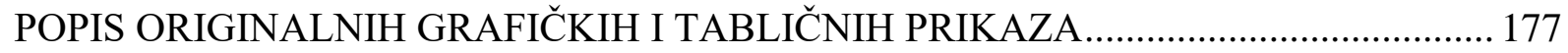

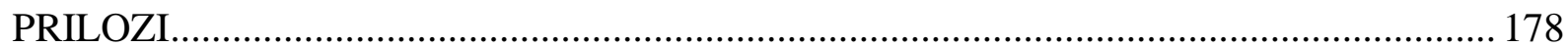

ŽIVOTOPIS AUTORA S POPISOM OBJAVLJENIH DJELA …...................................... 183 


\section{UVOD}

Organizacija znanja kao disciplina knjižničarstva i informacijsko-dokumentacijskih znanosti baštini dugu znanstveno-istraživačku i strukovnu tradiciju. U posljednjih 25 godina pojavljuje se niz autora koji u okviru zagovora multidisciplinarnih, interdisciplinarnih $\mathrm{i}$ transdisciplinarnih pristupa govore o problemu disciplinarne utemeljenosti organizacije znanja. Disciplinarni temelj u organizaciji znanja očigledan je u samim strukturama široko rasprostranjenih sustava za organizaciju znanja poput Univerzalne decimalne klasifikacije. Brojni autori u području takvo zasnivanje organizacije znanja kritiziraju zbog jednodimenzionalnosti tj. monoperspektivnosti, a za njihova alternativna razmatranja karakteristična je evokacija koncepta perspektive i zagovor ideje multi-perspektivistički zasnovane organizacije znanja. Spomenuta jednodimenzionalnost postojećih sustava ne može odgovoriti na suvremene zahtjeve za olakšani pristup znanju u interdisciplinarnim i transdisciplinarnim projektima i područjima istraživanja. Ovaj doktorski rad bavi se osiguranjem jamstva perspektive $u$ interdisciplinarnoj i transdisciplinarnoj organizaciji znanja i organizacijom znanja $u$ interdisciplinarnim i transdisciplinarnim područjima na primjeru integrativne bioetike.

Navedene predmete uzima se kao temelj za istraživanje perspektivističkog zasnivanja organizacije znanja. Prema utjecajnoj definiciji Birgera Hjørlanda (2008, str. 86) organizacija znanja, u užem smislu, „bavi se prirodom i kvalitativnim obilježjima procesa organiziranja znanja, kao i sustava za organizaciju znanja, koji se koriste za organizaciju dokumenata te organizaciju reprezentacija dokumenata, djela $i$ koncepata“. U širem smislu, organizacija znanja bavi se „društvenom podjelom intelektualnog rada, tj. organizacijom sveučilišta $i$ drugih istraživačkih $i$ visokoškolskih institucija, strukturom disciplina i profesija, društvenom organizacijom medija, produkcijom i diseminacijom znanja $i d r . “$ (ibid., str. 86). Uže, specijalizirano i na praktičku aktivnost usmjereno shvaćanje organizacije znanja neodvojivo je od šireg teorijskog razumijevanja. Intelektualna ili kognitivna organizacija znanja neodvojiva je od društvene organizacije znanja. U tradicionalnom pogledu, koji seže sve do 1846. godine i decimalne klasifikacije Melvila Deweya (DDK), zadatak je organizacije znanja reprezentirati poredak prirode iz očišta znanstvene spoznaje, odnosno načina na koji discipline, kao jedinice društvene organizacije znanosti, razotkrivaju i opisuju strukture stvarnosti (ibid.). Područje organizacije znanja doživjelo je mnoge važne konceptualne doprinose kao što su fasetno-analitički pristupi klasifikaciji, tradicija pretraživanja informacija (engl. information retrieval tradition), korisnički pristupi i bibliometrija (ibid.). Izgled 
područja organizacije znanja i projekti koji u njemu nastaju rezultat su trajnog osluškivanja informacijskih potreba u svim društvenim kontekstima u kojima je djelatnost organizacije znanja relevantna i potrebita. Organizacija znanja nalazi se u stadiju reorijentacije, a čak bi vrijedilo reći i promjene paradigme, iz domenski usmjerenih pristupa na pristupe koji modeliraju odnose između većeg broja domena znanja. Ta reorijentacija nije tek odraz neke unutarnje dinamike područja organizacije znanja. Promjene u području o kojima govori ova disertacija odraz su promjena u globalnom informacijskom kontekstu koji postaje saturiran problemima visoke kompleksnosti (npr. globalno zatopljenje, pandemija koronavirusa, glad, zaštita osobnih podataka, istraživanje svemira itsl.) čije razrješenje ne može biti prepušteno niti ostvareno u okvirima pojedinačnih, međusobno izoliranih znanosti ili pak voljom odabranih pojedinaca ili posebnih društveno-političkih interesnih zajednica. Prema Szostaku i suradnicima (2016), interdisciplinarnost postaje nužna i tražena jer se rješenja specijaliziranih eksperata za kompleksne probleme društva prepoznaje kao nedostatne.

Motivacija kandidata za bavljenje temom osiguranja jamstva perspektive u interdisciplinarnoj i transdisciplinarnoj organizaciji znanja proizlazi iz njegovog stvarnog poslovnog konteksta i potrebe znanstvenika i stručnjaka u području integrativne bioetike da mogu identificirati i pronaći znanje zabilježeno u dokumentima s obzirom na perspektivu prema kojoj se predmeti nekog djela razmatraju. Djela za koja je iskazana potreba pristupa takve vrste nalaze se u zbirkama raznovrsnih akademskih i neakademskih dokumenata znanstvenih i stručnih institucija u području bioetike, i specifično, integrativne bioetike.

Ova disertacija sastoji se od pet poglavlja koja prate uvriježenu logiku izvještaja o poduzetom znanstvenom istraživanju. U prvom poglavlju iznosi se teorijska osnova doktorskog istraživanja koja se sastoji u pregledu literature o razvoju područja, a nakon toga i o trenutnim dosezima i ključnim problemskim pitanjima u području klasifikacije i organizacije znanja koja će rad pokušati adresirati. Teorijski dio rada uključuje i konceptualnu analizu pojma jamstva perspektive, s jedne strane u kontekstu područja organizacije znanja i s druge strane u kontekstu integrativne bioetike čiji su koncepti podudarni s idejom jamstva perspektive. U drugom dijelu rada pojašnjena je metodologija istraživanja. Doktorsko istraživanje uključuje deskriptivno bibliometrijsko istraživanje literature u području integrativne bioetike i njenu sadržajnu analizu sa svrhom oblikovanja osnove za izgradnju sustava za organizaciju znanja zasnovanu na klasifikaciji fenomena. Treće poglavlje ima dva dijela te sadrži rezultate doktorskog istraživanja tj. deskriptivnu bibliometrijsku analizu te rezultate analize sadržaja. Četvrto poglavlje sadrži diskusiju o rezultatima i njihovo uparivanje s konceptualnom 
analizom pojma jamstva perspektive koja vodi u peto poglavlje tj. ka zaključku da je klasifikacija fenomena najprimjerenija vrsta sustava za osiguranje predmetnog pristupa informacijskim izvorima u području integrativne bioetike jer odgovara njenom zahtjevu za očuvanjem integrativnog pluralizma perspektiva u karakterizaciji bioetičkih fenomena. 


\section{TEORIJSKA OSNOVA DOKTORSKOG ISTRAŽIVANJA}

Raspravu o konceptu jamstva perspektive koja će se zbiti u okviru ovog doktorskog istraživanja treba odgoditi kako bi se locirala izvorišta te ideje. Koncept jamstva perspektive ne možemo razmatrati bez dubokog uvida u povijest klasifikacije i sustava za organizaciju znanja. Poglavlje o teorijskoj osnovi doktorskog istraživanja sadrži prikaz te povijesti od njenih začetaka $\mathrm{u}$ antičkom dobu pa sve do 20. stoljeća kada započinje proces pretvaranja klasifikacije u visoko strukturirani stručni, a sredinom 20. stoljeća i znanstveni postupak. Za razumijevanje predmetnog koncepta potrebno je objasniti ulogu engleske zajednice znanstvenika tj. Radne grupe za klasifikacijska istraživanja (engl. Classification Research Group i.e. CRG) koja je začela kritičko razmatranje tradicionalnih klasifikacijskih sustava i udarila temelje kritici disciplinarnog utemeljenja sustava za organizaciju znanja kao i alternativu tome pristupu tj. klasifikaciju fenomena.

Prvi dio poglavlja obrađuje zamjerke CRG-a klasifikacijskim shemama utemeljenim na disciplinarnim perspektivama s početka 20. stoljeća, razloge za i okolnosti pokretanja projekata čiji je zajednički cilj bio stvaranje nove opće klasifikacijske sheme te prati rad grupe sve do napuštanja njenih projekata i ideja. S prestankom rada CRG-a grupa preispituje vlastiti fokus na klasifikaciju pa pregled literature uključuje i prikaz pomaka interesa od klasifikacije prema organizaciji znanja koja se konstituira kao novo područje znanstvenog interesa 90-ih godina prošlog stoljeća. S promjenom interesa, dolazi i do postepene promjene paradigme $u$ novoimenovanom području organizacije znanja. Stoga je potrebno objasniti i kontekst postmodernističkog zaokreta i inovaciju analize domene. Konačno, kontekst suvremenih rasprava o klasifikaciji locira se u još jednom paradigmatskom zaokretu tj. kritici postmodernizma i zaokretu prema ideji interdisciplinarne i transdisciplinarne organizacije znanja te revitalizaciji napuštenih univerzalističkih aspiracija u klasifikaciji te projekata izgradnje nove opće klasifikacijske sheme koja bi ovog puta bila utemeljena kao klasifikacija fenomena.

U drugom dijelu poglavlja objašnjava se porijeklo ideje različitih vrsta jamstava koje sustav za organizaciju znanja mora moći osigurati, ideja jamstva perspektive kao etičkog jamstva koje osigurava epistemičku pluralnost sustava za organizaciju znanja te stanje praktičnih dosega za modeliranje jamstva perspektive sa specifičnim naglaskom na klasifikacije fenomena. 
Zaključno, koncept jamstva perspektive objašnjava se u kontekstu inter- i transdisciplinarnosti te se rasprava premješta u područje integrativne bioetike koja se uzima kao primjer jednog interdisciplinarno i transdisciplinarno usmjerenog područja. Poduzima se analiza komplementarnosti integrativne bioetike i organizacije znanja pri čemu je suvremena koncepcija jamstva perspektive kontrastirana idejama integrativne bioetike i konceptu pluriperspektivizma kako bi se objasnile konceptualne podudarnosti područja te utemeljilo integrativnu bioetiku kao jedinstven slučaj čija analiza može doprinijeti konceptualizaciji jamstva perspektive u području organizacije znanja. 


\section{Povijest klasifikacije i sustava za organizaciju znanja}

Jedina ekstenzivna povijest klasifikacije objavljena je na ruskom jeziku i do sada prevedena jedino na njemački jezik (Miksa, 1994¹; Dahlberg, 1976). Napisao ju je E. I. (Evgeniǐ Ivanovich) Shamurin pod naslovom Ocherki Po Istorii Bibiliotechno-Bibliograficheskaia Klassificatsii (engl. The History of Library-Bibliographical Classification, 2 vol., objavljena od 1955. do 1959. godine; njemačka verzija objavljena u razdoblju od 1964. do 1968. godine). Drugim riječima, jedina cjelovita povijest klasifikacije u knjižnično-bibliografskom smislu obuhvaća tek period do 1960. godine. Prije svega potrebno je razjasniti da je složenost prikazivanja povijesnog razvoja klasifikacije uvećana uzme li se kao okosnica prikaza razumijevanje klasifikacije u njenom širem smislu, za razliku od onoga kako se klasifikacija razumije danas u disciplinarnim granicama knjižničnih i informacijskih znanosti. Na temelju te distinkcije moglo bi se uočiti da postoji potreba sastavljanja cjelovite interdisciplinarne i transdisciplinarne povijesti klasifikacije kao neriješenog zadatka u povijesti humanizma, znanosti i društva općenito, no neriješenost toga zadatka samo je prividna. Naime, povijest klasifikacije u širem smislu mogla bi se poistovjetiti s nastojanjima mnogih mislioca da organiziraju čovjekovo razumijevanje cjeline ili dijelova svijeta u kojem živi. Klasifikacijom su se, u tom širem smislu, među prvima bavili filozofi (primjerice već Aristotel razvija klasifikaciju životinjskog svijeta), a iz drugih područja najpoznatiji je vjerojatno klasifikacijski i taksonomijski rad Carla Linnéa, švedskog botaničara i liječnika. Primjeri raznorodnih sustavnih opisa prirode i filozofskih sustava te opisi strukture i logike njihova tvorenja nadilaze namjeru ovog povijesnog prikaza. Ipak, važno je napomenuti da klasifikacije u knjižnično-informacijskom smislu nisu nastale neovisno od razvoja klasifikacije u tom širem smislu. Namjera je ovog povijesnog prikaza ukratko pokazati razvojni put klasifikacije i sustava za organizaciju znanja te objasniti momente u kojima se njihovo poimanje specificira sukladno disciplinarnom razvoju knjižničnih i informacijskih znanosti. Riječima Ingetratut Dahlberg (1976), namjera je ovog povijesnog prikaza pojasniti trenutak u kojem klasifikacija iz umijeća prerasta u znanost.

Prve naznake klasifikacije i sistematične organizacije djela pronalazimo već i u indijskim Vedama, Bibliji i mnogim enciklopedijskim djelima različitih vremenskih perioda (ibid.). U knjižničarskom svijetu prvi oblik kataloga identificira se obično u Kalimahovom (lat.

\footnotetext{
1 Miksin (1994) pokušaj sastavljanja povijesti klasifikacije nije cjelovit u širem smislu te riječi, no autor objašnjava da će se u svome prikazu još i dodatno ograničiti. Enciklopedijsku natuknicu Enciklopedije knjižnične povijesti (engl. Encyclopedia of Library History) o povijesti klasifikacije ograničava na prikaz razvoja univerzalnih hijerarhijskih klasifikacijskih sustava poput DDC-a tj. Deweyjeve decimalne klasifikacije i drugih.
} 
Callimachus, pjesnik i katalogizator Aleksandrijske knjižnice) proznom djelu Popisi (grč.

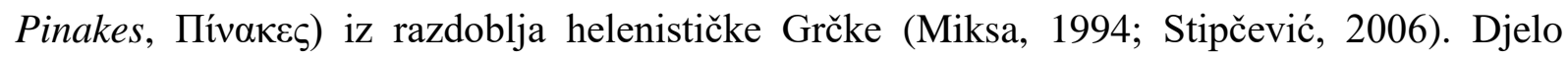
pokazuje da su svitci bili organizirani prema autorima, literarnim formama i drugim temama, a to sugerira njihovu sistematičnu organizaciju prema sadržaju ili pripadnosti nekom području znanja (Miksa, 1994). Prema Stipčeviću (2006, str. 141) ne postoji pouzdani izvor informacija o tematskoj podjeli svitaka, no „nagađa se da su bile raspoređene u deset glavnih stručnih skupina: 1. Pjesme, 2. Drame, 3. Pravo, 4. Filozofija, 5. Povijest, 6. Govorništvo, 7. Medicina, 8. Matematika, 9. Prirodne znanosti, 10. Razno“.

Rimske knjižnice najčešće su nicale u hramovima, a djela su bila organizirana prema jeziku (latinski i grčki), a unutar jezika prema tematici (Miksa, 1994). Tako je i prva javna knjižnica u Rimu smještena u Atrium Libertatis imala dva odvojena odjela za grčke i latinske knjige (Stipčević, 2006).

Miksa (1994) upućuje na to da su ozbiljnije klasifikacije knjiga nastajale u trenutcima kada je bilo potrebno organizirati veće količine dokumenata, a da se u njima zabilježeno znanje pritom tretiralo holistički. Tako spominje primjer Kine gdje su filozofi nastojali kategorizirati fenomene svijeta u kohezivne kategorije (navodi primjere: Devet slojeva raja, Stotinu filozofskih škola, Šest umijeća i dr.). Prvo djelo toga tipa bilo je Sedam epitoma Liua Hsina (a.d. 23) (ibid.). Liu Hsinova shema sastojala se od sekcije sadržaja i sekcija za svaku od šest umijeća - poezija, filozofija, vojno umijeće, znanost, tehnologija i medicina koje su imale i svoje potpodjele (ibid.). Hsinovu shemu zamijenila je shema Chenga Moa, imperijskog knjižničara dinastije Wei (ibid.). Njegova je shema imala četiri područja (klasici, filozofija, povijest i literatura) i zadržala se do modernih vremena (ibid.).

Drugi primjer takvog holističkog pristupa pronalazimo kod islamskih civilizacija koje su klasifikacijske sheme počele aktivnije razvijati tijekom ere visoke kulture od osmog do jedanaestog stoljeća (ibid.). Knjižnice su najčešće bile vezane za džamije, a sistematizirale su i svoje kataloge kao i raspored knjiga na policama (ibid.). Započinjale su Kuranom te pokrivale područja gramatike, povijesti, poezije, prava, filozofije, znanosti i drugih područja. (ibid.).

Kao kontrast takvoj klasifikaciji Miksa (1994) opisuje manje srednjovjekovne knjižnice na zapadu, osnivane najčešće u samostanima čija su djela bila jednostavno podijeljena na sakralnu i sekularnu literaturu. Kako su se zbirke dokumenata povećavale tako se sekularnu 
literaturu počelo dodatno dijeliti prema kategorijama koje su odražavale kurikulume slobodnih umijeća toga doba tj. trivij (gramatika, retorika, logika) i kvadrivij (aritmetika, geometrija, muzika i astronomija) (ibid.).

Od razdoblja renesanse pa sve do sredine 19. stoljeća postavljeni su temelji za razvoj modernih knjižničnih klasifikacija (ibid.). Miksa (1994) ističe kako su se one razvijale zbog društvenih i kulturnih čimbenika, a manje zbog većih napredovanja u klasifikatorskim pristupima knjižničara (ibid.). Karakterizira ih kao pojednostavljene verzije općih shema klasifikacije znanja koje nisu činile značajnu razliku između rasporeda knjiga na policama i zapisa u katalogu (ibid.).

Prema Dahlberg (1976) Angelo Poliziano prvi je autor koji je sistematizaciju znanja vidio kao svrhu po sebi tj. njegova klasifikacija koju je izgradio u svome djelu Panepistemon iz 1491. godine nije služila nekoj prethodno definiranoj praktičnoj svrsi. Njegova je namjera naprosto bila pokazati kako je znanje uređeno u različitim područjima znanosti (ibid.).

Prve korake prema modernom shvaćanju klasifikacije Dahlberg (1976) locira u radu talijanskog filozofa iz 16. stoljeća Maria Nizolia koji je u svome djelu Antibarbarus philosophicus iz 1533. godine kritizirao sheme koje su prikazivale iste znanosti pod više različitih aspekata u cjelokupnoj shemi znanosti. No, tek će fizičar A.-M. Ampère u 19. stoljeću to prepoznati kao narav fenomena koje proučava znanost pa je pred svoju klasifikaciju postavio zadatak da ne reprezentira samo prirodu objekata kojima se znanost bavi, već i gledišta pod kojima se te objekte proučava (ibid.).

U doba renesanse dolazi do procvata znanstvenog mišljenja, širenja sekularnih spoznaja i humanizma pa se ubrzo pojavila potreba da se enumeriraju sva novonastala znanja koja su antičke i klasične metode klasificiranja dovele do svojih granica (Miksa, 1994). U tom razdoblju ističu se Tommaso Campanella koji enumerira kategorije znanja u utopijskom kontekstu te Francis Bacon u djelima Advancement of Learning iz 1605. godine i Novum organum iz 1620. godine (ibid.). Bacon, polazeći od zaključka da je svo ljudsko znanje nastalo djelovanjem triju ljudskih odlika - pamćenja, razuma i mašte - enumerira tri područja kojima te odlike rezultiraju - povijest, filozofija i beletristika (ibid.). Njegova razrađena klasifikacija međusobno povezanog ljudskog znanja, koja ono božansko kategorizira kao produkt ljudskoga, postala je osnova, u pojednostavljenom obliku, za brojne knjižnične kataloge od 17. do 19. stoljeća (ibid.). 
Drugi značajni pomak u tome razdoblju odnosio se na povezivanje holističkog i kohezivnog pristupa univerzumu znanja s obrazovanjem i znanstvenim napretkom (ibid.). Poznat primjer masivne sistematizacije sveg ljudskog znanja u razdoblju prosvjetiteljstva bila je enciklopedija Denisa Diderota i Jeana LeRonda D'Alemberta čiji je cilj bio prikazati sistematske odnose svih grana ljudskog znanja (ibid.). Taj sistematski pristup i koncepcija jedinstva i povezanosti sveg znanja ubrzo je postala i jedno od načela organizacije javnog obrazovanja (ibid.). Štoviše, Miksa (1994) napominje, smatralo se da znanstvena otkrića temeljnih prirodnih zakona možemo izjednačiti s rastom uspostavljenog, sistematski povezanog znanja. Posebna novina ove enciklopedije sastojala se u tome što je nudila uz sistematski i alfabetski način redanja enciklopedijskih natuknica (Dahlberg, 1976).

U 17. stoljeću, zbog proliferacije tiska, razvija se područje bibliografije, a s njime i novi načini popisivanja publikacija (Miksa, 1994). Klasifikacije koje su nastale kao rezultat toga razvoja, također ubrzo pronalaze svoj put do knjižnica, a jedne od zapaženijih razvili su pariški knjižari poput Jacquesa-Charlesa Bruneta (objavljena u djelu Manual du libraire) (ibid.).

Miksa (1994), oslanjajući se na misao filozofa Joséa Ortege y Gasseta, ocjenjuje da je dostupnost knjige osigurala da fenomen knjige postane važan uvjet funkcioniranja društva. Sukladno tome, Miksa (1994) sažimajući ključna uvjerenja o odnosu društva i znanja portretira znanje kao ljudski društveni proizvod koji čini jedinstvenu kohezivnu i međupovezanu cjelinu utvrđenu društvenim procesom intelektualnog otkrivanja novina (dakle, znanošću). Taj se splet ili univerzum znanja, na prijelazu iz 19. u 20. stoljeće počinje shvaćati kao set predmeta ili tema koje su među sobom uređene hijerarhijskim odnosima (ibid.), a nastoji ga se reprezentirati klasifikacijom tako da ona odražava njegovo prirodno uređenje nižući prvo opće i najopsežnije klase ili discipline prema onima sve užeg opsega značenja. Miksa (1994) zaključuje da je sistematičnost u klasifikacijskim odnosima tada postala nužna potreba čovječanstva jer je tako moglo na sistematičan način spoznavati svijet i otkrivati novo znanje.

Prezentaciju moderne povijesti klasifikacije Miksa (1994) dijeli na razdoblje od 1870. do 1920. godine te na razdoblje od 1920. godine do danas.

Osnovica načina organizacije knjiga i informacija bila je dakle temeljena na specifičnoj ideji o ustroju univerzuma znanja. Na temelju toga razumijevanja, uzimajući ga, prema Miksi 
(1994), kao normu i kao najbolji način organizacije za strukovne potrebe, razvijane su knjižnične klasifikacije u modernom smislu.

Nastavak razvoja ideje o ustroju i jedinstvu univerzuma znanja pripisujemo Melvilu Deweyu i Charlesu A. Cutteru koji su pošli od pretpostavke da je za svaku centralnu temu kojom se bavi određeno djelo moguće odrediti istovjetni element univerzuma znanja (ibid.). Organizacija zbirke je prema tome shvaćanju zapravo odražavala samu organizaciju univerzuma znanja, a to je išlo ruku pod ruku sa sistematskim usmjerenjem obrazovnog sustava kojem su knjižnice pružale podršku te je služilo kao pouzdan način pretraživanja sadržaja (ibid.).

U četrdesetim godinama 19. stoljeća dolazi do prevlasti hibridnih sistematskih klasifikacija koje istiskuju dosadašnju praksu alfabetskog redanja knjiga prema sadržaju i autoru (ibid.). Opća praksa postaju tzv. hibridni sindetički pristupi koji kombiniraju elemente sistematske klasifikacije i alfabetskog redanja (ibid.).

Moderne klasifikacije sporo su se razvijale jer još nitko do tada nije pokušao izgraditi opsežnu klasifikaciju (ibid.). Sve su klasifikacije imale oblik jednostavnih shema u Baconovoj ili Brunetovoj tradiciji i nisu tražile svoja uporišta u znanosti već u dotadašnjim filozofskim modelima prilagođenim za praktičnu uporabu u knjižnicama tj. bile su puka stvar knjižnične ekonomije i upravljanja zbirkama (Miksa, 1994; Arboit, 2018). Do prijelaza s 19. na 20. stoljeće razvijeno je pet značajnih univerzalnih knjižničnih klasifikacijskih sustava (Miksa, 1994). Melvil Dewey objavljuje prvo izdanje Decimalne klasifikacije (DDC) 1876. godine koju odlikuje decimalna notacija ${ }^{2}$ i relativni indeks, a temeljena je na zbirci Columbia Collegea u New Yorku (ibid.). Relativni indeks prikazivao je poveznice između predmeta $\mathrm{i}$ disciplina kojima oni pripadaju (ibid.)

Prema Foskettu (1970) važnost doprinosa Melvila Deweyja sastojala se u tome da je koristio znanstvenu metodu kako bi utvrdio kolokaciju predmeta djela te je time omogućio da raspored na policama u knjižnicama ne bude fiksan. Posljedica toga pristupa bile je da se knjižnice mogu započeti baviti baratanjem samim predmetima tj. riječima koje označavaju pojedina djela odnosno oslobodio ih je baratanja samim fizičkim objektima tj. knjigama i drugim dokumentima (ibid.). U organizaciju informacija uveo je, dakle, znanstvenu metodu klasifikacijskih znanosti pomoću prikaza hijerarhijskog odnosa roda i vrste (ibid.).

\footnotetext{
${ }^{2}$ Notacija je sustav oznaka ili simbola (u nekom redoslijedu) koji definira izraze ili članove neke serije ili sustava stvari, a nužan je za očuvanje reda u klasifikacijskim tablicama te za redanje djela na policama prema redoslijedu definiranom logikom sustava notacije (Bliss prema Vickery, 1952).
} 
Uvođenjem decimalne frakcijske notacije mehanizirao je taj postupak i time modernizirao knjižnično poslovanje (ibid.).

Charles A. Cutter 1879. razvija klasifikacijski sustav za bostonsku knjižnicu Athenaeum koju do 1888. godine pretvara u Ekspanzivnu klasifikaciju (EK) ${ }^{3}$ objavljivanu između 1891. i 1893. godine (Miksa, 1994). Godine 1895. dvojica belgijskih odvjetnika Henri LaFontaine i Paul Otlet započinju razvoj klasifikacijske sheme za univerzalnu bibliografiju u kartičnom formatu za potrebe akademske zajednice (ibid.). Na temelju dopuštenja Melvila Deweya da kao osnovu svoje sheme koriste njegovu Decimalnu klasifikaciju 1905. godine objavljuju Manuel de répertoire bibliographique universel) (ibid.). Njihova je shema u svom konačnom obliku bila značajno različita od Decimalne klasifikacije Melvila Deweyja (ibid.). Prvo je bila poznata kao briselska nadopuna, a kasnije pod svojim današnjim nazivom na francuskom jeziku Classification décimal universelle tj. kao Univerzalna decimalna klasifikacija (UDK) ${ }^{4}$ (ibid.). U Americi, James C. Hanson i Charles Martel započeli su razvoj Library of Congress Classification (LCC) tj. Klasifikaciju Kongresne knjižnice (KKK) 1898. godine (ibid.). Do 1911. izdani su zasebni svesci za svaku od glavnih klasa te klasifikacije koje je pratio pothvat reklasifikacije milijunskog fonda Kongresne knjižnice pod vodstvom Herberta Putnama, voditelja Kongresne knjižnice iz toga vremena. James Duff Brown objavljuje Predmetnu klasifikaciju (PK) tj. Subject Classification (SC) 1906. godine, a namjeravala je razriješiti probleme koji su pristizali od praktičara suočenih s izazovima klasifikacije (ibid.).

Prema Miksi (1994) rezultati tih pokušaja bili su sljedeći:

1. enumeriran je iznimno velik broj kategorija znanja do vrlo detaljnih razina specifičnosti;

2. esencijalistički način klasificiranja dorađen je razvojem i klasifikacijom prema nizu ne-esencijalističkih karakteristika dokumenata (npr. prema formi) i sadržaja (npr. prema zastupljenoj filozofiji, metodologiji, povijesti, geografskom ili vremenskom određenju). Neke od tih shema, kao npr. ove potonje postale su standardne potpodjele koje se univerzalno koriste u svim modernim shemama;

3. jezično izražene kategorije zamijenjene su sustavom notacije koji je omogućio da se lokacije knjiga bilježe u sustavima za pretraživanje pa organizacija knjiga više nije

\footnotetext{
${ }^{3}$ engl. Expansive Classification (EC).

${ }^{4} \mathrm{U}$ svijetu je pak najprepoznatljivija na svome engleskom nazivu kao Universal Decimal Classification (UDC).
} 
bila tako strogo vezana za smještaj na polici, a to je pak povratno pospješilo cirkulaciju knjiga;

4. uvedena je ideja notacijske sinteze pri kojoj se moglo kombinirati ne-esencijalističke karakteristike sa simbolima za konceptualne karakteristike.

Prve sheme imale su i svoje probleme (ibid.). Kriterije za određivanje redoslijeda kategorija u shemama nije bilo tako jednostavno odrediti, pogotovo u slučaju klasa na nižim razinama hijerarhije (ibid.). Cutter je kao rješenje toga problema vidio dosljednost $u$ primjeni načela podjele i organizacije klasa oslanjajući se na društvenu i biološku evoluciju tema (ibid.). Za razliku od toga Brownova Predmetna klasifikacija redala je klase na temelju nekoliko prethodno određenih temeljnih koncepata, no to je ponekad dovelo do apsurdnih sekvenci i kolokacija kada se taj princip konzistentno primjenjivao (ibid.). Druge sheme, poput UDK, željeli su poći od nekog načela koje bi bilo praktično, stoga su kretale od konsenzusa stručnjaka o ustroju kategorija znanja, a nakon toga redanje usmjerile prema tom praktičkom kriteriju (ibid.). Kod KKK-a svako predmetno područje moglo je imati vlastito načelo redanja klasa pa je to dovelo do toga da sheme često nisu bile niti sistematične niti konzistentne $\mathrm{u}$ logičkom smislu (ibid.).

Drugi set problema odnosio se na narav predmeta (ibid.). Naime, knjige kao nositelje predmeta nije uvijek bilo lako smjestiti u korespondirajuću kategoriju, a dodatne probleme stvarala je činjenica da knjige često imaju više od jednoga predmeta i mogu pripadati više konceptualnih kategorija istovremeno (ibid.). Taj je problem bio djelomično riješen uvrštavanjem pojedinih aspekata predmeta u jednu od općih kategorija znanja (npr. i muzika i sport imale bi svoje klase za povijest muzike tj. sporta ili filozofiju muzike ili sporta) (ibid.).

Treći set problema odnosio se na to kako očuvati kratkoću notacije da bi signature bile što kraće i korisne u svakodnevnom radu, ali opet ekspresivne u odnosu na ono što se odnose u shemi, a da se u samu shemu stalno mogu dodavati ili udomaćivati (engl. hospitality) novi koncepti (ibid.). Nijedna klasifikacija nije to pitanje dovoljno dobro razriješila i često se moralo dodavati klase koje nisu bile hospitalne ili su imale dugačke notacije. Alternativno, one koje su bile hospitalne i imale kratke notacije gubile su na jednostavnosti i ekspresivnosti (ibid.).

S prolaskom vremena opstale su one klasifikacijske sheme čiji su razvoj podržavale stručne institucije, a preostalo je ključno pitanje hoće li se razvoj klasifikacija usmjeriti dominantno u 
teorijskom ili u praktičnom smislu (ibid.). Prevladali su praktički pristupi, no Miksa (1994) smatra kako je to ograničilo moguće vizije razvoja područja.

Za opstanak klasifikacijskih shema posebno su zaslužni Henri La Fontaine i Paul Otlet koji su 1895. godine osnovali Međunarodnu federaciju za informacije i dokumentaciju ${ }^{5}$ (FID) (engl. International Federation for Information and Documentation) koja je tada djelovala kao Međunarodni institutu za bibliografiju (IIB) (engl. International Institute of Bibliography) (Rayward, 1994). Zadatak Međunarodnog ureda za bibliografiju (OIB) (engl. International Office of Bibliography) osnovanog pri institutu bio je razvoj Univerzalnog bibliografskog repertoara (UBR) (franc. Répertoire bibliographique universel) ${ }^{6}$ (ibid.). Univerzalni bibliografski repertoar bio je univerzalna bibliografija na karticama uređena prema redoslijedu klasifikacijskih predmeta Decimalne klasifikacije Melvila Deweyja (ibid.). Već je spomenuto da je Dewey dao Otletu dopuštenje za korištenje DK za ovu bibliografsku svrhu, a postao je i zamjenik predsjednika instituta (ibid.). Institut je u periodu od 1895. do 1907. godine razvio niz bibliografskih pomagala te je UBR brojao više od 11 milijuna zapisa (ibid.). U rad na UDK bili su u tome periodu uključeni brojni svjetski stručnjaci, a razvijene su pomoćne tablice te pravila za slaganje složenih brojeva koja i danas čine osnovu te klasifikacije (ibid.). Do 1907. godine UDK je bio objavljen na više od 2000 stranica (ibid.).

Intelektualni predvodnici ovog razdoblja, poput Cuttera i Blissa, smatrali su da bibliografska klasifikacija mora biti utemeljena na klasifikaciji znanstvenog znanja (Arboit, 2018). Drugim riječima, tada se utvrđuje dvostruka svrha klasifikacije koja će područje pratiti sve do danas. S jedne strane, o klasifikacijama govorimo istovremeno kao o konceptualnim sustavima koji prikazuju filozofsko mišljenje i strukturu znanstvenog znanja, a s druge strane one istovremeno mogu biti bibliografski sustavi čiji je cilj omogućiti upravljanje konkretnim fizičkim zbirkama koje se nalaze u knjižnici (ibid.). Dominantno razumijevanje svrhe klasifikacije toga doba bilo je da ona mora poštovati prirodni poredak u obliku kakvom ga je otkrila znanost tj. tretira ga kao ideal koji klasifikacije namijenjene za redanje knjiga moraju slijediti (ibid.). Takav pogled razotkriva pozitivističku orijentaciju tadašnjih tvoritelja klasifikacijskih sustava jer je prema njima proces tvorenja znanstvenog znanja savršen i neupitan proces uspostavljanja stabilnog i evolucionarnog napretka znanstvenog znanja (ibid.).

\footnotetext{
${ }^{5}$ Prva promjena naziva dogodila 1937. godine kada institut postaje Međunarodna federacija za dokumentaciju (franc. Federation internationale de documentation), a dodatak koncepta informacija dogodit će se tek 1988. godine (Horton, 2009).

${ }^{6}$ engl. Universal Bibliographic Repertory.
} 
U posljednjem periodu nakon 1920. godine ključnu ulogu u razvoju UDK imali su Frits Donker Duyvis, Henry E. Bliss i S. R. Ranganathan (Miksa, 1994; Rayward, 1994). U ovome periodu UDK počinje dominirati nad drugim vrstama klasifikacija na svjetskoj razini jer jedina ima razvijene sintetičke notacijske tehnike za upućivanje na višesložne i kompleksne kombinacije predmeta u dokumentima (Miksa, 1994). U narednom periodu Bliss i Ranganathan razvit će novu teorijsku osnovu UDK (ibid.). Bliss objavljuje dva djela: The classification of knowledge and the system of the sciences (1929) i djelo The organization of knowledge in libraries (1933), a nakon toga ponudio je vlastiti klasifikacijski sustav Bibliografska klasifikacija (BK) (engl. Bibliographic classification (BC)) (ibid.). Ranganathan je 1933. godine razvio svoju kolonsku klasifikaciju ili Klasifikaciju s dvotočkom (engl. Colon classification (CC)) i objasnio je u više svezaka od kojih je najobuhvatnije djelo Prolegomena to Library Classification (1937) (ibid.). Njihovi su se pristupi ponovno zasnivali na ideji kohezivnog univerzuma znanja, a Bliss je svoju shemu zasnovao na kriteriju gradacije po specijalnosti (ibid.).

Ranganathan, otac moderne klasifikacijske teorije (Dahlberg, 1976), kao matematičar pošao je od njemu poznatih teorija pa je tako razmatrao univerzum predmeta kao nebrojive skupove beskonačnosti predmeta koje je trebalo pokušati pretvoriti u linearni red notacije (Miksa, 1994). Ti skupovi beskonačnosti ponašali su se kao obitelji ili kategorije karakteristika predmeta koje su činile cjeline te kojima je bilo moguće dodijeliti vlastite notacije (ibid.). Kombinirajući notacije klasično shvaćenih predmeta s notacijama skupova karakteristika postalo je moguće izražavati kompleksne predmete (ibid.). Time je po prvi puta jedan prikaz univerzuma znanja ${ }^{7}$ postao adekvatan da prikaže opseg kompleksnosti predmetnih odnosa sadržanih u dokumentima (ibid.). Za njega je klasifikacija znanost koja ima svoja načela, teoriju i metodu (Foskett, 1959; Arboit, 2018). Dahlberg (1976) objašnjava da Ranganathanova matematizacija klasifikacije nije bila kvantitativna ili statistička već kvalitativna tj. da je tražio konceptni jezik kako bi mogao izraziti bilo koji koncept ili predmet koji postoji u svijetu. Kategorije koje Ranganathan razrađuje tzv. analitičko-sintetičkim pristupom zovemo fasetnim ${ }^{8}$ kategorijama, a proces njihove identifikacije fasetnom analizom

\footnotetext{
${ }^{7}$ Pojam univerzuma znanja kod Ranganathana definira se kao dinamički, promjenjiv kontinuum koji opisuje određenu koncepciju postojećih struktura sveg ljudskog znanja (Vickery, 1954). Čini ga univerzum entiteta (tj. skup konkretnih i konceptualnih egzistencija). Svaki entitet ima neke karakteristike prema kojima je moguće razdjeliti univerzum znanja u zasebne grupe ili klase. Intencija je njegova rada bila stvoriti opću teoriju klasifikacije na temelju komparativnih studija klasifikacijskih sustava (Foskett, 1959). Vidi više u Ranganathanovom djelu Prolegomene za knjižničnu klasifikaciju (1937).

${ }^{8}$ Definicija fasete opće je mjesto u području organizacije znanja. Klasifikacijske sheme koje ih koriste zovemo fasetnim klasifikacijama (Cleverdon, 1960). Fasetne sheme su one sheme koje kategorije predmeta definiraju na
} 
(Miksa, 1994). Fasete su bile osnova njegove Klasifikacije s dvotočkom (ibid.). Njene tabele sadržavale su osnovne predmete i fasetizirane izolate - izolirane karakteristike predmeta (ibid.). Za te fasete proglasio je P.M.E.S.T. red tj. način navođenja $\mathrm{i}$ redanja faseta $\mathrm{u}$ produciranim oznakama (ibid.). P.M.E.S.T. - Personality, Matter, Energy, Space, Time ${ }^{9}$ - bio je aksiomatski i kanonski kod i propis procedure kojim se trebalo voditi u korištenju njegove tehnike klasificiranja (ibid.). Time je omogućeno da se notacija može pročitati s obzirom na jezične predmetne kategorije koje su notacije odražavale (ibid.). Dokument je za njega značio bilo koju količinu teksta te se njegova klasifikacija mogla primijeniti na bilo kojoj dubini tj. razini granularnosti dokumenta - tzv. duboki način klasificiranja, duboka klasifikacija ili klasifikacija dubine koja omogućuje pristup predmetima zakopanim negdje u tekstu dokumenta (ibid.). Ranganathanovim posebnim doprinosom teoriji klasifikacije smatra se njegova podjela razina na kojima se klasifikacija zbiva: idejni (prostor ideja i koncepata), verbalni (prostor verbalnih iskaza koncepata ovisnih o jeziku) i notacijski prostor (prostor fiksiranja postojećih koncepata apstraktnim formama poput znakova kao što slova i brojevi) (Dahlberg, 1976).

Ranganathanovi fasetno-analitički pristupi predstavljaju zaokret i u epistemološkom smislu. Naime, za njega znanje nije neka stabilna kategorija pa je smatrao da su modeli znanja koje razvijaju filozofi i znanstvenici neka vrsta mentalne igre za njihove tvorce tj. da im društvena svrha prijenosa znanja nije primarni interes (Arboit, 2018). Prema Arboit (2018), kod Ranganathana zamjećujemo prve naznake kognitivističkog pristupa klasifikaciji. Naime, njegova su objašnjenja i teorije prožete idejama o funkcioniranju mehanizama i ljudskih mentalnih procesa (ibid.). Spomenute razine, na kojima definira da se klasifikacija zbiva, pokazatelj su njegova razumijevanja klasifikacije kao nečega što se bavi idejama potpuno neovisnim od jezika i pojmljivim isključivo u individualnoj svijesti čovjeka (ibid.). To ga istovremeno čini i pobornikom idealističkog pristupa (ibid.) koji će redefiniran kao potraga za

temelju pojedine karakteristike predmeta. Klasifikacija nekog područja ne može se zadovoljiti taksonomijskim popisom koncepata čiji oblik odgovara onom uvriježenom ili najuobičajenijem već klasificiranje zahtijeva da se koncepte određuje i u odnosu na njihova svojstva, ponašanja, interakcije i postupke u kojima sudjeluju (Vickery, 1962). Zbog toga pojedina shema može sadržavati nekoliko zasebnih hijerarhija u kojem sudjeluju isti koncepti. Fasetna analiza i fasetna reprezentacija omogućuju ekonomičnije strukturiranje tih hijerarhija tj. faseta. Prema Vickeryju (1962) fasetna analiza zapravo je konceptualna analiza predmeta koja rezultira odabirom hijerarhije tj. skupa karakteristika tj. fasete, iz teorijski neomeđenog broja karakteristika, kao one koju klasifikator smatra najznačajnijom za proučavanje i primjenu pojedinog predmeta.

${ }^{9}$ Praksa klasifikacije često polazi od popisa tzv. fundamentalnih kategorija, odnosno kategorija koje se često pojavljuju kod pojedinih predmeta (Vickery, 1962). Ranganathanova P.M.E.S.T. formula primjer je takvog popisa fundamentalnih kategorija ili faseta. 
univerzalnim konceptima i univerzalnom klasifikacijom ostati jedan od temeljnih teorijskih pitanja područja klasifikacije sve do danas.

Tijekom razdoblja Drugog svjetskog rata rad na klasifikacijama usporen je, a FID se okreće umrežavanju s drugim međunarodnim udruženjima (UNESCO, IFLA), razvoju i proširenju ideje internacionalizma te novim potrebama poput informacijskog menadžmenta, informacijskih usluga i informacijske analize (Rayward, 1994). Značajno je i istaknuti da je fasetna analiza imala izrazit utjecaj pa su tako i DDK (1965.-1989.) i UDK (1948.-1985.) revidirane prema tom principu sredinom druge polovice 20. stoljeća (Miksa, 1994; Dahlberg, 1971). U drugoj polovici 20. stoljeća gotovo sve klasifikacijske sheme uključivale su fasetne pristupe (Miksa, 1994).

Danas nema sumnje da su DDK i UDK internacionalno prihvaćene sheme koje se primjenjuju diljem svijeta na oko 30 svjetskih jezika (ibid.). U kontekstu te internacionalizacije postalo je jasno da knjižnični klasifikacijski sustavi izražavaju kulturne i političke potrebe, orijentacije i svjetonazore, a posebice je to bilo vidljivo u shemama islamskih i kineskih zemalja (ibid.).

Nakon rata rađa se nova fronta inspirirana Ranganathanovim pristupima. Skupina engleskih znanstvenika organizira se u tzv. Radnu grupu za klasifikacijska istraživanja (engl. Classification Research Group $)^{10}$ koja kao svoj cilj postavlja pokušaj stvaranja novog univerzalnog klasifikacijskog sustava i začetak kontinuiranog istraživačkog razmatranja klasifikacije. CRG-ovi članovi od početaka se slažu u dvije točke. Prvoj, da su svi postojeći klasifikacijski sustavi nezadovoljavajući i drugoj, da bi sistematska organizacija dokumenata prema predmetu mogla biti ključna za razvoj uspješnih sustava za pretraživanje informacija. Mišljenje o tome da je promjena nužna nije u doba začetka rada ove skupine bila neka novina, već kulminacija nedostataka tradicionalnih sustava čija se teorijska osnova nije bitno mijenjala od osamnaestog stoljeća (Vickery, 1952).

Rad znanstvenika i stručnjaka na razvoju klasifikacije i rad CRG-a najbolje se može pratiti pomoću niza specijalnih $C R G$ biltena (engl. CRG Bulletin) koje grupa objavljuje kako bi informirala stručnu javnost zainteresiranu za pomake u teoriji i praksi klasifikacije (1955a, 1956, 1957, 1958, 1961, 1962, 1964, 1968, 1973, 1978, 1985) te kroz seriju znanstvenih skupova koji su se održavali od 1957. godine pod nazivom Međunarodna studijska

\footnotetext{
${ }^{10}$ Više o začecima vidi u Foskett, D. (1962). The classification research group 1952-1962. Libri, 12(4).
} 
konferencija o klasifikacijskim istraživanjima ${ }^{11}$ (engl. International study conference on classification research).

Kraj prošlog tisućljeća donio je i nove izazove. Pojavljuje se računalo i započinje proces kompjuterizacije pa se postavlja pitanje može li procesuiranje prirodnoga jezika zamijeniti klasifikacije (Miksa, 1994). Šezdesetih i sedamdesetih godina interes se usmjerava na prirodu jezika za indeksiranje i terminologije, razvijaju se neke nove vrste sustava (npr. tezaurusi), a interes se značajno usmjerava na zadovoljenje potreba mrežnog okruženja i informacijskih sustava koji su postali dostupni preko mreže (npr. OPAC) (ibid.). Klasifikacije poput DDC-a prevode se na strojno-čitljive formate (ibid.). Rad na UDK intenzivnije se nastavlja od 1992. godine kada vlasništvo UDK od FID-a preuzima specijalno osnovani konzorcij. UDK konzorcij 1993. godine na temelju verzije UDK razvijene pod Duyvisovim vodstvom stvara prvu bazu podataka koja sadrži UDK tabele u računalnom obliku te ga bez značajnih promjena u teorijskim osnovama postavljenim tijekom 20. stoljeća nastavlja proširivati i uređivati njegove tabele sve do danas (UDCC, 2021). FID je djelovao sve do kraja 2000. godine kada će se zbog organizacijskih i financijskih problema ukinuti i prestati sa svojim djelovanjem (Horton, 2009).

\footnotetext{
${ }^{11}$ Alan Gilchrist 1997. godine, četrdeset godina nakon prve konferencije u Dorkingu, kao urednik u zborniku radova šeste u nizu spomenutih konferencija okuplja i objavljuje reminiscencije ključnih imena u području klasifikacije na tu prvu konferenciju u Dorkingu. Govori se o Dorkingovom nasljedstvu kao prekretnici u suvremenim klasifikacijskim istraživanjima, no mnogi sudionici izražavaju brigu ili razočarenje što se u području polaže previše nade u računalna rješenja i automatizacijske pristupe klasifikaciji.
} 


\section{Temelji suvremene klasifikacije i organizacije znanja}

Za potrebe ove disertacije posebnu pozornost treba posvetiti radu spomenute Grupe za klasifikacijska istraživanja. Naime, upravo je CRG u drugoj polovici 20. stoljeća prošlog tisućljeća nastavio teorijska promišljanja klasifikacije dominirajući u razdoblju koje se ponekad naziva i zlatnim dobom klasifikacije, a nakon toga ta će uloga pripasti Međunarodnom udruženju za organizaciju znanja (ISKO, engl. International society for knowledge organization). CRG je već sedamdesetih godina prošlog stoljeća uvidio da perspektiva razvoja područja leži u interdisciplinarnoj i transdisciplinarnoj suradnji, iako će ta perspektiva zaživjeti tek u proteklih dvadesetak godina. Spomenuto zlatno doba klasifikacije primarno je obilježeno kritikom tradicionalnih klasifikacijskih sustava koja će zamrijeti početkom devedesetih godina i biti revitalizirana početkom novog tisućljeća. Ovo će razdoblje obilježiti i smjena paradigmi pa će tako klasifikacija postati tek jedan od dominantnih oblika organizacije znanja, a sama organizacija znanja postat će novi termin koji će okupljati zainteresirane znanstvenike i stručnjake.

Rad CRG-a započeo je 1952. godine raspravama o osnovnim principima klasifikacije čiji zaključak bio da fasetni pristupi trebaju biti osnova svih klasifikacijskih sustava (Foskett, 1962). Činili su ga pretežito članovi iz Ujedinjenog Kraljevstva, no grupa je ubrzo postala internacionalna. Sve članove, sudeći prema izdanim memorandumima, odlikovalo je stajalište da ne podržavaju niti promoviraju niti jednu specifičnu klasifikacijsku shemu te da ne postoji potreba da se UDK a priori prihvati kao najbolji klasifikacijski alat zbog njene rasprostranjenosti i stupnja razvijenosti (CRG, 1955a).

Ultimativno poslanje CRG-a bilo je odgovoriti na pitanje o tome kakva nam je klasifikacija uopće potrebna. Pritom grupa ulazi u najdetaljnija pitanja dizajna i strukture klasifikacijskih shema (o naravi notacije, potrebi i načinu hijerarhijskog prikaza, potrebi za operatorima koji uparuju predmete, potrebi i redoslijedu faseta, opsegu pojedinačnih shema i razini njihove specijalizacije, općenite svrhe sheme i dr.), no tri su najdominantnija područja rasprave:

1. Pitanje nedostatnosti disciplinarno utemeljenih klasifikacija

2. Pitanje stvaranja nove opće sheme, općih kategorija i teorije integrativnih razina kao teorijske osnove klasifikacije

3. Pitanja revizije postojećih klasifikacija i pouka koje donose za razrješenje prethodnih pitanja 


\section{CRG-ove zamjerke i nedostatnosti disciplinarno utemeljenih klasifikacija}

Kritike nedostatnosti postojećih, disciplinarno utemeljenih klasifikacija polazile su od uvjerenja da ti sustavi nisu dovoljno učinkovit alat za prijevod seta termina (prirodnog jezika), pomoću kojih je neka informacijska potreba izražena, na strukovni jezik kojim je neki skup odgovarajućih dokumenata opisan u datom sustavu organizacije (Foskett, 1962).

Godine 1955. CRG izdaje memorandum o trenutnim dosezima u području klasifikacije pod naslovom The need for a faceted classification as the basis of all methods of information retrieval (cf. CRG, 1955b). Rad prikazuje da je Ranganathanova fasetna analiza objeručke prihvaćena, no postignut je načelni konsenzus da se predmeti ne bi trebali nasilno uvrštavati u prethodno i na umjetan način definirane kategorije (Foskett, 1962). Zbog toga CRG odustaje od dosljednog praćenja Ranganathanove P.M.E.S.T. ${ }^{12}$ (Personality, Matter, Energy, Space, Time) fasetne formule (ibid.).

U spomenutome je memorandumu upečatljiva kritika postojećih sustava koju CRG razrađuje u 10 točaka tj. ,....kako slijedi:

\section{Tablice nisu dovoljno detaljne.}

2. Procesi revizija i proširivanja su prespori.

3. Postoji neslaganje o točnom smještaju predmeta u shemama.

4. Mnoge su klase heterogena mješavina neznatno srodnih predmeta.

5. Pojavljivanje istih predmeta $u$ više od jedne klase nije razriješeno na zadovoljavajuć način.

6. Teško je uvesti fenomene nerazjašnjenih relacija s postojećim znanjem.

7. Teško je uvesti nove klase znanja koje su se razvile od novih fenomena ili razvojem postojećih klasa.

8. Odnosi među klasama su iskrivljeni.

\footnotetext{
12 Odbacivanje ove formule rezultat je rasprava o načinu definiranja i oblikovanja glavnih klasa $u$ općim klasifikacijskim shemama. Naime, prema Ranganathanovom objašnjenju kategorija Osobnost (engl. Personality) i kategorija Materija (engl. Matter) ponekad su se koristile naizmjenično tj. isti se predmeti mogu naći u poziciji da unutar određene klase budu smatrani Osobnošću tj. onim centralnim predmetom klase (Foskett, 1978). Tako npr. stolac kao osobnost možemo dodatno odrediti materijom od koje je sačinjen npr. drvo ili čelik, dok drvo ili čelik mogu biti smatrani osobnošću tj. centralnim predmetom u području/klasi metalurgija (ibid.). Dakle, materijali nisu jednoznačno definirani kao vrsta materije is am je Ranganathan tražio neki objektivni način rješenja tog problema (ibid.).
} 
9. Klasifikacijske sheme čine rigidno specificiranu mrežu koja vodi do rigidno grupiranih skupina predmeta.

10. Notacijska reprezentacija ponekad je kompleksna, zbunjujuća, duga i teško pamtljiva. "(CRG, 1955b, str. 6).

Uz navedeno, posebno je elaborirano da temeljni odnos rod-vrsta (lat. genus-species) na koji su se dotadašnji sustavi ograničavali nije dostatan za izražavanje kompleksnih odnosa između ideja koje dokumenti mogu sadržavati te da bi bilo potrebno osmisliti sustave koji bi omogućili izražavanje tih dotada zanemarivanih vrsta odnosa (Foskett, 1962). Coates (prema ibid.) produbljuje taj zaključak i pokazuje da odnos rod-vrsta ograničava tvorbu notacija koje će postati kraće i općenitije ako se kao njihov temelj uzme neki drugi oblik redanja ili smisao podjele. Austin (1974) sumira dotadašnju kritiku te kao probleme navodi nedovoljnu specifičnost shema, njihovu zastarjelost, njihovu neprilagođenost strojnoj manipulaciji i eksploataciji te nemogućnost uvrštavanja novih koncepata bez značajnih posljedica. U onim pak slučajevima kada se nastoji inovirati u postojeće sheme postupak te inovacije izrazito je nepredvidljiv (ibid.).

Problem s tradicionalnim klasifikacijama sastoji se i u tome da nisu u svoj razvoj uvrstile napredak same znanstvene metode pa tako nisu uspjele reprezentirati odnose koji su se s vremenom uspostavili s razvojem pojedinih znanstvenih područja (Foskett, 1970) (a kasnije ćemo vidjeti da nisu u potpunosti primjerene za reprezentaciju predmeta nastalih interakcijom različitih znanosti kao ni predmeta nastalih na temelju interakcije znanstvenih i neznanstvenih modaliteta mišljenja). Foskett (1970) ističe da su sami predmeti počeli biti tretirani kao objekti pa su stvarane hijerarhije predmeta koje ne odražavaju stvarne odnose roda i vrste već imaju praktičku funkciju korisnog, ali arbitrarnog združivanja predmeta. Zbog toga, navodi, klasifikator mora literaturu prilagoditi klasifikacijskoj shemi, a ne obrnuto (ibid.). Zaključuje da se granice disciplina zamućuju, a to je pogotovo vidljivo u društvenim znanostima te zbog toga smatra da je potrebna opća shema tj. neki opći indeksni jezik za kontrolu informacija kako bi se razradila sistematična struktura cjeline sveg znanja (ibid.) 


\section{Stvaranje nove opće sheme, definicija općih kategorija i teorija integrativnih razina kao teorijska osnova klasifikacije}

Iza 1962. godine prošlog stoljeća rad CRG-a počinje se prirodno strukturirati (načelno u tri prethodno spomenuta područja djelovanja) jer se pojavljuje niz projekata na kojima su članovi angažirani u sklopu svojih redovnih poslovnih angažmana te je stoga moguće kontinuirano pratiti njihov razvoj kroz CRG Biltene sve do devedesetih godina.

Svoj rad u prvih desetak godina djelovanja CRG okrunjuje izdavanjem priručnika o fasetnoj klasifikaciji u specijalnim shemama (Foskett, 1962). Ponukani tim iskustvima i reflektirajući nad nedostacima postojećih shema CRG počinje propitivati postoji li potreba za izgradnjom nove opće sheme te pitanje njenog eventualnog odnosa sa specijalnim shemama (ibid.). Potrebu za općom klasifikacijom počeli su naglašavati i sami izrađivači specijalnih klasifikacija na koju bi se njihovi proizvodi mogli osloniti. Razmatra se mogućnost integracije većeg broja specijalnih shema, no na kraju se zaključuje da se opća shema mora ipak temeljiti na nekom transcendirajućem pristupu koji određuje njenu strukturu, čak i ako to dovede do toga da svaka specijalna shema koja se želi temeljiti na općoj shemi mora preurediti neke aspekte opće sheme za svoje potrebe (kao npr. redoslijed faseta i pod-faseta) (CRG, 1961; 1964). CRG (1961) oblikuje mišljenje da će zadatak izrade opće sheme tražiti da se specijalisti privremeno reorijentiraju na opći pogled dok bi tek samo neke jedinstvenosti specijalističkog predmetnog područja ostale prisutne u općoj shemi ${ }^{13}$. Foskett (1970) objašnjava da nam je pri primjeni fasetne analize na specijalne predmete poznato od kuda treba krenuti. Počinje se od literature o samome predmetu i na temelju nje stvaramo shemu za sve termine koji se u njoj pojavljuju (ibid.). Prema njemu važno je odrediti granice discipline te smatra da na to pitanje ne možemo izbjeći ponuditi nekakav odgovor (ibid.).

Foskett $(1962$; 1970) ističe da je autorica Barbara Kyle bila prva koja je odustala od tradicionalnih disciplina. Zbog toga je rad CRG-a na općoj shemi započeo upravo razmatranjem njene klasifikacije društvenih znanosti koja okuplja nekoliko različitih područja

\footnotetext{
${ }^{13}$ Problem tvorenja opće klasifikacije od specijalnih Vickery (1692) objašnjava na primjeru aeronautike. U području aeronautike nećemo moći stvoriti klasifikaciju koja će obuhvaćati samo temeljne ili centralne predmete poput zrakoplova, dijelova zrakoplova i njihove strukture itd. već je potrebno definirati i pomoćne fasete kao što su npr. materijali za izradu dijelova zrakoplova, načine produkcije tih materijala i njihove fizičke karakteristike itd. Na tome primjeru jasno je da fasete koje su pomoćne u jednome području mogu biti centralne fasete nekog drugog područja (npr. fizike). Upravo zbog toga što se u konstrukciji specijalnih klasifikacija daje prednost jednim predmetima i skupovima karakteristika nad drugima nije moguće stvoriti opću klasifikaciju združivanjem većeg broja specijalnih klasifikacija. Općenitija klasifikacija koja bi se primjerice ticala znanosti i tehnologije u cjelini nužno traži redefiniciju fokusa, odabir ključnih predmeta i skupova karakteristika sukladno novom, općenitijem usmjerenju sheme.
} 
pa time nije klasična specijalna klasifikacija. Njena je specifičnost odstupanje od kanonske podjele glavnih klasa društvenih znanosti kako bi se omogućilo uvođenje poretka koji prati strukturu novih teorijskih pristupa (Foskett, 1962). Tako klasifikacija Barbare Kyle primjerice omogućuje da se predmeti, ako postoji sklonost klasifikatora određenom teorijskom tumačenju, iskazuju s obzirom na prirodu društvenih grupa ili društvenih zakona za razliku od dotadašnjih individualističkih pristupa koji tvrde da se grupe ne može smatrati stvarnim, u svijetu postojećim, entitetima (Foskett, 1962; cf. Kyle, 1958). Takav pristup jedan je od, do tada, rijetkih slučajeva gdje se u klasifikaciji naglašava uloga gledišta s kojeg neki predmet biva razmatran, a pojavljuje se zbog mišljenja eksperata da različitost gledišta nije adekvatno reprezentirana u postojećim sustavima za organizaciju znanja.

Vidljivo je već i kod Kyle da se CRG uvijek vraćao na temeljno pitanje o najboljem principu podjele poznatog univerzuma znanja (ibid.). Od samih početaka grupa je razmatrala razine integracije kao jedan od mogućih principa. Sama teorija, pod nazivom teorija integrativnih razina, dolazi od autora J. K. Fieblemana i Josepha Needhama, a Foskett (1962; Spitteri, 1995) interpretira da se prema toj teoriji sve stvari u svijetu razvijaju od jednostavnih prema složenima akumulacijom novih i divergentnih karakteristika zbog čega ponekad dolazi do transformacije samog entiteta čime on prestaje biti član trenutne grupe i postaje član neke nove grupe entiteta. Drugim riječima, svaki cijeli entitet više je od sume svojih dijelova ${ }^{14}$ (Foskett, 1978). Takav model kreira piramidalnu strukturu pri čemu najviše razine imaju najmanju populaciju instanci (CRG, 1964; Foskett, 1978).

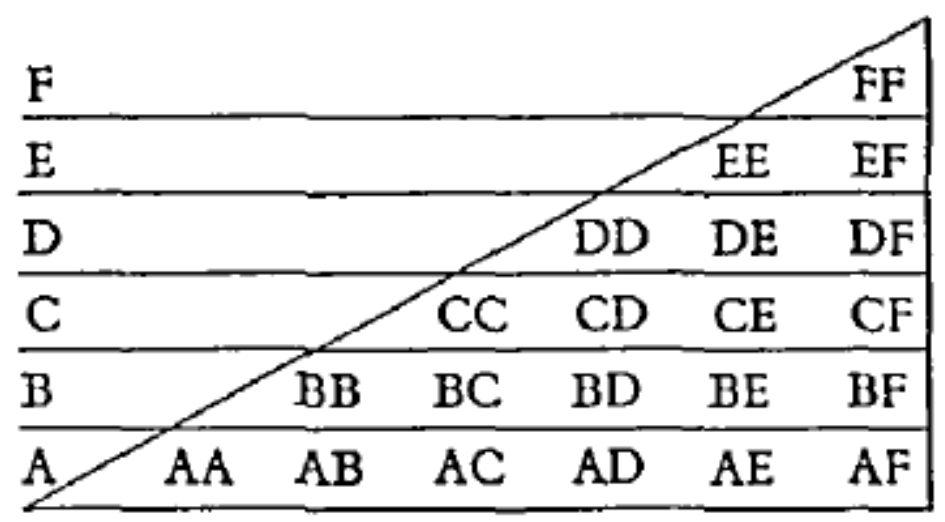

Slika 1. Piramidalna struktura integrativnih razina u teoriji integrativnih razina (CRG, 1964)

\footnotetext{
${ }^{14}$ Foskett (1978) nudi primjer bicikla i čovjeka. Bicikl je više od skupa svojih dijelova jer samo ukoliko su ti dijelovi organizirani na vrlo određen način i postavljeni u određeni set odnosa te samo ako su sačinjeni od određenih materijala možemo govoriti o entitetu bicikl. Ljudi su manje ili više sačinjeni od istog skupa kemijskih i bioloških materijala, no svaka je osoba jedinstvena zbog njenog međuodnosa s okolinom oblikovanog tijekom proteklog vremena naše jedinstvene i osobne povijesti (Foskett, 1978).
} 
Kao fundamentalne kategorije koje čine i opisuju predmetna područja nove opće sheme počinju se razmatrati stvari i aktivnosti u kojima stvari participiraju (CRG, 1961; Austin, 1974). Stvari su u tom fundamentalnom smislu na početku rada na općoj shemi shvaćene kao oblici fizičke energije, materijali, teorije ili propozicije, ali ih se više ne gleda u rakursu glavnih (najčešće disciplinarno određenih) klasa već u rakursu cjeline sveg znanja (CRG, 1961; Austin, 1974). Smatralo se da bi time shema postala hospitalnija spram novog znanja bez obzira na to što se time istovremeno gubi jedinstvo tradicionalnih disciplina (CRG, 1961). Za svrhu jasnije definicije stvari određuje se da toj kategoriji pripada bilo koji koncept koji se može razmatrati izvan konteksta te koji time poprima ili literarno ili mentalno jamstvo (ibid.). Time je osigurano da se klasifikacija, ali i drugi sustavi za organizaciju znanja, mogu baviti svime onime što je zabilježivo i mislivo. Ideja za takav pristup dolazi od J. E. L. Farradanea koji je 1961. godine u ključnom članku o relacijskom indeksiranju postavio da bi se klasifikaciju trebalo temeljiti na terminima, a ne na pretpostavljenim predmetima glavnih klasa (Farradane, 1961.; Foskett, 1962). Prema tome pristupu predmet dokumenta potrebno je rastaviti na termine koji ga sačinjavaju tzv. izolate (engl. isolate) koje se može stavljati u raznorodne odnose pomoću relacijskih simbola ili operatora (Farradane, 1961.; Foskett, 1962). Sekvencu relacijski analiziranog predmeta kojeg čine izolati u specificiranim odnosima Farradane je imenovao riječju analat (engl. analet), dok se sam proces otkrivanja vrste odnosa u kojima neki izolati mogu stajati naziva relacijska analiza (Farradane, 1961.; Foskett, 1962). Postupak relacijske analize u klasifikaciji temelji se na semantičkom faktoriranju tj. raščlanjivanju značenja kompleksnog termina na određeni broj općenitijih termina koji određuju njegova svojstva (CRG, 1961). ${ }^{15,16}$

Farradaneov pristup možemo smatrati esencijalističkim pristupom klasifikaciji. Naime, njime se postiže da je smještaj pojedine stvari određen isključivo na temelju poznatih, intrinzičnih karakteristika prema kojima je ona jedinstveno odrediva odbacujući pritom izvanjske i pripisane karakteristike (ibid.). Tako se dijamant može smatrati draguljem zbog njegovih estetskih karakteristika i ekonomske vrijednosti ili vrijednim materijalom u industrijskom smislu, no on je zapravo jedinstveno i intrinzično odrediv samo kao mineral (ibid.).

\footnotetext{
${ }^{15}$ U novom tisućljeću ove će postavke služiti kao osnova za ravoj klasifikacije po fenomenima i tretiranje disciplinarnih perspektiva kao faseta klasifikacijskih sustava.

${ }^{16}$ CRG (1961) daje primjer klase Zrak koja se u tradicionalnim sustavima nalazi u različitim područjima. Smatra se da je korisnije izdvojiti predmete iz područja i njih u adekvatnom redoslijedu uzeti kao okosnicu klasifikacije za razliku od ponavljanja klase Zrak u svakom od područja s kojim je povezana. Time je osigurano da će sve zabilježeno o fenomenu Zraka biti povezano i pretraživo pod klasom Zrak.
} 
Redanje stvari prema integrativnim razinama inicijalno je zamišljeno u sljedećem rasporedu:

1. „Temeljne čestice

2. Jezgre

3. Atomi

4. Molekule

5. Molekularne agregacije

6. Stanice

7. Organizmi

8. Ljudska bića

9. Ljudske zajednice

10. Ljudski intelektualni, imaginativni, i umjetnički produkti“ (ibid., str. 158).

CRG navodi (1964), kao rezultat jedne od svojih rasprava, da se u ovako postavljenom univerzumu znanja može govoriti o nekoliko klasa koje sadrže pojedine tipove stvari koje nalazimo u svijetu [o. a. redoslijed prilagođen]: kemijski entiteti, fizički entiteti, heterogeni ne-živući entiteti, biološki entiteti, čovjek, artefakti i mentefakti. Ipak, CRG nije ponudio njihov konačan redoslijed sukladan teoriji integrativnih razina (Spitteri, 1995). To će učiniti tek Claudio Gnoli u novom tisućljeću u okviru projekta Klasifikacija integrativnih razina (vidi poglavlje o Klasifikaciji fenomena). Svrha je spomenute rasprave CRG-a bila razotkriti principe ili razine organizacije u svijetu pa tako možemo govoriti o evolucionarnom kriteriju prema kojem među integrativnim razinama postoje entiteti različite kompleksnosti zbog karakteristika koje su poprimili tijekom svoje evolucije. Spitteri (1995) govori o tome kriteriju kao o razvojnoj progresiji entiteta temeljenoj na strukturi njihovih karakteristika tj. o evolucionarnom razvoju entiteta. Razine se unutar sebe sortiraju prema evolucionarnom kriteriju pri čemu se redanje utvrđuje prema razini kompleksnosti pojedinog fenomena čovjek je kompleksniji od medvjeda zbog načina na koji koristi ruke, glas, jezik, itd. (CRG, 1964).

Važno je razlikovanje razine artefakata $\mathrm{i}$ razine imenovane novokovanicom - mentefakti $^{17}$ (ibid.). Artefakti su produkti tj. fizičke stvari koje je stvorio čovjek, dok su mentefakti umne stvari koje čovjek osmislio korištenjem intelekta koja sadrži sve od ideje broja i jedinice do

\footnotetext{
${ }^{17}$ Foskett (1978) novokovanicu atribuira Barbari Kyle.
} 
sistema mišljenja, disciplina i umijeća (ibid.). Usto, definirane su i agregatne razine ${ }^{18} \mathrm{tj}$. stvari koje nastaju kada neki broj jedinica nižih razina čini sustavnu novu cjelinu (ibid.). Zanimljivo je, a istovremeno i neadresirano, da prema predstavljenom modelu, artefakti i mentefakti čine višu evolucionarnu razinu od samog čovjeka koji ih je stvorio.

Prednost je teorije integrativnih razina što razrješava problem složenih predmeta koji su sastavljen od izolata koji dolaze iz nekoliko različitih glavnih klasa što je bila velika mana tradicionalnih sustava koji ne mogu pružiti takvu fleksibilnost (CRG, 1961). Relacijskom analizom i raščlanjivanjem predmeta na izolate omogućeno je da se predmete klasificira prema integrativnoj razini najkompleksnijeg izolata (ibid.). Time je postignuta vrsta okupljanja povezanih predmeta kakva ne postoji u tradicionalnim sustavima (ibid.). Istovremeno, izbjegava se da se stvari umeću pod klase koje reprezentiraju samo neke aspekte pojedine stvari jer se u novom modelu za svaku stvar mogu točno precizirati aspekti (različitih razina kompleksnosti) s kojih je stvar razmatrana tj. aspekt neće biti pretpostavljen ili nametnut (ibid.). Drugim riječima, omogućava se da se neka stvar klasificira bez obzira ili s obzirom na kontekst iz kojeg dolazi (u doslovnom literarnom smislu vjernom predlošku ili u idejno misaonom smislu na temelju onoga što su korisne zamislive relacije neke stvari) (ibid.).

U klasifikaciji temeljenoj na teoriji integrativnih razina CRG nastoji izbjeći klasificiranje pomoću višestrukih unosa (ibid.). Preferira se jedna oznaka za jedan predmet kako bi uvijek bilo jedinstveno određeno gdje u redoslijedu treba stajati neko djelo. To se načelo mora odnositi i na dokumente koji se sveobuhvatno bave predmetima iz različitih aspekata tj. gledišta (ibid.).

Ova su promišljanja i postavke klasifikacije dovele CRG do rasprave o tome što uopće čini predmetno područje (ibid.). Postignut je konsenzus okupljenih stručnjaka da ne postoje trajne prirodne podjele u univerzumu znanja koje bi tvorile omeđena predmetna područja (ibid.). CRG polazi od pretpostavke da su predmetna područja kompleksi koji su nastali kao skup elementarnih stvari i aktivnosti na temelju koji se pojedino područje može opisati (ibid.). Stoga, smatra se da su predmetna područja arbitrarna grupiranja pojedinih kategorija na pojedinim razinama integracije te da to upućuje na zaključak da su discipline privremene i promjenjive kategorije neomeđenog opsega u stalnom stanju razvoja (ibid.).

${ }^{18}$ Razina agregacija uzima se i kao mjesto razdiobe tranzitivnih i intranzitivni entiteta tj. onih koji mogu djelovati na nešto drugo i onih koji ne mogu, pri čemu molekularne agregacije predstavljaju prvu razinu tranzitivnih entiteta, a one niže razine smatraju se intranzitivnim. 
U nastavku vlastitih rasprava o integrativnim razinama $\mathrm{CRG}$ je naišao na problem klasifikacije aktivnosti (CRG, 1964). Dok stvari, entiteti i konkretnosti (engl. concretes) lako upadaju u pojedine razine, ostaje nejasno na kojoj razini treba bilježiti pojedine aktivnosti (ibid.). Predloženo je pravilo da ih se uvodi na onu razinu gdje postoji najniža razina osobnosti koja može provesti spornu aktivnost u cijelosti (ibid.).

Period do kraja 1964. godine obilježio je i tzv. Cranfield projekt pod vodstvom Cyrila Cleverdona (Cleverdon, 1960) čiji rad je omogućio kvantitativni opis relevantnih čimbenika sustava za organizaciju znanja (CRG, 1964). Opisao je ponašanje različitih sustava kada ih se izloži komparabilnim informacijskim zahtjevima i doprinio razvoju definicija mjera za vrednovanje sustava poput preciznosti, odziva, specifičnosti, iscrpnosti, pertinentnosti i relevantnosti $^{19}$ (ibid.). Članovi CRG-a imali su podijeljena mišljenja o rezultatima Cleverdonove analize, no nedvojbeno je da je ona pokazala da određene klasifikacijske prakse nisu bile izrazito učinkovite. Tako je, primjerice, kvantitativnim pokazateljima utvrđeno da je fasetni sustav najučinkovitiji kada je omogućen višestruki smještaj istih termina te kada ga se koristi post-koordinatno (ibid.). Utvrđeno je i da će lančano indeksiranje uvijek tvoriti suviše iscrpne i neučinkovite sustave (ibid.). Cleverdonova istraživanja pokazala su učinkovitost relacijskih pristupa te utvrdila da referenciranje unutar popisa termina djeluje povoljno na lakoću korištenja i snalaženje unutar sustava za organizaciju znanja (ibid.).

Ta će saznanja kasnije apostrofirati korisnost fasetnih pristupa pa je CRG-ovo uvjerenje da sve klasifikacijske sheme trebaju biti temeljene na fasetnoj analizi dobilo dodatnu podršku. Dodatna opravdanja za temeljenje opće sheme na teoriji integrativnih razina, prema Foskettu (1970) mogu se, uz filozofiju crpiti iz područja psihologije i sociologije. CRG je na temelju psihologijskih istraživanja o razvoju djeteta Brunera, Piageta, Guilforda i drugih bio inspiriran idejom da se koncepti o svijetu formiraju promatranjem svijeta oko sebe te da bi te spoznaje trebale biti informativne i kod konstrukcije klasifikacijskih shema novog kova (Foskett, 1970; 1980). Istraživanjem svoje okoline dijete razvija konceptualnu shemu svijeta oko sebe i razvija sposobnost apstrahiranja, a time i predviđanja što djetetu omogućuje da se nosi sa okolnostima u kojima se dosad nije našlo, a na temelju prethodnih spoznaja o svijetu u kojem se nalazi (Foskett, 1970; 1980). U tome se već očituje pristup iskazan u teoriji integrativnih razina (Foskett, 1970). Dijete ustanovljuje da su poznati objekti nastali od nekih drugih

\footnotetext{
${ }^{19}$ Detalji Cleverdonove analize mogu se pronaći u njegovom radu iz 1962. godine pod naslovom Izvještaj o testiranju i analizi istraživanja komparativne učinkovitosti indeksnih sustava (izvorno: Report on the testing and analysis of an investigation into the comparative efficiency of indexing systems).
} 
prethodno postojećih entiteta (ibid.). Foskett (1970) navodi primjer stolice, koja je sačinjena od drvnog materijala, a koji dolazi od drveta, a drvo je izraslo iz sjemena itd. Osim u psihologiji takav način mišljenja u društvenim znanostima locira u radu Emila Durkheima, Friedricha Engelsa i drugih (Foskett, 1970; 1980). Kao iduću razinu nakon fasetne analize vidio je otkrivanje načina kako primjereno analizirati entitete i odnose među njima te je smatrao da će opća teorija sustava koju je razvio Ludwig von Bertalanffy 1930-ih godina tu biti od pomoći (Foskett, 1970; 1980) ${ }^{20}$.

Rad CRG-a na općoj klasifikacijskoj shemi dobio je 1962. godine i svoju prvu financijsku potporu. Sjeveroatlantski savez (NATO) Britanskom knjižničnom udruženju dodjeljuje grant za izradu opće klasifikacije (CRG, 1964; Austin, 1974). Već u početku odlučeno je da će se nova opća shema temeljiti na teoriji integrativnih razina, da shema neće biti organizirana prema tradicionalnim glavnim klasama i disciplinama, da enumeraciju ${ }^{21}$ treba izbjegavati pod svaku cijenu te da se koncepti mogu pojavljivati samo jednom u shemi, da moraju biti jedinstveno odredivi i povezivani relatorima (CRG, 1964; 1968). Posebno je naglašena važnost obradivosti i iskoristivosti sheme u strojno-računalnom smislu (CRG, 1968).

Konstrukcija opće sheme otkrila je i niz točki neslaganja među vodećim klasifikacijskim stručnjacima. Među tim neslaganjima zanimljivo je ono koje se opisuje u desetom CRG Biltenu iz 1973. godine. Naime, temeljenje klasifikacije na teoriji integrativnih razina dovelo bi do toga da se klasifikacije počnu baviti konceptima koji čine univerzum, za razliku od razumijevanja da se klasifikacije trebaju ticati znanja u onome obliku u kojem ga se može pronaći u literaturi tj. da se klasifikacije moraju odnositi na ono što je rečeno ili zapisano o stvarima (CRG, 1973). Kritičari unutar CRG-a poput Fairthornea iznose stajalište da je klasifikacija temeljena na konceptima promašaj jer nije moguće definirati klase koje bi svima odgovarale (ibid.). Langridge napominje da je potrebno razlikovati klasifikaciju fenomena s obzirom na to kako ih uočava čovjek i klasifikaciju znanja o fenomenima (ibid.). Prema njemu CRG se do sada usmjeravao isključivo na prirodne znanosti i time zanemarivao druge

\footnotetext{
${ }^{20}$ Zanimljivo je također da Foskett 1970-ih godina zagovara odmak od redukcionizma na temelju rada Arthura Koestlera kao ideje da se sve ljudske aktivnosti mogu svesti na elementarne reakcije kakve uočavamo u nižih životinja te da naše reakcije mogu biti svedene na osnovne fizio-kemijske zakone. $\mathrm{U}$ tome se određenju i odbacivanju redukcionizma podudara s viđenjem iste problematike kakvo oblikuju autori u području integrativne bioetike.

${ }^{21}$ Foskett daje zanimljiv primjer u svome članku iz 1978. godine. Prilikom analize posotojećih klasifikacija i debatiranju o primjerenosti teorije integrativnih razina kao osnove nove opće klasifikacije sudionici su naišli na problem enumeracije u okviru koncepta "kurikulum" gdje bi se, primjenjujući logiku enumeracije dosljedno, trebalo unutar zamišljene klasifikacije ponoviti i enumerirati cijeli univerzum znanja kao mogući sadržaj nastave tj. obrazovanja. Paradoksi ovog tipa jedan su od razloga zašto je CRG odlučio izbjegavati enumeraciju pod svaku cijenu.
} 
forme znanja koje se pojavljuju u fundamentalnim disciplinama ${ }^{22}$ poput povijesti, filozofije, religije i umjetnosti (ibid.). Pojam fundamentalne discipline koristi kako bi objasnio da mimo prirodnih znanosti postoje forme znanja koje podrazumijevaju različite načine gledanja na svijet (temeljene na različitim pretpostavkama gdje se različite vrste zaključaka i dokaza smatra validnima) te među kojima ne postoji jedinstvo znanja (ibid.). Upravo zbog toga što one u ukupnoj slici univerzuma znanja odražavaju njegovu stvarniju kompleksnost, fundamentalne bi discipline trebale biti osnova strukture opće klasifikacijske sheme (ibid.). Langridge poentira da je na znanost orijentirani pristup doveo do toga da su fundamentalne discipline raspršene kroz cijelu opću shemu (npr. u UDK) gdje su primjerice filozofija i povijest znanosti smatrane aspektima znanosti, a ne grane povijesti odnosno filozofije (ibid.). S druge strane rasprave, Farradane nastoji obraniti teoriju integrativnih razina. Slaže se da ne možemo klasificirati stvarne objekte već samo ono što o njima znamo tj. ono što je o njima zabilježeno, no smatra da se klasifikacija mora temeljiti na prirodi našeg mišljenja, a ako je naše mišljenje znanstveno tada bi i klasifikacija trebala biti znanstveno utemeljena (ibid.). Radi se o tome da u filozofiji, umjetnosti i znanosti postoji različit način razmišljanja znanost gleda uzroke i posljedice, dok se filozofija više temelji na asocijativnom mišljenju, a te je asocijacije teško pouzdano analizirati jer nema mogućnosti direktne opservacije apstraktnih koncepata kojima filozofija ili umjetnost barataju (ibid.). Ipak, Farradane smatra da će opća klasifikacijska shema temeljena na konceptima ( $c f$. Farradane, 1967) koju postepeno gradi sinteza jednostavnih koncepata s vremenom dovesti do svih klasnih termina $\mathrm{i}$ disciplina kao i mogućnosti da se shema nosi sa svim gledištima (CRG, 1973). Ponavlja ključne konstrukcijske principe nove opće sheme: jedan termin, jedno mjesto; potpuna hospitalnost za unošenje novih koncepata; svi složeni predmeti trebaju biti reprezentirani sintezom; jasni odnosi moraju biti baza sinteze; vrste odnosa moraju biti jasno razgraničene (ibid.). Farradane zaključuje da se discipline mogu izvesti iz različitih načina na koji promatraju i prikazuju fenomene te da bi neke od tih mogle odgovarati fundamentalnim disciplinama kako ih shvaća Langridge, no da one ne mogu biti prihvaćene a priori (ibid.). Rasprava o primjenjivosti teorije integrativnih razina nastavljena je i u idućem periodu (CRG, 1978; 1985) no fokus se usmjerava na istraživanje njene primjenjivosti na humanističko i društveno područje ponukana revizijom Blissove klasifikacije kada će u rasprave postepeno biti uveden pojam društvenih fenomena i potreba njihove kvalifikacije pojedinim gledištima. Richmond (u Foskett, 1978, cf. Gnoli, 2004a) suprotno kritici da se teorija integrativnih

${ }^{22}$ O. a. pojam fundamentalne discipline nije direktno povezan $\mathrm{s}$ pojmom fundamentalnih kategorija $\mathrm{u}$ Ranganathanovom smislu tj. pojmom fasete. 
razina usmjerava isključivo na fenomene prirodnih znanosti smatra da je teorija primjenjiva i na mentalne tj. ne-fizičke vrste fenomena kao i njihove agregacije. Foskett (1980) objašnjava da prethodno spomenuta opća teorija sustava, čiji je teorija integrativnih razina izdanak, adekvatno rješava problem primjenjivosti teorije ${ }^{23}$ na humanističko i društveno područje. Naime, Foskett smatra da se opća teorija sustava vrlo dobro poklapa sa svom klasifikacijskom teorijom koju je uspostavio Ranganathan za univerzum znanja u cjelini. Prema općoj teoriji sustava „sustav je bilo koji entitet čije su karakteristike određene kao priroda njegovih dijelova i odnos među njima“ (ibid., str. 4). To ujedno i znači da su i aktivnosti nekog sustava nužan dio dijelova koji ga čine tj. i same su sastavni dio tog sustava (ibid.). Sustavi međusobno mogu stajati u hijerarhijskim relacijama tj. biti podređeni ili nadređeni nekog drugom sustavu (ibid.). Po pitanju predmeta humanističkih i društvenih znanosti poziva se na primjer Ervina Laszla koji ilustrira da je i čovjek vrsta kognitivnog sustava sam po sebi, a koji postoji s obzirom na unutarnje relacije između dijelova svoga tijela (podložne progresivnoj organizaciji na temelju osobnih iskustava $\mathrm{i}$ osobne povijesti) te $\mathrm{s}$ obzirom na izvanjske relacije sa svijetom i okolinom u kojoj živi (ibid.).

Rezultat NATO granta i pothvata stvaranja opće sheme bio je PRECIS (engl. Preserved Content Index System) sustav za indeksiranje (Miksa, 1994; CRG, 1973; Austin, 1974). Sustav nikada nije zaživio u potpunosti, bio je temeljen na općoj teoriji sustava (Miksa, 1994), a funkcionirao je kao strojno čitljiv hibrid tezaurusa i klasifikacije uspostavljen tzv. pristupom odozdo od definicija termina prema klasama (CRG, 1973). Temeljio se na dva već spomenuta postulata:

1. svi koncepti moraju biti uvedeni po jednom zauvijek principu u opće kategorije koje će ostati stabilne i validne u svim sintaktičkim situacijama, te da se

2. složeni termini moraju moći rascjepkati u zasebne konceptualne jedinice (ibid.).

Sustav je izrastao iz studije prirodnoga jezika i bio je poseban po tome što nije funkcionirao kao set prethodno propisanih termina ili fraza već se temeljio na nizu konzistentno primjenjivanih procedura (Austin, 1974). Činio ga je otvoreni rječnik koji je mogao uvrštavati termine čim bi oni bili uočeni u literaturi, pri čemu bi ih se potom sintaktički i semantički odredilo u odnosu na postojeće termine (ibid.). Sintaksa složenog predmeta uređuje se pomoću operatora uloge (engl. role operators) koji definiraju odnose među terminima, dok su semantički odnosi uređeni setom pravila kojima se indekser mora povoditi pri indeksiranju

\footnotetext{
${ }^{23}$ i. e. teorije integrativnih razina
} 
(npr. da se u sekvenci nikada ne iskazuje cijeli hijerarhijski smještaj centralnog termina složenog predmeta već se na termine smještene niže i više u hijerarhiji uvijek upućuje Vidi $i$ vrstom reference) (ibid.). Za svaki se tako definirani predmet automatski dodjeljuje adresa kako bi se mogle definirati tezauralne relacije između svake dvije adrese i postigla referentnost (ibid.). ${ }^{24}$

${ }^{24} \mathrm{Za}$ detaljno objašnjenje sintakse predmeta i uređenje semantički odnosa među njima u PRECIS sustavu vidi Austin, 1974. 


\section{CRG-ove revizije postojećih klasifikacija i njihove pouke}

Nakon 1955. godine i izdavanja CRG-ova memoranduma o fasetizaciji kao osnovi svih klasifikacijskih sustava dio članova uključio se u rad na reviziji postojećih klasifikacija. Za razvoj opće sheme i ideje njena temeljenja na teoriji integrativnih razina relevantan je slučaj revizije Blissove bibliografske klasifikacije (CRG, 1973). Jedan je od osnovnih principa Blissove klasifikacija gradacija po specijalnosti što u određenoj mjeri odražava logiku teorije integrativnih razina (ibid.). U reviziji je primijećeno da se klasifikacije pretjerano oslanjaju na literarno jamstvo što znači da teško inkorporiraju nove teme ili nova interdisciplinarna grupiranja koje traže svoje mjesto ${ }^{25}$ te je CRG općenito zaključio da okvir za opću klasifikaciju ne smije biti rigidno definiran na temelju onoga što postoji sada, već da mora biti dovoljno fleksibilan da udomaći nove koncepte (ibid.). Ponavlja se i primjer fenomena poput vode kojim se autori često bave iz različitih perspektiva koje su raspršene po cijeloj klasifikacijskoj shemi, a to znači da dokumenti o istom fenomenu neće biti okupljeni na istome mjestu (ibid.).

Proces revizija postojećih klasifikacije ozbiljnije inaugurira i raspravu o poziciji gledišta u strukturi nove opće sheme (više u CRG, 1978). Izraženo je mišljenje da gledište autora treba klasificirati ako je riječ o odstupanju od očekivanog gledišta koje bi moglo utjecati na korisnikovu odluku da odbaci informacijski izvor (ibid.).

Tijekom revizije Općeg sustava redanja (engl. Broad System of Ordering; i.e. BSO) pojavljuje se primjer jedne specifične klase za koju nije lako jedinstveno odrediti je li riječ o disciplini ili fenomenu, a riječ je o klasi Ljudske potrebe (ibid.). Coates objašnjava da je klasa stvorena kako bi udomaćila pojedine entitete i fenomene reprezentirane na transdisciplinarni način kako bi BSO bio spreman ponuditi rješenje za sve izvore na koje se tada primjenjivao (ibid.). Naime, ostatak sheme značajno se temeljio na disciplinarnom pristupu, no uočeno je da nije moguće klasificirati sve izvore postojećim disciplinarno utemeljenim klasama (ibid.). Pristup dodavanja transdisciplinarne reprezentacije kritiziran jer je prema Langridgeu uveo dodatan princip strukturiranja sheme koji ne prožima cijelu shemu, dok je Mills smatrao da je klasa preheterogena da bi njena podjela klasa uopće mogla stajati okupljena na jednome mjestu (ibid.). Coates je stvaranje klase branio činjenicom da postoji stvarna potreba da se

\footnotetext{
${ }^{25}$ Dan je primjer klasificiranja tehnologija koje se često uvodi na temelju njihove primarne svrhe i načina korištenja, no kada se ista tehnologija koristi za nešto drugo u novim okolnostima tada klasifikacija podbacuje jer taj način korištenja nema jasno definirano svoje mjesto (CRG, 1973).
} 
djela tako klasificira te je objasnio da bi za ovakva područja, poput područja Ljudske potrebe, trebali vrijediti sljedeći principi inkluzije:

1. postojanje organizacija koje se bave predmetom;

2. postojanje zbirki podataka i servisa za kreiranje znanstvenih sažetaka u području;

3. postojanje časopisa koji se specifično bave predmetom; te

4. postojanje sveučilišnih odjela koji se specifično bave predmetom (ibid.).

Smatralo se da će u budućnosti biti sve više takvih klasa i klasifikacijskih potreba (ibid.). Područje bioetike, i specifično integrativne bioetike kojim se bavi ova doktorska disertacija, zasigurno je primjer takve potrebe za transdisciplinarnom reprezentacijom predmeta pojedinog područja. 


\section{Pomak od klasifikacije prema organizaciji znanja}

Sedamdesete i osamdesete godine proteklog stoljeća obilježene su s jedne strane retrospektivama na dosege intelektualnog pristupa izgradnji klasifikacija i istraživanjima njihove kompatibilnosti s drugim sustavima za organizaciju znanja (e. g. Sweeney, 1983; Long, 1984; Vickery, 1986; Tedd, 1987, Coates, 1988; Foskett, 1988) dok s druge strane dolazi i do novih perspektiva u području. Naime, znanstvenici u području klasifikacije bivaju sve snažnije zainteresirani za primjenu računala u izgradnji sustava za organizaciju znanja (Dahlberg, 1989), a istraživački trend poznat pod nazivom pretraživanje informacija (engl. information retrieval) kao izdanak tog interesa sazrijeva u stabilno znanstveno područje (Lesk, 1998).

U tim uvjetima Ingetraut Dahlberg 1989. godine osniva Međunarodno društvo za organizaciju znanja koje na temelju njenih istraživanja nastoji slijediti viziju jednog univerzalnog klasifikacijskog sustava za potrebe pretraživanja, a koji bi bio zasnovan na rigoroznoj analizi koncepata (Miksa, 1994; Dahlberg, 1989). U Uvodniku drugog broja časopisa Međunarodna klasifikacija ${ }^{26}$ iz 1989. godine Dahlberg objašnjava da je jedan od temeljnih razloga za osnivanje društva bila potreba da postoji međunarodno društvo koje se ne usmjerava toliko na matematičko-statističke metode i tzv. numerički pristup u području već gaji onaj intelektualni i konceptualni pristup izgradnji sustava za organizaciju znanja. Ingetraut Dahlberg najčešće se smatra utemeljiteljicom organizacije znanja kao znanstvenog područja, no sam naziv preuzima od Henryja Blissa koji uspostavlja obrise područja ${ }^{27}$ (Arboit, 2018). Spomenuti konceptualni pristup zapravo je razvoj Ranganathanovog kognitivističkog pristupa koji Dahlberg preuzima i formulira u tzv. teoriju koncepta koja bi trebala služiti kao nova teorijska osnova za područje organizacije znanja (Arboit, 2018; Hjørland, 2021). Konceptualni pristup odnosi se na pogled da se informacijske znanosti i klasifikacija moraju odnositi na konceptualne strukture i proces oblikovanja koncepata (engl. concept formation) (Arboit, 2018). Prema Dahlberg, bibliografske klasifikacije samo su podvrsta konceptualnih sustava. Zbog toga smatra da se takve klasifikacije moraju baviti sistematizacijom reprezentacija koncepata. Koncepti su prema Dahlberg: „osnovne jedinice mišljenja koje sintetiziraju stvarne i nužne karakteristike za određenje nekog objekta i koje su komunicirane pomoću lingvističkih znakova.“ (ibid., str. 130). Arboit (2018) smatra da se u toj definiciji

\footnotetext{
${ }^{26}$ Kasnije mijenja naziv u Organizacija znanja.

${ }^{27}$ Bliss 1929. koristi engleski termin "organization of knowledge" kojeg Dahlberg koristi u inverziji "knowledge organization".
} 
razotkriva njena ranganathanijanska tj. kognitivističko-idealistička vizija znanja jer prema ovoj definiciji ideje prethode riječima, a oblikuju se u umu pojedinaca. Prema Dahlberg, kroz govoreni ili pisani jezik može se prenijeti samo reprezentacija nekog znanja (Dahlberg, 2006; Arboit, 2018) te to služi kao opravdanje interesa za istraživanje kognitivnih modela ljudskog uma.

Kognitivistički pristupi često se poistovjećuju s pristupima temeljenim na korisnicima jer se odnose na kognitivnu analizu potreba i sposobnosti korisnika sustava za organizaciju znanja (Ingwersen, Järvelin, 2005; Hjørland, 2021), a sam početak njihova razvoja locira se u sedamdesetim godinama kada kognitivizam ostvaruje zamah u znanosti općenito. Svoju osnovu ovi pristupi lociraju u kognitivnoj psihologiji, a zanima ih kako koncepti nastaju u ljudskom umu te kako taj proces informira izgradnju sustava za organizaciju znanja i proces pretraživanja informacija. Kognitivistički pristup gleda na um univerzalistički, tražeći univerzalne obrasce i mehanizme prepoznatljive u umu svih ljudi. Prema De Mey (kod Hjørland, 2021) riječ je „o bilo kojem procesuiranju informacija, perceptualnom ili simboličkom, koje se zbiva u okviru nekog sustava kategorija i koncepata koji, za biće koje procesira te informacije, predstavlja model njegova svijeta“ (može biti riječ o čovjeku, računalu itd.). Prema Dahlberg (kod ibid.), sustavi za pretraživanje informacija trebali bi odražavati taj kognitivni svijet korisnika sustava.

Kritika kognitivizma u organizaciji znanja viševrsna je. Primjerice, Hjørland (2021) smatra problematičnim da informacije potrebne za konstrukciju sustava za organizaciju znanja dolaze od korisnika, a ne iz domene znanja u kojoj se znanje organizira, dok se uloga povijesti, kulture i društva u spoznavanju svijeta zanemaruje. Frohmann (kod ibid.) optužuje kognitivizam za tzv. mentalizam tj. neopravdano pretjeranu usmjerenost na kognitivne procese ljudskog uma koji čini praksu indeksiranja otuđenom, ahistorijskom, besklasnom, o rodu neovisnom i univerzalističkom praksom. Na sličnom pragu, Andersen (kod ibid.) smatra da kognitivizam nudi isključivo arbitrarne, a time neiskoristive modele ljudskog uma, pamćenja i kognicije koji nisu uspjeli pridonijeti objašnjenju procesa indeksiranja ili izgradnje sustava za organizaciju znanja. Hjørland (2021) psihologijski utemeljenim pristupima kontrastira one epistemološke i smatra da bi područje trebalo napustiti interes za opće modele uma i umjesto toga istraživati načine mišljenja u različitim znanstvenim disciplinama i zajednicama ljudi tj. razotkrivati paradigme koje ih strukturiraju. Potrebna je dakle, 
preorijentacija na specifične domene znanja i istraživanje informacijskih potreba i zahtjeva unutar njih.

Važno je na ovom mjestu istaknuti da interes za područje pretraživanja informacija (engl. information retrieval) ipak refokusira područje klasifikacije što dovodi do zapostavljanja nekih od započetih projekata (Gnoli, 2006) poput opisanog sustava PRECIS ili započetih revizija tradicionalnih sustava. U svom osvrtu na 6. međunarodnoj studijskoj konferenciji o klasifikacijskim istraživanjima održanoj 1997. godine u Londonu prominentni stručnjak Brian Vickery (1997) osvrnuo se na promjene u klasifikacijskom mišljenju od 1947. godine tj. konferencije u Dorkingu ${ }^{28}$. Napredak područja vidio je u uskoj interdisciplinarnoj suradnji znanstvenika koji razvijaju ontologije u području umjetne inteligencije i informacijskih znanstvenika. Upravo zbog te nove kompleksnosti zadataka u području smatrao je da znanstvenici trebaju obgrliti termin organizacije znanja kao novu normu i napustiti usko bavljenje klasifikacijom i malim opsegom tezauralnih odnosa. Vickery (1997) ističe kako sama reprezentacija ambigviteta univerzuma znanja nije konačna svrha organizacije znanja već uvijek treba imati na umu njenu aplikaciju i korist u traženju informacija i razrješenju informacijskih potreba.

Komentar Briana Vickeryja ilustrira zadivljenost stručnjaka u području organizacije znanja mogućnostima koje otvara primjena računala. Nakon 1950-ih potencijal novih pristupa, sistemski orijentiranih, usmjerenih na pretraživanje informacija zasjenjuje epistemološki i sociološki orijentirane dokumentalističke pristupe informacijskim znanostima i organizaciji znanja. Sistemska paradigma u prvi plan stavlja istraživanje kvantitativnih mjera učinkovitosti informacijskih sustava (poput odziva i preciznosti), nastoji statistički modelirati karakteristike dokumenata i automatizirati organizaciju znanja primjenom umjetne inteligencije i tehnika obrade prirodnog jezika (Hjørland, 2003). Razdoblje do 1990-ih godina obilježava niz seminalnih inovacija u području pretraživanja informacija i računarstva koji temeljito mijenjaju izgled područja informacijskih znanosti (npr. Cranfield eksperimenti Cyrila Cleverdona, izum citacijskog indeksiranja Eugene Garfielda, razvoj sustava MEDLARS, ASK model Nicholasa Belkina, razvoj OPAC-a, hiperteksta i World Wide Weba). Hjørland (2003) navodi da je računalna tehnologija omogućila različite vrste predmetnih pristupnica

\footnotetext{
${ }^{28}$ U reminiscenciji otkriva kako se već tada govorilo o problemu raznorodnosti perspektiva u klasifikaciji koje dupliraju istoznačne koncepte u različitim dijelovima klasifikacije, ponekad po istim, a ponekad pod različitim terminima istoga opsega značenja. Kao rješenje s kojim se 1997. godine prema njemu (Vickery, 1997) slaže većina struke navodi tzv. polihijerarhije perspektiva i ontologije u kojima je znanje strukturirano u niz mikrolatica koje će moći podnijeti reprezentaciju različitih perspektiva.
} 
(engl. subject access points i.e. SAP) te time knjižničari i informacijski stručnjaci gube monopol nad osiguranjem predmetnog pristupa informacijama. Kvantitativna orijentiranost novih pristupa počela se manje baviti značenjem i metafizičkim dimenzijama predmeta te se u empiricističkoj i tzv. atomističkoj maniri usmjerava na specifične termine zaista prisutne $u$ tekstovima dokumenata (ibid.). Sužavanje istraživačkog horizonta prema Hjørlandu (2003) vidi se i u pokušaju formalizacije i automatizacije s ciljem eliminacije ljudske interpretacije i predmetne analize u korist mehanizacije tih postupaka.

Prema Hjørlandu (2021) kognitivistički pristupi organizaciji znanja, psiholingvistička rješenja i pristupi pretraživanju informacija i organizaciji znanja utemeljeni na umjetnoj inteligenciji išli su ruku pod ruku uzimajući kognitivnu psihologiju kao teorijsku bazu svojih istraživanja i praktičnih rješenja pa je taj spoj interesa predstavljao zasebnu epohu, ali i dominantan pristup u području koji se održao sve do danas bez obzira na kritike. Dolazi do zamućenja granica između računalne znanosti (engl. computer science) i knjižničnih i informacijskih znanosti jer sebe, u kontekstu utjecaja novih tehnologija, neki informacijski znanstvenici više ne smatraju dijelom knjižnične znanosti (Hjørland, 2003). Hjørland (2003) nagoviješta da je ovdje riječ o paradigmatskom sukobu jer su misije jednoga i drugoga područja disparatne zbog toga što je svrha knjižničnih i informacijskih znanosti optimizacija iskoristivosti zabilježenog znanja i pružanje intelektualnog i fizičkog pristupa informacijama, dok se računalna znanost bavi procesiranjem informacija, rješenjem problema pomoću algoritama i dizajnom i programiranjem računala. Cilj knjižničarstva, prema Hjørlandu (2003) nije izgradnja ekspertnih sustava izrađenih na temelju poopćenih kognitivnih modela, već prikazati univerzum znanja sa svim njegovim kompleksnostima, kontradiktornostima i nedostacima. Pred knjižničnu i informacijsku znanost time se postavlja zadaća refleksivnosti nad čovjekovim epistemičkim praksama.

Taj drugačiji, na interpretaciji utemeljen, pristup dokumentalistici svoje začetke pronalazi već u citacijskom indeksiranju Eugena Garfielda, kada u fokus dolaze mreže dokumenata i njihovi međuodnosi (ibid.). Citacijska analiza pokazuje da predmetna povezanost dokumenata ovisi o faktorima izvan analiziranih dokumenata samih s obzirom na to da dokument koji citira i onaj koji biva citiran ne moraju sadržavati niti jedan isti termin. Popis literature pojedinog stručnog ili znanstvenog članka upućuje na analizu područja koje je proveo autor prilikom pretraživanja postojeće literature $u$ području kojim se bavi (ibid.). Popisi literature razotkrivaju interpretacijski i argumentacijski put autora na temelju kojeg postulira problem 
kojim se bavi u svojim publikacijama i za nj nudi rješenja. Analizom citata reinterpretiramo taj autorev put koji je prema Hjørlandu (2003) opterećen i nizom društvenih i afektivnih tj. izvanznanstvenih čimbenika (citira se zbog reputacije, namjere impresioniranja itd.). Razvojem područja pretraživanja informacija postalo je moguće cjeloviti tekst dokumenta $i$ svaku pojedinu riječ gledati kao na moguću pristupnicu dokumentu, no pristup dokumentu putem sadržaja nije doživio takvu vrstu tehnološke revolucije. Naime, ostavimo li po strani naivne interpretacije sadržaja dokumenta prema kojem je definicija njegova opsega iscrpljena eksplicitnim iskazima sadržaja u samom tekstu dokumenta, Hjørlandovo (2003) mišljenje ukazuje na to da je zadaća informacijskog stručnjaka razotkriti i sustavno organizirati i sve one informativne i epistemološke potencijalnosti dokumenta koje postaju razvidne bilo kontekstualizacijom dokumenta $\mathrm{u}$ datoj povijesnoj i društvenoj situaciji njegova nastanka ili pak njegovom rekontekstualizacijom u aktualnoj ili pretpostavljenoj budućoj povijesnoj i društvenoj situaciji. Time Hjørland (2003) nadograđuje i zadaće organizacije znanja jer traži da uz intelektualnu ili kognitivnu organizaciju znanja započnemo i razmatranje socijalne organizacije znanja koja se odražava u „organizaciji profesija, zanata i disciplina“ Hjørland (ibid., str. 93). Područje organizacije znanja time se neosviješteno bavilo već od 1846. godine tj. od Melvila Deweya i njegove decimalne klasifikacije, no nije do novijeg vremena razvilo nikakav specifičan i usustavljen set metodoloških postupaka kojima bi istražila društvenoepistemološke dimenzije disciplinarnog zabilježenog znanja kojeg, naime aktivno organizira već desetljećima. Nagovještaj novog pristupa vidljiv je već i u radu Barbare Kyle iz 1958. godine o klasifikaciji u području društvenih znanosti koja naglašava da se ideja klasifikacije nalazi pred teleološkom reorijentacijom tj. da mora služiti kao odraz načina organizacije znanja pojedinog povijesnog perioda te da je uvjetovana socijalnom epistemologijom toga doba. Iz toga mišljenja proizlazi da ne postoji fundamentalni poredak prirode kao i odbacivanje uvjerenja da postoji jedna, univerzalna, logički podijeljena klasifikacija znanja koju čovjek mora tek razotkriti (Kyle, 1958). Kyle (1958) smatra da bismo izgradnjom univerzalne sheme ujedno postigli mogućnost prognosticiranja načina organizacije svog budućeg ljudskog znanja kao i moć predviđanja što će čovjek sve naučiti prije nego je to zaista naučio te ističe da bi to dovelo do stabilizacije intelektualnih procesa društva sve do točke stagnacije.

Područje organizacije znanja doživjelo je mnoge važne konceptualne doprinose kao što su spomenuti fasetno-analitički pristupi klasifikaciji, tradicija pretraživanja informacija (engl. information retrieval tradition), korisnički pristupi i bibliometrija (Hjørland, 2008), no tek se 
s pojavom i populariziranjem bibliometrijskih istraživanja pojavljuju prve naznake metodološki adekvatnijeg pristupa opisu disciplina (Hjørland, 2003). Sociološku organizaciju znanja Hjørland i Albrechtsen u svome članku iz 1995. godine programiraju u novu paradigmu za informacijske znanosti pod nazivom analiza domene.

Hjørland zauzima pragmatistički i historicistički pristup kao odgovor na empiricizam i racionalizam ranijih pozitivističkih, idealistički i kognitivističkih pristupa (Arboit, 2018). Za njega su koncepti jedinice mišljenja i znanja čija su značenja kolektivno dogovorena te čije određenje ovisi o specifikaciji semantičkih odnosa koji iz njih proizlaze (ibid.). Koncepte je potrebno razumjeti u njihovom društvenom i povijesnom kontekstu (ibid.). Smatra da su kognitivistički pristupi zastranili i odveli polje u smjeru koji je zanemario društvene zadaće područja (ibid.). Zagovara pragmatički pristup organizaciji znanja i želi njenu funkcionalističku orijentaciju tj. orijentaciju na konkretne praktične svrhe definirati na temelju kolektivnog konsenzusa o funkcionalnome $\mathrm{u}$ danom vremenskom i društvenom kontekstu (ibid.). Hjørland (2003) ističe i alternativne koncepcije koncepata te prezentira empiricističku (koju zbog isključive orijentacije na iskustvo odbacuje kao nepotpunu), racionalističku (koju odbacuje zbog prenaglašene uloge često arbitrarnih modela uma i univerzalističkog tretmana koncepata kao nečega što je neovisno od domene, interesa ili svjetonazora), kriticističku tj. empirijsko-racionalističku (s kojom se zasebno značajno ne suočava te koju izostavlja iz prikaza metoda klasifikacija), historicističku (koja mu je bliska zbog naglaska na povijesne procese $\mathrm{i}$ ulogu interesa, tradicija i društvenih zajednica $u$ oblikovanju koncepata) te pragmatističku i kritičko-realističku (koju podržava kao najnapredniji stadij konceptualizacije koncepata te prema kojoj se znanje i koncepti oblikuju ljudskom praktičnom aktivnošću u odnosu spram objekata te aktivnosti). Koncepti se usustavljuju u teorijama, a teorije su za njega, kao koherentni sustavi mišljenja, i same sustavi za organizaciju znanja (Hjørland, 2015) koji su instrumentalni za razumijevanje koncepata i njihove tvorbe. Prema tome, zbog brojnosti mogućih teorijskih pristupa, Hjørland (2003) smatra da su semantički odnosi između koncepata relativni s obzirom na teoriju i perspektivu razmatranja.

U novoj društvenoj paradigmi informacijskih znanosti kao društvenih znanosti temeljenoj na sociopsihološkim, sociolingvističkim i socioepistemološkim perspektivama prema utjecajnoj definiciji Birgera Hjørlanda (2008, str. 86) organizacija znanja, u užem smislu, „bavi se prirodom $i$ kvalitativnim obilježjima procesa organiziranja znanja, kao i sustava za 
organizaciju znanja, koji se koriste za organizaciju dokumenata te organizaciju reprezentacija dokumenata, djela i koncepata“. U širem smislu pak, organizacija znanja bavi se ,društvenom podjelom intelektualnog rada, tj. organizacijom sveučilišta $i$ drugih istraživačkih $i$ visokoškolskih institucija, strukturom disciplina i profesija, društvenom organizacijom medija, produkcijom $i$ diseminacijom znanja $i d r . “$ (ibid., str. 86). Uže, specijalizirano i na praktičku aktivnost usmjereno shvaćanje organizacije znanja neodvojivo je, dakle, od šireg teorijskog razumijevanja. Intelektualna ili kognitivna organizacija znanja neodvojiva je od društvene organizacije znanja. 


\section{Post-modernistički zaokret i analiza domene}

$\mathrm{U}$ tradicionalnom pogledu zadatak je organizacije znanja reprezentirati poredak prirode iz očišta znanstvene spoznaje, odnosno načina na koji discipline, kao jedinice društvene organizacije znanosti, razotkrivaju i opisuju strukture stvarnosti (Hjørland, 2008). Pojavom analize domene dolazi do preokreta u naravi rasprava u području organizacije znanja, ali i knjižničnim i informacijskim znanostima općenito. Analiza domene predstavlja odustajanje od univerzalističkih ${ }^{29}$ projekata dvadesetog stoljeća, priznanje uporabne moći računalnolingvističkih rješenja u osiguranju pristupa informacijskim izvorima (s čijim se izvorišnim disciplinama knjižnične i informacijske znanosti interdisciplinarno sljubljuju), ali i refokusiranje područja organizacije znanja na društvenu organizaciju znanja i produktivnu platformu domensko-specifičnih istraživanja diskurzivnih zajednica s ciljem organizacije znanja u pojedinim domenama i razumijevanja procesa produkcije, prijenosa i korištenja znanja. Domene se tretiraju kao zajednice mišljenja ili diskursa koje sudjeluju u društvenoj podjeli kognitivnog rada (Hjørland i Albrechtsen, 1995), a analizom domene otkriva se, bilježi i prati ontologija neke diskurzivne zajednice kao osnovica za izgradnju sustava za organizaciju znanja (Smiraglia, 2015). Domene su ,jedinice analize za konstrukciju sustava za organizaciju znanja. To jest, domena je grupa s ontološkom bazom koja razotkriva njenu pozadinsku teleologiju, set zajedničkih hipoteza, epistemološki konsenzus o metodološkim postupcima i društvenom značenju. Ukoliko, nakon sustavne analize, nije uspostavljen konsenzus o ovim točkama, tada se ne može definirati niti intenzija niti ekstenzija i grupa ne predstavlja domenu. [...] Domena je grupa koja [za svrhu ostvarenja zajedničkog cilja kojim opravdava svoje postojanje] treba ili stvara vlastiti sustav za organizaciju znanja“ (ibid., str. 5). Iako Smiraglia i drugi autori pretpostavljaju važnost sustava, valja istaknuti da su sustavi za organizaciju znanja pojedinim domenama potrebni kako bi se uspostavila, prikazala i mogla razumjeti društvena organizacija kognitivnog rada domene, osigurao pristup postojećem zabilježenom znanju u domeni, facilitirala inicijacija novih članova grupe i konsenzualno uspostavio kategorijalni i konceptualni aparat koji se koristi u domeni znanja, a koji pak, u povratnoj sprezi služi za komunikaciju rezultata domenskih aktivnosti i njihovo dokumentalno bilježenje. Prema Poliju (kod Smiraglie, 2015) analiza domene bavi se kategorijalno zatvorenim domenama znanja koje je prema Tennisu (2003) moguće opisati dvama pravcima prema kojima analiza domene funkcionira kao zaokruženi metodološki obrazac - intenzijom i ekstenzijom analize tj. njenom širinom i dubinom. Kao jedna od teorija

\footnotetext{
${ }^{29}$ Npr. Odustaje se o daljnjeg razvoja sustava PRECIS i revizije Blissove klasifikacije.
} 
definicije ekstenziteta $\mathrm{i}$ intenziteta neke domene uzima se i teorija integrativnih razina (Smiraglia, 2015), no Hjørland (2018) u recentnoj kritici ontološkog pristupa Claudia Gnolija izražava skepsu u primjenjivost te teorije za analizu domene.

Prema autorima Jensu-Eriku Maiu (1999) i Richardu P. Smiragli (2015) reorijentacija područja organizacije znanja na analizu domene značila je i zaokret prema postmodernom razumijevanju znanja. Smiraglia (2015) objašnjava da se fokus područja mijenja tj. da se cilj otkrivanja ontologija kao osnove organizacije znanja zamjenjuje postmodernim, egzistencijalističkim pristupom organizaciji znanja koja se temelji na razotkrivanju epistemologija (plural) ili svjetonazora raznolikih skupina ljudi. Prema tome pogledu sustavi za organizaciju znanja nužno nude tek jedan od relevantnih pogleda na konceptualnu strukturu ljudskog znanja. Paralelno mogu postojati različiti jednako vrijedni sustavi za organizaciju znanja koji na različit način strukturiraju ljudsko znanje ili neki dio tog znanja. Smiraglia (2015) ističe da je zadaća organizacije znanja prema tome opis multiplih svjetonazorskih pozicija koja služe kao polazišta za organizaciju znanja te omogućiti interoperabilnost rezultantnih sustava osmišljavanjem i otkrivanjem tehnika za njihovu koordinaciju. Postmoderni temelj analize domene prema tom se autoru razotkriva u fokusu na diskurzivne zajednice i metodološkom osloncu na teoriju djelovanja (engl. activity theory) jer se znanje tretira kao rezultat djelovanja nekog diskursa (ibid.). Jens-Erik Mai (1999) tvrdi da su tradicionalne teorije klasifikacije, a time i sustavi koji su ih koristili kao temelj, odraz modernističkog pristupa klasifikaciji. Takva klasifikacija tretira sustave za organizaciju znanja kao objektivne i epistemološki neutralne opise nekog već postojećeg univerzuma povezanog znanja kojeg klasifikacija mora odražavati što je bliže moguće (ibid.). Prema Latouru (1991, kod ibid.) moderna znanost s jedne strane vidi prirodni svijet odvojen od čovjeka i ideja, objekata i stvari koje je stvorio, dok je zadatak znanosti razotkriti zakonitosti prirodnog svijeta i opisati ga onakvim kakav jest. $\mathrm{S}$ druge strane, pak tvrdi da moderna znanost polazi i od druge oprečne pretpostavke o tome da su prirodni svijet i svijet ideja međusobno povezani i mogu se međusobno prevoditi i time objasniti (Latour, 1991 kod ibid.). Mai (1999) tvrdi da se ta kontradikcija može pronaći i u tradicionalnim sustavima za organizaciju znanja jer se temelji na iluziji o tome da klasifikacije vjerno reprezentiraju prirodni poredak stvari koji postoji neovisno od čovjeka, dok istovremeno pokušavaju reprezentirati znanje neovisno o područjima u kojima nastaju oslonjeni samo na klasifikacijske tehnike i standarde pa tvore poopćene modele pojedinih domena (znanstvenog) znanja koje nisu utemeljene na analizi društvenog konteksta pojedinačnih domena i ljudi koji 
im pripadaju. Postmoderno stajalište utemeljeno je u pretpostavkama da ne postoji niti jedan zajednički nazivnik s obzirom na koji bismo mogli razumjeti svijet na jedinstven način te da svim idejama i mislima prethodi jezik (ibid.). Prema tome stajalištu sve činjenice $\mathrm{i}$ istine društvene su konstrukcije (ibid.). Klasifikacija u postmodernom smislu stoga nije opis, već način konstitucije svijeta čije kategorije ovise o povijesnom, društvenom i kulturnom kontekstu u kojem nastaju (ibid.).

Sumativno, od kakve onda slike realiteta, znanosti i svijeta polazi analiza domene? Prema Hjørlandu (2003) umjesto racionalističke paradigme da znanost odražava realitet na objektivan i neutralan način, u informacijskim znanostima i organizaciji znanja primjerenija je paradigma pragmatizma prema kojem produkti znanosti (znanstveni koncepti i teorije) čine tek reprezentaciju realiteta i služe kao korisni alati za neke specifične ljudske svrhe kao što je npr. sistematično razumijevanje svijeta i njegove povijesti. Polazeći od teorije društvenog konstruktivizma i metoda poput analize diskursa analiza domene naglašava važnost kulturalnog iskustva te izbjegava univerzalistička objašnjenja proteklih razdoblja.

Analizi domene predbacuje se da fokus na svrhu i funkciju neke organizacije znanja čini rezultantne sustave tek relativističkim društvenim konstrukcijama. Dapače, i sam Hjørland (2003) priznaje da to polazište čini pragmatističku klasifikaciju kritičkom i političnom. Ipak, smatra da se pragmatistička pozicija koju oblikuje ne može odbaciti kao zagovor relativizma. Naime, taj je pristup utemeljio u tzv. pragmatističkom realizmu prema kojem se organizacija znanja ne može utemeljiti neovisno od postojećih teorijskih i empirijskih argumenata, no tvrdi da se niti jedan izolirani dokaz ne može razmatrati odvojeno od ljudskih ciljeva i aktivnosti (ibid.). Time se na klasifikaciju nužno mora gledati kao na alat namijenjen nekoj isključivo ljudskoj svrsi (ibid.). Prema tome klasifikacija ovisi o pogodnostima, ekonomičnosti i učinkovitosti s obzirom na specifične svrhe koje se njome želi ostvariti (Dewey, 1948 kod ibid.), no u pojašnjenju međuodnosa empiricističkog, racionalističkog, historicističkog i pragmatističkog temelja znanstvenih i bibliografskih klasifikacija svakome od njih predbacuje zaključke prethodećih ili kasnijih pristupa: „Svaki empirijski postupak mora uključivati vrste logike i ne-empirijskih dokaza. Sva pravila moraju se odnositi na neku empirijsku stvarnost. Sve empirijske $i$ racionalne metode moraju se temeljiti na prethodnim tumačenjima $i$ značenjima koja se prenose jezikom i kulturnim produktima. Sve vrste pragmatizma ograničene su uzusima stvarnog svijeta na temelju empirijskih dokaza.“ (ibid., str. 107). 
U okviru opisane konstrukcije metodološkog obrasca analize domene Hjørland (2002; Smiraglia, 2015) razvija jedanaest vrsta metodoloških pristupa ili tehnika za analizu domene koji uključuju izradu različitih vrsta predmetnih pomagala, specijalne klasifikacije, informetrijske i epistemološke studije, analize žanra itd. 


\section{Revitalizacija univerzalizma i kritike disciplinarnosti u organizaciji znanja}

U tijeku razvoja analize domene pojavljuju se i novi zagovornici univerzalističkih pristupa organizaciji znanja i to primarno u području klasifikacije. Posljednji univerzalistički projekti koji su uslijed akumuliranih kritika napustili fokus na disciplinarnu perspektivu u reprezentaciji znanja ostaju nedovršeni (poput npr. sustava PRECIS). Claudio Gnoli i Rick Szostak (2016) predstavnici su stajališta da se reprezentacija znanja ne bi trebala ograničavati na prikaz dinamike jedne domene već na interakciju više domena znanja te da univerzalistički projekt organizacije znanja nije propao već da je tek privremeno bio napušten jer je područje refokusiralo interese pod utjecajem postmodernog tretmana zabilježenog znanja. Za razliku od domensko specifičnog pristupa Szostak i Gnoli svoj pristup imenuju interdisciplinarnom organizacijom znanja koji supsumira i transdisciplinarne pristupe. Zanimljivo je da i Hjørland i Albrechtsen (1995) u svome programatskom članku također uočavaju transdisciplinarne tendencije u znanosti i razvoj transdisciplinarno usmjerenih područja no tu pojavu objašnjavaju u odnosu na vlastiti domensko specifični pristup.

Uzevši u obzir povijesni razvoj područja organizacije znanja moguće je uočiti dva teorijska trenda. Onaj, danas predvođen Gnolijem i Szostakom, ontološki i onaj epistemološki, predvođen Brigerom Hjørlandom. Oba pristupa imaju određene prednosti koje reafirmiraju područje organizacije znanja kao produktivno područje znanstvenog istraživanja. Ako pak ove trendove suprotstavimo neizbježno je uočiti određene nedostatke pojedinog pristupa, kao i momente konflikta između njih. Prema Gnoliju (2008b) zagovornici jedne i druge pozicije slažu se da je između ova dva pristupa nužna rekoncilijacija jer oba pridonose konkretizaciji mnogih aspekata organizacije znanja, ali i informacijskih znanosti u cjelini (npr. njenih metoda, unificirajućih teorija (cf. Hofkirchner, 2010) njenih predmeta, granica i strukture područja, vrste znanja koju producira unutar sebe, ali i na razini multi-, inter- $\mathrm{i}$ transdisciplinarnih suradnji). Glavni moment kritike koju donosi Gnolijev i Szostakov pristup utemeljen je u tumačenju da epistemološki, domensko-analitički, historicistički, pragmatistički i hermeneutički pristupi postavljanjem diskurzivnih zajednica u središte svoga razmatranja, uzrokuju shvaćanje disciplina isključivo u granicama njihova klasičnog određenja.

Za Gnolija i Szostaka (2014) jedan je od glavnih argumenata za revitalizaciju univerzalističkih pristupa problem interoperabilnosti koji analiza domene ne može samostalno razriješiti. Njihova percepcija univerzalizma u klasifikaciji svodi se minimalno na zahtjev za 
harmonizacijom otkrivenih epistemoloških različitosti pojedinih domena u jednu koherentnu strukturu čak i ako takva struktura neće biti savršena (ibid.). Univerzalizam vide kao ideal kojemu treba stremiti, no posebno ističu svijest o raznim kulturnim pristranostima kojima su obilovali tradicionalni univerzalistički sustavi (ibid.). Prema Gnoliju i Szostaku (ibid., str. 1), tradicionalni sustavi „privilegiraju perspektivu zapadnjačkih, kršćanskih, bjelačkih, muških $i$ heteroseksualnih korisnika" kojoj se novi sustavi trebaju suprotstaviti inkorporacijom tzv. kulturnog jamstva kojeg je Claire Beghtol definirala još 1986. godine (cf. Beghtol, 1986a). Navode da je novi fokus na taksonomije i ontologije za tvorbu semantičkog Weba priziv stare potrebe za klasifikacijom i to onom univerzalističkom te smatraju da se interoperabilnost i u tom kontekstu mora postići, ne samo na tehničkoj, standardizacijskoj ili sintaksnoj razini, već i na konceptualnoj razini (Gnoli i Szostaka, 2014).

Iako zagovaraju univerzalizam u klasifikaciji Gnoli i Szostak u kontekstu osiguranja interoperabilnosti izražavaju snažne kritike na račun tradicionalnih sustava zbog njihovog disciplinarnog temelja koji je očigledan u samim strukturama široko rasprostranjenih sustava za organizaciju znanja poput Univerzalne decimalne klasifikacije (UDK). Gnoli (2011, str. 2) pojašnjava: „Tradicionalni sustavi poput bibliografskih klasifikacija često su disciplinarno utemeljeni, što znači da su primarno strukturirani prema epistemološkoj dimenziji: znanje je prvo podijeljeno s obzirom na pogled na svijet, a ne prema njegovom objektivnom sadržaju. Klasificirati dokument pod 500 „,čiste znanosti“ u Deweyevoj decimalnoj klasifikaciji (DDK), znači da dokument sadrži pogled na svijet s obzirom na određenu fundamentalnu perspektivu, onu znanstvenu, za razliku od alternativnih perspektiva poput estetičkih, historijskih, filozofskih ili religijskih“.

Ovaj se set kritika može pratiti još od sedamdesetih godina kada primjerice Foskett kritizira ne-organiziranost predmetnih područja nazivajući ih povijesnim olupinama ili krhotinama čija je međupovezanost neustanovljena (CRG, 1961). CRG u okviru rasprave o disciplinarnosti postavlja pitanje što uopće čini neko predmetno područje (ibid.). Postignut je konsenzus okupljenih stručnjaka da ne postoje trajne prirodne podjele u univerzumu znanja koje bi tvorile omeđena predmetna područja (ibid.). CRG polazi od pretpostavke da su predmetna područja kompleksi koji su nastali kao skup elementarnih stvari i aktivnosti na temelju koji se pojedino područje može opisati (ibid.). Stoga, smatra li su da predmetna područja čine arbitrarna grupiranja pojedinih kategorija na pojedinim razinama integracije te da to upućuje 
na zaključak da su discipline privremene i promjenjive kategorije neomeđenog opsega $u$ stalnom stanju razvoja (ibid.).

Nešto kasnije, u svome članku o terminologiji predmetnih područja Dahlberg (1975) zamjećuje da se čovječanstvo kontinuirano kreće prema bavljenju sve složenijim konceptima i obrascima mišljenja te proziva to ontogenetičkom i filogenetičkom karakteristikom čovjeka. Takav razvoj događaja locira u smjeni naziva, definicija i opsega predmetnih područja koje se sve više specijaliziraju u poddiscipline (ibid.). Ta specijalizacija vodi prema tzv. aspektnoj znanosti pri čemu se znanstvenici okupljaju oko pojedinih istraživačkih fenomena kako bi se mogli baviti njihovim različitim aspektima (ibid.). Kao primjer navodi fenomen „tla“ i znanost koja se njome do sada isključivo bavila tj. pedologiju (ibid.). Za razliku od toga jedinstvenoga polja unutar kojeg se istraživao fenomen tla, tada, prema Dahlberg, dolazi do usitnjavanja polja u aspektna-područja pa se tako pojavljuju: fizika tla, mehanika tla, kemija tla, biokemija tla itd. (ibid.). Za klasifikaciju to znači da će se za mnoga polja i mnoge fenomene svakodnevno formirati istoznačnice ili bliskoznačnice te da će pristup informacijama biti znatno otežan i krnj. Ipak, ističe, prepoznavanje novoga predmetnoga područja ne ovisi samo o terminološkoj ${ }^{30}$ razini i definicijama naziva novostvorenih poddisciplina već i o drugim elementima od kojih su neki i društvene naravi. Prema definiciji Međunarodne federacije za informacije i dokumentaciju (ibid., str. 32) predmetno područje je „prepoznat skup aktivnosti oko jednog ili više predmeta čija je prepoznatljivost utvrđena kriterijima poput

- broja ljudi aktivnih u području

- broja dokumenata koji se produciraju

- postojanju ili uspostavljanju specijalističke terminologije područja.“

Stoga, Dahlberg (ibid., str. 33) komentira da se predmetno područje može odrediti i kao „,kulturološki fenomen koji izrasta iz praktičnih, intelektualnih i drugih mentalnih aktivnosti o istraživanju i promjenama u prirodi i prirodnim fenomenima kao i emanacijama i produktima

\footnotetext{
${ }^{30}$ Dahlberg je specifično zainteresirana za terminološko-konceptnu razinu ove rasprave. U svome istraživanju nastoji mapirati i stvoriti tipologiju vrsta novih područja koja se pojavljuju 70 -ih godina prošlog stoljeća. Prepoznaje i tvrdi da se u njemačkom govornom području nazivi poddisciplina organiziraju u tri kategorije: 1 . objekt ili fenomen + naziv discipline (npr. fizika tla), 2. pridjev + disciplina (npr. kemijska tehnologija, biološka kemija, ili pak integrativna bioetika ili primijenjena etika), 3. disciplina - specifikacija (npr. sociologija obrazovanja).
} 
koji su rezultat aktivnosti čovjeka i društva kao takvih." Područja se počinju interdisciplinarno kombinirati, a mjesto susreta nisu same discipline već fenomeni kojima se bave. ${ }^{31}$

I drugi, suvremeniji autori pridružuju se evokaciji kritika disciplinarnosti iz sedamdesetih godina pa tako Mauri Kaipainen i Antti Hautamäki (2011) disciplinarno zasnivanje organizacije znanja kritiziraju zbog njene jednodimenzionalnosti tj. monoperspektivnosti, a izvor problema povezuju uz navike disciplina i struka koje koriste sustave za organizaciju znanja. Kako navode, iako ih koriste, istovremeno ne dovode u pitanje njihovo utemeljenje u isključivo jednoj konceptualnoj tj. disciplinarnoj strukturi. Prema ovim autorima, svaki se korpus informacija može klasificirati, kategorizirati i konceptualizirati iz niza alternativnih perspektiva. Stoga, ističu da same strukture sustava ne mogu biti neutralne već promoviraju specifične znanstvene, ideološke, pedagoške ili estetičke paradigme s njima pripadajućim setovima vrijednosti i prioritetima. Na temelju toga ocrtava se potreba za informacijskim sustavima koji nisu utemeljeni na jednoj ontologiji i gdje koncepti nisu čvrsto predodređeni ontološkim pretpostavkama, već je njihovo određenje relativno s obzirom na perspektivu razmatranja.

Antonio García Gutiérrez (2014) disciplinarni monoperspektivizam sustava za organizaciju znanja prvenstveno uočava u tradicionalnim klasifikacijskim sustavima čiju praksu klasifikacije, zbog njihovog pozitivističkog i redukcionističkog temelja, proziva isključujućom epistemološkom operacijom kategorizacije gdje se oblikovanjem strogo disciplinarno utemeljenih i zatvorenih koncepata dogmatizam razotkriva kao krajnja intencija takve kategorizacije. Tradicionalne sustave karakterizira kao instrumente opresije i dominacije u obliku kulturne i kognitivne kolonizacije. Zaključuje da bismo trebali nastojati deklasificirati kompleksnost svijeta što bi značilo da je postupak organizacije znanja potrebno otvoriti čak i kontradikcijama kako bismo omogućili reprezentaciju logički, kulturno, društveno, politički i kognitivno pluralnog svijeta. Kontradikcija je za Garciju bazični izvor svakodnevnog i pragmatičkog usvajanja svijeta te izvor snažnih intuicija koje je nemoguće reprezentirati u tradicionalnim sustavima za organizaciju znanja. Dihotomnu logiku klasifikacije kako bi se odredilo ono pravo i krivo; pravo važenja i primat pojedinoga gledišta, trebali bismo, prema Garciji, zamijeniti logikom epistemičkog pluralizma.

\footnotetext{
${ }^{31}$ Zanimljivo je da Dahlberg ovdje ne opisuje i društvene znanosti i društvene fenomene te ne objašnjava je li dinamika specijalizacije u poddisicpline trend koji je prisutan i u društvenim znanostima.
} 
U recentnoj knjizi Interdisciplinarna organizacija znanja Ricka Szostaka i suradnika (2016) također se ističe da tradicionalni sustavi za organizaciju znanja reprezentiraju modernu strukturu znanosti i njeno čvrsto disciplinarno utemeljenje. Kao i sva druga pomagala, sustavi za organizaciju znanja podržavali su i nastoje podržavati aktualni opseg potreba znanstvenih i stručnih pothvata, stoga i sami sustavi odražavaju visoki stupanj specijalizacije i redukcionizma karakterističnog za pozitivističko utemeljenje moderne znanosti. Koncepti koji se organiziraju smatraju se zatvorenim entitetima s jasnim granicama i iznimkama. Stoga, ne treba čuditi da je njihova struktura strogo hijerarhijska, a stvaranje reda utemeljeno na binarnom i fiksiranom razumijevanju koncepta koncepta koji u praksi postaje autorizirana informacija i (jedina) relevantna istina.

Važno je također napomenuti i da je sam pojam disciplinarnosti opterećen konceptualizacijama koje potječu iz raznih misaonih tradicija (Sugimoto i Weingart, 2015). Tako se na kognitivnoj razini discipline može razmatrati kao jedinice koherentno organiziranog intelektualnog sadržaja; na društvenoj kao zajednicu prepoznatih istraživača ili organiziranu društvenu grupaciju; na komunikacijskoj kao jedinice koje koriste specijalizirane terminologije i tehnički rječnik prilagođen njihovom objektu istraživanja; na strukturalnoj kao specifično gledište ili homogenu domenu znanja koju je moguće jasno razlučiti prema njenim konstitutivnim elementima, teorijama i metodologijama; na povijesnoj kao specifičnu historijsku intelektualnu tradiciju koja prolazi kroz razvojne faze; te kao institucionalizirani oblik znanstveno-stručnog djelovanja (ibid.).

Zametke alternativnih pristupa možemo vidjeti i u samoj teoriji analize domene. Utemeljen u socijalnoj epistemologiji, pristup analize domene postulira da indeksiranje nekoga dokumenta mora odražavati potrebe neke grupe korisnika ili neke idealne svrhe. Prema tom razumijevanju, nije moguće jednom zauvijek dodijeliti nekome dokumentu standardizirani opis i očekivati da će on biti dovoljan za sve ciljne skupine. Dapače, za različita gledišta potrebno je osigurati različite sustave organizacije, pri čemu se analiza domene usmjerava na kolektivne poglede skupina korisnika sustava za organizaciju znanja (Hjørland, 2008). Važno je istaknuti da analiza domene tako nadilazi subjektivnost individualnih gledišta i utoliko se razlikuje od subjektivnosti kakva je prisutna u pristupima temeljenim na korisničkom označivanju. Kao što zaključuje Sonja Špiranec (2014, str. 12): „Tek [se] s korisničkim označivanjem dokraja [...] razvija potpuno subjektivni pristup označivanju, visoke granularnosti, na razini pojedinog korisnika i njegovih individualnih osobnih potreba te je 
moguće zaključiti da korisničko označivanje u ovom trenutku predstavlja krajnji i potpuni oblik subjektivnog označivanja“. Pristup analize domene, gledišta identificira kao raznolika filozofska stajališta koja definiraju zasebne kriterije relevantnosti, informacijske potrebe i kriterije za organizaciju znanja neovisno o razmatranom problemu (Hjørland, 2008, str. 95). Ishodišta potrebe takvoga pristupa Hjørland i Albrechtsen (1995) lociraju u „transdisciplinarnim tendencijama u razumijevanju znanja“ (ibid., str. 404) koje naglašavaju „društvenu, ekološku i na sadržaje orijentiranu narav znanja“ (ibid., str. 404). U okviru zagovora informacijske znanosti kao društvene, a ne kognitivističke znanosti, predstavljaju razvoj transdisciplinarnog polazišta u različitim područjima u kojima se na ljudsko znanje gleda kao na organičko, kontekstualno, sociokulturno i specifično za pojedinu domenu znanja. Informacijske znanosti, a onda i organizacija znanja, trebale bi se usmjeriti na domene znanja u kojima pojedinci sudjeluju kao akteri i članovi djelatnih grupa, disciplina te misaonih i diskurzivnih zajednica uključivo s njihovim pogledima na svijet, individualnom strukturom znanja, pristranostima, subjektivnim kriterijima relevantnosti, partikularnim kognitivnim stilovima itd. (ibid., str. 409). Važno je naglasiti da niti Gnoli niti Szostak u okviru vlastitih pokušaja ne odustaju od tih tekovina analize domene i traže spajanje kognitivističkih i sociokulturnih pristupa u novi treći put za organizaciju znanja.

María J. López-Huertas (2015) deset godina nakon programatskog članka o analizi domene na temelju razvoja koncepta zaključuje da je teorija analize domene ipak bila namijenjena ponajprije disciplinarnim domenama. $U$ svome članku razrađuje razlike $u$ analizi disciplinarnih i interdisciplinarnih domena koje proizlaze iz naravi interdisciplinarnog znanja. Zaključuje kako je potrebno proširiti definiciju analize domene znanja, „kao misaonih ili diskurzivnih zajednica koje sudjeluju u društvenoj podjeli rada“, (Hjørland i Albrechtsen, 1995, str. 400) prema interdisciplinarnim i transdisciplinarnim suradnjama koje su rezultat „,nove produkcije znanja kao izraz procesa integracije i interakcije raznolikih specijalnosti usmjerenih na istraživačke objekte usko povezane s društvom“ (López-Huertas, 2015, str. 574). Četiri karakteristike interdisciplinarnog znanja koje prema López-Huertas utemeljuju potrebu proširenja definicije jesu: na razini produkcije potreba interakcije i integracije znanja između specijalnosti; na razini vrste znanja zahtjev za korištenjem izvanznanstvenih izvora znanja u interdisciplinarnim istraživanjima; na razini aktera zahtjev za uključivanjem osoba iz neakademskih miljea $\mathrm{u}$ interdisciplinarne istraživačke projekte; te na razini porijekla istraživačkih problema kao proširenje istraživačkog interesa na probleme zajednice i 
pragmatičkog društvenog poslanja sveučilišta što se odražava u odabiru, u odnosu na znanost, egzogenih istraživačkih problema.

Vidljivo je da kao alternativu disciplinarnom utemeljenju organizacije znanja autori razmatraju interdisciplinarne pristupe te da $\mathrm{u}$ njih supsumiraju $\mathrm{i}$ one transdisciplinarne. Potrebu podrške transdisciplinarnim potrebama u otkrivanju znanja zamijetili su mnogi od spomenutih autora. No, dok se naglasak ponegdje stavlja na interdisciplinarnost (npr. LópezHuertas, 2015; Szostak, Gnoli i Lopez- Huertas, 2016), drugi autori, oslanjajući se na isti problemski prostor, kao polazište za definiciju problema naglašavaju transdisciplinarnost (npr. Cameron i Mengler, 2009; García Gutiérrez, 2011). Dapače, Szostak i suradnici (2016) smatraju kako su izazovi interdisciplinarnosti i transdisciplinarnosti u organizaciji znanja podjednaki jer interdisciplinarnost danas ne pokušava dovesti u interakciju samo disciplinarne već i one nedisciplinarne perspektive. S obzirom na to ističu da sustave treba osmisliti tako da istovremeno podržavaju potrebe korisnika iz akademskih i neakademskih krugova.

Prijedlog konkretnog pristupa opisanoj organizaciji znanja za sada je najdetaljnije opisan u recentnoj publikaciji Ricka Szostaka i suradnika (2016) Interdisciplinarna organizacija znanja, a pokušaj njegova ostvarenja sadržan u Klasifikaciji integrativnih razina (KIR). KIR je tekući istraživački projekt kojeg provodi internacionalni tim predvođen Claudiom Gnolijem, a čija se ideja temelji na prethodno izloženoj kritici disciplinarnog utemeljenja tradicionalnih sustava za organizaciju znanja, prednostima njihovog ontološkog zasnivanja i fasetnog tretiranja koncepta perspektive. Za razliku od epistemološki strukturiranih sustava poput UDK ili DDC koji reprezentiraju disciplinarno znanje, ontološki strukturirani sustavi temelje se na klasifikaciji fenomena tj. stvarnih objekata koji postoje u svijetu koji percipiramo. 


\section{Klasifikacija fenomena}

Članovi CRG-a već 1958. godine (CRG, 1957) ističu problem reprezentacije tradicionalnih disciplina u uvjetima njihova sve većeg preklapanja. I Kyle u članku o klasifikaciji u društvenim znanostima ističe potrebu za pronalaskom zajedničkih termina za fenomene koji su različito imenovani u različitim disciplinama (Kyle, 1958) pojašnjavajući da klasifikacija prema tome treba nadići reprezentaciju znanja sukladno specifičnim obrascima mišljenja pojedine discipline.

Interes za univerzalne klasifikacijske sheme obnavlja se početkom 2000-ih godina kada Gnoli, u članku iz 2004. godine, pragmatizmu domensko-specifičnih pristupa suprotstavlja ono što proziva naturalističkim pristupom. Prema tome pristupu, koji bi se također mogao opisati i kao holistički pristup, znanje se tumači kao dio jedne cjeline tj. opće reprezentacije svijeta. Za razliku od tradicionalističkih pristupa ono se ne tumači kao konačno, već kao znanje u stalnom razvoju koje nikada ne dostiže svoj konačni oblik pri čemu ne postoje jasne granice između disciplina, a pojedine domene nije moguće izolirati i razmatrati kao sasvim odvojene od sveg drugog znanja (Gnoli, 2004a). Temeljna je distinkcija između naturalističkog i pragmatističkog pristupa organizaciji znanja već spomenuti naglasak na ontološkom, umjesto epistemološkog zasnivanja sustava. $\mathrm{Na}$ razini epistemologije naturalistički pristup oslanja se na argument hipotetičkog realizma tj. da se osnovne kategorije percepcije i mišljenja temelje na svojstvima stvarnog svijeta, pri čemu znanje o njemu nikada ne postaje savršeno i potpuno, ali se smatra dovoljno snažnim utemeljenjem ljudske percepcije svijeta (ibid.). Slijedeći logiku toga argumenta, klasifikacija se ne bavi prikazivanjem svijeta onako kako ga je razotkrila i objasnila znanost kao što je to bio slučaj u tradicionalnim pristupima, već organizacijom mentalnih entiteta i koncepata (ibid.). Pritom treba imati na umu da će se određeni aspekti realiteta i dalje dominantno reprezentirati prema stanju (prirodno)znanstvene spoznaje te da će se ta reprezentacija uvijek tretirati kao falsikabilna i kao interpretacija znanstvenog konsenzusa kreatora klasifikacije. Iako i sam Hjørland kaže da nema analize domene bez relacije prema empirijskom, Gnoli vlastito teorijsko utemeljenje klasifikacije crpi iz kritike domensko specifičnih pristupa kao zagovora kulturnog relativizma koje vidi kao one koji obgrljuju kulturološke pristranosti koje proizlaze iz konteksta nastanka pojedinog sustava za organizaciju znanja (Gnoli, 2008b). Gnolijevom se pristupu ne može prebaciti kritika racionalističkog pristupa bibliografskim klasifikacijama da je fasetna analiza koju primjenjuje temeljena na nepromjenjivim i vječnim kategorijama jer Gnoli i sam priznaje ulogu i dinamiku razvoja znanstvenih paradigmi. Njegova je klasifikacija 
stoga osmišljena kao projekt u stalnom razvoju, a svaka klasa tentativna je reprezentacija konsenzualnih i aktualnih kanona znanja.

Prema Hjørlandu (2003) nekoliko je temeljnih načina za određivanje mjesta koncepata u klasifikaciji. To mogu biti naprosto logičke ili jezične relacije (npr. opće-posebno: neka specifična institucija jedna je od institucija), ljudske konvencije i dogovori (npr. Piranski zaljev je teritorij koji bi mogao mijenjati pripadnost pojedinoj državi), način organizacije sveučilišta (npr. psihologija može biti smatrana dijelom prirodnih, humanističkih ili društvenih znanosti ovisno o profesionalnim interesima i istraživačkim tradicijama pojedinih institucija), teorija evolucije, empirijske generalizacije ili ad hoc svrhovite i privremene definicije odnosa među konceptima. Kod Gnolija će se ontološko zasnivanje klasifikacije ponajprije očitovati $\mathrm{u}$ primjeni već spomenute teorije integrativnih razina, no tek će $u$ Klasifikaciji integrativnih razina zaživjeti kao osnova jednog cjelovitog sustava za organizaciju znanja. Time on zapravo nastavlja onaj tip univerzalističkih projekata koje su započeli autori poput Ingetraut Dahlberg i Dereka Austina nastavljajući tradiciju koja koncepte uzima kao osnovnu jedinicu sustava za organizaciju znanja. Gnoli (2016) ističe da je njegov pristup različit $\mathrm{u}$ odnosu na aktualnu paradigmu koja sustave za pretraživanje informacija temelji na prirodnom jeziku i pisanoj riječi koja nije uvijek direktno podudarna s konceptima (cf. ibid.). Naime, smatra da je iluzorno mišljenje stručnjaka koji sistematsko sortiranje koncepata odbacuju kao bespotrebno u digitalnom kontekstu jer sistematski prikaz i dalje ima funkciju onda kada je neki popis potrebno organizirati kako bi bio jasniji na kognitivnoj razini (ibid.). Ako se u tim situacijama oslonimo na arbitrarne definicije kategorija riskiramo da se zabilježeno znanje povezuje na nejasnim temeljima što može štetiti kvaliteti obrazovanja i informiranja o pojedinim temama, ali i znanstvenom radu ponajprije na razini vremena koje je potrebno utrošiti da bi se uspostavilo domensko znanje i domenski kapacitet znanstvenika. Slično mišljenje pronalazimo i kod Henryja E. Blissa koji smatra da je nemoguće odrediti sadržaj nekog dokumenta bez da se referiramo na neku sistematsku strukturu raznovrsnog znanja (engl. manifold knowledge) te da to predstavlja tek "iluziju predmetnog indeksiranja" (Kleineberg, 2014). Pozivajući se na Blissov primjer, Kleineberg (2014) ističe da je argument o iluzornosti takvog pristupa moguće primijeniti i na klasifikaciju epistemičkih okvira ili kontekstno situiranih gledišta prisutnih u nekome dokumentu te smatra da se klasifikacija perspektiva koje se želi "suočiti s izazovom epistemičkog pluralizma bez da zapadne u epistemički relativizam, mora moći odrediti spram svih mogućih epistemičkih okvira u svim disciplinama, domenama ili kulturama kako u sinkronijskom tako $i$ 
dijakronijskom smislu" (ibid., str. 81). U radu iz 2014. godine o unificiranoj teoriji informacija Claudio Gnoli i Ricardo Ridi zaključuju da teoriju integrativnih razina, ali niti jednu drugu teoriju najvjerojatnije nije moguće dokazati, ali da su njihova moć pojašnjenja i unutarnja konzistencija dovoljne da budu dio učinkovitog rješenja (Gnoli, Ridi, 2014). Takvo određenje poima klasifikaciju nužno kao heuristiku, a Gnoli taj pristup proziva još i hermeneutičkim kao onaj koji "promovira set korisnih interpretacija stvarnosti bez da tvrdi da je obuhvatio njenu genuinu esenciju jednom i zauvijek, te istovremeno umanjuje značaj pitanja o broju razina u koje bi realnost trebala biti objektivno strukturirana" (Gnoli, 2017b, str. 454). Nedvojbeno je da je Klasifikacija integrativnih razina izrazito inspirirana $u$ filozofskoj ontologiji ta da pojmovne kategorije i distinkcije toga područja ne smatra trivijalnim, no svrha klasifikacije nije iznaći metafizičko objašnjenje o naravi svijeta. Naime, naturalistički pristup želi uspostaviti prirodnu klasifikaciju tj. klasifikaciju čije se kategorije temelje "na onim karakteristikama koje su se pokazale kao učinkovite za pojašnjenje $i$ generalizaciju širokog spektra različitosti” (Gnoli, 2017a, str. 38). Ipak, Gnoli ističe da je tehničko ili umjetno uspostavljanje klasifikacije neizbježno zbog nemogućnosti potpunog određenja onoga što je prirodno, no pojašnjava da bit leži u razlici intencije tvorenja umjetne naspram prirodne klasifikacije (ibid.). Naturalizam je prema tome prije svega stremljenje da klasifikacija identificira fenomene prema zamjetljivim karakteristikama iako to ponekad nije dovoljno za konstituciju funkcionirajućeg i primjenjivog sustava ${ }^{32}$.

Prednost teorije integrativnih razina Gnoli vidi u mogućnosti njihove primjene na fenomene umjesto disciplina što će uspostaviti mjesto jedinstvene definicije u Farradaneovom smislu. Klasificirani fenomen neće se nalaziti u nekoliko disciplina već ga se kvalificira fasetama koje ukazuju na pojedinačna disciplinarna razmatranja predmetne klase fenomena (Gnoli, 2004a; Gnoli, 2007). Upravo je to obilježje klasifikacije fenomena ono koje će postati ključna prednost za interdisciplinarnu i transdisciplinarnu organizaciju znanja.

Klasifikacije fenomena počinju razvijati i drugi znanstvenici u području organizacije znanja pa tako Rick Szostak započinje rad na Klasifikaciji osnovnih koncepata (engl. Basic Concepts Classification), no kasnije usporava rad na tome projektu jer se pridružuje Gnoliju u radu na razvoju Klasifikacije integrativnih razina. Prva verzija te klasifikacije objavljena je 2011. godine i do sada je objavljeno nekoliko nadogradnji. Klasifikaciju razvija međunarodni tim

\footnotetext{
${ }^{32}$ Neka su određenja fenomena u Klasifiakciji integrativnih razina provizorna jer su definirana u odnosu na neke nepotvrđene teorije te treba imati na umu da će se definicije tih fenomena mijenjati kako teorije postanu jasnije (Szostak, 2015).
} 
stručnjaka i istraživača pretežito europskog porijekla. Strukturalno je klasifikacija integrativnih razina od svoje druge verzije reprezentirana u SKOS formatu ${ }^{33}$ koji omogućava izražavanje klasifikacije u RDF/XML sintaksi pa je time prilagođena zahtjevima semantičkog weba i iskoristiva ne samo u analognom već i digitalnom kontekstu (Gnoli et al., 2011).

Kako bi olakšao razumijevanje osnovnih značajki klasifikacije integrativnih razina Gnoli od 2016. do 2018. godine objavljuje članak Klasificiranje fenomena u četiri dijela (1. Dimenzije, 2. Tipovi i razine, 3. Fasete, 4. Teme i reme). Gnoli klasifikaciju fenomena smještava u cjeloviti okvir dimenzija organizacije znanja. Pojam dimenzija organizacije znanja odnosi se na razinu razmatranja univerzuma znanja pri čemu se svaka dimenzija usmjerava na jedan specifični predmet razmatranja međusobno povezan s prethodnim i idućim razinama. Prema Gnoliju organizacija znanja indirektno je utemeljena u stvarnosti samoj (dimenzija $\alpha$ ), no onome koji organizira znanje ta je dimenzija nedostupna pa se njeni postupci mogu odnositi tek na razinu posredovanu ljudskom percepcijom tj. na razinu fenomena (dimenzija $\beta$ ) (Gnoli, 2016). Te prve dvije dimenzije Gnoli uspoređuje s oprekom između noumenona i phenomenona kako se s njome susrećemo u filozofiji Immanuela Kanta i naglašava da se pojam fenomena koristi bez neke osobite relacije prema filozofskom učenju fenomenologije (ibid.). U tradicionalnom smislu organizacija znanja najčešće se bavila dimenzijom koja se odnosi na perspektive tj. na različite načine razmatranja i definicije pojedinog fenomena (dimenzija $\gamma$ ). Definicijom ove dimenzije Gnoli ukazuje na srodnost brojnih pristupa $\mathrm{u}$ organizaciji znanja jer ukazuje na to da su se znanstvenici u području bavili perspektivama i onda kada su govorili o domenama znanja, aspektima, gledištima, aktivnostima itd. (ibid.). Dimenzija medija kao nositelja zabilježenog znanja očituje se kao iduća dimenzija $\delta$ tj. dimenzija dokumenata, a nju prirodno slijedi predmetno usmjerenje organizacije znanja na zbirke (dimenzija $\varepsilon$ ), informacijske potrebe (dimenzija $\zeta$ ) i konačno ljude kao korisnike i tvoritelje sustava za organizaciju znanja (dimenzija $\eta$ ) (ibid.).

Gnoli (2016) pojašnjava da su različiti pristupi organizaciji znanja razvijani kroz povijest uvijek važnost pridavali nekoj od ovih dimenzija pa će tako pristupi usmjereni primjerice na zbirke organizaciju zabilježenog znanja temeljiti na fizičkim uvjetima za smještaj građe koju opisuju (npr. prema veličini polica i formata). U pristupima usmjerenim na dokumente razvijen je koncept literarnog jamstva pa će se predmetna obrada u tim pristupima odnositi samo na one perspektive i fenomene zapravo sadržane $u$ analiziranim dokumentima (ibid.).

\footnotetext{
${ }^{33}$ MARC bibliografski formati smatrali su se neadekvatnim za reprezentaciju fasetnih klasifikacija jer nisu predviđeni za primjenu na sintetičke sustave za organizaciju znanja (Gnoli et al., 2011).
} 
Gnoli (2016) je posebno kritičan prema pristupima usmjerenim na epistemološku dimenziju tj. dimenziju perspektiva $\gamma$. Slično kao i Lopez-Huertas (2015) ističe da je praksa organiziranja znanja primarno prema dimenziji perspektiva dovela do toga da se granice između specijalizacija dodatno produbljuju te da one dovode do toga da korisnici tih specijaliziranih terminologija opetovano djeluju i razmišljaju u zadanim okvirima tih specijalizacija. Kritizira i pasivnu ulogu klasifikatora (Gnoli, 2016) u tom procesu jer klasifikator postaje tek osoba koja novo znanje bilježi u okvirima utabanih podjela bez obzira na posljedice koje nesmotrena praksa klasificiranja može imati u stvarnom svijetu.

Gnolijevo rješenje usmjereno je na fenomene tj. dimenziju $\beta$. Smatra da će se $u$ tako zasnovanim sustavima fenomeni različitih disciplina mnogo lakše ujediniti jer će pripadati istim klasama fenomena te će se notacije tih klasa nalaziti u njihovim notacijama te tako biti ujedinjeno pretražive u sustavima za pretraživanje informacija (ibid.). Posebno je važno istaknuti da same discipline ne nestaju iz sustava baziranim na fenomenima. Naime, mnoge će se discipline moći definirati s obzirom na skupinu fenomena koje proučavaju (ibid.), narav znanja koje produciraju ili opis pripadnosti nekoj specifičnoj zajednici ljudi. Drugim riječima, dobra klasifikacija mora omogućiti iskazivanje predmetnog opisa i s obzirom na druge dimenzije organizacije znanja.

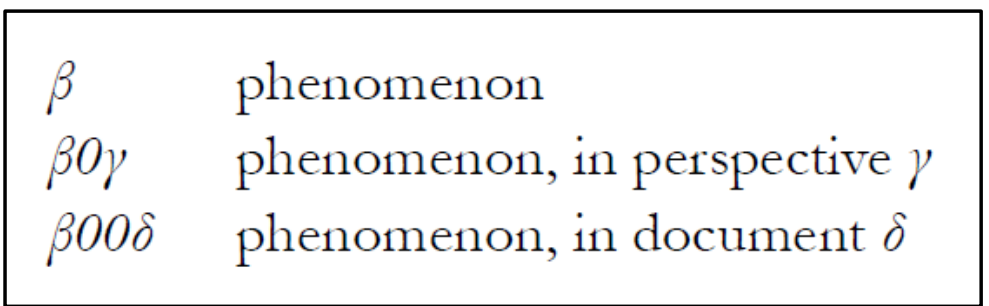

Slika 2. Međuodnos dimenzija organizacije znanja u klasifikaciji fenomena (Gnoli, 2016)

Klasifikacije integrativnih razina klasificira fenomene prema dva temeljna strukturalna principa - vrstama i razinama (Gnoli, 2017a). Pojedinačni identificirani fenomeni organizirani su u klase prema sličnostima koje imaju u odnosu na druge fenomene. Klase se definiraju ekstenzionalno enumeracijom svih pripadajućih fenomena ili intenzionalno s obzirom na karakteristike koje određuju pripadnost fenomena nekoj klasi (ibid.). Različitosti među klasama fenomena utječu na određenje smještaja fenomena prema porastu kompleksnosti sukladno teoriji integrativnih razina i također mogu biti razlog za tvorbu nove klase fenomena kada je distinkcija nekog fenomena značajna (ibid.). U ontološki zasnovanoj klasifikaciji značajno će biti ono što odražava prirodu nekog fenomena (ibid.). 
Klase su u sistematskim klasifikacijama klasično organizirane u nizove fiksnog i uređenog redoslijeda (za razliku od abecednog rasporeda), a svakoj je klasi pridružena notacija u obliku numeričkog ili alfabetskog simbola koji tvori numerički ili alfabetski redoslijed (ibid.). Takva struktura prisutna je i u Klasifikaciji integrativnih razina. Klase mogu imati i podklase koja sadrži koncepte veće specifičnosti koji pripadaju nadređenoj klasi tvoreći tako hijerarhijske lance vrsta i podvrsta koji mogu proizlaziti i svakog elementa nekog niza (ibid.).

Razine $^{34}$ su temeljni princip redanja klasa u Klasifikaciji integrativnih razina. Integrativne razine, razine organizacije ili razine kompleksnosti odnose se na princip redanja koji proizlazi „,iz priznanja da se klase opaženih fenomena, poput životinja, kamenja, pjesama, mogu urediti u serije pri čemu su „, viši“ fenomeni derivirani iz „nižih“ na temelju njihova povijesnog porijekla - ili, općenitije, logičkog prioriteta.“ (ibid., str. 40). Takav princip redanja onemogućuje da primjerice stol prethodi čovjeku koji ga je stvorio ili da atomi dolaze nakon molekula koje su od atoma sazdane. Svaka viša razina sadrži određena svojstva koja nisu bila prisutna na nižim razinama, a ,prijelaz s nižih na više fenomene naziva se emergencijom [... pa tako možemo govoriti o] emergenciji uma u živim bićima“ (ibid., str. 41) itsl. Tako definiranu emergenciju Gnoli modelira u novu vrstu odnosa egzistencijalne ovisnosti između viših i nižih klasa fenomena koja će se očitovati kao fiksno pravilo linearnog nizanja klasa u klasifikaciji integrativnih razina (ibid.). Temeljni principi razlikovanja klasa fenomena njihova su morfologija i filogeneza (ibid.). Riječ je o klasičnim klasifikacijskim principima pri čemu se iz morfoloških karakteristika deriviraju razlike između podvrsta istog fenomena, a iz filogenetičkih pretpostavke redoslijeda njihovog nastanka što utječe na poredak klasa (ibid.).

\footnotetext{
${ }^{34}$ Za povijesni prikaz razvoja koncepta razina u filozofskom smislu vidi Gnoli, 2017a, str. 41-43 i Gnoli, 2004b.
} 


\begin{tabular}{|c|c|c|}
\hline \multicolumn{3}{|c|}{ main classes: $\quad($ select + to expand $)$} \\
\hline a & forms & + \\
\hline b & spacetime & + \\
\hline c & branes & + \\
\hline d & energy & + \\
\hline e & atoms & + \\
\hline$f$ & molecules & + \\
\hline g & continuum bodies & + \\
\hline $\mathrm{h}$ & celestial bodies & + \\
\hline i & rocks & + \\
\hline j & land & + \\
\hline k & genes & + \\
\hline 1 & cells & + \\
\hline m & organisms & + \\
\hline n & populations & + \\
\hline$\circ$ & agency & + \\
\hline p & consciousness & + \\
\hline q & language & + \\
\hline $\mathbf{r}$ & customs & + \\
\hline s & communities & + \\
\hline$t$ & polities & + \\
\hline u & legal entities & + \\
\hline$v$ & enterprises & + \\
\hline w & artifacts & + \\
\hline$x$ & artworks & + \\
\hline$y$ & knowledge & + \\
\hline
\end{tabular}

Slika 3. Niz općih razina fenomena Klasifikacije integrativnih razina - razvojna verzija (ISKO, 2021)

Niz glavnih klasa klasifikacije integrativnih razina zamišljen po principu egzistencijalne ovisnosti klasa upućuje na važne klasifikatorske odluke o načinu reprezentacije svijeta. U svojem aktualnom stadiju Gnolijeva klasifikacija fenomena ne započinje klasama koje označuju materiju, već idealnim formama po uzoru na brojne druge klasifikacije koje žele postulirati postojanje formi tj. logičkih i matematičkih struktura, neovisno od ljudskog poimanja tih koncepata $(\# \mathrm{aWc})^{35}$ (ibid.). Uz forme glavne razine fenomena odnose se na

\footnotetext{
${ }^{35}$ Simbol “\#” koristi se za navođenje klasa fenomena, a simbol "W” označava neki raspon klasa fenomena.
} 
materiju (\#dWj), pojavu života (\#kWn), pojavu uma (\#oWp), društava (\#qWv) i kulturnog naslijeđa $(\# w W y)^{36}$.

Teorijsku osnovu za primjenu koncepta razina u klasifikaciji Gnoli pronalazi u filozofskim i znanstvenim tradicijama od antičke Grčke do modernih vremena. Najrelevantnija filozofska mišljenja predstavio je u tabeli (ispod) koja je ovdje prenesena u cijelosti pri čemu Gnoli (2017a), slično kao i Dahlberg, ističe značaj teorije o strukturi bitka Nicolaia Hartmanna. Značajna je i usporedba s filozofijom Karla Poppera čija je konceptualizacija „Svijeta 3“ dugo predstavljala relevantno filozofsko uporište za lociranje smještaja zabilježenog znanja tj. objektificiranog duha kao predmeta informacijskih i komunikacijskih znanosti definiranog u odnosu na druge razine stvarnosti koje predstavljaju interese drugih znanosti. Svijet 3 Gnoli poistovjećuje s konceptom kulturnog naslijeđa kojeg čine artefakti, umjetnine i zabilježeno znanje (već spomenuti mentefakti cf. Gnoli, 2018b; 2019) odnosno sve one razine u kojima se djelovanje intelekta bilježi u objektima izvan čovjeka samog.

Tabela 1. Glavne razine prema Klasifikaciji integrativnih razina u usporedbi $s$ prijedlozima glavnih razina nekih filozofa (Gnoli, 2017a)

\begin{tabular}{|c|c|c|c|c|c|}
\hline & Lloyd Morgan & RW Sellars & Hartmann & Poli & Popper \\
\hline form & & & ideal being & & \\
\hline matter & matter & inanimate & material & \multirow{2}{*}{ material } & \multirow{2}{*}{ world 1} \\
\hline life & life & animate & organic & & \\
\hline \multirow{2}{*}{ mind } & \multirow{4}{*}{ mind } & mind & psychic & \multirow{2}{*}{ psychological } & \multirow{2}{*}{ world 2} \\
\hline & & \multirow{3}{*}{ society } & \multirow{3}{*}{$\begin{array}{l}\text { personal spirit } \\
\text { objective spirit } \\
\text { objectivated spirit }\end{array}$} & & \\
\hline society & & & & \multirow{2}{*}{ social } & \\
\hline heritage & & & & & world 3 \\
\hline
\end{tabular}

Prednosti Klasifikacije integrativnih razina za interdisciplinarnu i transdisciplinarnu organizaciju znanja posebno su vidljive u načinu na koji se klasifikacija hvata ukoštac s problemom klasificiranja perspektiva. U tradicionalnom smislu klasifikacije su najčešće modelirale disciplinarne perspektive i to pomoću pristupa fasetne klasifikacije. Klasifikacija integrativnih razina definirana je kao slobodno fasetirana klasifikacija prema čemu bi se klase

\footnotetext{
${ }^{36}$ Kultura općenito označena je širim raspon od zajenica do znanja \#qWy.
} 
fenomena trebale moći slobodno kombinirati s obzirom na fasetnu logiku klasifikacije. Gnoli (2017b) fasete fenomena definira kao atribute fenomena koji specificiraju neko njegovo svojstvo ili odnos s drugim fenomenima. Fasete Klasifikacije integrativnih razina stvorene su sličnom logikom kakvu je primijenio Austin (1974) u kontekstu koncepta operatora uloge. Gnoli navodi da se u konstituciji faseta fenomena priklanja općoj teoriji sustava gdje se ,fenomeni tretiraju kao sustavi sačinjeni od nekoliko komponenata, ili dijelova, koji međusobno interreagiraju te tako čine integriranu cjelinu“ (Gnoli, 2017b, str. 3). Specifičnost je Gnolijeva (2017b) pristupa, a kongruentnog s mišljenjem Kleineberga (2014) iznesenog na početku ovog poglavlja, da smatra mogućim definirati opće kategorije i fasete fenomena neovisno o nekoj posebnoj domeni znanja. U Klasifikaciji integrativnih razina fasete su iskazane brojkama koje označavaju pojedinu kategoriju fasete, a za pojedine fasete definirani su i specijalni fokusi dezignirani alfabetskim notacijama (Gnoli, 2017b). Time fasete, kao općenitije kategorije, i na razini notacije prethode klasama u općem nizu Klasifikacije integrativnih razina (ibid.). Fasete se tretiraju kao preferirani način kombiniranja fenomena pri čemu je dopušteno kreativno kombiniranje pomoću bilo kojeg od indikatora kategorija (ibid.). Fenomeni se mogu i slobodnije klasificirati jednostavnim redanjem koncepata i njihovih odvajanjem razmakom gdje se ne specificira vrsta odnosa već opći odnos među klasama (ibid.). Iako je u Klasifikaciji integrativnih razina moguće kombinirati bilo koja dva fenomena, neke fasete imaju definirane fokuse (engl. extra defined foci) koji utvrđuju preferirane vrijednosti faseta i mjesto u klasifikaciji iz kojih se tipično biraju klase koje pobliže određuju tu fasetnu kategoriju (ibid.). Uz njih Gnoli je definirao i kontekstno definirane fokuse (engl. context defined foci) koji zadržavaju smisao samo ako se pridružuju posebno definiranom setu fenomena (ibid.).

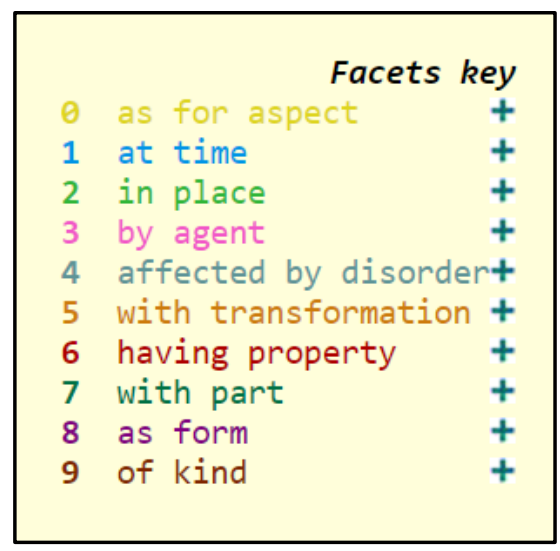

Slika 4. Kategorije faseta Klasifikacije integrativnih razina - razvojna verzija (ISKO, 2021) 
Gnoli ovu klasifikaciju tretira kao pravi jezik kojim se može izražavati bilo koji iskaz, a kako bi klasifikacija kao jezik bila cjelovita razvio je i specijalni set deiktičkih klasa kojima je moguće definirati konkretne instance fenomena koje postoje u stvarnome svijetu (ibid.).

Kategorije faseta mogu se odnositi na različite kvalitete fenomena; njegov oblik, količinu ili konzistenciju; dijelove koji ga čine ili ga dezigniraju kao dio drugog fenomena; različite atribute, razvojne stadije; procese, stanja transformacije ili disrupcije u kojima se fenomen može nalaziti; komunikacijske funkcije koji ga terminološki pozicioniraju spram drugih fenomena; različita određenja aktora koji djeluju na fenomen, koji ga produciraju ili koriste; kontekste, miljee i mjesta u kojima se fenomen može nalaziti; vrijeme u kojem se zbiva ili na koje se odnosi; kao i gledište s kojeg je razmatran. Više o perspektivama bit će razrađeno u idućem poglavlju.

Posljednji element Klasifikacije integrativnih razina ne odnosi se na strukturu klasifikacije već na način njena korištenja. Naime, Gnoli je razvio pravila za sklapanje tema i rema tj. kompleksnih klasifikacijskih oznaka koje ih izražavaju. Teme je moguće reprezentirati sukcesivnim navođenjem fenomena pri čemu svaki fenomen može biti pridružen i nekim fasetnim kategorijama (Gnoli, 2018a). Reme se izražavaju pomoću velikog početnog slova (ibid.). Teme Gnoli definira kao dijelove predmeta nekog dokumenta koji stoje u nekim odnosima što znači da se pretpostavlja da dokument može imati više od jedne teme (ibid.). Reme definira kao nove informacije o pojedinoj temi dokumenta (ibid.). Prvo se navode one teme koje je indekser odredio kao glavne, a njega slijede sekundarne teme i deiktičkim klasama specificirane reme (ibid.). Uvođenjem tema i rema u klasifikaciju fenomena Gnoli se želi približiti postojećim konceptualnim modelima definiranja sadržaja dokumenata kao što je to IFLA-in FRBR model pri čemu je tema u Klasifikaciji integrativnih razina podudarna $\mathrm{s}$ themom tog modela, notacija s nomenom, dok res označava same fenomene na koje se tema odnosi (ibid.). Gnoli i sam zamjećuje da postojeće konceptualizacije bibliografskog univerzuma ne modeliraju razlike među temama (ibid.), no toj se primjedbi mora još dodati i to da oni ne modeliraju ni odnos tema i perspektiva, posebice ako uzmemo u obzir da se koncepti i objekti koje se doživljava kao kategorije autoritativnih podataka mogu kvalificirati drugim temama, ali i svim drugim atributima tema. 


\section{Jamstvo perspektive u interdisciplinarnom i transdisciplinarnom kontekstu}

Izgled područja organizacije znanja i projekti koji u njemu nastaju rezultat su trajnog osluškivanja informacijskih potreba u svim društvenim kontekstima u kojima je djelatnost organizacije znanja relevantna i potrebita. Dominantna reorijentacija, a čak bi vrijedilo reći i promjena paradigme, iz domenski usmjerenih pristupa na pristupe koji modeliraju odnose između većeg broja domena znanja nije tek odraz neke unutarnje dinamike područja organizacije znanja. Opisane promjene u području odraz su promjena u globalnom informacijskom kontekstu koji postaje saturiran problemima visoke kompleksnosti (npr. globalno zatopljenje, pandemija koronavirusa, glad, zaštita osobnih podataka, istraživanje svemira itsl.) čije razrješenje ne može biti prepušteno niti ostvareno u okvirima pojedinačnih, međusobno izoliranih znanosti ili pak voljom odabranih pojedinaca ili posebnih društvenopolitičkih interesnih zajednica. Prema Szostaku i suradnicima (2016), interdisciplinarnost postaje nužna i tražena jer se rješenja specijaliziranih eksperata za kompleksne probleme društva prepoznaje kao nedostatne. U znanosti se interdisciplinarnost može pratiti već desetljećima, ali se njena narav mijenja jer interes više ne leži u pronalasku neke velike unificirajuće teorije već u integraciji različitih teorija koje u okviru vlastitih disciplinarnih tradicija analiziraju i nude odgovore vezane za neke specifične aspekte koji se dijelom međusobno preklapaju (ibid.). Pretpostavka je dakle, da je integrirano znanje koje proizlazi iz suradnje više različitih disciplina ključni smjer razvoja suvremene znanosti. Ne treba zaboraviti niti argument koji je ponudila Dahlberg o porastu aspektnog pristupa istraživanju pojedinih fenomena što također može dovesti do suradnji među disciplinama. Volju da se znanstvenici različitih disciplina sve više udružuju mogao bi stimulirati i rastući broj prilika za financiranje interdisciplinarnih istraživanja koja su zasigurno stekla status popularnosti, a Szostak i suradnici (2016) navode i ekonomske razloge, poput financijskih uvjeta sveučilišta koja smanjuju broj zaposlenih, kao mogući razlog porasta interdisciplinarnih suradnji.

Za knjižnične i informacijske znanosti opisani kontekst oblikuje vrlo jasne i specifične zadaće, a koje se prvenstveno odnose na osmišljavanje raznolikih vrsta podrške i razrješenja inter- i transdisciplinarnih informacijskih potreba. Informacijske potrebe istraživača koji provode interdisciplinarna istraživanja vrlo su slična tj. umnogome jednaka potrebama istraživača i tražitelja informacija u transdisciplinarnome kontekstu (ibid.). Potrebe istraživača koji provode interdisciplinarna istraživanja jesu prema Szostaku i suradnicima (ibid., str. 36) sljedeće: 
1. “...htjet će znati što je bilo rečeno od strane drugih znanstvenika (dapače, i onih koji se nalaze izvan sveučilišta) o pojedinačnim fenomenima (odnosno o stvarima $i$ varijablama koje proučavamo), a posebice o odnosima koji bi mogli postojati između dvaju ili više fenomena."

2. “...htjet će znati koje teorije su bile primijenjene nad fenomenima i odnosima koji ih interesiraju."

3. “...htjet će znati koji dokazi podupiru različite teorije, a to znači da će htjeti znati koje metode su bile primijenjene nad fenomenima i odnosima koji ih interesiraju kao i koji podaci su bili prikupljeni u njihovom razmatranju."

4. “...trebat će razumjeti značenja koja pripadaju pojedinim terminima."

5. “...s obzirom na to da općenito razumiju da svaka disciplina ima vlastitu disciplinarnu perspektivu, htjet će vrednovati disciplinarne uvide u kontekstu tih disciplinarnih perspektiva. Također, htjet će općenito znati o disciplinarnim afilijacijama i gledištu autora, kao i imati pristup djelima koje opisuju discipline. [Na isti način trebat će slične informacije o interdisciplinarnosti samoj]."

6. bit će im potreban sintetički pristup klasifikaciji jer autori smatraju da će se tako lakše omogućiti klasifikacija različitih odnosa.

7. s obzirom na to da "disciplinarne perspektive obuhvaćaju niz filozofskih stajališta [...] htjet će razmatrati djela klasificirana prema raznim perspektivama feminizam, postmodernizam, i tako dalje - koje autori donose u djela."

Uz ove potrebe Szostak i suradnici (2016) navode i druge potrebne informacije, kao što su vrijeme i mjesto nastanka dokumenata. Nadalje, isti autori spominju i pet tipova općih informacijskih potreba prema Davisu i Shawu (2011, str. 31-32 kod ibid.): proceduralne (tj. biti upoznat s teorijama i metodama), supstantivne (tj. biti upoznat s postojećim sadržajima o fenomenima i njihovim odnosima), verifikativne ( $\mathrm{tj}$. biti upoznat $\mathrm{s}$ argumentima koji su nastali u drugim disciplinama kao i dostupnim dokazima koji podupiru pojedine argumente), obrazovne (tj. potrebe koje se odnose na vještinu prepoznavanja praznina u znanju i mogućnost definiranja novih informacijskih problema na temelju dosadašnjih saznanja) te potrebu za informacijama koje će istraživaču omogućiti da utvrdi kakvu vrstu informacija uopće može tražiti ili očekivati u drugim područjima. Upravo na razini posljednje dvije vrste potreba Szostak i suradnici ističu kako je najčešći izvor nerazumijevanja nejasna i strana terminologija drugih područja, no da upravo klasifikacija može reducirati ambigvitet koji proizlazi iz različitosti korištenih terminologija. Jednom kada se razriješi pitanje terminologije 
klasificiranje djela prema teorijskoj, metodološkoj ili disciplinarnoj perspektivi pomoći će istraživačima da dođu do relevantnih informacijskih izvora, a već je pojašnjeno da mnogi autori u području organizacije znanja smatraju da je podrška takvih interdisciplinarnih informacijskih potreba najlakše ostvariva izgradnjom univerzalne klasifikacije fenomena.

Za mnoga od dosad prikazanih razmatranja u području klasifikacije karakteristična je evokacija koncepta perspektive bilo da je riječ o zastupljenosti disciplinarnih ili podzastupljenosti nedisciplinarnih perspektiva (Leon Manifesto, 2007; Gnoli, 2008a; Cameron i Mengler, 2009; García Gutiérrez, 2011; Kaipainen i Hautamäki, 2011; Gnoli, 2012; Lopez-Huertas, 2013; García Gutiérrez, 2014; Kleineberg, 2014; Lopez-Huertas, 2015; Szostak, Gnoli i Lopez-Huertas, 2016). Prethodno izneseni povijesni prikaz, od samih začetaka klasifikacije pa do suvremenih sustava za organizaciju znanja poput klasifikacija fenomena, imao je svrhu objasniti temeljne teorijske koncepte, disciplinarne dileme i izazove područja organizacije znanja kao i neke strukturalne elemente sustava za organizaciju znanja, a oni čine preduvjete za podršku informacijskih potreba interdisciplinarne znanosti, osiguranje jamstva perspektive i umanjenje ograničenja disciplinarnih klasifikacija. Kako bi povijesni pregled bio zaokružen potrebno je objasniti izvorište ideje jamstva perspektiva koja proizlazi iz jednog od temeljnih teorijskih i metodoloških principa područja organizacije znanja tj. samog koncepta jamstva. Koncept jamstva prvi se puta pojavio 1911. godine u djelu Wyndhama Hulmea Principi klasifikacije knjiga i to u okviru koncepta literarnog jamstva (Barité, 2018). Literarno jamstvo osiguravalo je da će se sadržajno označavati samo ona građa koja zaista postoji i da će postojeća literatura uvijek činiti osnovicu sustava za organizaciju znanja (ibid.). Osnova za klasifikaciju prema tome uvijek bi trebao biti neki set stvarno objavljene literature (ibid.). Takav je pristup klasifikaciji višestruko kritiziran i modificiran (ibid.), no samo literarno jamstvo zadržalo se kao relevantan opći metodološki princip sve do danas. Jamstvo predstavlja pozadinske pretpostavke i semantička opravdanja za ustroj nekog sustava koje će kreator sustava koristiti kao polazišnu točku i izvorište autoriteta za donošenje odluka (i njihovu provjeru) o tome kakva će biti struktura sustava, koji će se koncepti ili klase u njemu moći okupljati, kako će se sustav koristiti za sadržajno označivanje i dr. (Beghtol, 1986b). Barité (2018) objašnjava kako se ideja jamstva počela povezivati i s drugim aspektima sustava za organizaciju znanja kako bi se osigurale neke njegove kvalitete npr. korisničko jamstvo, kulturno, obrazovno, akademsko, organizacijsko, etičko, epistemičko, rodno i dr. vrste jamstava (ibid.). 
Krajem 20. stoljeća, u razdoblju kada je većina univerzalističkih projekata napuštena, 1998. godine pojavljuje se rijedak članak autorice Claire Beghtol o općim klasifikacijskim shemama s namjerom pojašnjenja potreba organizacije znanja koje proizlaze iz multidisciplinarnih suradnji. Da bi sustavi za organizaciju znanja mogli primjereno odražavati različite perspektive surađujućih disciplina Beghtol je prepoznala potrebu za takozvanim jamstvom perspektive (engl. viewpoint warrant) (Gnoli, 2008a). Njen je zahtjev već tada tražio organizaciju znanja koja ne bi bila temeljena na akademskim disciplinama, a jamstvo perspektive vidjela je kao alat beskonačne hospitalnosti koji bi potencijalno mogao prikazati sve vrste perspektiva (Beghtol, 1998).

Zahtjev za reorijentacijom područja prema interdisciplinarnoj organizaciji znanja zabilježen je 2007. godine u obliku dokumenta koji je upamćen kao Leonski manifest. Ovdje donosimo prijevod tog dokumenta u cijelosti jer je riječ o kratkom dokumentu izrazitog značaja za područje organizacije znanja:

„Prijedloge označene ovdje kao Leonski manifest moguće je sažeti u nekoliko sljedećih točaka:

- trenutni trend povećanja interdisciplinarnosti znanja zahtijeva razvoj novih sustava za organizaciju znanja koji će se temeljiti na temeljitoj reviziji principa tradicionalnih disciplinarnih sustava za organizaciju znanja;

- inovacija nije samo poželjna, već i ostvariva te bi trebala biti implementirana tako da se zaista razviju neki novi sustavi za organizaciju znanja;

- umjesto disciplina, temeljne jedinice novih sustava za organizaciju znanja trebali bi biti fenomeni stvarnog svijeta onako kako je prikazan u zabilježenom ljudskom znanju;

- novi sustavi za organizaciju znanja moraju omogućiti korisnicima da se prebacuju iz jedne perspektive ili gledišta na druge, tako reflektirajući multidimenzionalnu strukturu i kompleksnost mišljenja. Posebice bi im trebali omogućiti neovisno pretraživanje pojedinih fenomena, pojedinih teorija o fenomenima ( $i$ o odnosima među fenomenima), kao i pojedinih istraživačkih metoda;

- spojevi među fenomenima, oni između fenomena i teorija koje ih proučavaju te oni između fenomena $i$ istraživačkih metoda mogu biti izraženi analitičko-sintetičkim tehnikama koje su već razvijene u fasetnoj klasifikaciji.“ (ISKO - Leon Manifesto, 2007). 
U recentnim razmatranjima Claudio Gnoli jamstvo perspektive definira upravo na temelju Manifesta kroz perspektivu korisnika kojima „bi trebalo biti omogućeno da se prebacuju između različitih gledišta [u nekome sustavu za organizaciju znanja], kako bi mogli odabrati onu koju preferiraju, ali $i$ istražiti kako se povezano znanje može iskazati iz različitih perspektiva“ (Gnoli, 2008a, str. 142). Pozivajući se na teoriju analize domene Gnoli (2011, str. 91 prema Hjørland i Hartel, 2003) objašnjava da: „sustavi za organizaciju znanja nisu samo iskaz strukture stvarnog svijeta (ontološka dimenzija) i naše sposobnosti da je percipiramo (epistemološka dimenzija) već i odraz kulturnog miljea i pragmatičkih svrha koje određuju kontekst u kojem se razvijaju (sociološka dimenzija). Ta sociološka dimenzija pred jamstvo perspektive postavlja zahtjev da sustavi za organizaciju znanja odražavaju postojanje koncepata i njihovih međuodnosa s obzirom na stvarnu kulturu u kojoj su nastali“. Na temelju rada Claire Beghtol, Gnoli naglašava da takvo shvaćanje konstituira i etički princip tj. da , $u$ globalnom informacijskom kontekstu organizacija znanja ne bi trebala privilegirati niti jednu kulturu, već omogućiti da je reprezentirana perspektiva svakoga“ (Gnoli, 2011, str. 94) ${ }^{37}$.

Ovdje je važno napraviti digresiju i napomenuti da i Univerzalna decimalna klasifikacija, kao najrasprostranjeniji disciplinarno orijentirani sustav za organizaciju znanja, također poznaje ideju klasificiranja djela prema perspektivama. U komentaru priloženom uz 19. izdanje Dopuna i izmjena Univerzalne decimalne klasifikacije iz 1997. godine Geoffrey Robinson (British Standards Institution) objašnjava povijest uvrštavanja ideje klasificiranja prema perspektivama u UDK. Taj komentar posebno je zanimljiv jer nastaje u trenutku pripreme ukidanja Pomoćne tablice za gledište. Robinson pojašnjava kako: “opis gledišta u aspektnoj klasifikaciji nema smisla jer svi unosi izražavaju točku gledišta neke vrste; štoviše svaka pomoćna tablica izražava pojedinu fasetu (tj. rezultat dane karakteristike podjele), koje bismo podjednako dobro mogli nazvati 'gledištem ili perspektivom'. Tabelu ld za 'gledište s obzirom na oblik', Tabelu le za 'gledište s obzirom na mjesto' i tako dalje." (Robinson, 1997, str. 29). Nadalje upućuje i na sama izvorišta UDK te navodi kako je i sam naziv sporne Pomoćne tablice za gledište prevoditeljskom greškom poprimio trenutni oblik. Referirajući se na francuski izvorni naziv iz 1907. godine koji je glasio Table des subdivisions des points de vue généraux (Subdivision analytique commune) smatra da utemeljitelji UDK, Otlet i La

\footnotetext{
${ }^{37}$ Ovdje se Gnoli referira i na koncept kulturnog jamstva koji implicira da je svaki klasifikacijski sustav nužno osmišljen iz perspektive neke kulture te da će sustav time biti korisniji pripadnicima te kulture nauštrb drugih (cf. Beghtol, 2002b). Prema Beghtol (2002b) opisani problem osnova je za uvođenje posebnog teorijskog principa kulturne hospitalnosti koji se ostvaruje kao zahtjev da sustavi za organizaciju znanja budu temeljeni na univerzalnim konceptima. Isti princip inspirirao je Claudija Gnolija da osmisli sustav slobodnijih struktura koji će moći djelovati kao internacionalno sveobuhvatni sustav za organizaciju znanja.
} 
Fontaine, nisu do kraja bili zadovoljni ovim nazivom. To se pokazalo točnim jer je 1933. godine naziv te tablice postao mnogo precizniji i tada glasio Subdivisions de points de vue généraux de caractère théorique, technique et social. Robinson (1997) konačno razotkriva da u kasnijem prijevodu na njemački jezik 1934. godine prevoditelj nije preveo posljednjih šest riječi pa od toga trenutka u uporabi ostaje pokraćeni naziv Pomoćna tablica za gledište. Prema Robinsonu (1997) ova je tablica proizvodila višestruke probleme. U svojoj analizi zamjećuje da je opis opsega tablice vrlo nedorečen i široko postavljen pa smatra da bi se u nju moglo staviti i bilo što. Opis je izvorno glasio ovako: "SCOPE. The point-of-view auxiliaries denote the most general points of view from which a subject may be considered: concept, theory, function, activity, processes etc...” (ibid., str. 29). Dakle, tablice se odnose na opća gledišta prema kojima se neki predmet može razmatrati bilo da je riječ o konceptu, teoriji, funkciji, aktivnosti, procesima itd. Autor napominje kako opseg tablice nije bio jasnije izražen ni 1970. godine kada je tablica doživjela značajniju reviziju. Njegova sljedeća zamjedba spram konstrukcije ovih tablica ukazuje na to da se mnogi koncepti ili mogu lako uključiti u druge pomoćne tablice ili pak da su koncepti istoga opsega već uključeni u UDK na drugim mjestima. Konačno, navodi i probleme s notacijom te prednosti uporabe simbola dvotočke za konstrukciju složenih brojeva opsegom jednakih konceptima Pomoćne tablice za gledište. Tablica je konačno isključena iz UDK jer se smatralo da je revizija uspjela sva gledišta adekvatno reprezentirati u drugim dijelovima klasifikacije te bi se s obzirom na to moglo argumentirati da UDK zapravo ne primjenjuje jamstvo perspektive u punom ekstenzitetu i intenzitetu koji omogućuje fasetna klasifikacija.

Fokus Leonskog manifesta na fenomene bio je vjetar u leđa novim klasifikacijskim projektima poput onog Ricka Szostaka i Claudija Gnolija, a zagovor perspektiva, i to posebice teorijskih i metodoloških perspektiva, potaknut će ih da pokušaju razviti sistematične načine klasificiranja teorija i metoda.

Szostak (2007) će najprije govoriti o klasifikaciji prema teorijama i metodama, a kasnije o autorskim perspektivama gdje će kao tipove tih perspektiva navoditi discipline, metode, teorijske orijentacije, ideološke, epistemološke, etičke i estetičke nazore te poduzete retoričke strategije. Szostak (2007) smatra da bi oznake za fenomene, teorije i metode trebale stajati odvojene razmakom kao zasebne teme dokumenta kako bi dokumenti bili pretraživi prema teorijama i metodama i neovisno od fenomena kojemu su pridruženi. Određenje teorija i metodoloških pristupa vidi kao rezultat uske suradnje stručnjaka koji se bave pojedinim 
fenomenima i informacijskih znanstvenika koji kombiniraju deduktivne $\mathrm{i}$ induktivne pristupe (ibid.). Szostak (2007, str. 473) nudi listu vrsta metodoloških pristupa koju smatra iscrpnom: „klasifikacija sama, eksperimenti, intervjui, ankete, opažanje, statistička analiza, matematičko modeliranje, analiza teksta, tvorenje mapa $i$ hermeneutika/semiotika (studije simbola)“. Klasifikaciju teorija vidi kao problematičan aspekt klasifikacije perspektiva jer potencijalno postoji beskonačan broj teorija te se nove stalno generiraju (ibid.). Ističe i daljnji problem da su nazivi teorija često polisemni jer neki nazivi upućuju na različite teorijske argumente, dok se teorije koje nude srodnu argumentaciju često različito imenuju (Szostak, 2007; Szostak i Gnoli, 2008). Kao rješenje nudi da se teorije klasificira prema vrsti teorije tj. prema nekim ključnim pitanjima koje ih međusobno razlikuju kao što su primjerice određenja djelatnih faktora na koji se teorije odnose (namjerna i nenamjerna djelatnost nekih agensa), vrste aktivnosti koje ti agensi poduzimaju (pasivno, aktivno, promjena ponašanja), razlozi poduzimanja aktivnosti, temporalna određenja kauzalnog procesa ili stupanj njegove poopćivosti (Szostak et al., 2016). Nešto kasnije Szostak i Gnoli (2008) pokušat će razviti tipologiju teorije na temelju literarnog jamstva u društvenim znanostima i jedinstveno ih označiti notacijom Klasifikacije integrativnih razina jer uviđaju da prethodno opisana tipologija može rezultirati smještajem iste teorije u više različitih skupina (ibid.). Razvijaju četrdesetak tipova teorija društvenih znanosti, no zaključuju da iako teorije nije problematično odrediti notacijski same teorije su često vrlo nejasne ili ih različiti teoretičari različito tumače (ibid.). Svoj osvrt o teorijama društvenih znanosti završavaju poticajem da je potrebno zajedničkim snagama autora i klasifikatora odrediti i kategorizirati vrste teorije te naglašavaju mogućnost korištenja drugih dimenzija za njihovu kategorizaciju prema lokalnom gledištu, epohama, ljudskoj aktivnosti ili čak ponovo u relaciji prema disciplinama (ibid.).

Razmatranje teorijskih i metodoloških perspektiva u konačnici Szostak uključuje u širi model autorskih perspektiva (Szostak, 2015). Autorske perspektive definira kao namjere autora ili određenja njegovih pogleda niz nekoliko dimenzija prikazanih i specificiranih u tabeli ispod (ibid.). Kao prednosti klasificiranje prema autorskoj perspektivi vidi razotkrivanje relevantnih djela, olakšanu komunikaciju unutar i između društvenih grupa, ali i razotkrivanje pristranosti autora ili situacija u kojima autori namjerno obmanjuju čitatelja (ibid.). Smatra da će klasifikacija autorskih perspektiva biti znatno olakšana ako je ugniježđena u neki opći klasifikacijski sustav (ibid.). Autorske perspektive za njega čine discipline kao disciplinarni dom autora; metode koje primjenjuje, a koje bi se u odnosu na prethodno spomenuti popis metoda moglo dodatno specificirani podvrstama i karakteristikama pojedinih vrsta (npr. poput 
broj ispitanika u intervjuima); teorijska orijentacija prema već pojašnjenim pitanjima i vrstama teorija; ideološki pogled (,klasični liberalizam, libertarijanizam, pragmatički liberalizam, konzervativizam, socijalizam, komunizam, fašizam, anarhizam i nacionalizam “ (ibid., str. 64); etički pogled; epistemološki pogled; estetički pogled; retoričke strategije i razina obrazovanja autora (ibid.).

Tabla 2. Klasifikacija autorskih perspektiva (Szostak, 2015)

\begin{tabular}{|c|c|c|}
\hline Main Dimensions & Subsidiary Dimensions & Possibilities along Dimensions \\
\hline Discipline & & Disciplines and Fields \\
\hline Methods & & $\begin{array}{l}12 \text { main types, particular } \\
\text { techniques }\end{array}$ \\
\hline $\begin{array}{l}\text { Theories } \\
\text { [Note need to classify by } \\
\text { both theory name and } \\
\text { theory type. The latter } \\
\text { can be classified along } \\
\text { five dimensions.] }\end{array}$ & $\begin{array}{l}\text { Who is the agent? } \\
\text { What does the agent do? } \\
\text { Why does the agent do this? } \\
\text { Where does the process occur? } \\
\text { When does the process occur? }\end{array}$ & $\begin{array}{l}\text { Intentional/non; individual, group, } \\
\text { relationship } \\
\text { Act, react, form attitude } \\
\text { Innate nature if non-intensional; } 5 \\
\text { types of decision-making if } \\
\text { intensional } \\
\text { Continuum of generalizability } \\
\text { Equilibrium, cycle, change in one } \\
\text { direction, stochastic }\end{array}$ \\
\hline Ideology & & $\begin{array}{l}\text { Several distinct ideologies; also } \\
\text { issue-specific attitudes }\end{array}$ \\
\hline Ethics & $\begin{array}{l}\text { Consequentialist } \\
\text { Deontological } \\
\text { Virtue/value } \\
\text { Tradition } \\
\text { Intuition } \\
\end{array}$ & $\begin{array}{l}\text { By desired consequence } \\
\text { Golden Rule, or particular rights } \\
\text { Particular values } \\
\text { Particular groups or general } \\
\text { Emotions, personality dimensions }\end{array}$ \\
\hline Epistemology & $\begin{array}{c}\text { Motivation } \\
\text { Methodology } \\
\text { Confirmation } \\
\text { Objectivity/Subjectivity } \\
\text { Realism }\end{array}$ & $\begin{array}{l}\text { Basic versus applied; advocate } \\
\text { particular outcomes } \\
\text { Deductive/Inductive?; Mixed? } \\
\text { Replication?; Data? } \\
\text { Continuum } \\
\text { Realism, constructivism; maybe } \\
\text { optimism, pessimism }\end{array}$ \\
\hline Aesthetics & & What is beautiful? \\
\hline Rhetoric & $\begin{array}{c}\text { Ethos } \\
\text { Pathos } \\
\text { Particular strategies }\end{array}$ & $\begin{array}{l}\text { Analyze cause/effect; define; } \\
\text { compare/contrast; classify; } \\
\text { describe person/place/thing; } \\
\text { explain how something happens; } \\
\text { narrate a story } \\
\text { Occupation, education, etc. } \\
\text { Link to emotions } \\
\text { A dozen or so }\end{array}$ \\
\hline Target knowledge level & & $\begin{array}{l}\text { Education level assumed, by field } \\
\text { if necessary }\end{array}$ \\
\hline
\end{tabular}


Gnoli definira nekoliko faseta perspektiva koje je implementirao i u Klasifikaciju integrativnih razina, a to su komunikativna funkcija, disciplina, domena diskursa, kulturni kontekst, područje djelovanja, teorija, metoda, mjesto i vrijeme (Gnoli, 2016), no uzima u obzir i sve do sada iznesene prijedloge. Već je pojašnjeno da je u Klasifikaciji integrativnih razina predviđeno fasetno tretiranje kategorija perspektiva. Pri tome je važno napomenuti da se na svaki fenomen gleda kao na sustav kojemu se pridružuju različite kvalifikacije ili uloge koje obnaša (ibid.).

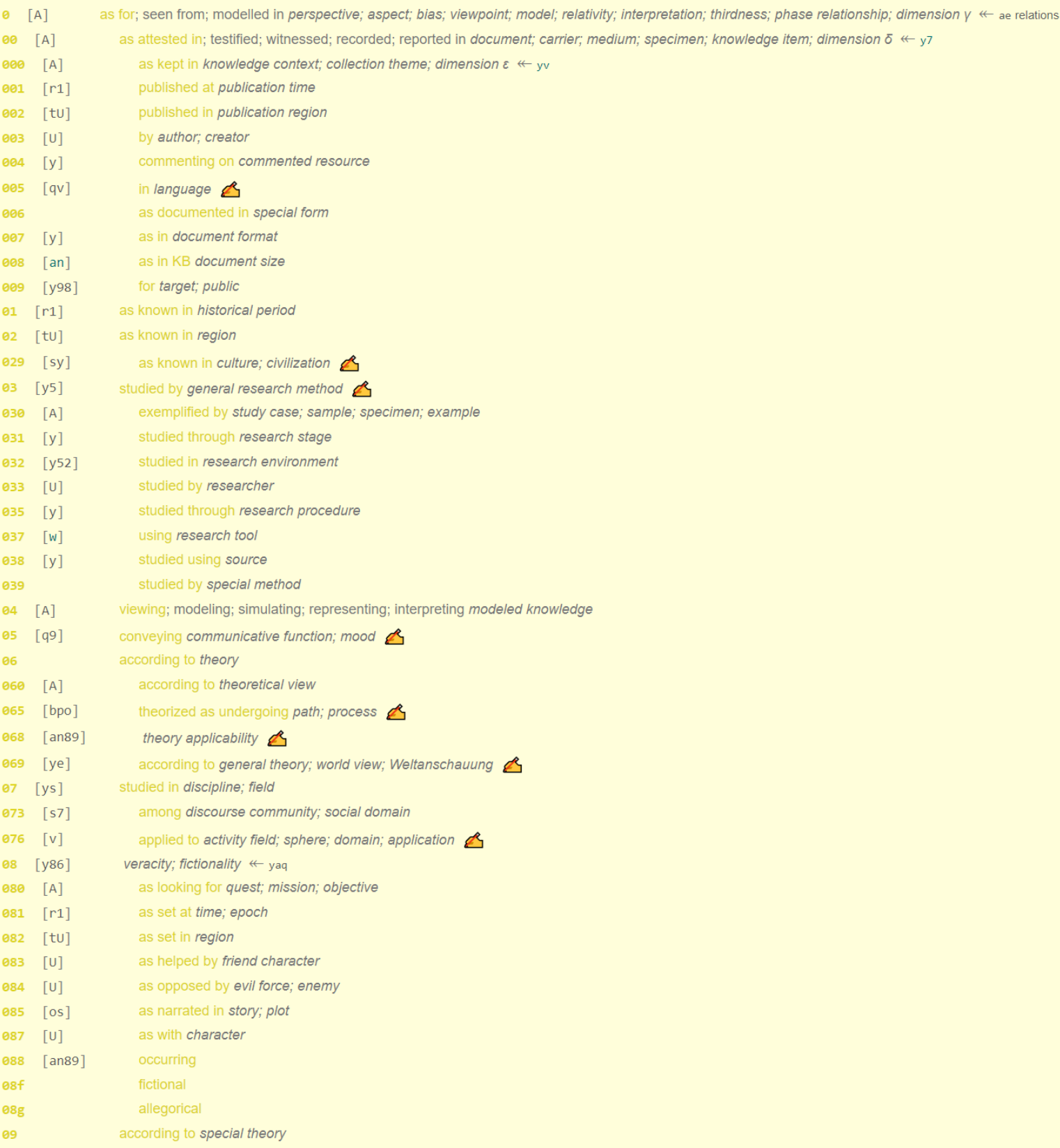

Slika 5. Hijerarhija faseta za osiguranje jamstva perspektive u Klasifikaciji integrativnih razina - razvojna verzija (ISKO, 2021) 
Iako je svaka od devet razina faseta detaljno razrađena, na razini rasprave o autorskim perspektivama najrelevantnija je kategorija 0 koja se odnosi na perspektive u najopćenitijem smislu (vidi sliku iznad). Temeljne kategorije koje modelira jesu specifikacija medija u kojem se raspravlja o nekom fenomenu, povijesni period ili geografsku regiju na koji se odnosi; vrstu metodološkog pristupa kojim je razmatran, način na koji je modeliran, komunikativnu funkciju koju zauzima, teorijski pristup kojim je određen i disciplinu koja ga može proučavati. Mnoge od navedenih kategorija imaju i potkategorije koje dodatno specificiraju moguće odnose između fenomena kao što su npr. određenja fenomena u odnosu na neki kulturni kontekst, diskurzivnu zajednicu koja ga smatra predmetom vlastitog interesa, domenu djelatnosti za koju je relevantan i dr.

Najrecentnije pokušaje sistematskog razmatranja teorija i metodologija pronalazimo $u$ radu Michaela Kleineberga koji razvija dva pristupa njihovoj klasifikaciji. Riječ je o pristupima od kojih je prvi inspiriran radom Piageta i Inheldera na integrativnim razinama spoznavanja (Kleineberg, 2016) te drugi inspiriran Wilberovim integralnim metodološkim pluralizmom (Kleineberg, 2014). Kleineberg (2016) poistovjećuje klasificiranje perspektiva s klasificiranjem prema epistemičkom kontekstu autora dokumenata polazeći od ideje epistemičkog pluralizma prema kojoj neutralnost spoznajnih tvrdnji nije moguća jer je njihov tvorac uronjen u društveni i kulturni kontekst (ibid.). Primijetivši da organizacija znanja još uvijek nema dobro rješenje za ne-relativističku organizaciju tog pluralizma pokušao je razraditi hijerarhiju integrativnih razina spoznavanja koja bi jedinstveno obuhvatila doprinose različitih mislioca ontogenetičkom i historiogenetičkom određenju razvoja ljudske kognicije i svijesti (ibid.). U kontekstu klasifikacije metodologija Kleinebergova je intencija bila ponuditi „meta-okvir kvalitativno različitih vrsta znanja“ s obzirom na metodologije kojima ih se producira (Kleineberg, 2014, str. 133). Ponuđene klasifikacije još uvijek nisu implementirane u neki sustav za organizaciju znanja, no Kleineberg je u svojoj recentnoj disertaciji ponudio način njihove implementacije u Klasifikaciju integrativnih razina.

Szostak i suradnici (2016) u okviru vlastitog pristupa interdisciplinarnoj organizaciji znanja koja je, prema njima, primjerena i za potrebe transdisciplinarnih istraživanja navode kako bi sljedeći istraživački pothvati trebali ponajprije istražiti postojeću razinu kompleksnosti u definiciji fenomena i njihovih dimenzija te zahtjeve korisnika. Taj prijedlog istraživanja postojeće razine kompleksnosti odnosi se na razotkrivanje fenomena koji se pojavljuju u pojedinim područjima zabilježenog ljudskog znanja i dimenzija koje ih karakteriziraju i 
sudjeluju u njihovoj sveobuhvatnoj definiciji. Slično, na kraju svoje analize strukturalnih elemenata Klasifikacije integrativnih razina Gnoli ističe da bi sljedeći potrebni koraci u razvoju sustava trebali biti testovi njegovih granica tj. primjena sustava na stvarne kontekste indeksiranja kako bi se uspostavljeni principi testirali u praksi (Gnoli, 2018). 


\section{Integrativna bioetika i trenutni dosezi osiguranja predmetnog pristupa u bioetici}

Gnolijeva i Szostakova vizija budućnosti razvoja područja klasifikacije fenomena značajna je za definiciju znanstvenog rada u okviru revitalizirane univerzalističke paradigme organizacije znanja. Njihova je vizija poziv znanstvenicima i stručnjacima da lociraju i istražuju domene znanja intrigirajuće kompleksnosti.

Kao što je rečeno u uvodnome poglavlju, motivacija za bavljenje temom osiguranja jamstva perspektive $\mathrm{u}$ interdisciplinarnoj i transdisciplinarnoj organizaciji znanja proizlazi iz stvarnog poslovnog konteksta kandidata i potrebe znanstvenika i stručnjaka u području integrativne bioetike da mogu identificirati i pronaći znanje zabilježeno u dokumentima s obzirom na perspektivu prema kojoj se predmeti nekog djela razmatraju. Djela za koja je iskazana potreba pristupa takve vrste nalaze se u zbirkama raznovrsnih akademskih i neakademskih dokumenata znanstvenih i stručnih institucija u području bioetike, i specifično, integrativne bioetike.

Dovoljan poticaj za razmatranje načina organizacije znanja u području etike moglo bi općenito biti i već uvriježeno laičko mišljenje da je ono jedno od područja iznimnog stupnja ambigviteta. No, u ovom poglavlju bit će objašnjene temeljne informacije o bioetici kao području, a onda i o specifičnoj konceptualizaciji integrativne bioetike koja područje bioetike redefinira kao područje izrazitog interdisciplinarnog i transdisciplinarnog karaktera, a time i od značajnog interesa za područje organizacije znanja.

Kao trenutak u povijesti kojem se pripisuje nastanak bioetike obično se uzima 1962. godina kada se u Sjedinjenim Američkim Državama osniva prvi etički komitet (Zagorac, Jurić, 2008). Njegovo osnivanje obilježeno je teškim etičkim dilemama o očuvanju života odabranih pojedinaca u uvjetima ograničenih mogućnosti i resursa (ibid.). Naime, spomenuti tzv. "Božji komitet" trebao je odlučiti kome će od potrebitih bolesnika biti omogućen pristup liječenju pomoću, tada inovativnog, stroja za dijalizu bubrega koji nije mogao postati dovoljno brzo dostupan svim bolesnicima (ibid.). Zanimljivost je toga komiteta da njegov sastav nisu činili samo liječnici, već i ljudi iz drugih sfera društva. Prema Zagorac i Jurić (ibid., str. 602) dolazi do uvođenja "nove vrste refleksije" i "nove medicinske etike, kasnije bioetike, nasuprot tradicionalne hipokratske medicinske etike". Sam se termin prvotno pripisivao Van Rensselaeru Potteru (ibid.), a kasnije i Fritzu Jahru kao preteči suvremene bioetike (Kos, 2014). Van Rensselaer Potterov pristup bioetici, poznatiji pod nazivom globalna bioetika, 
sukobio se s antropocentričnim i individualističkim orijentacijama medicinske etike te proširio horizont bioetike na preživljavanje vrsta (ljudskih i ne-ljudskih živih bića) i ekosustav planete u cjelini u kontekstu moralnih dilema koje proizvodi znanstveno-tehnički napredak (Zagorac, Jurić, 2008). Prema Zagorac i Jurić (ibid., str. 603) ,pomak se zbiva i na metodološkom planu, gdje je bioetika nadrasla neposrednu moralnu refleksiju, svojstvenu prvome razdoblju u razvoju bioetike, te se uzdigla do razine etičke refleksije“.

Za kontekst Republike Hrvatske relevantno je spomenuti da se ubrzanje razvoja bioetike devedesetih godina 20. st. pripisuje, s jedne strane djelovanju Ivana Šegote i Katedre društvenih znanosti Medicinskog fakulteta Sveučilišta u Rijeci čiji je doprinos ponajprije bio u razvoju i širenju bioetičke edukacije, a s druge strane razvoj područja može se pripisati i organizaciji znanstvenih skupova specifično usmjerenih na bioetičke teme u sklopu manifestacija poput Dana Frane Petrića i kasnije Lošinjskih dana bioetike. Za prvu navedenu manifestaciju veže se važan moment koji se uzima kao začetak bioetičke rasprave u Hrvatskoj, odnosi se na simpozij Izazovi bioetike održan 1998. godine u Cresu. Potonja pak manifestacija s vremenom postaje događaj međunarodnog značaja i središte znanstvene komunikacije u području bioetike u jugoistočnoj Europi (ibid.). Zajednica koja se okuplja oko ovih manifestacija počinje djelovati i u društvenom kontekstu oblikujući kritičke osvrte na pravno i društveno tretiranje nekih bioetičkih pitanja te postaje utjecajna zajednica koja okuplja znanstvenike i stručnjake različitih disciplina kao i zainteresiranu javnost i civilne udruge (ibid.). Takav pristup bavljenju bioetikom samom i bioetičkim pitanjima Ante Čović artikulira kao specifičnu koncepciju bioetike pod nazivom integrativna bioetika (ibid.).

Važnost distinkcije usmjerenja bioetike s moralne na etičku refleksiju i razvoja od nove medicinske etike do integrativne bioetike Čović (2011) je apostrofirao u članku koji se bavi pojmovnim razgraničenjima pojmova morala, etike, medicinske etike, bioetike i integrativne bioetike. Ta razgraničenja bit će relevantna za kritički osvrt na klasifikaciju u području bioetike pa će ovdje biti ukratko objašnjena. Čović (ibid., str. 12) moral određuje kao „mjerila prema kojem se [čovjek] treba ravnati i prosuđivati ispravnost svojih postupaka [...te ističe $\mathrm{da} \mathrm{tu}]$ refleksiju kojom se procjenjuje moralna ispravnost nakane nazivamo moralnom refleksijom“. Etika za razliku od toga „ima zadaću da teorijski objasni moral“ te ju Čović (ibid., str. 12) određuje kao refleksiju „o moralu koju nazivamo etičkom refleksijom“. Pritom razlikuje etičku refleksiju u širem smislu kao „razmišljanje o moralnom fenomenu“, od užeg smisla kao filozofsku etičku refleksiju (ibid., str. 13). Posebno ističe da je legitimno pričati o pluralizmu etičkih teorija i pozicija, ali da ne možemo nasuprot tome teorijski legitimno 
govoriti o pluralizmu moralnih pozicija tj. moralnom relativizmu (ibid.). Naposljetku, medicinsku etiku određuje kao područnu ili posebnu etiku (ibid.).

Čović (2011) uspostavlja opisana razgraničenja kako bi bioetiku opisao kao autonomnu disciplinu koja nije izrasla iz filozofske ili medicinske etike već kao područje koje izvire iz nove medicinske situacije kao što je opisuju Zagorac i Jurić (2008). Čović (2011, str. 18) smatra da su okolnosti nastanka bioetike pokazale „da orijentaciju u moralnim dilemama koje donosi znanstveno-tehnički napredak treba tražiti izvan znanosti same, u interakciji znanstvenih disciplina i izvanznanstvenih, etičkih i kulturnih perspektiva“.

Prema Čoviću (2011) razvoj područja bioetike može se organizirano prikazati u tri razvojne faze:

1. Razvojna faza „nove medicinske etike“ koju metodološki određuje neposredna moralna refleksija tj. principalizam $u$ užem kontekstu zdravstvene skrbi i biomedicinskih istraživanja;

2. Razvojna faza „globalne bioetike“ tj. već opisani stadij znanstvene interdisciplinarnosti i etičkog pluralizma u širem globalno-ekološkom i društvenopolitičkom kontekstu s proširenim predmetnim usmjerenjem na problematiku života;

3. Razvojna faza ,integrativne bioetike“ $\mathrm{u}$ kojem se područje određuje kao „pluriperspektivno područje u kojem se u interakciji raznorodnih perspektiva stvaraju uporišta za orijentaciju u pitanjima koja se odnose na život ili na uvjete njegova održanja“ (Čović, 2011, str. 21).

Ante Čović (2006) integrativnu bioetiku određuje u okviru pojma orijentacijskog znanja i kritike monoperspektivizma znanstveno-tehničke epohe. Perspektivnoj jednostranosti znanstveno-tehničke civilizacije suprotstavlja koncept pluriperspektivizma, no pritom objašnjava da on ne označava neku vrstu relativističkog perspektivizma. Naprotiv, ističe da se na perspektive ne može gledati kao na izolirane i istovrijedne načine sagledavanja nekog predmeta već zagovara ,perspektivizam koji podrazumijeva interaktivni, odnosno integrativni pluralizam perspektiva“ te da samo kao takav „,može s punim opravdanjem iskazati pretenzije na postizanje općevažećih spoznaja“ (ibid., str. 9). Perspektive dijeli na znanstvene, normativne i kulturne perspektive pri čemu pod znanstvenim perspektivama podrazumijeva empirijske i egzaktne znanstvene perspektive, pod normativnim smjerove i tradicije filozofske discipline i teologije, a pod kulturnim one perspektive čiji nositelji ,,mogu biti različiti protagonisti građanskog života, društveni pokreti, političke pozicije i programi, etablirani 
svjetonazori, religijske ustanove $i$ učenja, moralne refleksije, umjetnička ostvarenja $i$ programi, mediji, javno mnijenje itd. “(Čović, 2007, str. 73).

Ovako postavljen koncept integrativne bioetike bit će razmotren iz očišta organizacije znanja u poglavlju o primijenjenoj metodologiji ovog doktorskog rada, no kako bi ta analiza bila upućena potrebno je prvo razmotriti aktualne dosege u osiguranju predmetnog pristupa $u$ području bioetike. 


\section{Osiguranje predmetnog pristupa u području bioetike}

Za raspravu o klasifikaciji u području integrativne bioetike posebno su relevantni radovi koji se bave pojmovnim određenjem same bioetike. Prema Juriću (2011) ne postoji jedinstvena definicija bioetike već samo područje karakterizira pluralizam tumačenja koji će imati značajan utjecaj na oblikovanje načina klasificiranja njenih intelektualnih produkata. Jurić definicije bioetike dijeli u nekoliko skupina autora koji podržavaju ili su barem neko vrijeme podržavali neko specifično određenje područja bioetike. Ovdje navodimo ključne definicije tih pogleda prema kojima se bioetika može odrediti:

a) „kao disciplina koja se bavi pitanjima kliničke prakse, zdravstvenih sustava, bioloških, biomedicinskih i farmaceutskih istraživanja kao i drugim pitanjima ljudskog života i zdravlja uopće“ (Jurić, 2017, str. 128);

b) „kao interdisciplinarno zasnovana znanost o preživljavanju čiji je glavni cilj izgradnja mostova između humanistike i prirodnih znanosti“ (ibid., str. 128);

c) „kao dio filozofske etike, ili preciznije, kao grana primijenjene etike“ (ibid., str. 130)

d) kao „otvoreno područje susreta i dijaloga različitih znanosti i djelatnosti, te različitih pristupa $i$ pogleda na svijet, koji se okupljaju radi artikuliranja, diskutiranja $i$ rješavanja etičkih pitanja vezanih za život, život u cjelini $i$ u svakom od dijelova te cjeline, za život u svim njegovim oblicima, stupnjevima, fazama i pojavnostima.“ (ibid., str. 132)

Prva skupina definicija uočljivo je antropocentrična i zanemaruje pitanja prirode i okoliša u cjelini, a prema Juriću (2017) svodi bioetiku na novu medicinsku etiku i biomedicinsku etiku. Drugi set definicija proširuje opseg bioetike na globalno-ekološka pitanja i predstavlja začetak određenja bioetike koji područje ne ograničava na disciplinarna tumačenja. Kao kontrast tome Jurić (2017) pojašnjava i nelogičnosti pokušaja strogog disciplinarnog zasnivanja bioetike te na kraju nudi vlastitu definiciju bioetike čija je svrha prikazati da se složenost bioetike ne može ,proniknuti iz perspektive jedne znanosti ili jednog područja znanja“ (ibid., str. 132).

Jurić tvrdi da nije dovoljno odrediti tek teme ili samo područje bioetike već je potrebno smjestiti je i unutar okvira postojećeg sustava znanja i znanosti (ibid., str. 131). Zadatak koji time definira ima reperkusije i na smještaj bioetike u kontekstu neke opće klasifikacije i organizacije znanja. Jedan takav pokušaj klasifikacije lociramo u radu Renate Oštarić (2014) koja razmatra pitanje klasifikacije dokumenata u području medicinske etike, medicinske 
deontologije i bioetike u kontekstu Univerzalne decimalne klasifikacije. Cilj njene analize bio je utvrditi podudarnosti definicija područja s položajem u shemi UDK i formalnim klasifikacijama disciplina Nacionalnog vijeća za znanost Republike Hrvatske (ibid., 2014). Oštarić (2014) odmah na početku rada izjednačuje analizirana područja kao poddiscipline etike $\mathrm{i}$ to, konkretno, primijenjene etike. Bioetiku određuje u kontekstu prve skupine definicija koje navodi Jurić (2017), a time i pokazuje aktualnost Jurićeve analize jer, iako prepoznaje da se područja nalaze u stalnom stanju razvoja, inicijalno ne uzima u obzir ona određenja bioetike koja proširuju njen opseg ili koja ju definiraju kao interdisciplinarno područje znanosti. Ipak, povrh toga u prikazu povijesnog razvoja bioetike područje određuje pomoću rada Ivana Šegote za koga bioetika „uz medicinsko područje obuhvaća i druge oblasti života i različita područja znanosti“ (Oštarić, 2014). Pritom opet možemo reći da Jurić (2017) poentira ukazivanjem na nelogičnosti određenja bioetike kao ujedno stabilne samostalne discipline i onoga što Szostak i suradnici (2016) nazivaju interdisciplinom. Oštarić (2014) nadalje pojašnjava kako različiti izvori različito tretiraju sporna područja i odnose među njima te da to čini iznimne probleme za kategorizaciju određene discipline. U kontekstu nacionalne klasifikacije znanosti koju evidentno smatra relevantnom smjernicom za knjižničnu klasifikaciju iznosi stav da se problem određenja disciplina „više-manje uspješno ... pokušava riješiti uvođenjem kategorije interdisciplinarnosti“ (ibid., str. 189). Raspravu o klasificiranju u navedenim područjima Oštarić (2014) pokreće zbog promjena u podskupini 60 koja se odnosi na opća pitanja primijenjenih znanosti i biotehnologije koja sada specificira i bioetiku pod 608.1 Etički aspekt. Bioetika. Ovaj primjer također ukazuje na usko disciplinarno određenje bioetike $\mathrm{i}$ to $\mathrm{k}$ tome još $\mathrm{uz}$ neraskidivu hijerarhijsku vezu $\mathrm{s}$ tehnologijom. O naravi klasifikacije bioetike zaključuje na temelju primjera iz prakse koje kritizira kao ,pojednostavljivanje bioetike ... na različita etička pitanja u medicinskoj znanosti“ (ibid., str. 195) te kao alternativu tome preferira korištenje prethodno spomenutog određenja bioetike kao podskupine područja primijenjene znanosti. Rad Oštarić važan je jer ukazuje na utabane disciplinarne obrasce tj. posljedice disciplinarne klasifikacije koja izravno šteti ekspresivnosti i primjerenosti klasifikacije u interdisciplinarnim područjima znanosti, ali i problem da se oni upućeni u terminološka razgraničenja moraju zadovoljiti uskim disciplinarnim određenjima područja s čijom se zahtjevnom interdisciplinarnošću ili kako navodi Oštarić (ibid., str. 197) „uzajamnom inkluzivnom referentnošću“ susreću u svakodnevnom klasifikacijskom radu. 
Analiza koju nudi Oštarić (2014) praktična je u mjeri u kojoj klasifikacija ima tek sporedni interes podržati informacijske potrebe interdisciplinarnih i transdisciplinarnih istraživača, ali i tada ograničeno. Ključni problem leži upravo u ustrajanju na disciplinarnim određenjima i operiranju s konceptom disciplina koje se istovremeno isprepliću, dok nastoje utemeljiti vlastitu različitost i samostalnost. Disciplinarne klasifikacije postaju provizorne zbog nemogućnosti jasnog definiranja odnosa među konceptima koje popisuju, a usmjeravaju se na neproduktivnu hijerarhizaciju područja isprepletenih prema fenomenima koje proučavaju, teorijskim, metodološkim i drugim odrednicama.

U području bioetike dostupno je nekoliko opsežnijih sustava za organizaciju znanja. Kako bi potreba za interdisciplinarnom i transdisciplinarnom organizacijom znanja bila potpuno uspostavljena potrebno je istaknuti karakteristike, ali i nedostatke postojećih sustava za organizaciju znanja u samom području. Prije prikaza samih sustava za organizaciju znanja treba napomenuti da su brojni sustavi koji se tiču kontroliranih rječnika relevantnih za područje bioetike navedeni i dostupni putem skupne baze sustava za organizaciju znanja BARTOC. Ipak, riječ je o sustavima koji se skupno odnose na znanosti o životu (engl. life sciences) pa je tako nekolicina postojećih rječnika fokusiranih na područje bioetike zavedena, i dapače prikrivena, među rječnicima koji se odnose primjerice na područje biologije, a koje je tradicionalno izrazito klasifikacijski zanimljivo i produktivno područje. Usmjerimo li pretraživanje rječnika na samo područje bioetike pronaći ćemo svega pet sustava različite specifičnosti:

- Klasifikacija bioetičke istraživačke knjižnice Kennedy Instituta za etiku koji djeluje pri Sveučilištu u Georgetownu;

- Bioetički tezaurus iste institucije;

- Tezaurus bioetike na talijanskom jeziku

- Tezaurus „Etika u znanostima o životu“ Njemačkog referalnog centra za etiku u bioznanostima te;

- Rječnik kliničkih lijekova

\section{Alati Kennedy Instituta za etiku}

Prva dva navedena sustava rezultat su rada iste institucije tj. Kennedy Instituta za etiku koji djeluje pri Sveučilištu u Georgetownu pri čemu je tezaurus rezultat projekta BioethicsLine koji po nalogu američke Nacionalne medicinske knjižnice okuplja literaturu o bioetičkim pitanjima od 1972. do 1999. godine (BioethicsLine, 2021). Cilj projekta bio je pripremiti 
literaturu za uključivanje u MEDLARS (Medical Literature Analysis and Retrieval System) tj. jednu od glavnih akademskih baza podataka u području medicine koja je poznatija u svojoj online inačici kao MEDLINE, a danas je dostupna preko digitalnih servisa Sveučilišta u Georgetownu. Tezaurus bioetike stvoren je prema aktualnim standardima za konstrukciju tezaurusa i moguće ga je pretraživati u dokumentu koji donosi abecedni popis 745 preferiranih i kontroliranih termina. Uvidom u detaljne i strukturirane podatke o revizijama tezaurusa posljednja promjena evidentirana je 2012. godine, a isti dokument $u$ tabličnom obliku evidentira sve deskriptore $\mathrm{i}$ nedeskriptore $\mathrm{u}$ abecednom rasporedu, definira hijerarhijske odnose termina (šire i uže termine), srodne termine, godinu uvođenja i revizije bilješki te donosi povijesne zabilješke i bilješke o opsegu deskriptora.

Tezaurus bioetike Kennedy Instituta za etiku široko je i multidisciplinarno postavljen sustav za označivanje dokumenata koji je ograničen jamstvom predloška, odnosno literature koju indeksira. Indikativno je da detaljna tabela koja dubinski prikazuje strukturu tezaurusa tek za svega nekoliko termina evidentira poveznice s Klasifikacijskom shemom bioetičke istraživačke knjižnice istog instituta. Prema Szostaku i suradnicima (2016) nemogućnost povezivanja ovakvih disciplinarno orijentiranih sustava s općim klasifikacijama znanja ključno je ograničenje za njihovu primjenu u interdisciplinarnom i transdisciplinarnom kontekstu. Primjena tezaurusa bioetike opisana je u dokumentu iz 1992. godine koji potpisuje američki Nacionalni referalni centar za bioetičku literaturu (NRCBL, 1992) gdje se objašnjava da će dokumenti biti opisani setom deskriptora iz tezaurusa bioetike kao i način njihovog pretraživanja. Za set dodijeljenih deskriptora ne definiraju se daljnje vrste semantičkih odnosa što je reminiscentno na tvrdnju Biagetti (2021) da je literatura koju predmetno opisujemo pomoću tezaurusa opisana tek uskim setom tezauralnih odnosa. Pritom poentira da druge vrste sustava, poput ontologija, omogućavaju izrazito veću ekspresivnost semantičkih odnosa.

Spomenuti drugi alat tj. Klasifikacijska shema bioetičke istraživačke knjižnice Kennedy Instituta za etiku (Prilog 1) usustavljena je u 22 predmetna područja. Klasifikacija je osmišljena kao decimalna klasifikacija koja pojedine predmete označava numeričkom notacijom pomoću koje se oblikuje hijerarhijski niz. Notacija je, u načelu, maksimalno trorazinska i stvorena tako da se na svakoj razini podjele koristi niz jednoznamenkastih ili dvoznamenkastih brojeva pa je tako moguća notacija 22.3 Biotehnologija - Životinje ili 1.3.11 Proizvodnja životinja. Iako se to ne specificira, čini se da je sama klasifikacija osmišljena primarno za svrhu organizacije knjiga na policama. Pogledamo li pobliže korištenu notaciju 
zamijetit ćemo da se u okviru pojedinih predmetnih područja kao npr. područja 1.1 Filozofska etika, navodi niz tome području pripadajućih termina koji nose podjednaku notaciju. Primjerice:

\title{
1.1 FILOZOFSKA ETIKA
}

\author{
$1.1 \ldots \ldots \ldots \ldots$ Autonomija (Autonomy) \\ $1.1 \ldots \ldots \ldots \ldots$...... Dobrobit (Beneficence) \\ $1.1 \ldots \ldots \ldots \ldots$ Skrbi, Etika (Care, Ethics of) \\ $1.1 \ldots \ldots \ldots \ldots$....... Skrb (filozofska) (Care, philosophical) \\ $1.1 \ldots \ldots \ldots$ Kazuistika (Casuistry) \\ $1.1 \ldots \ldots \ldots \ldots$ Konfucijanizam (Confucianism) \\ $1.1 ; 7.1(7.2)$... Humanizam (Humanism)
}

Takav način klasificiranja može biti problematičan kada je potrebno uspostaviti jasna razgraničenja između koncepata jer su koncepti evidentno različitog opsega klasificirani pod istom oznakom. U kontekstu ove klasifikacije indikativan je primjer zajedničkog označavanja termina feminizam i incest klasifikacijskim brojem skupine pod brojem 10 koja označava područje seksualnosti. O razlici u opsegu značenja spomenutih termina nije potrebno posebno govoriti, no pojavu da se feminizam kao ideologija i društveni pokret klasificira na istoj razini kao i specifična vrsta seksualne aktivnosti treba uzeti kao pokazatelj da ova klasifikacija ne polazi od koncepta jamstva i to specifično onih vrsta jamstava poput tzv. akademskog jamstva ili obrazovnog jamstva koje u disciplinarnim klasifikacijama osiguravaju da je znanje organizirano prema aktualnim epistemičkim dosezima neke discipline i da reflektira konsenzus stručnjaka o značenjima disciplinarnih termina i njihovim međuodnosima (cf. Barité, 2018).

Kod nekih predmeta može se pronaći i dodatna ili druga notacija koja je djelomično objašnjena kratkom uputom da se klasifikacijski brojevi u zagradama mogu koristiti za rafiniranje rezultata pretraživanja prilikom korištenja sustava za pretraživanje informacija koji koristi ova knjižnica, a da je svakom dokumentu pridružen samo jedan glavni klasifikacijski broj. Pogledamo li primjer humanizma dodatni brojevi kojim je opisan upućuju na područja 7.1 Opće koji se nalazi u području 7 Sociologija zdravstva i 7.2 Obrazovanje zdravstvenih djelatnika. Razlozi takvog upućivanja nisu jasni, a na strukturnoj razini nije moguće zaključiti 
koja je razlika klasificiranja nekog djela pod 2 Bioetika ili 2.1 Opće koje se doimaju kao kategorije podjednakog opsega.

Drugim riječima, ova klasifikacija ne koristi notaciju u klasičnom smislu kako ga pojmi područje organizacije znanja te to onemogućuje širu primjenu ove klasifikacije izvan konkretnog konteksta i lokalne svrhe za koju je zamišljena te na koju je primijenjena. Ipak, treba također zamijetiti da ovakva vrsta nediverzificiranog bilježenja i konstrukcije sheme predmeta ima ograničenu snagu u osiguranju predmetnog pristupa bez obzira na kontekst aplikacije.

Klasifikacija u uvodnom pojašnjenju tvrdi da su predmeti strukturirani od općih prema specifičnima, no iako klasifikacija kreće od područja filozofije, etike i bioetike kao što to između ostalog čine i brojne druge klasifikacije (npr. UDK), ova klasifikacija brzo odustaje od toga načela pa se tako pojam abortusa može naći kao prethodeći pojam području genetike ili problemu eksperimenata nad ljudima.

Gledana u cjelini Klasifikacija bioetičke istraživačke knjižnice Kennedy Instituta u Georgetownu lokalna je i izrazito disciplinarno orijentirana klasifikacija koja bioetiku vidi definiranu isključivo u odnosu spram medicine i interesa znanstvenika i stručnjaka u tome području. Kao argument za takvu tvrdnju može se uzeti primjer abortusa u kojem se ne specificira medicinski pogled već se pod pojmom abortus specificira mogućnost postojanja literature o moralnim ili religijskim aspektima, pravnim aspektima ili društvenim aspektima pobačaja. Znanstveni, disciplinarni pogled na pitanje abortusa unaprijed je pretpostavljen. Klasifikacija je posljednji put revidirana 2010. godine.

\section{Tezaurus bioetike na talijanskom jeziku}

Monolingvalni tezaurus bioetike na talijanskom jeziku (SIBI, 2021) stvoren je na temelju jamstva predloška talijanske bioetičke produkcije od 1995. do 2006. godine. Rezultat je projekta SIBIL koji se bavio uspostavom mrežne informacijske infrastrukture za područje bioetike, no trenutno nije jasno u kojem je stanju sam tezaurus jer mu je onemogućen pristup.

Tezaurus „Etika u znanostima o životu“ Njemačkog referalnog centra za etiku u bioznanostima

Multilingvalni tezaurus „Etika u znanostima o životu“ Njemačkog referalnog centra za etiku u bioznanostima (DRZE, 2021) jedini je od pronađenih rječnika koji u svojoj definiciji prepoznaje heterogenost i multidisciplinarnost područja bioetike, a koji pritom kao ciljanu publiku ovog alata uz stručnu zajednicu vidi i građanstvo općenito . Posljednje izdanje 
objavljeno je 2012. godine (DRZE, 2021). Uz rječnik predstavljen je i sistematski popis signatura za organizaciju knjiga na policama specijalne knjižnice instituta. Ovaj tezaurus izrastao je 1999. godine iz projekta referalnog centra čiji je cilj bio udružiti snage njemačkih, francuskih i američkih referalnih institucija koje svoju djelatnost identificiraju u kontekstu znanosti o životu (ibid.). Može se sa relativnom sigurnošću tvrditi da je riječ o tematski najširem tezaurusu jer nadilazi antropocentrični pristup i strogo usmjerenje na medicinsku etiku te obuhvaća životinjsku etiku, etiku okoliša, poljoprivrede, genetičko inženjerstvo i biotehnologiju (ibid.). Urednički tim trenutno radi na razvoju konkordansi s drugim referentnim tezaurusima u područjima koja pripadaju tematskom opsegu tezaurusa. U opisu tezaurusa pojašnjava se da su područja biologije, medicine i genetike posebno razrađena jer su bliska fokusu tezaurusa, dok su ostala područja okupljena u područje koje se općenito odnosi na znanost, tehnologiju i istraživanja (ibid.). Tezaurus je podijeljen u 14 predmetnih područja, a deskriptori su birani prema „bioetičkoj relevantnosti“ te se u opisu argumentira da ,ne postoji univerzalno primjenjiv princip izbora, [a] selekcija deskriptora i njihove lokacije $u$ predmetnom području u mnogim je slučajevima temeljena na kompromisu između perspektiva i potreba pojedinih disciplina i praktičkih zahtjeva korisnika“ (ibid.). Prema Szostaku i suradnicima (2016) ako se organizacija znanja promišlja interdisciplinarno, univerzalni princip koji određuje mjesto koncepata u općoj shemi možemo crpiti iz teorije integrativnih razina. Vrlo je važno zamijetiti da opisani tezaurus čini jasna razgraničenja između disciplinarne terminologije pojedinih disciplina te se isto koristi kao argument za višestruko uvrštavanje istih deskriptora kako bi se prikazala pripadnost istog termina pojedinoj disciplini $^{38}$ (DRZE, 2021). Pridružimo li tome već izražene primjedbe o ograničenoj ekspresivnosti semantičkih odnosa u tezaurusima možemo zaključiti da ni najsofisticiraniji postojeći sustavi u području bioetike ne pružaju potpunu podršku reprezentaciji znanja koja se generiraju u interdisciplinarnom i transdisciplinarnom kontekstu. Kada govorimo o prikazu interdisciplinarnosti i transdisciplinarnosti ovaj tezaurus interdisciplinarne pristupa organizira nestrukturirano u pomoćni popis općih termina, dok se transdisciplinarni termini kontroliraju kao istoznačnica za interdisciplinarne pristupe.

\section{Rječnik kliničkih lijekova}

Posljednji rječnik s popisa (BARTOC, 2021) odnosi se na visoko specijalizirani rječnik kliničkih lijekova koji umjesto u bioetike u fokus stavlja na klinička ispitivanja lijekova i srodne discipline poput biostatistike, farmakologije i epidemiologije javnog zdravlja pri čemu

\footnotetext{
${ }^{38} \mathrm{Ti}$ su termini dodatno povezani definiranjem odnosa srodnosti između njih.
} 
su bioetički termini birani u odnosu na disciplinarne potrebe navedenih područja. Sam opis rječnika navodi da su primarni korisnici liječnici, farmakolozi, epidemiolozi, dokumentalisti, studenti, prevoditelji specijaliziranih tekstova itd.

\section{PhilPapers.org}

Uz navedene sustave, postoji i nekoliko manje strukturiranih bibliografskih baza koje definiraju predmetne kategorije za područje bioetike nekih specijaliziranih institucija. Zamjetljivo je da su dominantni izvori terminologije za sve navedene tezauruse prvenstveno medicina, ali i filozofija. Usmjerimo li se na sustave koji osiguravaju predmetni pristup literaturi u području filozofije možemo uočiti još jedan zanimljiv primjer sustava koji okuplja bioetički relevantnu literaturu. Riječ je o sveobuhvatnoj indeksnoj bibliografskoj bazi PhilPapers (2021) koju uređuju stručnjaci iz područja filozofije i koja je jedan od najrelevantnijih izvora literature za područje filozofije. Iako sama baza indeksira niz članaka iz područja bioetike u izrazito kompleksnoj kategorizacijskoj strukturi još uvijek ne predviđa zasebnu kategoriju za bioetiku. Umjesto toga, bioetička literatura općenito, raspršena je po kategorijama medicinske etike, biomedicinske etike, reproduktivne etike i drugim kategorijama primijenjene etike. Kada govorimo o specifično integrativno bioetičkoj literaturi možemo ju pronaći u kategorijama primijenjene etike, etike općenito ili kao nekategorizirane jedinice literature. 


\section{METODE DOKTORSKOG ISTRAŽIVANJA}

U poglavlju o metodama doktorskog istraživanja bit će objašnjen metodološki okvir poduzetih postupaka. Istraživanje se predstavlja u kontekstu analize domene kao sveobuhvatnog metodološkog obrasca informacijskih i komunikacijskih znanosti. Objašnjavaju se ciljevi i istraživačka pitanja.

Predstavljanje metodologije strukturirano je u cjeline koje objašnjavaju način uzorkovanja literature u području integrativne bioetike prema sistemu PRISMA instrumenta (Moher et al., 2009), polazišta u bibliometrijskoj analizi uzorka i vrstu poduzete analize sadržaja koja je podređena svrsi izrade osnove za klasifikaciju područja integrativne bioetike na temelju Klasifikacije integrativnih razina. Na kraju poglavlja objašnjavaju se ograničenja primijenjene metodologije. 


\section{Analiza domene: slučaj integrativna bioetika}

Osiguranje jamstva perspektive i interoperabilnosti sustava za organizaciju znanja uočeni su kao temeljne zadaće organizacije znanja i informacijskih znanosti u cjelini. Temeljna orijentacija na specifične domene znanja i istraživanje informacijskih potreba i zahtjeva unutar njih (Hjørland, 2021) nije napuštena i ostaje aktualna čak i u okviru zagovora univerzalnih sustava. Gnolijev i Szostakov treći put pred organizaciju znanja postavlja jasan zadatak uparivanja ontoloških i epistemoloških pristupa koji klasifikaciju vidi kao visoko strukturiranu heuristiku koja, iako inspirirana filozofskom ontologijom, ostaje svjesna nužnosti pragmatičke i funkcionalističke orijentacije svakog sustava za organizaciju znanja. Klasifikacija, bila opća ili specifična, uvijek mora služiti nekoj većoj ili manjoj zajednici ljudi.

Cilj je ove disertacije pridonijeti definiciji transdisciplinarne organizacije znanja te na primjeru osiguranja jamstva perspektive u specifičnom području integrativne bioetike pridonijeti razvoju područja analize domene. Smiraglia (2015) u metodološkom priručniku o analizi domene i ekstrakciji domenskih ontologija navodi da je do sada istraženo 42 dvije domene, od kojih je njih dvanaest istraženo dva ili više puta, dok su sve ostale istraživane jednom. Ova disertacija na popis domensko-analitički istraženih područja pridodat će i integrativnu bioetiku.

Hjørland (2002) definira već spomenutih jedanaest pristupa za analizu domene. Njegov popis nije konačan, već služi kao objašnjenje vrste metodologija za koje smatra da su primjereni za cilj nove paradigme. To su:

1. Stvaranje vodiča kroz literaturu i predmetnih imenika

2. Konstrukcija specijalnih klasifikacija i tezaurusa

3. Studije indeksiranih informacija i načina facilitiranja pretraživanja informacija $u$ specifičnim područjima

4. Empirijske studija korisnika

5. Bibliometrijske studije

6. Povijesne studije

7. Studije dokumenata i žanra

8. Epistemološke i kritičke studije

9. Terminološke studije, jezik za posebne namjene (engl. language for special purposes i.e. LSP), semantičke analize baza podataka i studije diskursa 
10. Studije struktura i institucija u znanstvenoj komunikaciji

11. Analiza znanstvene kognicije, ekspertnog znanja i umjetne inteligencije

Ova studija kombinira kvantitativne i kvalitativne pristupe i spada u istraživanja miješane metodologije (engl. mixed-method research). Razlog odabira toga pristupa leži u potrebi cjelovitog i sustavnog opisa domene koja se želi uhvatiti u koštac s manom redukcionizma koja mori istraživanja isključivo usmjerena na kvantitativne metodološke postupke i analize. Od predloženih metoda za analizu domene koristit će se aspekti sljedećih pristupa $\mathrm{s}$ Hjørlandova popisa: konstrukcija specijalnih klasifikacija, bibliometrijske studije, studije načina indeksiranih informacija, studije diskursa, epistemološke studije, studije struktura i institucija u znanstvenoj komunikaciji i analiza ekspertnog znanja. U svim navedenim aspektima tražit će se prilike za vizualizaciju domene sukladno metodološkim zakonitostima pojedina pristupa te u skladu s prijedlozima za vizualizaciju domena koje navodi Smiragli (2015) u metodološkom priručniku za analizu domene.

Iako se razlog istraživanja neke domene znanja u okviru paradigme analize domene može opravdati naprosto namjerom doprinosa razumijevanju još jednog segmenta ljudskih znanstveno-diskurzivnih aktivnosti, područje integrativne bioetike može se razmatrati kao posebno potentno područje za analizu domene jer je za nju ključno da se njene fenomene, bioetička pitanja, može razmatrati iz niza alternativnih perspektiva. Dok je pretpostavka pluraliteta perspektiva obično tek jedno od sporednih obilježja drugih područja, specifična konceptualizacija integrativne bioetike oblikuje istančanu potrebu za pluri-perspektivnom organizacijom znanja koja će očuvati razlučivost integrativnog pluralizma perspektiva koje sudjeluju u potpunoj karakterizaciji bioetičkih fenomena. Zamjetljiva je i određena podudarnost definicije pluriperspektivizma i perspektivistički zasnovane organizacije znanja koja se očituje ponajprije u sljedećem:

- kritici dominantnosti disciplinarnih perspektiva u organizaciji znanja tj. kritici perspektivne jednostranosti i perspektivnog redukcionizma znanstveno-tehničke civilizacije u teoriji integrativne bioetike;

- ideji jamstva perspektive u organizaciji znanja tj. potrebi identifikacije perspektiva u interakciji za potpuniju karakterizaciju bioetičkih fenomena u integrativnoj bioetici;

- njihovom interdisciplinarnom i transdisciplinarnom temelju;

- zagovoru slobodno fasetiziranih pristupa klasifikaciji koji omogućuju da je reprezentirana perspektiva svakoga tj. zagovoru pluriperspektivizma kao inovativnog 
metodološkog obrasca za konceptualizaciju bioetičkih fenomena u integrativnoj bioetici;

- univerzalističkoj orijentaciji klasifikacija fenomena kao „mjesta za sve“ (Szostak, 2014) tj. monističkom tretmanu istine u području integrativne bioetike;

- kritičkom odnosu prema svim oblicima epistemičkog relativizma.

$\mathrm{Na}$ temelju pregleda teorijskih dosega organizacije znanja i integrativne bioetike te metodološke literature o analizi domene, klasifikaciji i pluriperspektivizmu ova disertacija polazit će od sljedećih istraživačkih pitanja:

1. Koja je definicija jamstva perspektive u transdisciplinarnoj organizaciji znanja?

2. Kako bibliometrijske varijable dokumenata strukturiraju zabilježeno znanje u domeni integrativne bioetike?

3. Kakva struktura bioetičkih fenomena i perspektiva koje ih interaktivno opisuju postoji u području integrativne bioetike?

Ta pitanja oblikuju sljedeće istraživačke ciljeve:

- odrediti konceptualne doprinose područja organizacije znanja i integrativne bioetike problemu osiguranja jamstva perspektive u transdisciplinarnoj organizaciji znanja

- istražiti bibliometrijska obilježja dokumenata u području integrativne bioetike

- izraditi osnovu za sustav za organizaciju znanja koji će reprezentirati međuodnose fenomena i perspektiva u području integrativne bioetike

Definirana istraživačka pitanja i ciljevi upućuju na istraživačke postupke koji će se ovdje enumerirati u općenitom smislu, a potom pojasniti u zasebnim potpoglavljima ovog prikaza metodologije disertacije.

Primijenjeni istraživački postupci u ovoj disertaciji su sljedeći:

1. Priprema istraživačkog materijala tj. literature područja integrativne bioetike prema sistemu PRISMA instrumenta Moher et al. (2009)

2. Deskriptivna bibliometrijska analiza područja integrativne bioetike

3. Analiza sadržaja produkcije članaka u području integrativne bioetike

4. Fasetna analiza tema članaka u području integrativne bioetike 
Potrebno je napomenuti da je prvi cilj koji se odnosi na definiciju jamstva perspektive u transdisciplinarnoj organizaciji znanja već djelomično ostvaren i u prethodno iznesenom pregledu literature o toj problematici, a dodatna konceptualizacija jamstva perspektive bit će prezentirana u diskusijskom dijelu rada kada će se postavke integrativne bioetike, rezultati bibliometrijskog istraživanja i provedenih analiza sadržaja upariti s opisanim teorijskim i metodološkim dosezima u području organizacije znanja.

Istraživanje će se ograničiti na izgradnju osnove za organizaciju znanja u području integrativne bioetike $\mathrm{i}$ opis područja na temelju bibliometrijskih varijabli te stoga neće utvrđivati narav strategija pretraživanja informacija integrativnih bioetičara, niti narav kognitivnog rada i organizacije poslovnog prostora kakav je srodan drugim vrstama sociološki zasnovanih metodologija. To ukazuje na to da je analiza domene u području integrativne bioetike podobna i za brojne druge vrste istraživanja koje bi mogle doprinijeti konstituciji i objašnjenju domene u budućnosti.

S obzirom na opisane prednosti klasifikacije fenomena analiza sadržaja i konstrukcija osnove za izgradnju sustava za organizaciju znanja koju se poduzima u ovoj disertaciji temeljit će se na Klasifikaciji integrativnih razina jer samo ona nudi mogućnost da se različiti uvidi okupljaju oko relevantnih fenomena kojima se specifične i slobodno organizirajuće interdisciplinarne i transdisciplinarne zajednice istraživača žele baviti. Sljedeće poglavlje govori o načinu konstrukcije uzorka literature za analizu, specifičnim bibliometrijskim varijablama i aspektima sadržaja dokumenata koje će se istraživati. 


\section{Priprema istraživačkog materijala tj. literature područja integrativne bioetike prema sistemu PRISMA instrumenta Moher et al. (2009)}

U svrhu sustavne pripreme istraživačkog materijala korišten je PRISMA instrument (Moher et al., 2009). PRISMA instrument sastoji se od liste koja popisuje 27 postupaka za svako sistematično istraživanje literature koje ima namjeru podvrgnuti identificirani set izvora kvalitativnim ili kvantitativnim istraživačkim postupcima. Razvijen je u okviru medicinskih znanosti, no primjenjiv je na sva istraživanja čiji je cilj transparentno izvještavanje o sustavnim pregledima literature i njenoj meta-analizi. Postupci koje propisuje PRISMA instrument organizirani su u četiri faze:

1. Identifikacija izvora

2. Provjera izvora

3. Utvrđivanje sukladnosti izvora s kriterijima uključivanja

4. Uključivanje izvora

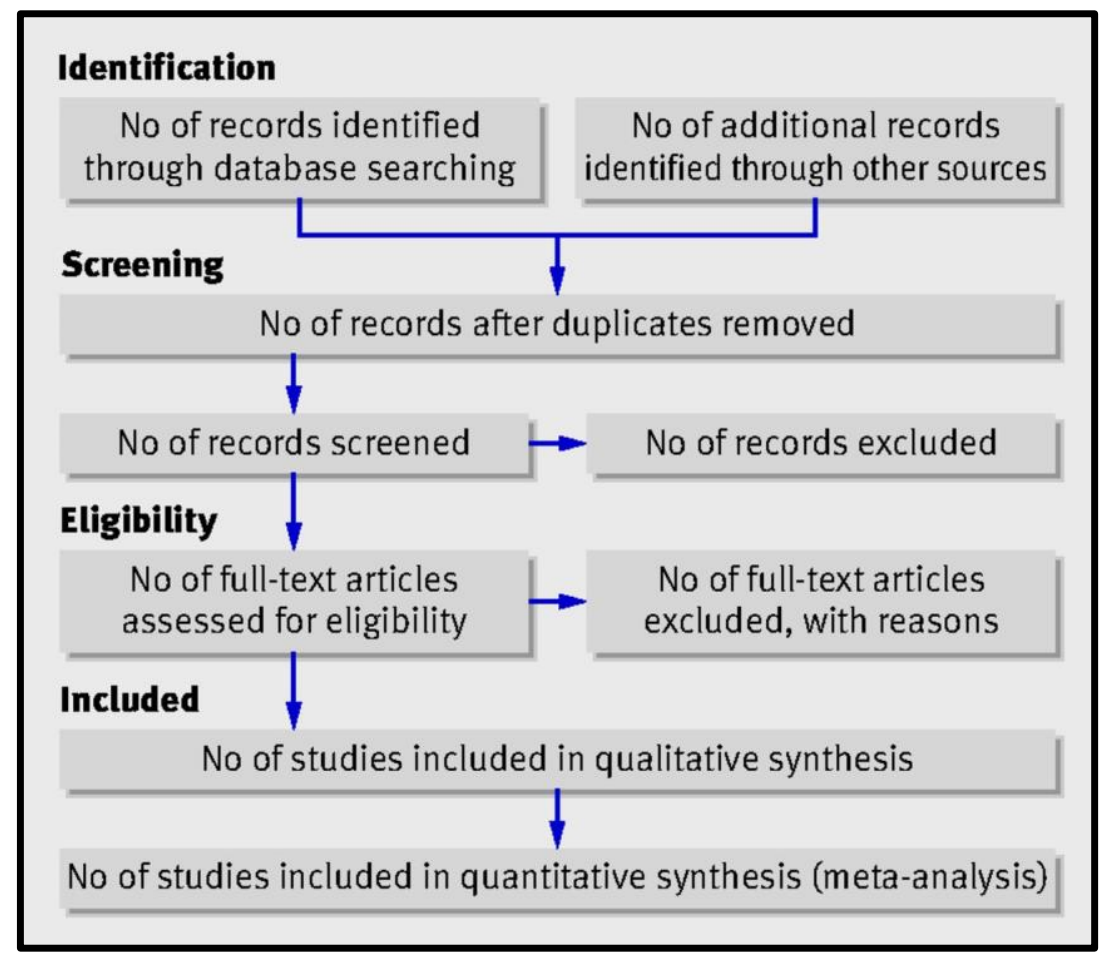

Slika 6. Primjer algoritma istraživačkog postupka za kvalitativno i kvantitativno istraživanje cjelovitog teksta nekog zamišljenog seta znanstvenih istraživanja (Moher et al., 2009)

Istraživački materijal pripremljen je zaključno s 30. kolovozom 2018. godine kada je analitička faza doktorskog istraživanja započeta. 


\section{Identifikacija izvora tj. obuhvaćene baze podataka}

Istraživački materijal pripremljen je pretraživanjem i preuzimanjem podataka iz pet znanstveno-akademskih indeksnih ili citatnih baza podataka. Istraživački materijal čine podaci i tekstovi iz baza podataka SCOPUS, Web of Science, Google Znalac, Hrvatske znanstvene bibliografije (CROSBI) i Portala hrvatskih znanstvenih $i$ stručnih časopisa (HRČAK). U nastavku su dana objašnjenja za uključivanje pojedine baze podataka, pojašnjenja načina oblikovanja upita, obuhvaćeni rasponi godišta, kriteriji inkluzije i ekskluzije pojedinog izvora kao i podaci o broju uključenih izvora prema bazama podataka, vrsti izvora i drugim relevantnim dimenzijama.

\section{Kriteriji za odabir baza podataka prema mogućnostima oblikovanja upita za pretraživanje}

Upiti postavljeni bazama podataka odabranim za prikupljanje istraživačkog materijala sadržavali su pojam integrativna bioetika u različitim oblicima riječi, a pretraživana su sva dostupna tekstualna polja i cjeloviti tekst ako su funkcionalnosti sustava za pretraživanje odabranih baza podataka to omogućavale. Početna godišta koje obuhvaća pojedina baza podataka razlikuju se od baze do baze, no kao završna godina uzeta je 2018. godina kada je priprema istraživačkog materijala završena. Tabela 3. pokazuje kriterije oblikovanja upita i obuhvaćena godišta prema bazama podataka.

Tabela 3. Pregled mogućnosti oblikovanja upita i obuhvaćenih godišta s obzirom na bazu podataka

\begin{tabular}{|l|l|l|l|l|}
\hline $\begin{array}{l}\text { Baza } \\
\text { podataka }\end{array}$ & $\begin{array}{l}\text { Kriterij "Varijante } \\
\text { oblika riječi" }\end{array}$ & $\begin{array}{l}\text { Kriterij "Sva } \\
\text { tekstualna polja" }\end{array}$ & $\begin{array}{l}\text { Kriterij } \\
\text { "Cjeloviti tekst" }\end{array}$ & $\begin{array}{l}\text { Obuhvaćene } \\
\text { godine }\end{array}$ \\
\hline SCOPUS & $\mathrm{Da}$ & $\mathrm{Da}$ & $\mathrm{Ne}$ & $1960-2018$ \\
\hline $\mathrm{WoS}$ & $\mathrm{Da}$ & $\mathrm{Da}$ & $\mathrm{Ne}$ & $1955-2018$ \\
\hline $\begin{array}{l}\text { Google } \\
\text { Scholar }\end{array}$ & $\mathrm{Da}^{39}$ & $\mathrm{Da}$ & $\mathrm{Da}$ & $1911^{40}-2018$ \\
\hline HRČAK & $\mathrm{Da}$ & $\mathrm{Da}$ & $\mathrm{Da}$ & $1870-2018$ \\
\hline CROSBI & $\mathrm{Da}$ & $\mathrm{Da}$ & $\mathrm{Ne}$ & $2005-2018$ \\
\hline
\end{tabular}

\footnotetext{
39 Pretraživač sam pretražuje različite varijante upisanih pojmova, dok je u ostalim bazama pretraživanje varijanti uređeno posebnim operatorima skraćivanja (engl. truncation).

40 Godina prvog izvora koji baza locira prema postavljenom upitu, no prvi rad iz ove baze primjeren za uključivanje dolazi tek iz 2005. godine.
} 


\section{SCOPUS i WoS}

Baza SCOPUS primarno je citatna baza internacionalnog karaktera, a pretraživana je s namjerom fokusiranog pretraživanja literature koja se bavi konceptom integrativne bioetike. Ni SCOPUS, ni WoS ne omogućuju pretraživanja cjelovitog teksta pa su pretraživana sva dostupna tekstualna polja pomoću operatora za skraćivanje i operatora za definiranje tj. fiksiranje redoslijeda pretraživanih termina. Postavke upita osigurale su da varijante riječi integrativna moraju prethoditi riječi bioetika bez mogućnosti da se među njima nađe neka druga riječ. U bazi SCOPUS to je učinjeno operatorom „PRE/0“, dok se u WoS-u, zbog ograničenja u formulaciji upita koja proizlazi iz tehničke nemogućnosti sustava da se u upitu definira točan redoslijed varijanti, koristio operator blizine „NEAR/0“ kojim se postiže da riječi moraju stajati jedna do druge.

\section{Google Znalac}

Potraga za literaturom provedena je i u bazi Google Znalac. Prilikom pretraživanja baze Google Znalac polazi se od istraživanja i rasprave o upitnoj kvaliteti njenih podataka. Prema utjecajnoj istraživačici kvalitete Google Znalca, Anne-Wil Harzing, prilikom pretraživanja i temeljenja istraživanja na toj bazi potrebno je imati na umu da Google Znalac ponekad uključuje citate neakademskih izvora, da njegova pokrivenost varira s obzirom na obuhvaćena područja, da je kvaliteta podataka niža za starije izvore, da se ne osvježava jednako često kao komparabilne baze (primarno Thomson ISI Web of Knowledge) te da često nudi loše indeksirane ili čak besmislene podatke (Harzing, van der Wal, 2008). Ipak, Harzing navodi da njena istraživanja pokazuju da Google Znalac nudi cjelovitiju sliku specifičnih područja od komparabilnih baza (ibid.). S obzirom na sveobuhvatnost Google Znalca u ovo istraživanje ta je baza uključena na temelju potrebe što cjelovitijeg prikaza domene znanja integrativne bioetike. Adler i Harzing (2009) napominju da njihova istraživanja u području menadžmenta pokazuju jezičnu pristranost i orijentiranost komparabilnih baza (primarno proizvodi Thomson Reutersa) na engleski jezik u odnosu na druge svjetske jezike. Usto, relevantni su i njihovi zaključci (ibid.) koji kritički razmatraju orijentiranost komparabilnih baza na indeksiranje časopisa koji streme internacionalnom profilu, što prema autoricama uzrokuje da se produkcija nacionalno orijentiranih časopisa u komparabilnim bazama prikazuje samo u onoj mjeri u kojoj ti časopisi streme internacionalizaciji, što značajan dio svjetske znanstvene produkcije čini nevidljivim. Google Znalac je, stoga, uključen u ovo istraživanje kako bi se 
prikazala što vjernija slika hrvatske nacionalne znanstveno-stručne produkcije u području integrativne bioetike.

Pretraživanja baze Google Znalca provedena su s posebnim ograničenjem „,site:hrcak.srce.hr“ zbog tehničkog problema s načinom na koji Google-ovi alati za indeksiranje web stranica (engl. web crawler) skupljaju podatke s HRČKA. Naime, zbog toga što je na korisničkom sučelju HRČKA, u okviru padajućeg izbornika, integrativna bioetika navedena kao interdisciplinarno područje znanosti, pretraživanje za istraživano područje na Google Znalcu povlači sve zapise s HRČKA neovisno o području. Umjesto da se podaci pobiru iz same baze, pobiru se s korisničkoga sučelja. Isključivanjem cijele mrežne domene na kojoj se nalazi HRČAK dolazi se do podataka Google Znalca kojima je moguće upravljati i nad kojima je moguće provesti sve daljnje potrebne korake prilagodbe materijala za istraživanje. Pretraživanja Google Znalca provedena su pomoću alata Harzing's Publish or Perish (Harzing, 2007).

\section{Portal hrvatskih znanstvenih i stručnih časopisa (HRČAK)}

Baza Portala hrvatskih znanstvenih i stručnih časopisa (HRČAK) posebno je važan izvor podataka. Cilj pretraživanja HRČKA bio je obuhvatiti cjelovitu nacionalnu produkciju u području integrativne bioetike u znanstvenim i stručnim časopisima koja je bila isključena iz pretraživanja Google Scholara, stoga se pretraživanje sastojalo od upita koji će obuhvatiti sve dokumente koji spominju termin integrativna bioetika. Formulacije upita oblikovane su tako da omogućuju obuhvaćanje svih varijanti oblika riječi.

\section{Hrvatska znanstvena bibliografija (CROSBI)}

Podaci Hrvatske znanstvene bibliografije (CROSBI) uvršteni su kao vrsta pregleda i korektiva za sve ostale baze podataka. U ovoj bazi podataka znanstvenici sami unose podatke o svome znanstvenom i stručnom radu i stoga je ona, za hrvatski kontekst, izrazito važan izvor podataka o nacionalnoj bioetičkoj produkciji. Ipak, važno je napomenuti, da tehničke mogućnosti pretraživanja CROSBI baze nisu dovoljno razvijene da bi se postavljeni upiti mogli dovesti na razinu kompleksnosti koja je moguća u drugim bazama. Zbog toga što ne postoje funkcionalnosti operatora povezivanja, diskriminiranja i skraćivanja termina, baza CROSBI pretraživana je se s obzirom na temeljne varijante oblika riječi integrativna bioetika prema padežima hrvatskoga jezika, kao i termin integrative bioethics na engleskom jeziku i termin integrative bioethik na njemačkom jeziku. 


\section{Jezici}

Integrativna bioetika projekt je koji je posebno rasprostranjen u području središnje (Austrija, Njemačka) i jugoistočne Europe (primarno Hrvatska, Srbija, Bosna i Hercegovina, ali i Bugarska, Grčka i Rumunjska). U fazu analize sadržaja uključeni su samo radovi na engleskom i hrvatskom ${ }^{41}$ jeziku zbog jezičnih kompetencija istraživača, no u fazi pripreme materijala pretraživano je i njemačko govorno područje kako bi se stekao uvid u razmjer isključivanja obuhvaćenih izvora prema jezičnom kriteriju. Doprinosi njemačkih, ali i drugih inozemnih autora (izuzev onih koji pišu na engleskom jeziku) koji djeluju u području integrativne bioetike ostaju neriješen istraživački zadatak u kontekstu organizacije znanja za područje integrativne bioetike, no svi članci na stranim jezicima koji spominju pretraživani termin uključeni su u bibliometrijski dio analize područja.

Točan broj rezultata za pojedinačne upite s obzirom na bazu podataka i jezik vidljiv je $u$ Tabeli 4. Podaci iz različitih baza podataka bili su obrađivani tijekom 2019. godine $u$ programu MS Excel na Microsoft 365 Enterprise platformi. Ukupan broj redaka izvora u objedinjenoj Excel tablici iznosio je 2093 retka pri čemu se svaki redak odnosio na jedan preuzeti izvor iz pojedine od baza podataka.

\footnotetext{
${ }^{41} \mathrm{~S}$ obzirom na to da se riječ integrativna bioetika deklinira gotovo identično u susjednim zemljama srodnih jezika pod hrvatskim jezikom podrazumijevaju se i varijante na slovenskom, srpskom i bošnjačkom jeziku. Varijante dativa, lokativa i instrumentala slovenskog jezika nisu vratile niti jedan rezultat u pretraživanim bazama pa se smatra da su svi relevantni izvori obuhvaćeni ovim istraživanjem.
} 
Tabela 4. Broj rezultata za pojedinačne upite s obzirom na bazu podataka i jezik (kolovoz 2018.)

\begin{tabular}{|c|c|c|}
\hline Jezik & Oblikovanje upita & $\mathbf{N}$ \\
\hline \multicolumn{3}{|c|}{ SCOPUS } \\
\hline Engl. & ALL $(*$ integrativ* PRE/0 *ethic*) & 176 \\
\hline Hrv. & ALL $(*$ integrativn* PRE/0 *etik*) & 42 \\
\hline Njem. & ALL $(*$ integrativ* PRE/0 *ethik*) & 206 \\
\hline \multicolumn{3}{|c|}{ WoS } \\
\hline Engl. & $\begin{array}{l}\text { TS=(*integrativ* NEAR/0 *ethic*) OR TI=(*integrativ* } \\
\text { NEAR/0 *ethic*) OR SU=(integrativ* NEAR/0 bioethic*) }\end{array}$ & 48 \\
\hline Hrv. & $\begin{array}{l}\text { TS=(*integrativn* NEAR/0 *etik*) OR TI=(*integrativn* } \\
\text { NEAR/0 *etik*) OR SU=(integrativn* NEAR/0 bioetik*) }\end{array}$ & 0 \\
\hline Njem. & $\begin{array}{l}\text { TS=(*integrativ* NEAR/0 *ethik*) OR TI=(*integrativ* } \\
\text { NEAR/0 *ethik*) OR SU=(integrativ* NEAR/0 bioethik*) }\end{array}$ & 0 \\
\hline \multicolumn{3}{|c|}{ Google Scholar } \\
\hline Engl. & FULL TEXT: "integrative bioethics" -site:hrcak.srce.hr & 300 \\
\hline Hrv. & FULL TEXT: "integrativna bioetika" -site:hrcak.srce.hr & 300 \\
\hline Njem. & FULL TEXT: "integrative bioethik" -site:hrcak.srce.hr & 69 \\
\hline
\end{tabular}

\begin{tabular}{|c|c|c|}
\hline Jezik & Oblikovanje upita & $\mathbf{N}$ \\
\hline \multicolumn{3}{|c|}{ CROSBI } \\
\hline Engl. & integrative bioethics & 179 \\
\hline Hrv. & integrativna bioetika & 107 \\
\hline Hrv. & integrativne bioetike & 93 \\
\hline Hrv. & integrativnoj bioetici & 3 \\
\hline Hrv. & integrativnu bioetiku & 16 \\
\hline Hrv. & integrativnom bioetikom & 9 \\
\hline Njem. & integrative bioethik & 49 \\
\hline \multicolumn{3}{|c|}{ HRČAK } \\
\hline Engl., hrv., njem. & SVI KRITERIJI: integrativ* i bioet* & 496 \\
\hline
\end{tabular}

\section{Ukupan broj redaka izvora: 2093}

Ukupan broj jedinstvenih izvora: 1380 


\section{Provjera izvora tj. sređivanje dohvaćenih podataka}

Dohvaćene podatke bilo je potrebno urediti. Naime, svi izvori podataka tj. svaka baza podataka pohranjuje različite vrste informacija o pojedinom izvoru dohvaćenom pretraživanjima pa je bilo potrebno odabrati one informacije koje će biti korisne za prikaz razvoja i opis domene znanja koju se istražuje. Te su kategorije informacija tretirane kao varijable u analitičkoj fazi istraživanja u svrhu donošenja što kvalitetnijih zaključaka. Uvrštavanjem dohvaćenih podataka u zajedničku Excel tablicu neizbježno dolazi do dupliranja zapisa pa je objedinjeni skup podataka podvrgnut analizi i uklanjanju duplikata. Nakon uklanjanja duplikata istraživački materijal sveden je na 1380 redak tabele tj. jedinstveni izvor. Ako je lociran prijevod nekog članka, drugi se pronađeni izvor tretirao kao duplikat.

\section{Temeljni kriteriji uključivanja}

Kako bi se osiguralo da se istraživanje bavi isključivo izvorima koji se referiraju specifično na koncept integrativne bioetike kao temeljni kriterij inkluzije uzet je kvantitativni frekvencijski kriterij (freq. $\geq 1$ ) tj. za uključivanje $\mathrm{u}$ istraživački opseg u materijalu se pojam integrativna bioetika morao pojavljivati najmanje jedanput $\mathrm{i}$ to u bilo kojoj varijanti oblika riječi na hrvatskom, engleskom ili njemačkom jeziku. Opravdanje frekvencijskog kriterija leži, s jedne strane, u reproducibilnosti istraživanja i nužnosti osiguranja mogućnosti rekonstrukcije istraživanog opsega literature u budućim istraživanjima, ali i, s druge strane, u izvedivosti samog doktorskog istraživanja.

\section{Priprema istraživačkog materijala za analizu sadržaja}

Dobiveni skup izvora $(\mathrm{N}=1380)$ analiziran je i pripremljen za analizu sadržaja. Istraživanje se ograničava na analizu izvora dostupnih u cjelovitom tekstu te su sve druge vrste izvora isključene. Izvori dostupni u cjelovitom tekstu u istraživačkom materijalu uključuju sve vrste indeksiranih članaka, poglavlja u knjigama, objavljena izlaganja, itsl. (dalje: članci). Odabiru se ove vrste izvora jer one tvore osnovicu zabilježenog znanja i umrežene znanstvene komunikacije neke domene znanja. Analiza cjelovitog sadržaja identificiranih izvora predstavlja najdirektniju i dubinsku metodu uvida u terminologiju nekoga područja, a to je ključno za svrhu konstituiranja domene i organizaciju znanja u pojedinom području. Isključene vrste izvora uključuju: knjige, ocjenske radove, uvodnike, pisma uredniku, bibliografije, biltene, eseje, bilješke in memoriam, kazala, note, programske knjižice, 
recenzije, sadržaje, silabe, vijesti, web stranice, zahvale i životopise. Kategorije knjiga i ocjenskih radova isključuju se primarno zbog kriterija izvedivosti doktorskog istraživanja. Pod kategorijom knjige misli se na: monografije, programske knjižnice, zbornike radova, zbornike sažetaka i druge vrste uredničkih knjiga. To istraživačko ograničenje znatno je umanjeno uključivanjem indeksiranih poglavlja u knjigama u opseg analize ukoliko su bila dostupna u cjelovitom tekstu na hrvatskom ili engleskom jeziku. Tabela 5. Prikazuje raspodjelu izvora prema vrsti.

Tabela 5. Raspodjela izvora u istraživačkom materijalu prema vrsti

\begin{tabular}{lcr} 
Vrsta izvora & $\mathbf{N}$ & $\boldsymbol{\%}$ \\
\hline Članci i poglavlja u knjigama & 687 & $49.78 \%$ \\
Knjige & 75 & $5.43 \%$ \\
Ocjenski radovi & 19 & $1.38 \%$ \\
Ostalo & 599 & $43.41 \%$ \\
\hline Ukupno & $\mathbf{1 3 8 0}$ & $\mathbf{1 0 0 \%}$
\end{tabular}

U idućem koraku pripreme svaki članak provjeren je s obzirom na dostupnost cjelovitog teksta i temeljni frekvencijski kriterij uključivanja. Tabela 6. prikazuje način oblikovanja finalnog seta koji će biti analiziran. Važno je napomenuti da bibliometrijska analiza članaka obuhvaća sve one radove koji u tijelu teksta spominju pojam integrativne bioetike, neovisno o jeziku rada tj. uzorak u tom dijelu analize ne isključuje radove prema kriteriju jezika $(\mathrm{N}=281)$.

Tabela 6. Kriteriji isključivanja izvora u redoslijedu provedenih postupaka

\begin{tabular}{lcr} 
Vrsta izvora & $\mathbf{N}$ & \% \\
\hline Ukupni broj identificiranih izvora & 2093 & $100.00 \%$ \\
Isključivanje duplikata & -713 & $34.07 \%$ \\
Isključivanje po vrsti izvora & -693 & $33.11 \%$ \\
Isključivanje zbog nemogućnosti pristupa članku & -60 & $2.87 \%$ \\
Isključivanje jer članak ne spominje pojam & -346 & $16.53 \%$ \\
\hline Isključivanje po kriteriju jezika članka & -31 & $1.48 \%$ \\
\hline Broj radova uključen u analizu sadržaja & $\mathbf{2 5 0}$ & $\mathbf{1 0 0 \%}$
\end{tabular}




\section{Deskriptivna bibliometrijska analiza}

Bibliometrijska istraživanja različitih karakteristika dokumenata koji čine analitički set ključna su vrsta metodoloških postupaka za obuhvat neke analizirane domene. Bibliometrijska analiza ove disertacije utemeljena je na metodološkim priručnicima Research Methods in Information (2. izd.) Alison Jane Pickard (2013), Measuring Academic Research: How to Undertake a Bibliometric Study Ane Andrés (2009) te već spomenutom djelu Domain Analysis for Knowledge Organization: Tools for Ontology Extraction (2015) Richarda P. Smiraglie.

Namjera je ove studije bibliometrijska konstitucija domene integrativne bioetike, stoga se ova analiza ne usmjerava na evaluativne, već na deskriptivne bibliometrijske postupke. Djela Andrés (2009) i Smiraglie (2015) iskorištena su kako bi se identificiralo ključne bibliometrijske varijable čije vrijednosti ukazuju na razvoj analizirane domene. Prema Andrés (2009, str. 4) ,razmatranjem svih dokumenata objavljenih u određenom području istraživanja moguće je utvrditi kako se distribuiraju prema različitim varijablama.“

Analiza znanstvene produktivnosti utvrdit će za područje integrativne bioetike vremensku i geografsku distribuciju znanstvene produktivnosti članaka, najproduktivnije časopise i autore, produktivnost autora $\mathrm{s}$ obzirom na njihovu afilijaciju s predmetnim područjem iz kojega dolaze i instituciju na kojoj djeluju te vrste doprinosa koje produciraju.

Ključni moment bibliometrijske analize bit će provjera obrazaca produktivnosti autora i časopisa u području integrativne bioetike koji će biti provjereni prema Lotkinom i Bradfordovom zakonu pri čemu null hipoteza označava da ne postoji statistički značajna povezanost između obrazaca znanstvene produktivnosti autora $\left(H_{0 a}\right)$, odnosno časopisa $\left(H_{0 b}\right)$ $\mathrm{u}$ području integrativne bioetike $\mathrm{s}$ očekivanim obrascima prema referentnom zakonu. Bibliometrijska analiza provedena je pomoću softvera MS Excel na Microsoft 365 Enterprise platformi. 


\section{Analiza sadržaja i fasetna analiza literature u području integrativne bioetike}

Konstrukciju osnove za izgradnju sustava za organizaciji znanja u području integrativne bioetika ova disertacija utemeljuje u analizi sadržaja. Analiza sadržaja za organizaciju znanja poznaje tekovine socioloških i sociolingvističkih pristupa tom metodološkom postupku, no samu metodu nužno je proširiti spoznajama područja klasifikacije. Naime, kada se analizu sadržaja želi upregnuti za ostvarenje vrlo konkretne praktične svrhe, primjerice bibliografskih klasifikacija tada postupak analize sadržaja mora osigurati otkrivanje onih dimenzija analizirane tematike koja će omogućiti osiguranje predmetnog pristupa $\mathrm{u}$ istraživanom području. U ovoj disertaciji, kao što je prethodno najavljeno smatra se nužnim sustav za organizaciju znanja $u$ području integrativne bioetike utemeljiti u postavkama interdisciplinarne i transdisciplinarne organizacije znanja. Stoga, metodološko rješenje za analizu sadržaja bit će znatno informirano metodološkim aspektima djela Interdisciplinarna organizacija znanja Ricka Szostaka, Claudia Gnolia i Marie Lopez Huertas iz 2016. godine. Značajno polazište analize sadržaja bit će i članci Claudia Gnolija tj. članak Klasificiranje fenomena kojeg je Gnoli objavio u četiri djela, a koji se odnose na različite aspekte toga klasifikacijskog postupka: 1. Dimenzije (Gnoli, 2016), 2. Tipovi i razine (Gnoli, 2017a), 3. Fasete (Gnoli, 2017b) i 4. Teme i reme (Gnoli, 2018).

Prema Poliju (kod Smiraglia, 2015) domene znanja trebalo bi analizirati s obzirom na razine stvarnosti kojima se bave jer smatra da će zbog logike njihove organizacije biti potrebno podržati različite načine otkrivanja znanja na pojedinoj razini.

Pripremljeni analitički set članaka iz područja integrativne bioetike analizirat će se induktivnim i deduktivnim pristupom pomoću softvera za kvalitativnu analizu podataka MaxQDA Analytics Pro 2020.

Razina granularnosti obaju vrsta analiza bit će dokument sam. Ta odluka temeljena je na pristupu Claudia Gnolija koji objašnjava dimenzije organizacije znanja koje mogu biti obuhvaćene jednim sustavom za organizaciju znanja. Tako će cilj ove analize biti razotkriti međuodnose fenomena (dimenzija $\beta$ ), perspektiva (dimenzija $\gamma$ ) i dokumenata (dimenzija $\delta$ ). Dimenzija $\zeta$ koja se odnosi na informacijske potrebe objašnjena je u teorijskom dijelu rada, dok će se dimenzija $\eta$ tj. dimenziju zajednica koje sudjeluju u oblikovanju interakcije prethodnih razina razotkriti bibliometrijskom analizom. 
U sklopu induktivne i deduktivne analize identificirat će se fenomeni o kojima dokumenti govore te perspektive tj. epistemološka stajališta $\mathrm{s}$ kojih se fenomene razmatra. Time će se identificirati teme sadržane u pojedinom dokumentu sukladno opisu klasifikacijskog postupka koji predlaže Claudio Gnoli.

U induktivnom djelu analize istraživanje će se temeljiti na klasičnim postupcima analize sadržaja koja će uključivati kodiranje tematike i iscrpno bilježenje uočenih fenomena $\mathrm{i}$ perspektiva. Kategorija tema sastojat će se od slobodnih kodova koji će pokazivati i odnos u kojem su fenomeni i perspektive bili uočeni. Primjerice, dokument može biti o pobačaju iz feminističke perspektive koji se komentira s pozicije pluriperspektivizma. U tom slučaju kodirat će se riječ pobačaj u kategoriji fenomena, riječi feminizam i pluriperspektivizam u kategoriji perspektiva i izraz pobačaj iz feminističke perspektive komentiran s pozicije pluriperspektivizma bit će određen kao tema djela.

Takvo rječito i slobodno kodiranje, u drugoj, deduktivnoj fazi analize sadržaja usustavit će se fasetnom analizom prema strukturi Klasifikacije integrativnih razina. U ovoj fazi svaki će se iskaz teme, pojedinačni sudjelujući fenomen i perspektiva prevesti na notaciju Klasifikacije integrativnih razina prema sintaktičkim pravilima za konstrukciju notacije. U ovoj fazi razotkrit će se svi induktivno definirani kodovi koji nisu izrazivi klasama Klasifikacije integrativnih razina. Ukoliko pojedini fenomen ili perspektiva neće biti izrazivi njihov će se kod duplirati u zasebni set kodova koji će sadržavati neizrazive fenomene tj. neizrazive perspektive u klasifikaciji integrativnih razina. Tako će se direktno bilježiti tematske specifičnosti područja integrativne bioetike u odnosu na trenutni stadij razvoja Klasifikacije integrativnih razina.

Rezultati analize tvorit će osnovicu za izgradnju sustava za organizaciju znanja tj. specijalne klasifikacije za osiguranje predmetnog pristupa u integrativnoj bioetici, razvoj klasifikacije integrativnih razina i kao osnova za kritičko razmatranje postojećih predmetnih sustava u području bioetike.

Szostak (2015) navodi kako u ovoj fazi istraživanja područja nema smisla istraživati konzistenciju indeksiranja među indekserima jer korisne klasifikacije perspektiva još nisu u potpunosti uspostavljene, stoga taj postupak nije proveden. 


\section{Ograničenja istraživačkog pristupa}

Prije iznošenja rezultata istraživanja potrebno je objasniti i ograničenja istraživačkog postupka. Na razini uzorkovanja ovo istraživanje analizira pretežito časopisnu produkciju analiziranog područja što znači da analiza knjižne produkcije ostaje otvoreni istraživački zadatak budućih istraživanja. Nadalje, zbog nedostupnosti kvalitetnih citatnih metapodataka područje nije bilo moguće istražiti na razini citacijskih praksi te je i ta vrsta istraživanja veliki istraživački pothvat s kojim bi se, upravo zbog osiguranja predmetnog pristupa, trebalo suočiti u budućim istraživanjima koja će domenu konstituirati na temelju obrazaca citiranja. Integrativna bioetika jedna je od razvojnih faza bioetike, što znači da je za kompletnije osiguranje predmetnog pristupa u području potrebno obujmiti i cijelu domenu bioetike. Naravno, takav pothvat zahtijevao bi sasvim drugačiju dimenziju istraživanja kao i drugačije, terminološki zasnovane istraživačke metode iz tradicije automatskih pristupa organizaciji znanja ponajprije zbog količine postojeće literature i varijabilnosti dostupnih bibliografskih podataka što u ovom istraživanju nije bilo poduzeto zbog kriterija izvedivosti doktorskog istraživanja. Iako prema Szostaku i suradnicima (2016) ne postoji razlika u načinima osiguranja predmetnog pristupa dokumentima prema perspektivama u interdisciplinarnom i transdisciplinarnom kontekstu na razini same vrste uključenih materijala ovo se doktorsko istraživanje usmjerava na transdisciplinarnost koju aktivira akademski milje, dok transdisciplinarnost koju pokreću građanske inicijative na razini neakademskih izvora znanja tek treba obujmiti. To je istraživačko ograničenje svjesno poduzeto kako bi se analizom domene integrativne bioetike prvotno izgradila kompetencija kandidata da analizira neakademske izvore o bioetičkim pitanjima uvrštenima u zbirke koje građu okupljaju prvenstveno $\mathrm{u}$ kontekstu pluriperspektivizma kao specifičnog nazora generiranog $u$ diskurzivnom kontekstu integrativne bioetike. Bez analize domene integrativne bioetike ne bi bilo moguće ostvariti zadaće organizacije znanja u zbirkama neakademskih izvora bioetičkih institucija u RH. Buduća istraživanja mogla bi se usmjeriti na tretman pojedinačnih bioetički relevantnih fenomena $\mathrm{u}$ neakademskim izvorima i identifikaciju aspekata koji ih karakteriziraju u kontekstu pluriperspektivno zasnovane organizacije znanja i zbirki dokumenata. 


\section{REZULTATI DOKTORSKOG ISTRAŽIVANJA}

Poglavlje donosi rezultate doktorskog istraživanja. Prikazani su rezultati deskriptivne bibliometrijske analize u odnosu na vremensku distribuciju produkcije članaka u području integrativne bioetike, vrste izvora $u$ analiziranom setu, obrasce produktivnosti autora, afilijacije autora, geografsko podrijetlo autora, obrasce produktivnosti časopisa, obrasce produktivnosti članaka prema jeziku priloga i prema njihovoj formalnoj kategorizaciji.

Na kraju poglavlja objašnjeni su glavni zaključci provedene analize sadržaja i radovi prezentirani prema glavnim klasama fenomena kojima su pridruženi, dok se o samim rezultatima analize sadržaja detaljno raspravlja u diskusijskom dijelu rada. 


\section{Deskriptivna bibliometrijska analiza}

U ovome poglavlju rezultati bibliometrijske analize prikazani su prema enumeriranim vrstama postupaka koji se opisuju u pojašnjenju metodologije doktorskog rada. Za svaki element analize prikazuje se broj članaka uključen u analizu i odgovarajući grafički ili tablični prikaz rezultata. Namjera ovog poglavlja izvještaj je o rezultatima dok se njihovo značenje u načelu komentira kasnije, u diskusijskom dijelu rada.

\section{Vremenska distribucija produkcije članaka u području integrativne bioetike}

Analizom vremenske distribucije produkcije članaka u području integrativne bioetike utvrđen je relativno stabilan obrazac produkcije pri čemu je potrebno uočiti izraziti porast produkcije 2012. i 2014. godine u domaćem i međunarodnom kontekstu uslijed rasprave o ishodištima integrativističkih pristupa u bioetici i otkrića Fritza Jahra i njegova koncepta bioetičkog imperativa. Srednja aritmetička vrijednost $(M)$ broja članaka po godini iznosi 20.1 članaka $(M d n=22.5)$.

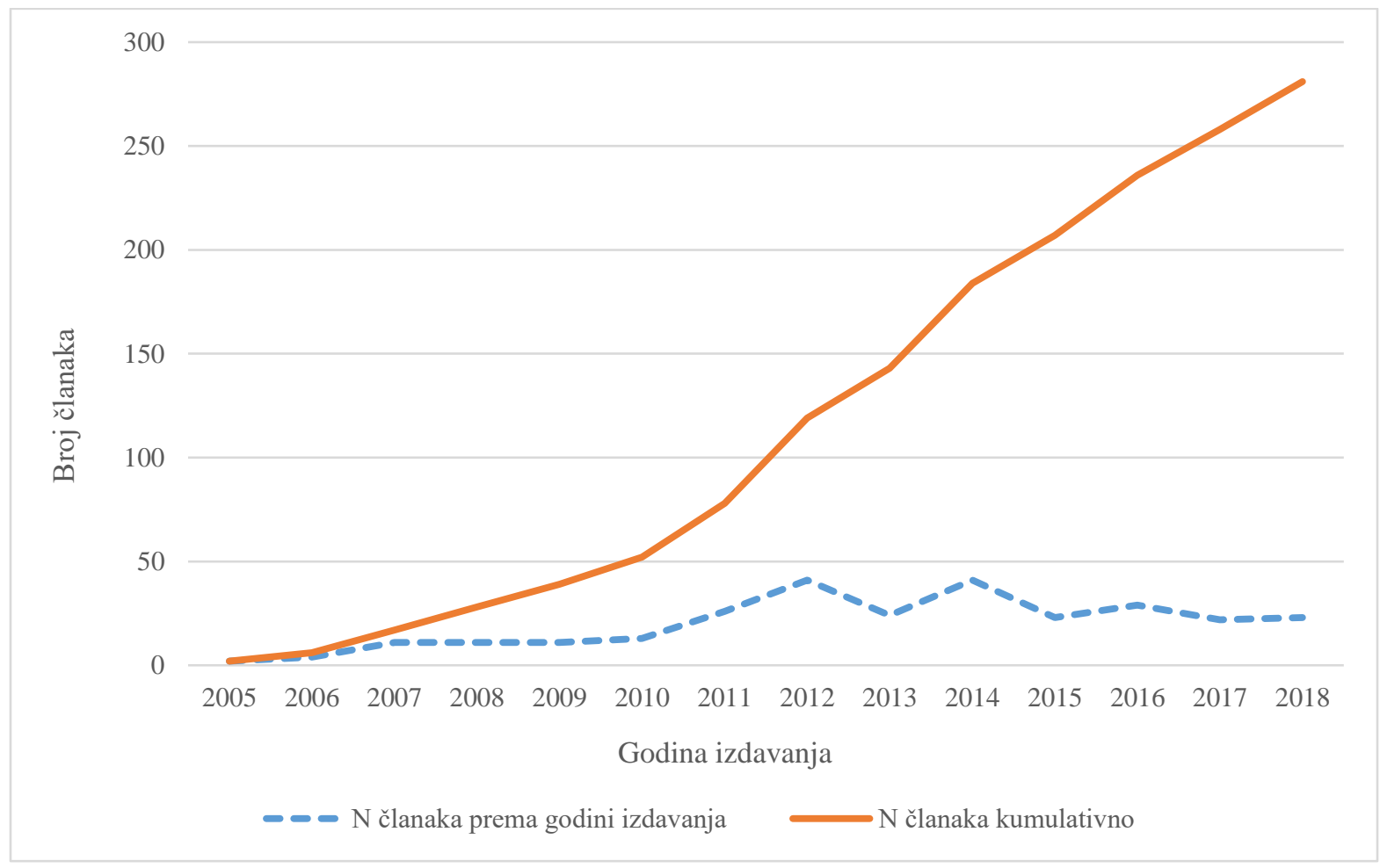

Slika 7. Vremenska distribucija produkcije članaka u području integrativne bioetike

\section{Vrste izvora u analiziranom setu}

Konstituirani uzorak pretežito čine članci u časopisima, dok su poglavlja u knjigama zastupljena u manjem dijelu zbog načina uzorkovanja. Pojedini analitički postupci uključuju 
obje vrste izvora, dok metodološke zakonitosti analiza poput primjene Bradfordovog zakona traže da se postupci usmjere samo na časopisnu produkciju. Te zakonitosti poštivane su u ovdje izloženoj analizi područja integrativne bioetike.

Tabela 7. Zastupljene vrste izvora u analiziranom setu

Vrsta izvora

$\mathrm{N}$ radova

$\%$

Članak

246

$88 \%$

Poglavlje u knjizi

35

$12 \%$

Total

281

$100 \%$

Kada govorimo o vrsti izvora u analiziranom setu potrebno je napomenuti da se uzorak sastoji od priloga koji termin integrativne bioetike spominju primarno u tijelu rada, no značajan postotak radova termin spominje samo u referencama. Ovi podaci pokazuju na relativno visoku referencijalnost $u$ području odnosno na to da integrativna bioetika često nije središnja tema priloga već da se na koncept i njegove zasade autori referiraju i u raznolikim, području srodnim, kontekstima. Ti će konteksti biti razotkriveni u analizi sadržaja priloga.

Tabela 8. Analiza izvora prema mjestu pojavljivanja istraživanog termina

Mjesto pojavljivanja termina

Pojavljivanje u tekstu

Pojavljivanje u referencama

Total
$\mathbf{N}$

196

85

281
$69.75 \%$

$30.25 \%$

$100 \%$ 


\section{Obrasci produktivnosti autora}

Autorska produkcija u području integrativne bioetike utvrđena je na temelju nekoliko parametara. Utvrđeni su najproduktivniji autori, obrasci produktivnosti s obzirom na Lotkin zakon i obrasci koautorstva.

Kada govorimo o najproduktivnijim autorima u području posebno se ističe koautorski rad Amira Muzura i Ive Rinčić s Medicinskog fakulteta Sveučilišta u Rijeci čiji rad obuhvaća 10.72\% ukupne autorske produktivnosti područja. Ukupno je identificirano 221 individualna autora koji pišu samostalne ili koautorske priloge. Za nešto manje od $40 \%$ produktivnosti u području integrativne bioetike zaslužno je svega 19 autora ( $\mathrm{N}$ priloga > 5).

Tabela 9. Najproduktivniji autori u području integrativne bioetike (N autorstava > 5)

Ime i prezime autora

N autorstava

Muzur, Amir 20

$4.77 \%$

Rinčić Lerga, Iva 20

$4.77 \%$

Radenović, Sandra 13

$3.10 \%$

Jurić, Hrvoje 10

$2.39 \%$

Čović, Ante 10

$2.39 \%$

Sass, Hans-Martin 9

$2.15 \%$

Sodeke, Stephen O. 8

$1.91 \%$

Tomašević, Luka 7

$1.91 \%$

Zagorac, Ivana 7

$1.67 \%$

Cifrić, Ivan $1.43 \%$

Kaluđerović, Željko $1.43 \%$

Marinčić, Mile 6

$1.43 \%$

Pessini, Leo

$1.43 \%$

Donev, Dejan

$1.19 \%$

Gosić, Nada $1.19 \%$

Krznar, Tomislav $1.19 \%$

Mladina, Nada $1.19 \%$

Sorta-Bilajac Turina, Iva $1.19 \%$

Turza, Karel $1.19 \%$

Ostali autori 260 $62.05 \%$

Total 419 $100 \%$ 
Utvrđeni su i obrasci koautorstva pri čemu je zamjetljivo da se prilozi u području integrativne bioetike pretežito objavljuju kao samostalna autorstva te se ta činjenica može objasniti time da autori koji pišu priloge pretežito dolaze iz područja filozofije ili filozofiji bliskim disciplinama.

Tabela 10. Usporedba samostalnih autorstava i koautorstava

Vrsta autorstva

Samostalno autorstvo

Koautorstvo

Total

Produktivnost autora možemo podijeliti i u tri relativno podjednaka bloka koja se odnose na autore koji vrlo rijetko objavljuju u području, autore koji povremeno objavljuju u području i redovite produktivne autore područja. Na grafikonu ispod vidljivo je da broj autora opada $\mathrm{s}$ obzirom na broj objavljenih radova.

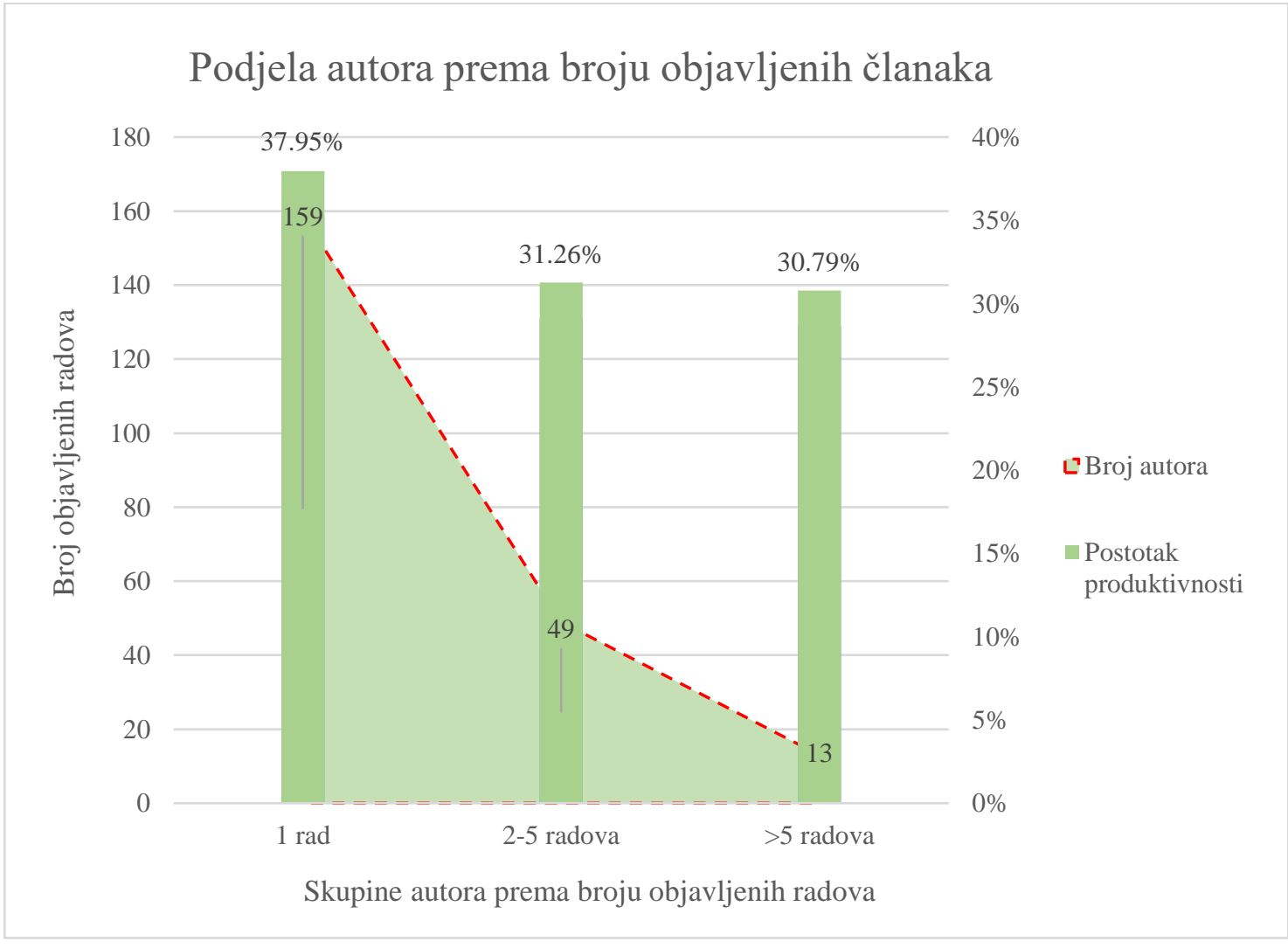

Slika 8. Podjela autora prema broju objavljenih članaka 
Kako bismo provjerili je li ovakva distribucija produkcije članaka očekivana istražena je primjenjivost Lotkina zakona pomoću radova Andres (2009), Kumar i Senthilkumar (2019), Chaturbhuj i Sadik Batch (2020) te Roselin Jahina, Sadik Batcha i Ahmad (2020). Primjena Lotkina zakona izvan područja fizike i kemije u kojima je nastala dovođena je više puta $u$ pitanje, no prema nekim autorima poput Murphyija (1973) i Suresh Kumara (2017) primjena Lotkina zakona moguća je i poželjna i u humanističkim i društvenim znanostima. Lotkin zakon uspostavlja opće pravilo i obrazac znanstvene produktivnosti koji bi trebao vrijediti za sva područja znanosti (Pao, 1985). Nije moguće procijeniti je li ova vrsta analize do sada primjenjivana na područje bioetike jer provedena pretraživanja baza podataka nisu vratila niti jedan relevantan prilog, stoga je važno utvrditi odudaraju li obrasci produkcije od općeg pravila kako ga je definirao Lotka. Prema tome zakonu postoji inverzni odnos između broja autora koji produciraju određeni broj radova i broja produciranih radova po autoru. Prema Pao (ibid., str. 305) „Lotkin zakon tvrdi da je broj autora $y_{x}$ kojima pripada neki x radova obrnuto proporcionalan X koji označava produktivnost svakog pojedinačnog autora. Taj se odnos izražava kao:

$$
X_{n} * y^{x}=c \text { ". }
$$

Spomenute aplikacije Lotkina zakona kontrastiraju opažene frekvencije s očekivanima te su razlike provjerene hi-kvadrat testom. Ista metodologija slijedi se i u ovom doktorskom radu.

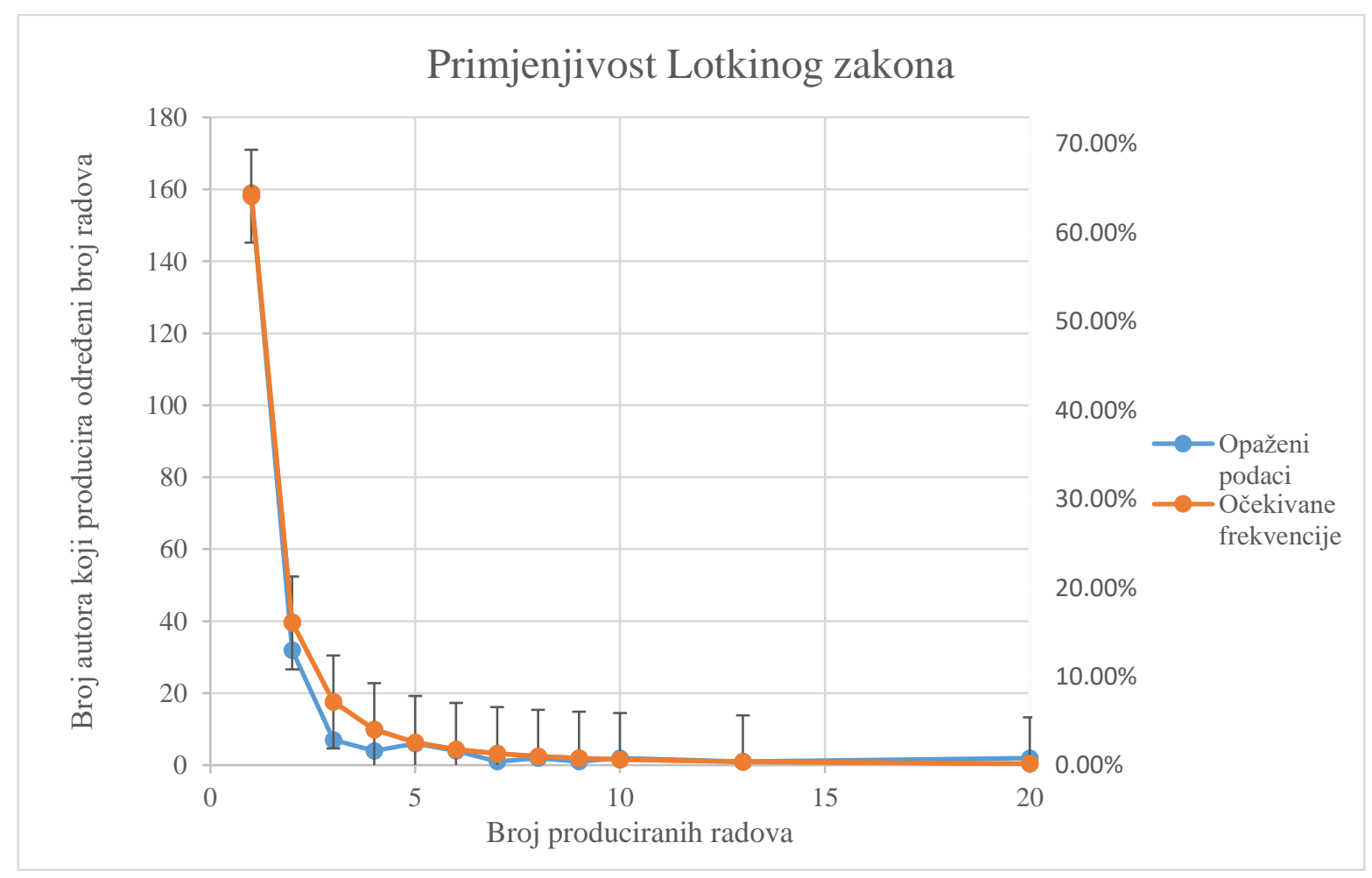

Slika 9. Primjenjivost Loktinog zakona na produktivnost autora u području integrativne bioetike 
Na Slici 9. prezentirana su odstupanja opaženih frekvencija broja radova koje produciraju autori u području integrativne bioetike od očekivanih frekvencija zadanih Lotkinim zakonom za isti $\mathrm{N}$ radova. Grafikon prikazuje da najproduktivniji autori produciraju nešto više radova od onoga što je očekivana frekvencija u znanosti općenito. Na drugom kraju grafa zamjetljiv je visok broj radova autora koji u području integrativne bioetike participiraju samo s jednim radom. Ovo zapažanje može se nadopuniti i opservacijom da se manji broj autora od očekivanoga odvažuje publicirati dva ili tri rada u području integrativne bioetike. Broj autora koji objavljuju 4 ili više radova sukladan je očekivanim frekvencijama. Poklapanje podataka o produktivnosti autora s Lotkinim modelom znanstvene produkcije tj. razlike između opaženih i očekivanih frekvencija provjerene su hi-kvadrat testom $\chi^{2}(11, \mathrm{~N}=221)=20.3, p<.05$. Možemo reći da nema značajne razlike između modela i opaženih podataka tj. $H_{0 a}$ je odbačena jer postoji statistički značajna povezanost između obrazaca znanstvene produktivnosti autora $\mathrm{u}$ području integrativne bioetike $\mathrm{s}$ očekivanim obrascima prema Lotkinom zakonu. Rezultati ove analize pokazuju primjerenost odabranog uzorka da reprezentira neko područje znanja i time čini dobru osnovicu za daljnje istraživačke postupke nad definiranim setom dokumenata. Izračun dostupan u Prilogu 3. 


\section{Afilijacije autora}

U analiziranom setu dokumenata utvrđeno je 345 pojedinačnih instanci afilijacija pri čemu se jedna afilijacija brojala samo jednom po dokumentu. Ukupno je identificirano 108 jedinstvenih institucija s kojima su autori afilijirani.

Tabela 11. Afilijacije autora analiziranih priloga ( $N$ afilijacija $>4)$

\begin{tabular}{lcr} 
Naziv afilijacije & N & \% \\
\hline Sveučilište u Zagrebu & 73 & $21.16 \%$ \\
Sveučilište u Rijeci & 46 & $13.33 \%$ \\
Sveučilište u Beogradu & 18 & $5.22 \%$ \\
Sveučilište u Splitu & 17 & $4.93 \%$ \\
Ruhrsko Sveučilište u Bochumu & 11 & $3.19 \%$ \\
Sveučilište u Novom Sadu & 11 & $3.19 \%$ \\
Sveučilište u Georgetownu & 10 & $2.90 \%$ \\
Sveučilište u Tuskegeeju & 9 & $2.61 \%$ \\
Sveučilište u Sarajevu & 9 & $2.61 \%$ \\
Sveučilište u Tuzli & 7 & $2.03 \%$ \\
Sveučilište Josipa Jurja Strossmayera u & 6 & $1.74 \%$ \\
Osijeku & 5 & $1.45 \%$ \\
Sveučilišni centar São Camilo & 5 & $1.45 \%$ \\
Srednja škola "Ivan Švear" Ivanić Grad & 5 & $1.16 \%$ \\
Sveučilište "St. Cyril and Methodius" & 4 & $1.16 \%$ \\
Sveučilište u Ljubljani & $\mathbf{1 0 8}$ & $31.88 \%$ \\
Ostale afilijacije & & $\mathbf{1 0 0 \%}$
\end{tabular}

Tablični prikaz odnosa domaćih i inozemni znanstvenih institucija pokazuje da su u području integrativne bioetike autori najčešće afilijirani s inozemnim institucijama (67.59\%), no autori iz Republike Hrvatske objavljuju najviše radova. Autori sa inozemnih institucija objavljuju $46.96 \%$ radova u području integrativne bioetike. Ovi podaci kongruentni su s prethodno izloženim podacima o autorima i njihovoj produktivnosti tj. da se dugi rep Slike 9. odnosi na autore poput Muzura, Rinčić, Čovića i Jurića koji su afilijirani s institucijama iz Republike Hrvatske, te Sassa i Sodekea kao inozemno afilijirane autore. 
Tabela 12. Afilijacije s domaćim i inozemnim institucijama

\begin{tabular}{lrrrrr}
$\begin{array}{l}\text { Porijeklo afilijacija } \\
\text { autora }\end{array}$ & $\begin{array}{r}\mathbf{N}_{\mathbf{a}} \mathbf{j e d i n s t v e n i h} \\
\mathbf{a f i l i j a c i j a}\end{array}$ & $\mathbf{N}_{\mathbf{b}}$ afilijiranih radova & $\mathbf{\%} \mathbf{N}_{\mathbf{a}}$ & $\mathbf{\%} \mathbf{N}_{\mathbf{b}}$ \\
\hline $\begin{array}{l}\text { Afilijacije iz RH } \\
\text { Inozemne afilijacije u }\end{array}$ & 35 & 183 & $32.41 \%$ & $53.04 \%$ \\
$\begin{array}{l}\text { JI Europi } \\
\text { Inozemne afilijacije u } \\
\text { ostatku svijeta }\end{array}$ & 18 & 65 & $16.67 \%$ & $18.84 \%$ \\
\hline Total & 55 & 97 & $50.93 \%$ & $28.12 \%$ \\
& $\mathbf{1 0 8}$ & $\mathbf{3 4 5}$ & $\mathbf{1 0 0 \%}$ & $\mathbf{1 0 0 \%}$
\end{tabular}




\section{Geografsko porijeklo autora}

Autori zastupljeni u analiziranom setu dokumenata dolaze iz 26 različitih zemalja diljem svijeta pri čemu se nešto više od $50 \%$ produkcije može pripisati hrvatskima autorima u skladu sa svim prethodno izloženim rezultatima.

Tabela 13. Obrasci znanstvene produktivnosti prema zemlji publiciranja radova

\begin{tabular}{|c|c|c|}
\hline Zemlja & $\mathbf{N}$ & $\%$ \\
\hline Hrvatska & 158 & $53.92 \%$ \\
\hline Srbija & 34 & $11.60 \%$ \\
\hline Njemačka & 20 & $6.83 \%$ \\
\hline Sjedinjene Američke Države & 20 & $6.83 \%$ \\
\hline Bosna i Hercegovina & 15 & $5.12 \%$ \\
\hline Brazil & 9 & $3.07 \%$ \\
\hline Sjeverna Makedonija & 6 & $2.05 \%$ \\
\hline Ukrajina & 3 & $1.02 \%$ \\
\hline Ujedinjeno Kraljevstvo & 3 & $1.02 \%$ \\
\hline Mađarska & 3 & $1.02 \%$ \\
\hline Indija & 2 & $0.68 \%$ \\
\hline Nizozemska & 2 & $0.68 \%$ \\
\hline Austrija & 2 & $0.68 \%$ \\
\hline Slovenija & 2 & $0.68 \%$ \\
\hline Bugarska & 2 & $0.68 \%$ \\
\hline Kolumbija & 2 & $0.68 \%$ \\
\hline Kanada & 1 & $0.34 \%$ \\
\hline Portugal & 1 & $0.34 \%$ \\
\hline Danska & 1 & $0.34 \%$ \\
\hline Argentina & 1 & $0.34 \%$ \\
\hline Čile & 1 & $0.34 \%$ \\
\hline Italija & 1 & $0.34 \%$ \\
\hline Grčka & 1 & $0.34 \%$ \\
\hline Turska & 1 & $0.34 \%$ \\
\hline Australija & 1 & $0.34 \%$ \\
\hline Kamerun & 1 & $0.34 \%$ \\
\hline Total & 293 & $100 \%$ \\
\hline
\end{tabular}


Analiziramo li dinamiku produkcije u području s obzirom na matične kontinente autora koji pišu prilog u području možemo zaključiti da je integrativna bioetika europski situirana znanstvena zajednica, no do se njen utjecaj proteže i na gotovo sve naseljene kontinente o čemu bolje svjedoče grafički prikazi u nastavku.

Tabela 14. Obrasci znanstvene produktivnosti prema kontinentu

\begin{tabular}{lrr} 
Kontinent & N radova & \% \\
\hline Europa & 255 & $87.03 \%$ \\
Sjeverna Amerika & 21 & $7.17 \%$ \\
Južna Amerika & 13 & $4.44 \%$ \\
Azija & 2 & $0.68 \%$ \\
Afrika & 1 & $0.34 \%$ \\
Australija & 1 & $0.34 \%$ \\
\hline Total & $\mathbf{2 9 3}$ & $\mathbf{0 \%}$
\end{tabular}




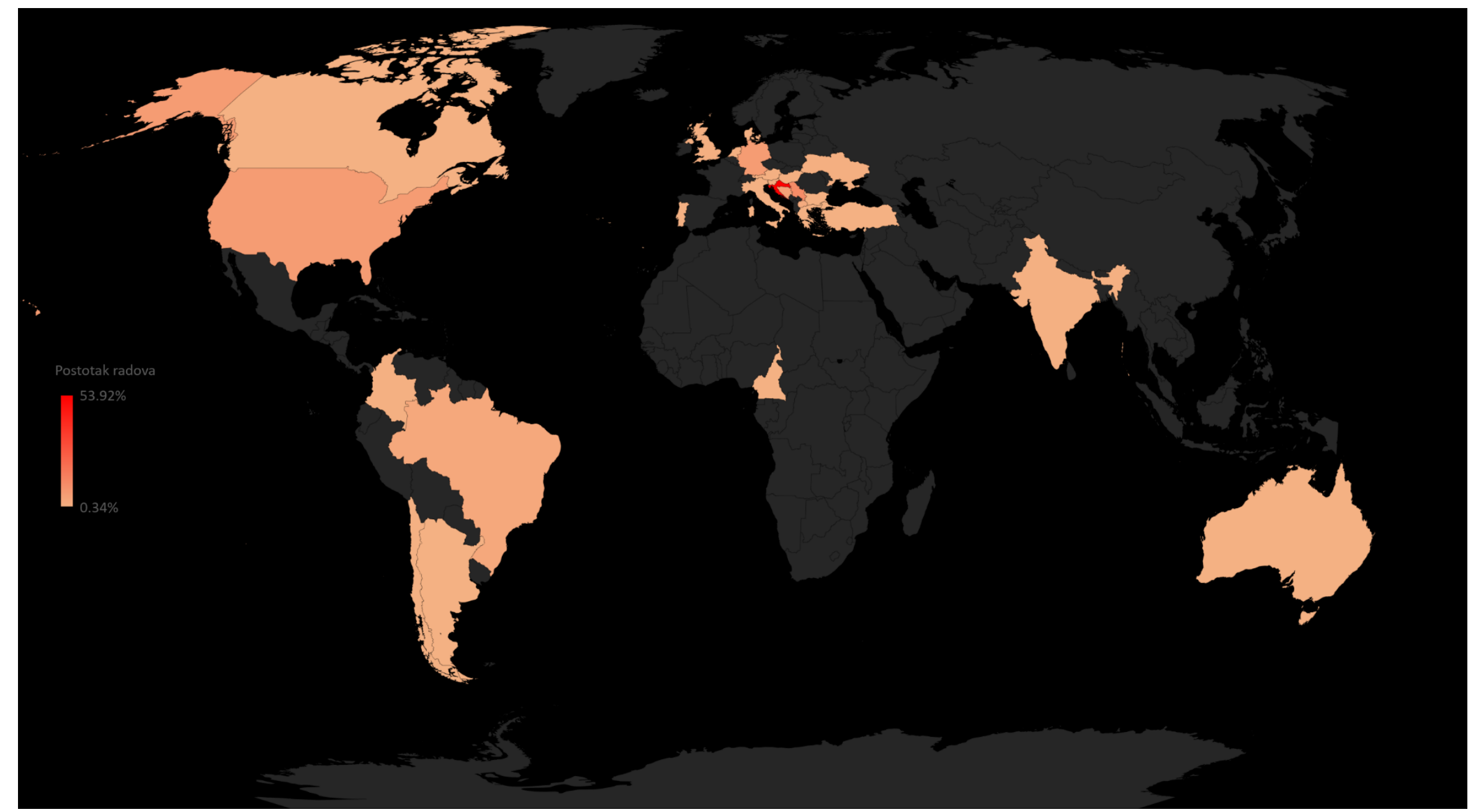

Slika 10. Geografska distribucija znanstvene produkcije autora u području integrativne bioetike (Svijet) $)^{42}$

${ }^{42}$ Grafički prikaz stvoren je pomoću Microsoft Excel softvera kombiniranjem izvornih istraživačkih podataka i javno dostupnih statističkih podataka. Powered by Bing $\odot$ Australian Bureau of Statistics, GeoNames, Microsoft, Navinfo, TomTom, Wikipedia. 


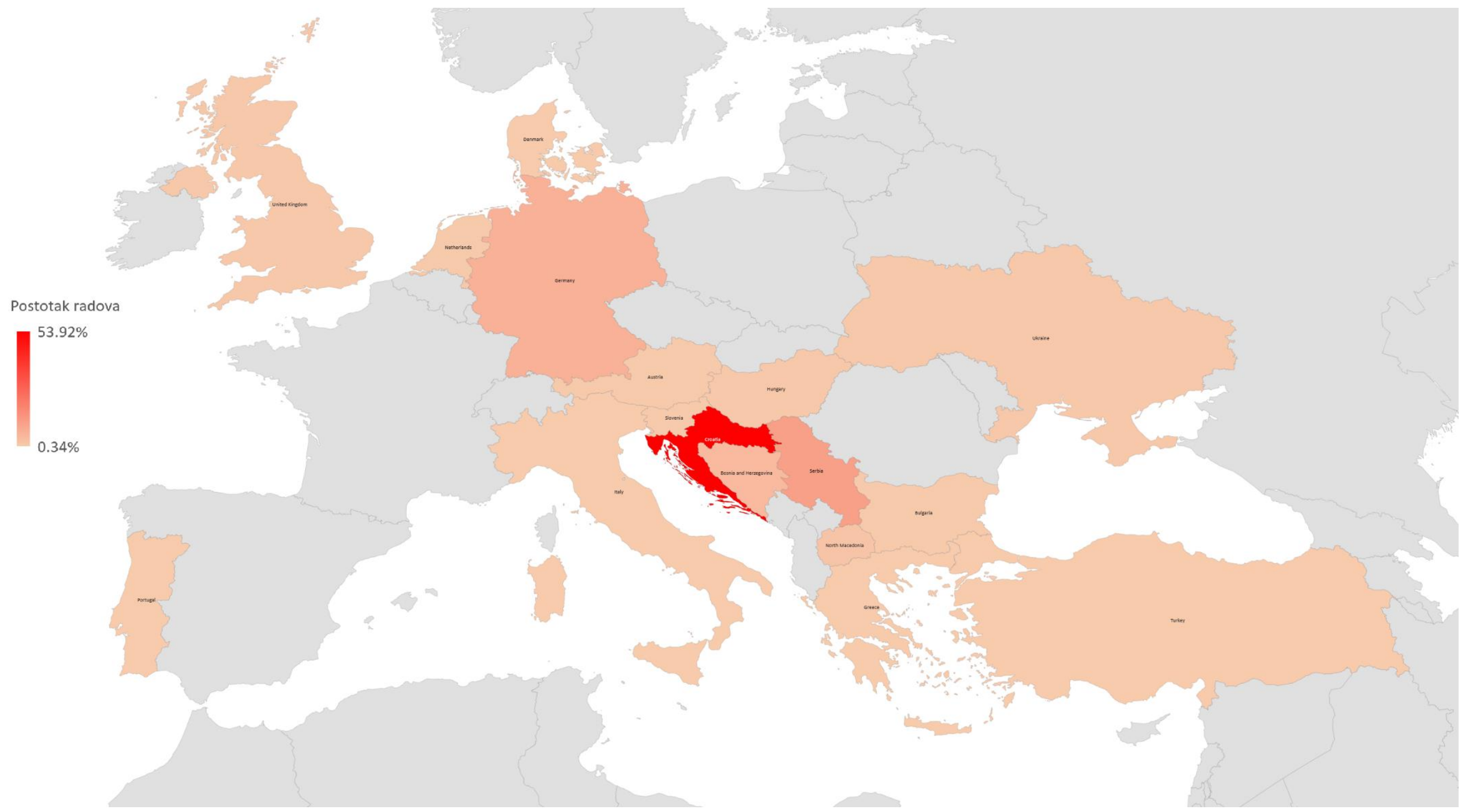

Slika 11. Geografska distribucija znanstvene produkcije autora u području integrativne bioetike (Europa) ${ }^{43}$

${ }^{43}$ Grafički prikaz stvoren je pomoću Microsoft Excel softvera kombiniranjem izvornih istraživačkih podataka i javno dostupnih statističkih podataka. Powered by Bing $\odot$ Australian Bureau of Statistics, GeoNames, Microsoft, Navinfo, TomTom, Wikipedia. 


\section{Obrasci produktivnosti časopisa}

Članci se najstabilnije objavljuju u domaćim časopisima na hrvatskom ili engleskom jeziku od kojih neki imaju i međunarodna uredništva. Tabela u nastavku donosi popis najvažnijih časopisa u kojima autori objavljuju svoje priloge, dok je popis naslova knjiga u kojima su objavljena uključena indeksirana poglavlja dostupan kao Prilog 2 na kraju doktorskog rada. Kako bi se utvrdilo ponaša li se časopisna produkcija u području integrativne bioetike $u$ skladu s bibliometrijskim zakonima istražena je primjenjivost Bradfordovog zakona.

\section{Tabela 15. Matične publikacije radova (časopisi)}

Naziv časopisa

Jahr : europski časopis za bioetiku

Filozofska istraživanja

Synthesis Philosophica

Socijalna ekologija

Znakovi vremena

Nova prisutnost

American Journal of Bioethics

ARHE

Journal international de bioéthique et d'éthique des sciences

Crkva u svijetu

Metodički ogledi

Revista Bioética

Facta Univesitatis

Medicine, Health Care and Philosophy

Acta Clinica Croatica

Bioethics

Croatian Medical Journal

Developing World Bioethics

Ostali časopisi

\begin{tabular}{crr}
$\mathbf{N}$ & $\%$ \\
\hline 52 & $21.14 \%$ \\
30 & $12.20 \%$ \\
15 & $6.10 \%$ \\
11 & $4.47 \%$ \\
11 & $4.47 \%$ \\
7 & $2.85 \%$ \\
5 & $2.03 \%$ \\
5 & $2.03 \%$ \\
5 & $2.03 \%$ \\
4 & $1.63 \%$ \\
4 & $1.63 \%$ \\
4 & $1.63 \%$ \\
3 & $1.22 \%$ \\
3 & $1.22 \%$ \\
2 & $0.81 \%$ \\
2 & $0.81 \%$ \\
2 & $0.81 \%$ \\
2 & $0.81 \%$ \\
79 & $32.11 \%$ \\
\hline $\mathbf{2 4 6}$ & $\mathbf{1 0 0 \%}$
\end{tabular}


Prema Andres (2009) Bradfordov zakon utvrđuje da postoji inverzni odnos između broja radova u određenom predmetnom području i broja časopisa u kojima su ti članci objavljeni. Prema Bradfordovom zakonu časopise je moguće prezentirati u tri ranga prema broju članaka poštivajući kriterij da svaki rang obuhvaća podjednaki broj članaka koje objavljuje određeni broj časopisa koji će se rasprostraniti po zonama u odnosu $1: n: n^{2}$ (ibid.).

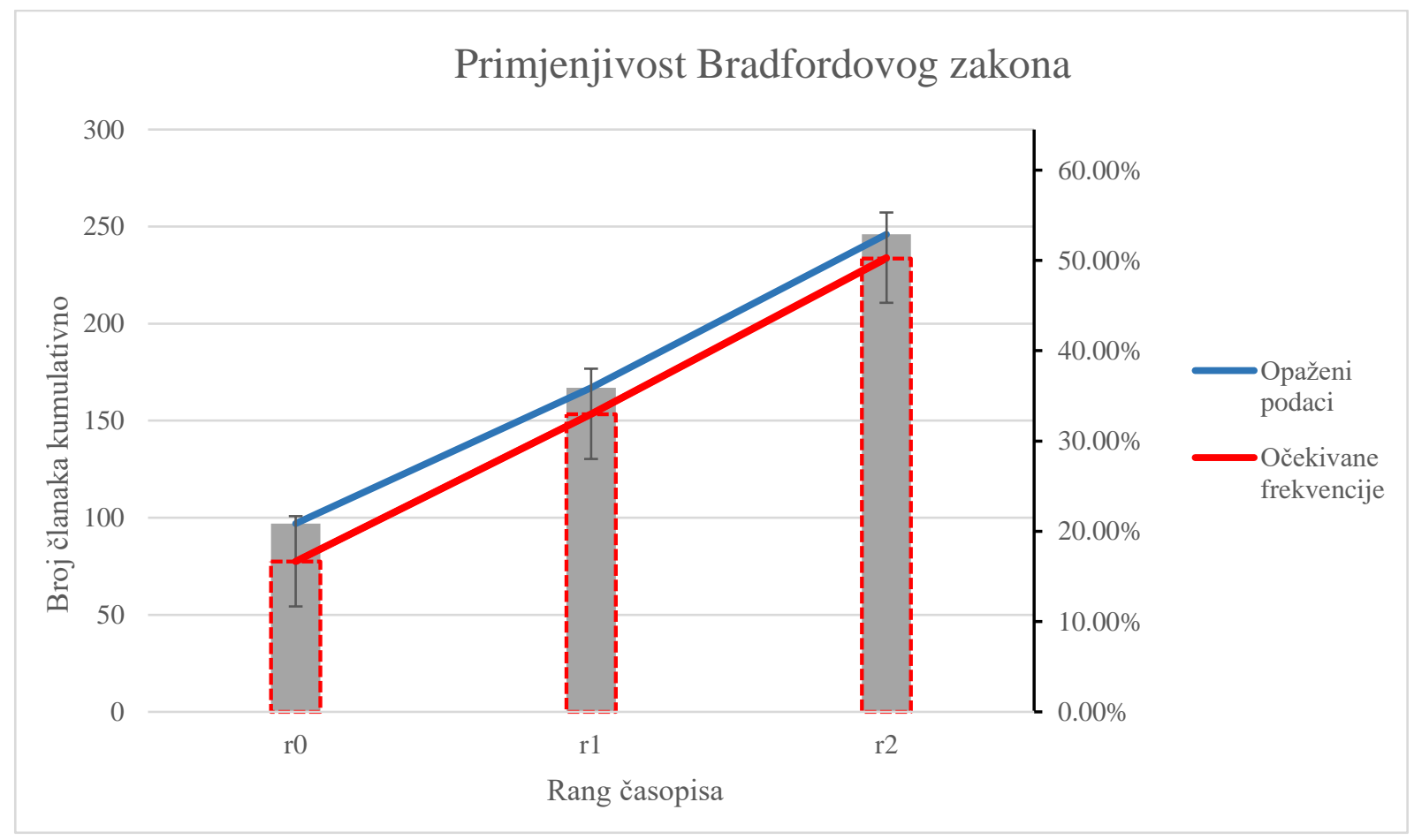

Slika 12. Primjenjivost Bradfordovog zakona na produktivnost autora u području integrativne bioetike

Istražena je primjenjivost Bradfordovog zakona za analizirani set literature u području integrativne bioetike prema izračunu u Prilogu 4. Utvrđeno je da literatura u području integrativne bioetike blago odstupa od očekivanih frekvencija prema Bradfordovom zakonu te da se časopisna produkcija može precizno organizirati u tri Bradfordove zone. Opažena odstupanja opaženih i očekivanih frekvencija provjerena su hi-kvadrat testom $\chi^{2}(2, \mathrm{~N}=246)$ $=7.09, p<.05$ te se može zaključiti da nema statistički značajne razlike između modela $\mathrm{i}$ opaženih frekvencija tj. $H_{o b}$ je odbačena jer postoji statistički značajna povezanost obrasca produktivnosti časopisa i očekivane dinamike produkcije prema Bradfordovom zakonu. 


\section{Produkcija članaka prema jeziku}

Prilozi u analiziranom setu najčešće se objavljuju na hrvatskome i engleskome jeziku i to $u$ približno podjednakom omjeru, no vrijedi i napomenuti da je približno $18 \%$ članaka koji spominju koncept integrativne bioetike objavljeno na drugim svjetskim jezicima. Prilozi u području objavljuju se na 11 različitih jezika.

Tabela 16. Prevalencija jezika obuhvaćenih radova

Jezik rada

Hrvatski jezik

Engleski jezik

Njemački jezik

Srpski jezik ${ }^{44}$

Španjolski jezik

Bosanski jezik

Portugalski jezik

Ukrajinski jezik

Mađarski jezik

Bugarski jezik

Talijanski jezik

N \%

124

$44.13 \%$

116

$41.28 \%$

14

$4.98 \%$

11

$3.91 \%$

8

$2.85 \%$

$3 \quad 1.07 \%$

1

$0.36 \%$

$1 \quad 0.36 \%$

$1 \quad 0.36 \%$

$1 \quad 0.36 \%$

$1 \quad 0.36 \%$

Total

\footnotetext{
${ }^{44}$ Četiri članka objavljena su na ćirilićnom pismu, te su isključena u fazi analize sadržaja. Uz njih isključeni su i svi članci na njemačkom, španjolskom, portugalskom, ukrajinskom, mađarskom, bugarskom i talijanskom jeziku. U analizi sadržaja ukupno je isključen 31 članak, stoga uzorak za analizu sadržaja broji 250 članaka.
} 


\section{Vrste doprinosa prema formalnim kategorizacijama priloga}

Posljednja vrste analize u bibliometrijskom dijelu rada odnosi se na formalno kategorizaciju priloga u časopisima čime se pokazuje da su prilozi u području najčešće kategorizirani kao izvorni znanstveni članci i pregledni radovi. Izvori podataka o kategorizacijama bili su sami članci, analizirane baze podataka, ali i mrežne stranice časopisa. Kategorizacije su člancima pridružene samo onda kada je podatak eksplicitno naveden u nekom od navedenih izvora podataka.

\section{Tabela 17. Kategorizacija radova}

\begin{tabular}{lcc} 
Jezik rada & $\mathbf{N}$ & \% \\
\hline Izvorni znanstveni članak & 83 & $29.54 \%$ \\
Pregledni članak & 42 & $14.95 \%$ \\
Prethodno priopćenje & 18 & $6.41 \%$ \\
Objavljeno izlaganje sa skupa & 18 & $6.41 \%$ \\
Stručni rad & 12 & $4.27 \%$ \\
Esej & 10 & $3.56 \%$ \\
Otvoreni komentar & 6 & $2.14 \%$ \\
Pismo uredniku & 3 & $1.07 \%$ \\
Kratko priopćenje & 2 & $0.71 \%$ \\
\hline Nema kategorizaciju & 52 & $18.51 \%$ \\
Poglavlje u knjizi & 35 & $12.46 \%$ \\
\hline Total & $\mathbf{2 8 1}$ & $\mathbf{1 0 0 \%}$
\end{tabular}




\section{Analiza sadržaja i fasetna analiza}

Pripremljeni analitički set članaka iz područja integrativne bioetike analiziran je induktivnim i deduktivnim pristupom. U fazi induktivne analize 250 članaka opisano je s preko 1400 individualnih kodiranja koji su određivali prepoznate središnje teme, fenomene i perspektive. Induktivno analizirani kodovi tema $(N=188)$ su potom razlomljeni na jednostavnije koncepte prema uputi Szostaka i suradnika (2016) kako bi se za klasifikaciju koristili osnovniji koncepti oko čijeg značenja postoji manje ambigviteta. Prilikom provođenja te redukcije očuvane su relacije pojedinog koda s dokumentima kojima su pripadali. Drugim riječima, u slučaju generiranja više kodova od jedne inicijalno kompleksnije teme multiplicirane su identične relacije za sve nove kodove koje je spram nekog dokumenta imao izvorni kod. Svođenje kodova na jednostavnije koncepte ponekad je zahtijevalo spajanje kodova koji su razlomljeni, a označavali su isti opseg značenja. Tako su primjerice individualna kodiranja za kodove kojima je označeno da se članci centralno bave poviješću bioetike u kontekstu Hrvatske ili Europe pridružena kodu koji je označava povijest bioetike općenito. Takva analiza dovela je do multipliciranja individualnih kodiranja, ali istovremeno i do redukcije konačnog broja kodova $(N=410)$ zbog preklapanja značenja nekih kodova.

Tako tretirana induktivno kreirana kodna struktura $\mathrm{u}$ idućoj je fazi komparirana $\mathrm{s}$ Klasifikacijom integrativnih razina. Za svaki je kod pretražena Klasifikacija integrativnih razina te je utvrđeno postoji li komparabilna ili identična klasa kojom bi se kod mogao označiti. Utvrđeni su kodovi koje možemo označiti nekom klasom iz Klasifikacije integrativnih razina, kodovi čija se notacijska oznaka može izraditi kao kompleksna oznaka kombiniranjem klasa fenomena i faseta prema pravilima za konstrukciju klasa Klasifikacije integrativnih razina. Najvrjedniji je pronalazak ovog mapiranja kodova na opću klasifikaciju fenomena identifikacija kodova za koje nije bilo moguće odrediti korelate u Klasifikaciji integrativnih razina. Konačno, u kodnu strukturu uključeni su i kodovi organizacijske naravi kojima nisu pridružena nikakva individualna kodiranja, ali koji najčešće predstavljaju klase gornjih razina iz Klasifikacije integrativnih razina pod kojima su zavedeni primjeri hijerarhijski nižih kodova koji se odnose na neka konkretna individualna kodiranja. Svi kodovi kojima je bilo moguće pridružiti neku notaciju svrstani su u hijerarhijski niz prema načelima redanja Klasifikacije integrativnih razina. Time je postignuto da se svi članci o pojedinoj predmetu grupiraju zajedno prema temeljnom fenomenu na koji se odnose pri čemu se u hijerarhijskom nizu prvo navode aspekti tj. perspektive iz kojih je pojedini fenomen na datoj razini kompleksnosti razmatran, a tek onda hijerarhijski niži fenomeni. 
Detaljniji prikaz rezultata analize sadržaja dan je u diskusijskom dijelu rada koji razmatra primjenjivost Klasifikacije integrativnih razina $\mathrm{u}$ području integrativne bioetike. Prikaz rezultata strukturiran je u četiri veće cjeline koje se odnose na raspravu o reprezentaciji temeljnih pojmova područja, reprezentaciju fenomena prema integrativnim razinama, reprezentaciju perspektiva kao odnosa fenomena i raspravu o razini ekspresivnosti Klasifikacije integrativnih razina u kontekstu njene primjene u području integrativne bioetike.

Tabela 18. Distribucija dokumenata prema glavnim klasama fenomena Klasifikacije integrativnih razina

Glavne klasa fenomena

N tematskih kodiranja

$\%$

\begin{tabular}{lrr}
\hline \#a forme & 1 & $0.20 \%$ \\
\#b prostorvrijeme & 5 & $1.02 \%$ \\
\#e atomi & 2 & $0.41 \%$ \\
\#h nebeska tijela & 4 & $0.82 \%$ \\
\#i stijene i minerali & 3 & $0.61 \%$ \\
\#j kopna i mora & 1 & $0.20 \%$ \\
\#k geni & 29 & $5.92 \%$ \\
\#m organizmi & 61 & $12.45 \%$ \\
\#n populacije & 9 & $1.84 \%$ \\
\#o djelovanje & 3 & $0.61 \%$ \\
\#p svijest & 29 & $5.92 \%$ \\
\#q jezik & 14 & $2.86 \%$ \\
\#r običaji & 23 & $4.69 \%$ \\
\#s zajednice & 103 & $21.02 \%$ \\
\#t politička uređenja & 8 & $1.63 \%$ \\
\#u pravni entiteti & 17 & $3.47 \%$ \\
\#v poduzeća & 89 & $18.16 \%$ \\
\#w artefakti & 7 & $1.43 \%$ \\
\#x umjetnine, kreativna djela & 12 & $2.45 \%$ \\
\#y znanje & 70 & $14.29 \%$ \\
\hline Total & $\mathbf{4 9 0}$ & \\
\hline
\end{tabular}




\section{DISKUSIJA}

Poglavlje o diskusiji donosi pregled značaja svih dosad prezentiranih rezultata počevši od teorijskih razmatranja, primjene bibliometrijskih postupaka te konačno rezultata analize sadržaja koja je iskorištena za kreiranje osnove za klasifikaciju u području integrativne bioetike.

U teorijskom dijelu rada prikazan je razvoj područja organizacije znanja sve do njegovog trenutnog stadija. U kritici disciplinarnog temelja tradicionalnih sustava za organizaciju znanja utemeljeni su razlozi interesa za interdisciplinarnu i transdisciplinarnu organizaciju znanja te je iskazana potreba za daljnjim istraživanjima različitih domena znanja i njihove kompleksnosti. Kao primjer takvog područja predstavljena je integrativna bioetika i objašnjena potreba toga područja da se znanje u njemu učini dostupnim prema perspektivama koje sudjeluju u bioetičkoj raspravi kako u znanstvenom tako i izvan znanstvenog konteksta što je zadatak osiguranja predmetnog pristupa smjestilo u područje transdisciplinarne organizacije znanja. Uparimo li Čovićevu definiciju kulturnih perspektiva s Jurićevom definicijom transdisciplinarnosti možemo zamijetiti da je zadatak transdisciplinarne organizacije znanja u području integrativne bioetike dvojak. S jedne strane akteri transdisciplinarnosti i aktivni tražitelji povezanog znanja u cjelini njegovih aspekata mogli bi biti filozofi, znanstvenici i istraživači iz područja bioetike same, a s druge strane to bi mogli biti i nositelji kulturnih perspektiva tj. nositelji svih onih oblika „,kulturne $i$ društvene osviještenosti koji nastaju izvan sustava znanosti uopće, dakle izvan okvira u kojem se stvara metodološki strukturirano, deskriptivno (egzaktno) i normativno znanje“ (Čović, 2007, str. 73). Autori u području organizacije znanja pristupe transdisciplinarnoj organizaciji znanja supsumiraju pod interdisciplinarnu organizaciju znanja polazeći od pretpostavke o jedinstvu svih stvari koje je moguće reprezentirati samo ako napustimo klasifikacijske prakse koje unaprijed preferiraju određene disciplinarne perspektive te discipline same kao osnovu za organizaciju znanja. Zasnivanjem klasifikacije fenomena u teoriji integrativnih razina osigurana je ona vrsta vizije transdisciplinarnosti kakvu Basarab Nicolescu (1994) traži u drugom članku proklamacije o transdisciplinarnosti koji se odnosi na prihvaćanje ideje o postojanju različitih razina stvarnosti kojima upravljaju različite vrste logike kao i pozicije da stvarnost nije svodiva na jednu od tih razina ili njenu logiku. Slijedom tih teorijskih određenja transdisciplinarnosti i potreba koje proizlaze iz definicije transdisciplinarnog rada u području integrativne bioetike i kulturnih perspektiva izvanznanstvenih aktera znanje se u domeni integrativne bioetike mora organizirati koristeći one sustave i organizacijske principe koji će u 
perspektivi budućeg razvoja područja omogućiti što sustavniju reprezentaciju kompleksnosti jedinstva sveg znanja čiji se aspekti mogu preklapati pa čak i na razini spoznajnih perspektiva biti međusobno kontradiktorni. Drugim riječima jamstvo perspektive u transdisciplinarnoj organizaciji znanja postiže se reprezentacijom tog jedinstva koje je Čovićevim (2007, str. 67) riječima „umnogostručeno u svojim aspektima“.

Jedini je dovoljno razrađeni projekt koji tako pojmi znanje već predstavljena Klasifikacija integrativnih razina pa se stoga jedan dio ovog doktorskog istraživanje na metodološkoj razini može tretirati kao analiza primjenjivosti toga sustava na područje integrativne bioetike.

Poduzeta bibliometrijska analiza pokazala je da je primjenom kvantitativnog kriterija u odabiru relevantnih priloga koji se odnose na pojam integrativne bioetike moguće to područje konstituirati kao domenu znanja koja unutar sebe funkcionira kao diskurzivna zajednica koja se samoorganizira sukladno očekivanim obrascima produkcije. U teorijskom djelu rada prikazano je da je riječ o domeni koja ima relativno jasnu ontološku bazu i pozadinsku teleologiju koja se ponajprije očituje u konceptu pluriperspektivizma. Ono što preostaje jest prikazati sadržajnu strukturu područja integrativne bioetike s obzirom na centralne teme priloga u području te analiza izazova i zahtjeva klasifikacije tih priloga u kontekstu onih sustava za organizaciju znanja koji su primjereni za interdisciplinarno i transdisciplinarno orijentirana područja znanja.

Prije diskusije o rezultatima analize važnim se čini i pojašnjenje razlike između zadaća područja bioetike i područja klasifikacije. Kao jednu od zadaća bioetike Jurić ističe stvarnu integraciju perspektiva. Kada govori o bioetici ističe da njoj ne može biti dovoljno tek mehaničko okupljanje raznolikih perspektiva, već da se razlike pozicija trebaju u dijalogu stopiti u jedinstveni bioetički pogled (Jurić, 2017). Ta integracija ne može postati zadaća klasifikacije jer se ona nužno zbiva izvan njene domene i njenih postupaka te bi svako „,kreativno“ klasificiranje integracije narušilo kredibilitet sustava da podržava i vjerno reprezentira aktualne epistemičke dosege. Klasifikacija može tek post-factum reprezentirati sve one potencijalne rezultate integracije perspektiva. Pojam kreativno ovdje se misli pejorativno te se takva klasifikacija može tumačiti kao svaki onaj pokušaj zasnivanja klasifikacije koji ne polazi od neke vrste jamstva, bilo da je riječ o literarnom, epistemološkom, kulturnom ili drugim oblicima jamstva, i koja zbog svoje neutemeljenosti zapravo kontraproduktivno dezorijentira tražitelje znanja i informacija. Klasifikaciji se, za razliku od bioetike, ne može predbaciti mehaničko okupljanje perspektiva tj. identifikacija 
perspektiva u interakciji vezano za neki bioetički problem jer je upravo to njena zadaća. Tek tako postavljena klasifikacija može razmišljati o načinima oslobađanja epistemoloških potencijala djela (cf. Hjørland, 1992) koja opisuje te ih klasificirati s obzirom na neke objektivne osobitosti dokumenta ili s pozicije nekog nadređenog ili općenitijeg pogleda. 


\section{Reprezentacija temeljnih pojmova}

Na temelju provedene analize sadržaja utvrđena je potreba i da se neki temeljni termini odrede u odnosu na dostupna rješenja za njihovu klasifikaciju. U nastavku navodimo temeljne pojmove prema klasama koje su za njih dostupne u Klasifikaciji integrativnih razina, a onda ih i komentiramo s pozicije aktualne klasifikacijske prakse u području bioetike i filozofije ${ }^{45}$.

$\begin{array}{ll}\text { \#s6 } & \text { moral, moralna refleksija } \\ \text { \#06 } & \text { teorijske perspektive } \\ \text { \#s6 (0 6) } & \text { etička refleksija; teorije o moralu } \\ \text { \#0 } & \text { disciplinarne perspektive } \\ \text { \#s6 (07) } & \text { moral iz perspektive neke discipline } \\ \text { \#073 } & \text { perspektive diskurzivnih zajednica } \\ \text { \#s6 (073) } & \text { moral iz perspektive neke diskurzivne zajednice } \\ \text { \#yshr } & \text { zabilježeno znanje o etici kao filozofskoj disciplini } \\ \text { \#07hr } & \text { filozofska etika; etika iz perspektive filozofije } \\ \text { \#s6(07hr) } & \text { moral iz perspektive filozofske etike }\end{array}$

Na temelju gornjih klasa iz Klasifikacije integrativnih razina možemo uvidjeti da je njome moguće izraziti razlike između morala i etike, moralne refleksije i etičke refleksije (kao što to primjerice čini Čović, 2011) te iste kvalificirati nekim perspektivama kao što je to slučaj kod filozofske etike. Važno je naglasiti da se klasifikacija neće baviti prosudbom teorijske legitimnosti neke pozicije o moralu i njome će nužno morati biti omogućen prikaz dokumenata čija je teorijska legitimnost upitna te će klasifikacija biti ustrojena tako da bude adekvatna za prikaz pluralizma različitih pozicija o etici, ali i o moralu tj. moralnog relativizma. No, ta određenja neće biti princip strukturiranja same klasifikacijske sheme već će se te pozicije uvijek iskazivati analitičko-sintetičkim metodama i isključivo u okvirima praktičke dimenzije klasifikacije koja označava njenu snagu i agendu da može reprezentirati sve ono mislivo što je u nekom trenutku bilo zabilježeno. Prikazani pojmovi također pokazuju mogućnost reprezentiranja navedenih temeljnih pojmova tako da ih se istovremeno uvrštava $u$

\footnotetext{
${ }^{45}$ Klase su prikazane u slobodnom rasporedu kako bi se pokazala njihova tvorba.
} 
neki opći sustav znanja i znanosti koji omogućava povezivanje dokumenata prema svim izrazivim aspektima.

Kada za razliku od dokumenata koji zauzimaju neku specifičnu poziciju spram morala ili etike želimo govoriti o dokumentima koji govore o samom moralnom pluralizmu ili o moralnom relativizmu tada nam više koriste nove spoznaje u teoriji klasifikacije koje dolaze od Kleineberga (2016) koji smatra da Klasifikacija integrativnih razina mora razviti u intelektualnoj povijesti utemeljene integrativne razine epistemičkih okvira i nazora u kojima bi i relativizam našao svoje mjesto, jer to trenutno nije slučaj, a time i nije izrazivo tom klasifikacijom.

\section{Bioetika}

Klasifikacija područja bioetike pomoću Klasifikacije integrativnih razina mora poći od predstavljenog pluralizma definicija bioetike. Kao osnovu te analize uzet je pregled definicija bioetike Hrvoja Jurića (cf. Jurić, 2017) objašnjen u poglavlju o integrativnoj bioetici. Klasifikacija područja koje je određeno pluralizmom definicija nema drugog izbora osim dosljedne reprezentacije tog pluralizma. Klasifikacija se ne može upustiti u kvalifikaciju primjerenosti i sveobuhvatnosti pojedinačnih definicija jer bi time onemogućila sistematični pristup pojedinim gledištima. Drugim riječima, klasifikacija ne može i ne smije pokušavati razriješiti terminološke probleme bioetike. Bilo kako bilo, klasifikacija ipak može nastojati uočiti neke zajedničke karakteristike pojedinih pozicija i na temelju toga ponuditi načine njihovog okupljanja te ih implementirati ako se pokaže da je identificirani način okupljanja relevantan i potrebit. Jurićeva grupiranja možemo za potrebe klasifikacije dalje grupirati u dvije skupine tj. ona usmjerena na disciplinarno određenje bioetike $\mathrm{i}$ ona usmjerena na njeno interdisciplinarno određenje.

Govorimo li o bioetici u disciplinarnim terminima „kao dijelu filozofske etike, ili preciznije, kao grani primijenjene etike“ (ibid., str. 130) potrebno je ponovno istaknuti da Klasifikacija integrativnih razina, bez obzira na to što je po vrsti klasifikacija fenomena, omogućuje reprezentaciju disciplinarnih perspektiva. Neke od već spomenutih klasa i tretmana pojmova morala, etike i filozofije bila bi relevantna i za specifikaciju bioetike u ovome opsegu. Slijedeći istu logiku, odredimo li bioetiku ,,kao disciplinu koja se bavi pitanjima kliničke prakse, zdravstvenih sustava, bioloških, biomedicinskih i farmaceutskih istraživanja kao $i$ drugim pitanjima ljudskog života i zdravlja uopće“ (ibid., str. 128) relevantnima se čine klase 
koje bioetiku određuju kao medicinsku, kliničku, biomedicinsku etiku ili etiku javnog zdravstva.

Kada govorimo o posljednje dvije vrste definicija (tj. o bioetici „,kao interdisciplinarno zasnovanoj znanosti o preživljavanju čiji je glavni cilj izgradnja mostova između humanističkih i prirodnih znanosti“ (ibid., str. 128), odnosno o bioetici kao „otvorenom području susreta $i$ dijaloga različitih znanosti $i$ djelatnosti, te različitih pristupa i pogleda na svijet, koji se okupljaju radi artikuliranja, diskutiranja i rješavanja etičkih pitanja vezanih za život, život u cjelini $i$ u svakom od dijelova te cjeline, za život u svim njegovim oblicima, stupnjevima, fazama i pojavnostima") tada se relevantnima čine nekoliko mogućih rješenja.

Prvi vid interdisciplinarno shvaćene bioetike mogao bi se klasificirati pomoću oznake za interdisciplinarnost, no sama Klasifikacija integrativnih razina predviđa da se klasa za interdisciplinarnost tvori analitičko-sintetički. Pritom bismo interdisciplinarnost mogli shvatiti kao interakciju dviju ili više disciplina koja je po naravi holistička ili integrirajuća. Ovdje je uputno napraviti razgraničenje u klasama multi-, inter- i transdisciplinarnosti.

Općeprihvaćeno tumačenje razlike multidisciplinarnosti i interdisciplinarnosti jest da se ona sastoji u tome da multidisciplinarni pristupi uvijek nastoje doseg svoga djelovanja zadržati unutar granica polazišnih disciplina koje se paralelno bave istim istraživačkim temama (Nicolescu, 2014). Interdisciplinarni pristup za razliku od toga podrazumijeva i transfer metodologija te nastoji sintetizirati poveznice između disciplina, no ne izlazi iz granica disciplinarnog konteksta u cjelini (ibid.). Transdisciplinarnost pak transcendira $i$ te granice te je znatno usmjerena na odnos tehno-znanstvenog kompleksa i društva u cjelini, a posebice u kontekstu rješavanja kompleksnih problema na koje znanost i tehnologija ne mogu samostalno odgovoriti. Sljedeće su klase stoga primjerene:

multidisciplinarnost > discipline, $\mathrm{u}$ interakciji s, disciplinama interdisciplinarnost $>$ discipline, $\mathrm{u}$ interakciji s, disciplinama, holistički transdisciplinarnost $>$ discipline, $\mathrm{u}$ interakciji s, društvom, holistički

Polazeći od klase za interdisciplinarnost jedno bi od rješenja za interdisciplinarnu bioetiku moglo biti dovođenje te klase u opći odnos s klasama za prirodne \#yss i humanističke znanosti \#ysuWy, no takva bi klasifikacija bila vrlo nepraktična u sustavu koji primarno okuplja izvore o bioetici. Alternativno, i po mišljenju autora, primjerenije rješenje bilo bi 
tretiranje ove definicije iz perspektive života i djela Vana Rensselaera Pottera (vidi rješenje na kraju sekcije).

Posljednja od ponuđenih definicija u središte razmatranja bioetike postavlja fenomen života. Shodno tome, bioetiku bi se moglo odrediti kao interdisciplinarno usmjerenu znanost o životu \# kWn no tada je ne bismo mogli razlikovati od drugih znanosti o životu (engl. life sciences). Također, treba zamijetiti da se prema toj definiciji bioetika zapravo ne određuje kao znanost, već kao „otvoreno područje susreta i dijaloga“ (Jurić, 2017, str. 128). Jedan od načina definiranja bioetike koji bi mogao u tom smislu biti sveobuhvatan iz perspektive suvremenosti bioetičke rasprave jest njena klasifikacija pod oznakom za zajednice koje prioritiziraju život i koje očuvanje života tretiraju kao vrijednost. Uzme li se u obzir Jurićevo mišljenje da u određenju bioetike nije potrebno ustrajati na scijentizaciji i disciplinizaciji bioetike već ga tretirati kao područje u trajnom stanju neodređenosti takvo bi se klasificiranje područja moglo pokazati izrazito korisnim. Tako bismo područje bioetičkog interesa mogli obujmiti klasom:

$$
\# \mathrm{~s} 60 \mathrm{kWn} 46
$$

Takva je klasa posebno precizna jer je u Klasifikaciji integrativnih razina život definiran kao raspon integrativnih razina koji obuhvaća sve od razine gena do populacija tj. gene, stanice, organizme i populacije što korespondira s Jurićevom definicijom života „, u cjelini $i$ u svakom od dijelova te cjeline, ... život u svim njegovim oblicima, stupnjevima, fazama i pojavnostima“ (ibid., str. 128). Ova je definicija dovoljno obuhvatna da okupi i ono što Jos Schaefer Rolffs naziva znanstvenom bazom bioetike koju određuje kao etiku živog (engl. ethics of the living), ali i sve izvanznanstvene i društvene aspekte bioetičke rasprave.

Konačno, za kontekst lokalne primjene u zbirkama koje pretežito okupljaju građu iz područja bioetike klasifikatori bi se mogli poslužiti primjenom tzv. deiktičkih klasa koje predviđa Klasifikacija integrativnih razina. Deiktička klasa, primjerice označena velikim početnim slovom \#B značajno bi umanjila ambigvitet koji proizlazi iz različitih definicija bioetike jer bi se njen opseg mogao opisno definirati, bilo da bi se njome okupljao sav ili samo dio pluraliteta postojećih definicija. Za tako tretiranu klasu bioetike možemo navesti i neke od složenih oznake koje se pojavljuju u analiziranom setu:

$$
\begin{array}{ll}
\text { \#B } & \text { bioetika } \\
\text { \#B063 Čovi } \text { Ć}^{47} & \text { integrativna bioetika, bioetika prema Čoviću }
\end{array}
$$

\footnotetext{
${ }^{46}$ Neke od predloženih klasa razvijene su u zajedničkoj raspravi autora doktorskog rada i profesora Claudija Gnolija sa Sveučilišta u Paviji putem email korespondencije u period od 2018. do 2021. godine.
} 


$\begin{array}{ll}\text { \#B063Potter } & \text { globalna bioetika, bioetika prema Potteru } \\ \text { \#B23jdWm } & \text { bioetika, u Europi } \\ \text { \#B0P } & \text { integrativna bioetika, bioetika razmatrana pluriperspektivistički } \\ \text { \#B90h } & \text { kozmobioetika } \\ \text { \#B90hU } & \text { bioetika Zemlje } \\ \text { \#rt0B } & \text { bioetika, teološka } \\ \text { \#B90vy5t67y } & \text { integrativna pedagoška bioetika }\end{array}$

\section{Integrativna bioetika i pluriperspektivizam}

Za klasifikaciju dokumenata čija je središnja tema upravo koncept integrativne bioetike primjenjiva su i neka od već ponuđenih rješenja za područje bioetike u cjelini jer se integrativna bioetika ne određuje kao podvrsta bioetike već kao njena razvojna faza. To je onaj stupanj razvoja bioetike koji bioetiku tretira kao ,pluriperspektivno područje u kojem se u interakciji raznorodnih perspektiva stvaraju uporišta za orijentaciju u pitanjima koja se odnose na život ili na uvjete njegova održanja“ (Čović, 2011, str. 21). Uzevši da orijentacija prema istom autoru nije moguća isključivo unutar disciplinarnog konteksta relevantnom se čini ponuđena klasa koja označava transdisciplinarne pristupe. Ako bismo pak područje htjeli odrediti kao pluriperspektivno područje u smislu da se pluriperspektivizam tretira kao metoda morali bismo ga moći odrediti u odnosu na perspektivizam kao specifičan epistemološki nazor, no Klasifikacija integrativnih razina još uvijek ne nudi neku poopćenu hijerarhiju epistemičkih okvira. Provizorno, koncept integrativne bioetike mogao bi se tvoriti kombinacijom dviju deiktičkih klasa gdje bi se deiktička klasa za pluriperspektivizam aspektno kombinirala s klasom \#B bioetika.

\footnotetext{
${ }^{47}$ Lokalne klase koje se odnose na doprinose pojedinih autora navedene su ilustrativno te ne slijede u potpunosti pravila Klasifikacije integrativnih razina.
} 


\section{Fenomeni prema integrativnim razinama}

Zanimljiv, iako možda očekivan, pronalazak provedene analize sadržaja jest da se područje integrativne bioetike značajno ne bavi fenomenima prije integrativne razine gena koja je ujedno i početna razina kojom je u klasifikaciji obuhvaćen pojam života. Prethodne razine \#a formi, \#b prostorvremena, \#c opni, \#d energije, \#e atoma, \#f molekula, \#g kontinuiranih tijela, \#h nebeskih tijela, \#i stijena i minerala i \#j kopna i mora tek su sporadično referencirane u području. Iznimka od toga jest raspon klasa koji označava prirodu u cjelini \#bWo ili kada se fokus interesa bioetike želi odrediti u odnosu na \#h kozmos ili \#hU Zemlju kao planet.

\section{Život \#kWn}

Individualna kodiranja povezana s fenomenom života visoko su prevalentna u analiziranom setu pri čemu se fenomen života pojavljuje u 30 dokumenata kao dio definicije centralne teme toga dokumenta. Rečeno je da je život definiran kao raspon entiteta od gena do populacija, no klasifikacija ga u apelaciji također određuje skup fenomena koji su predmet bavljenja biologije kao discipline. Život se pojavljuje u različitim kontekstima poput:

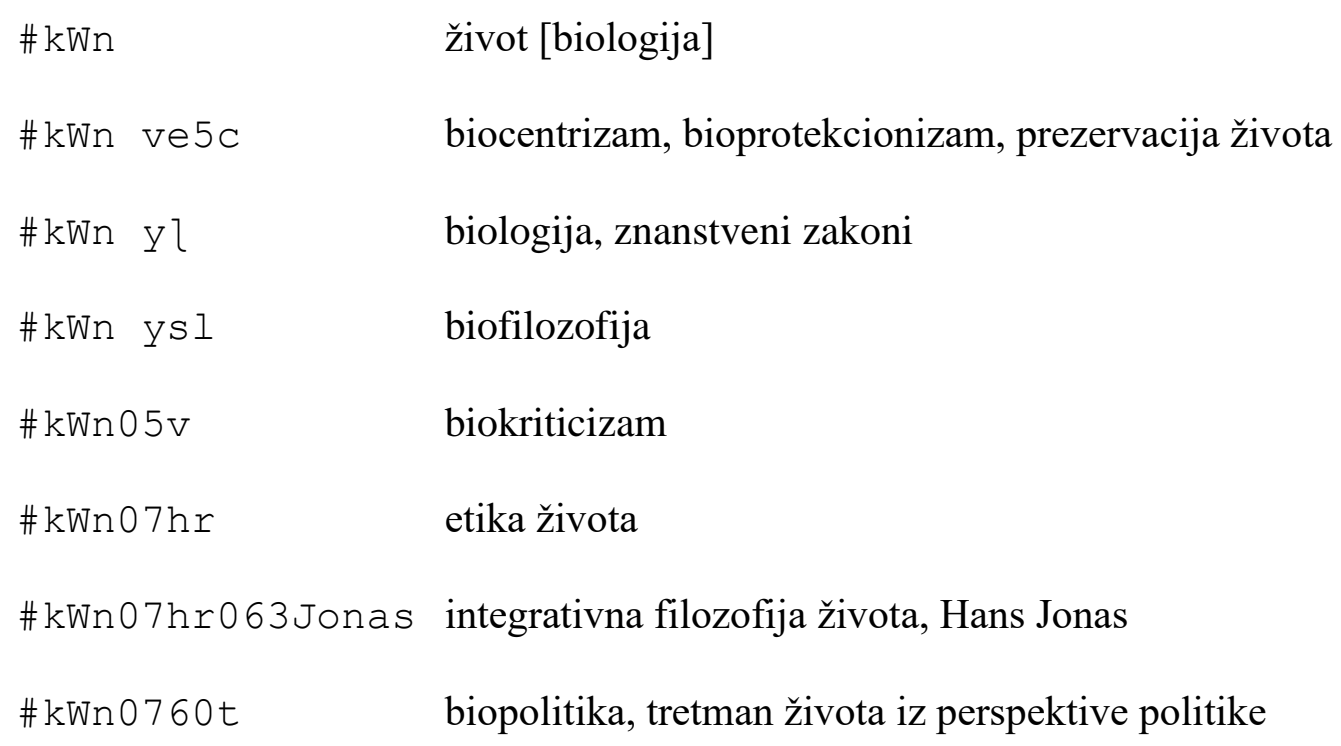

Neki od kodova traže dodatno pojašnjenje. Biocentrizam i bioprotekcionizam tretirani su kao prezervacijski, konzervacijski pogled na sve oblike života. Pogledamo li klasu za biofilozofiju uočavamo ograničenje Klasifikacije integrativnih razina da jasno napravi ono razgraničenje koje Jurić (2015) definira kao razliku između života kao zoe i života kao bios tj. života naprosto i pojedinih oblika ili načina života svojstvenog nekim pojedincima ili grupama. Oba značenja podrazumijevaju se pod klasom \# kWn. Klasa etika života predstavlja disciplinarni etički pogled na život, dok sljedeća klasa specificira i nazor specifičnog filozofa kao temu djela. Posljednja klasa umjesto disciplinarnog pogleda govori o politici kao domeni ljudskih 
aktivnosti. Područje integrativne bioetike rjeđe će se fokusirano baviti integrativnom razinom gena, pri čemu od tog pravila odstupa rad Ivice Kelama iako se za njegov rad može zamijetiti da gene nužno razmatra u kontekstu njihove tehnološke manipulacije što će biti reprezentirano tek na najvišim i znatno kompleksnijim razinama integracije.

\section{Organizmi \#m}

Područje znanja od posebnog interesa za integrativnu bioetiku vezano je za integrativnu razinu organizama. Zanimljivost ove razine mogla bi se objasniti istim argumentum kao i za prethodnu. Naime, specifične klase koje označavaju pojedinačne fenomene organizama rijetko su centralni tematski interes. Za razliku od toga organizmi kao fenomeni najčešće se razmatraju u kontekstima koji oznake tema crpe s viših integrativnih razina bilo da je riječ o tehnologijama, disciplinarnim ili pravnim perspektivama.

Prikaz relevantnih fenomena možemo započeti od klasa pojedinih vrsta fenomena:

$\begin{array}{ll}\# \text { mp } & \text { biljke } \\ \text { \#mpwbtgf } & \text { pšenica } \\ \# \text { mq } & \text { životinje } \\ \text { \#mqriqx } & \text { pčele } \\ \text { \#mU } & \text { čovjek }\end{array}$

Ovi fenomeni često su kvalificirani aspektima unutar iste razine integracije:

\begin{tabular}{|c|c|}
\hline \# m 4 & bolest \\
\hline$\# \mathrm{~m} 5 \mathrm{x}$ & smrt, ortotanazija \\
\hline$\# \mathrm{~m} 8 \mathrm{~d} 5 \mathrm{x}$ & smrt fetusa, pobačaj \\
\hline \#m8l & adolescencija \\
\hline \#mq4 9b & životinje, osjećaj boli \\
\hline \#mU5g8i & razvoj ljudskog djeteta \\
\hline \#mU7 & ljudsko tijelo, svi dijelovi tijela kao sustav \\
\hline
\end{tabular}

Konačno, različite perspektive razmatranja integrativne razine organizama lociramo u:

\#m5x6w98f smrt, loša, distanazija 


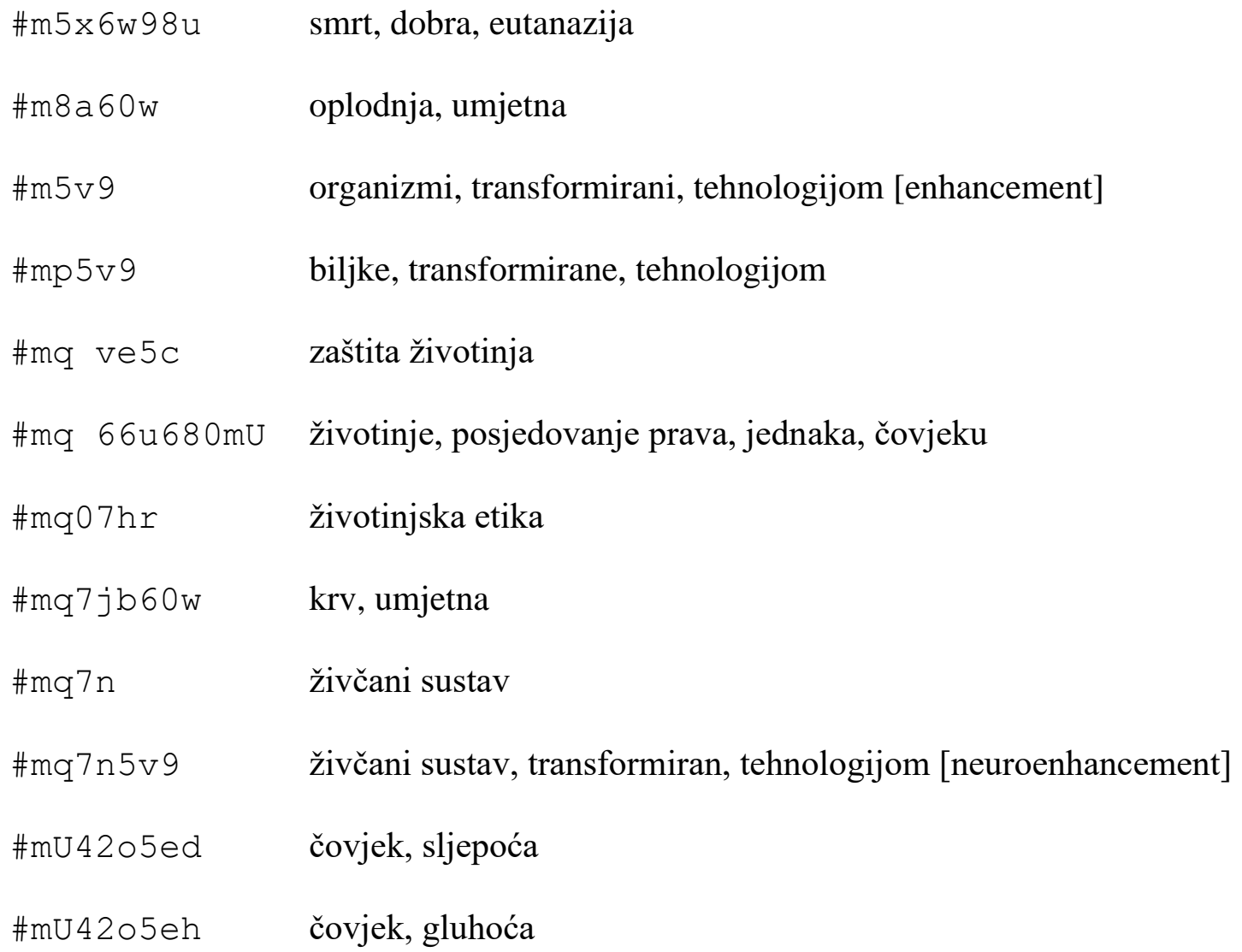

U klasi organizama predviđena je posebna deiktička klasa kojom se kraticom označava čovjek. To je učinjeno zbog toga što klasifikacija nastoji umanjiti antropocentrizam koji je prisutan u drugim klasifikacijama pa je tako čovjek ovdje klasificiran tek kao jedna od životinja. No, s obzirom na to da je u primjene klasifikacija vrlo često korisno i potrebno građu koja se odnosi na čovjek istaknuti i učiniti dostupnijom deiktička klasa \#mU služi kako bi se u redanju klasa favoriziralo ljudsku perspektivu, ako je to potrebno. Na tom pragu treba primijetiti da klasifikacija ne predviđa olakšani način isključivanje ljudskog pogleda koji bi u području integrativne bioetike mogao biti koristan s obzirom na to da se biljke i životinje koje nisu ljudi često određuje kao ne-ljudska živa bića, odnosno ne-ljudske životinje. Negativne preferencije omogućile bi dodatnu ekspresivnost klasifikacije.

U drugoj prezentiranoj skupini klasa kvalificiranih aspektima unutar iste razine integracije zanimljiva je klasa kojom je označen abortus. Naime, ovako definiran abortus označen je kao smrt fetusa što bi se moglo tumačiti kao da se pobačaj ne može odrediti kao smrt koja se zbiva u ranijim stadijima gestacije. Klasifikacija ovdje preferira određenu perspektivu, no istom logikom tvorenja ove oznake abortus bi se mogao opisati i kao smrt tek začetog bića ili bi se pak neki teološki pogled mogao izraziti kvalificiranjem trenutno preferiranog rješenja nekom od faseta kojima je moguće označiti poglede s obzirom na religiju koja ih oblikuje. 
Temeljna je razlika između druge i treće skupine klasa u tome što treća skupina crpi dodatna određenja aspekata iz klasa viših razina. Tako je eutanazija određena kao smrt koja je dobra tj. ta njena kvaliteta crpi se iz onih dijelova klasifikacije koji pretpostavljaju svijest koja u okviru nekih zajednica i u kontekstu specifičnih djelatnosti neki postupak kvalificiraju kao dobar ili loš. Zamijećeno je da klasa koja se odnosi na faze i vrste medicinskog tretmana ne predviđa potklasu za njegov namjerni prestanak. Moguće je specificirati liječnika kao aktera prevencije, prve pomoći, dijagnoze, samog medicinskog tretmana, ali ne i kao aktera koji uzrokuje prestanak života pacijenata.

\section{Populacije \#n}

Integrativna razina populacija popisuje različite vrste biocenoza i ekosustava. Prepoznate teme u području integrativne bioetike:

$\begin{array}{ll}\text { \#n5v } & \text { biodiverzitet } \\ \text { \#nmU07hr } & \text { populacijska etika } \\ \text { \#nu } & \text { biotička zajednica, biocenoze } \\ \text { \#ny } & \text { okoliš, ekosustav } \\ \text { \#nyo } & \text { tla }\end{array}$

\section{Svijest \#p}

U kontekstu svijesti gdje se misli na individualnu svijest nekog subjekta definiraju se psihička obilježja pojedinaca poput emocija, karakteristika osobnosti, razina svjesnosti i vrsta kognicije. Karakteristične teme:

$\begin{array}{ll}\# \text { p07h } & \text { filozofija psihe } \\ \# \text { p4 } & \text { mentalne, psihičke bolesti } \\ \# \text { p6m } & \text { odgoj } \\ \text { \#p6u } & \text { društvena pravda } \\ \# \text { p7 } & \text { vještine } \\ \text { \#pex } & \text { povjerenje } \\ \text { \#pex36y8v } & \text { povjerenje u stručnjake } \\ \text { \#poe } & \text { sjećanja }\end{array}$




$\begin{array}{ll}\text { \#poe9stWsy } & \begin{array}{l}\text { kultura sjećanja, sjećanje u odnosu na civitiz } \\ \text { civilizacijsko sjećanje }\end{array} \\ \text { \#powh6f } & \text { tjelesna kultura; navike fizičke aktivnosti } \\ \text { \#ps } & \text { osoba, self, identitet } \\ \text { \#ps42s60sb } & \text { narcizam } \\ \text { \#px5 } & \text { biografija } \\ \text { \#px90vu } & \text { medicinsko osoblje, doktor }\end{array}$

\section{Kultura \#qWy i Jezik \#q}

Rasponom od klase koja označava jezik do posljednje klase u klasifikaciji označena je integrativna razina kulture \#qWy kojom su indeksirani dokumenti koji se specifično odnose na različita kulturološka razmatranja bioetike, a specifično u multikulturnom i interkulturnom kontekstu. Ovdje vrijedi spomenuti da razlikovanje multikulturalizma i interkulturalizma nije predviđeno klasifikacijom te ono predstavlja izazov i onda kada se isto razlikovanje nastoji uspostaviti analitičko-sintetički. Slično kao i u slučaju pluriperspektivizma, ovi kompleksni nazori koji su i sami višeznačni, nisu u Klasifikaciji integrativnih razina prezentirani u okviru nekog šireg sociološkog ili političkog teorijskog okvira. Iako je moguće načelno označiti kulturalnu varijabilnost zabilježenog znanja tu različitost nije još uvijek moguće odrediti u nekom jasnom teorijskom kontekstu pa time niti razlike između pristupa.

Integrativna razina jezika dolazi do izražaja u kontekstu komunikativnih funkcija kao u onim dokumentima koji se centralno bave temom kritičke prosudbe ili metaforičkim oblicima izražavanja. Relevantne su sljedeće klase:

$$
\begin{array}{ll}
\# q 9 \mathrm{v} & \text { kritika, prosuđivanje } \\
\# q 99 \mathrm{~m} & \text { metaforički smisao, metafore } \\
\# \text { qvdnyn } & \text { ubuntu; Zulu }
\end{array}
$$

\section{Običaji \# $r$}

Klasa se odnosi na različite vrste običajnosti, duhovnosti, tradicije, religije itd. Pojedinačne religije ovdje se prikazuju kao centralne teme, dok su različite vrste religijskih perspektiva zastupljene u drugom dijelu ovog prikaza. Karakteristične teme:

$$
\text { \#r7s6rtu Kur'an, religijski tekstovi, Islam }
$$




$\begin{array}{ll}\# \text { r88e } & \text { sekularno, svjetovno, laičko } \\ \# \text { r88u } & \text { sakralno } \\ \# r r & \text { religija } \\ \# \text { rr03r } & \text { kritika religije } \\ \# \text { rt } & \text { vjera [teologija] } \\ \text { \#rt90A } & \text { panteizam } \\ \text { \#rtt } & \text { kršćanstvo } \\ \text { \#rtpp } & \text { pijetizam } \\ \text { \#rtu } & \text { Islam }\end{array}$

\section{Zajednice \#s}

Klasa koja označava zajednice najzastupljenija je klasa fenomena u analiziranom setu literature. Klasa za feminizam složena je oznaka za specifične teorijske pristupe koji, čini se, još uvijek nemaju posebno definirano mjesto u klasifikaciji, ali intencija kreatora bila je odrediti feminizam kao vrstu društvene perspektive. Vrste različitih etičkih precepata navode se pod \#s6. Sve klase pod \#s 7 reprezentiraju kvalifikacije zajednica prema nekom kriteriju. Manjinske zajednice i etniciteti mogu se dalje specificirati dodatno definiranim fokusima.

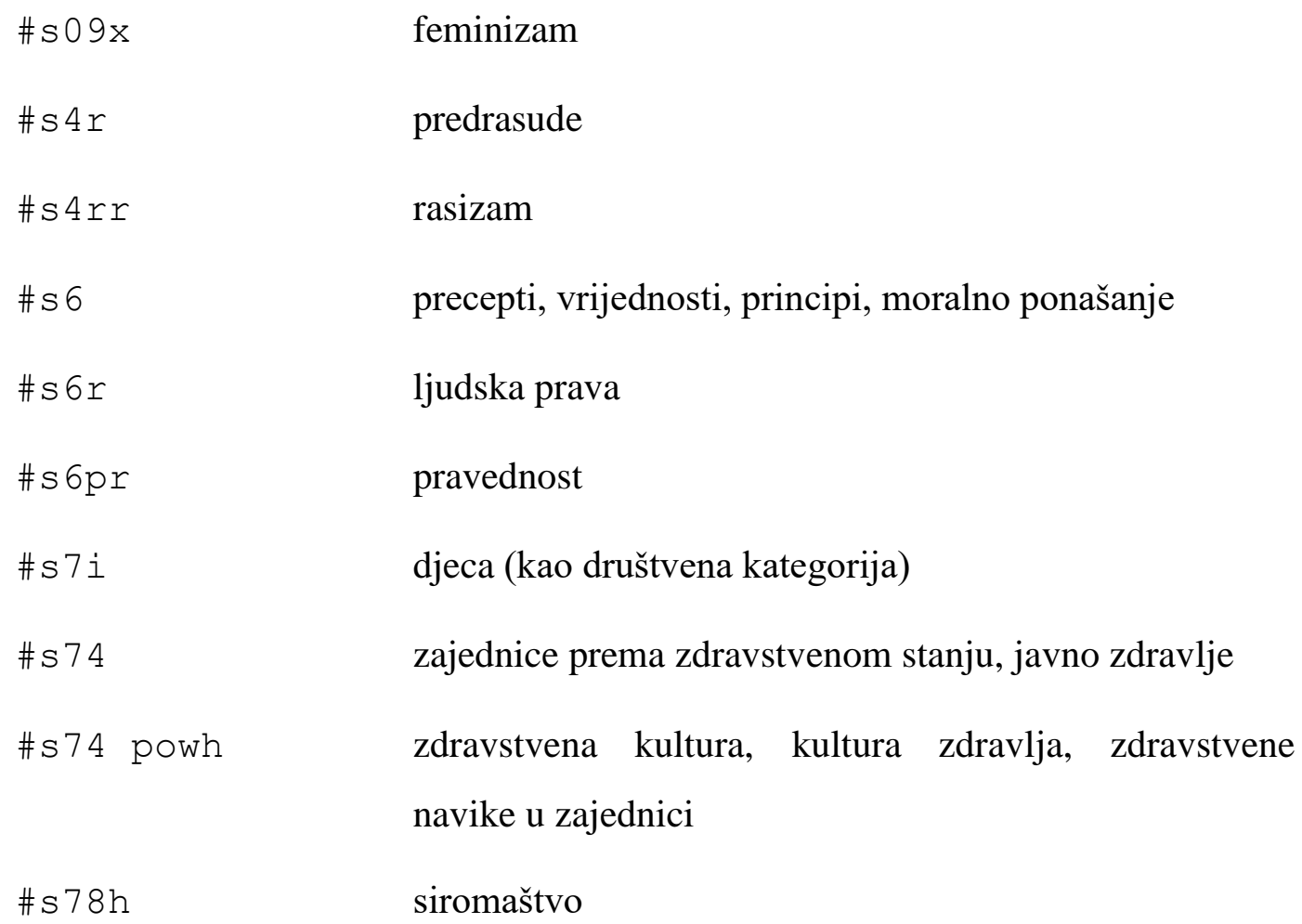




$\begin{array}{ll}\text { \#s87f } & \text { manjinske populacije } \\ \text { \#s95 } & \text { etnicitet } \\ \text { \#s090rt } & \text { religijske zajednice } \\ \text { \#sop9ve5c } & \text { enviromentalizam, ekološki društveni pokreti } \\ \text { \#sop9ve5c y67y } & \text { enviromentalizam, holistički }\end{array}$

Posebnu pozornost traži klasa \#s6 koja se odnosi na etičke precepte. Klasifikacija integrativnih razina enumerira različite vrste vrijednosti, principa, konvencija, normi, vrlina, odnosa i vrsta moralnog ponašanja. Uza sve njih identificirano je da klasifikacija ne modelira koncepte poput suosjećanja, prijateljstva, odgovornosti, senzibiliteta, dužnosti, zlatnog pravila, imperativa, dostojanstva, ranjivosti, integriteta i neškodljivosti. Na razini individualne moralne svijesti klasifikacija navodi utilitarističku orijentaciju i orijentaciju na univerzalne etičke principe. Neke od spomenutih koncepata koji nedostaju moglo bi se do određene mjere izraziti kombinacijom klasa, no njihov nedostatak jedina je ozbiljna prepreka za primjenu Klasifikacije integrativnih razina u području integrativne bioetike. Sve ove klase moglo bi se dapače osmisliti u okviru lokalnih primjena klasifikacije, no riječ je o općenitim konceptima koji će biti razmotreni za uključivanje na temeljima ove analize te predstavljaju mogući doprinos razvoju Klasifikacije integrativnih razina.

\section{Politički uređenja \#t}

U području kao dio centralne teme jednog dokumenta nalazimo samo demokraciju \#t 6 r kao referencirano političko uređenje. Posebni oblik deliberacije koje obuhvaća ova klasa jesu etički komiteti koje možemo označiti kao:

$$
\begin{array}{ll}
\text { \#t7ec9yshr } & \text { etički komiteti } \\
\# \text { t7ec9B } & \text { bioetički komiteti }
\end{array}
$$

\section{Pravni entiteti \#u}

U kontekstu prava i pravnih entiteta fasete koje određuju njihov domet može se definirati internacionalna tj. globalna orijentacija, no za sam proces globalizacije koji je umjereno relevantna tema za analizirano područje nije predviđena zasebna klasa. Na ovoj se integrativnoj razini enumeriraju vrste prava i pravnih odnosa. Identificirane teme:

$$
\text { \# u } 5 \mathrm{k} \quad \text { tržište }
$$




$\begin{array}{ll}\# u 6 \text { B } & \text { bioetički relevantni zakoni } \\ \# u 6 \mathrm{kWn} & \text { biopravo, pravne regulacije u odnosu na život } \\ \# u 66 & \text { posjedovanje prava } \\ \# u 66 \mathrm{kWn} & \text { pravo na život } \\ \# u 7 d & \text { prirodi resursi, obradiva zemlja } \\ \# u 7 d 07 \mathrm{hr} & \text { etika zemlje } \\ \# u \circ & \text { korporacije }\end{array}$

\section{Djelatnosti \#v}

Prilozi razmatraju sljedeće vrste djelatnosti:

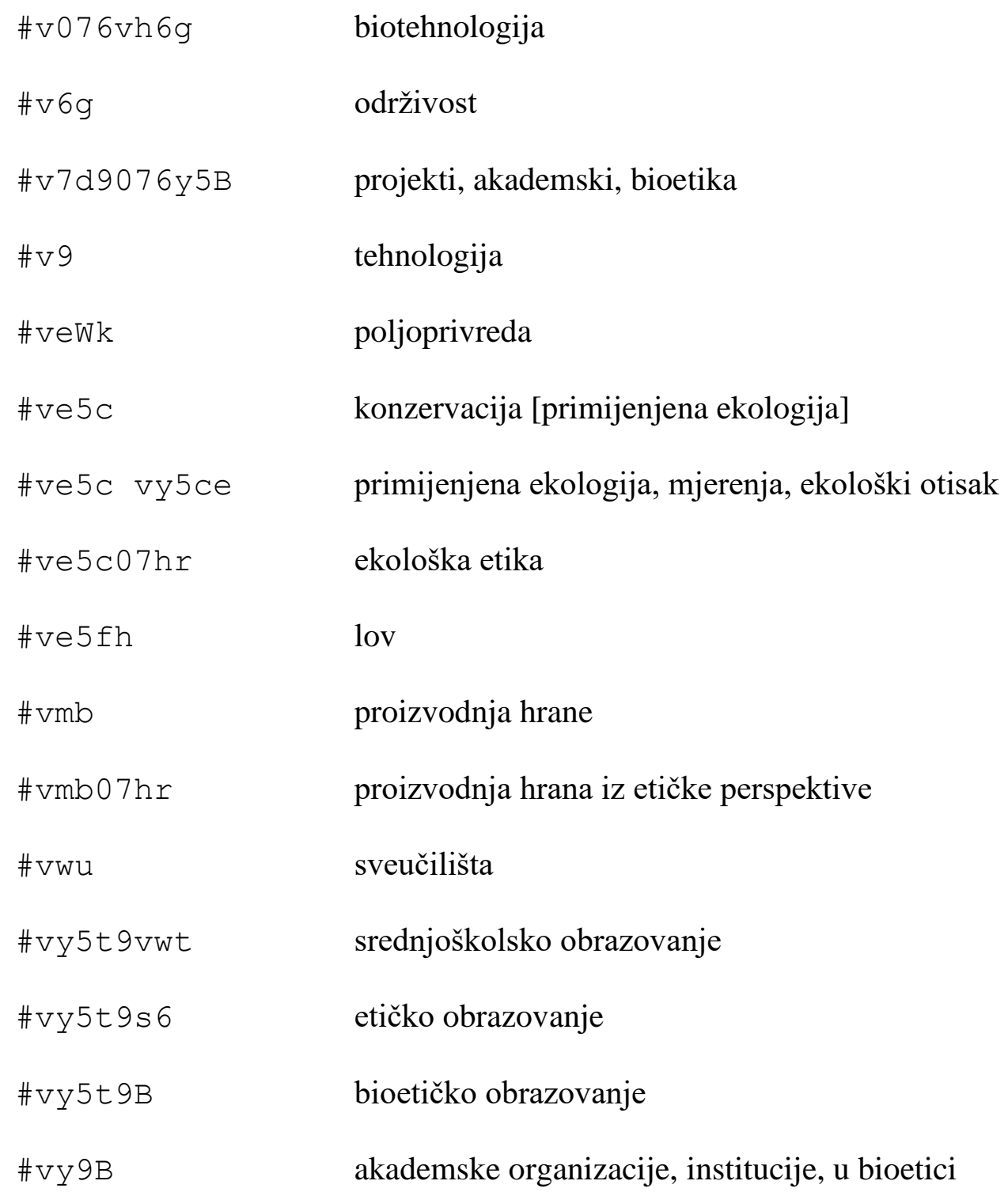


U kontekstu određenja medicinske etike može se zamijetiti potreba razlikovanja medicinske etike od kliničke etike koju se u kontekstu klasifikacije integrativnih razina može razlikovati jedino ako se notaciji koja označava medicinsku etiku \#vuh07hr pridoda oznaka za klinike kao mjesta pružanja zdravstvene zaštite čineći tako \#vuh2Ci07hr. S obzirom na to da je zdravstvena zaštita kao vrsta djelatnosti nadređena samom pružanju medicinske skrbi u analiziranom setu moguće je oblikovati sljedeću hijerarhiju fenomena:

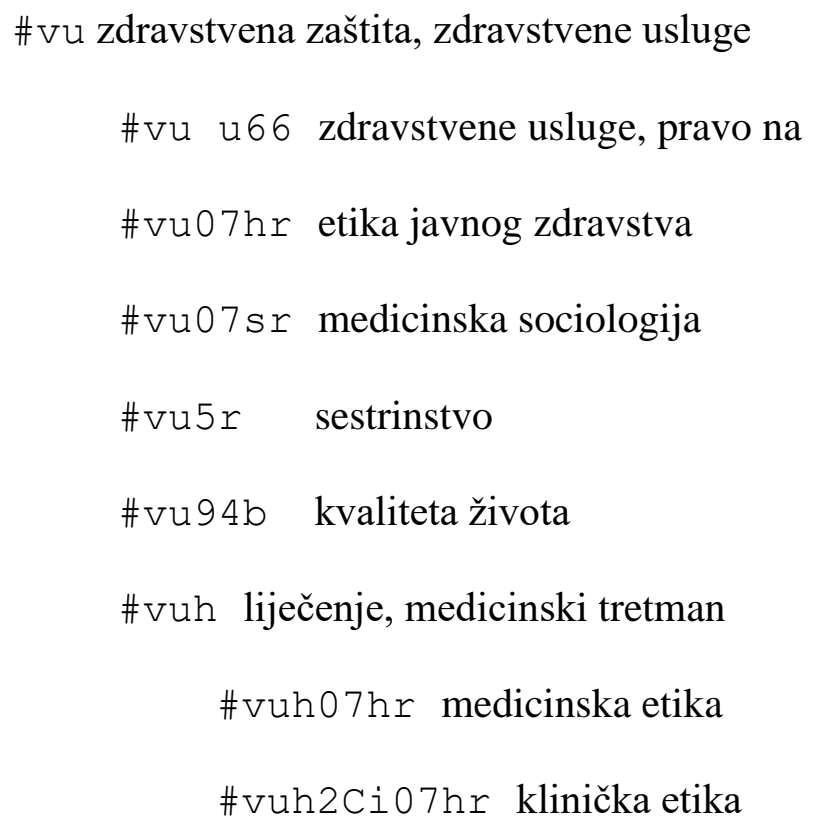

\section{Artefakti \#w}

Za razliku od samih djelatnosti koje ih mogu produciraju, artefakti sami tj. entiteti ljudskog porijekla rijetko su centralni interes radova u području integrativne bioetike. Identificirani su interesi poput:

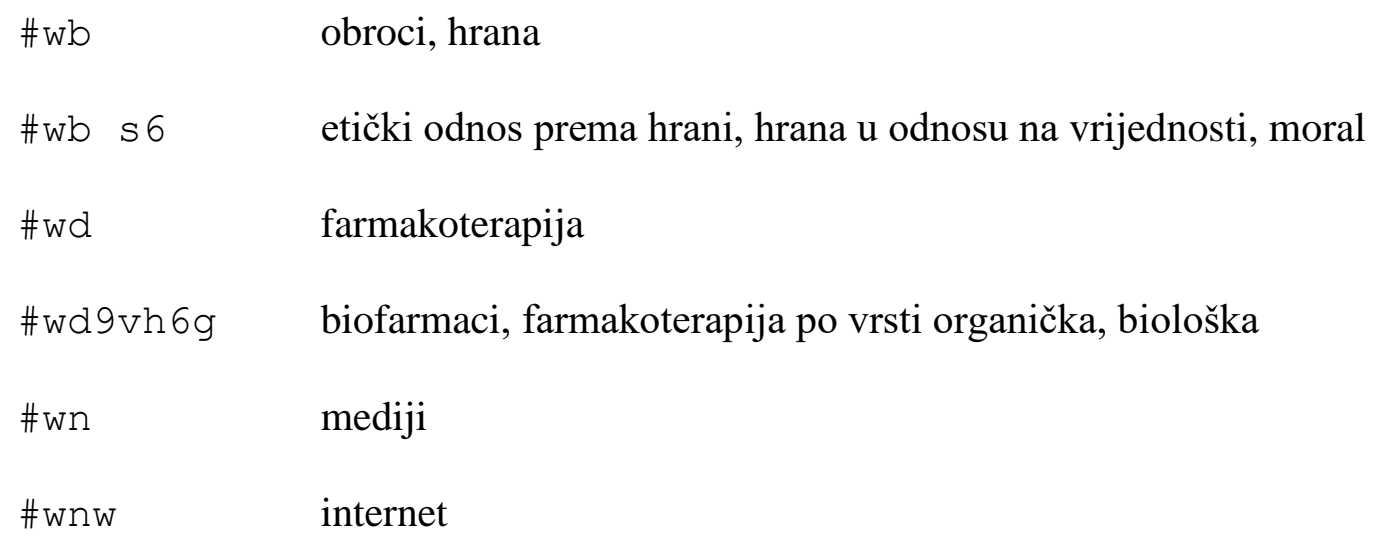

\section{Umjetnine, kreativna djela \# $x$}

Kao vrsta kreativnog izričaja u deset dokumenata sport čini centralnu temu, a uz njega razmatrana je i arhitektura u odnosu spram bioetike. 


$\begin{array}{ll}\# \text { \#97s } & \text { arhitektura } \\ \# x v & \text { sport } \\ \# \text { xv07B } & \text { bioetika sporta } \\ \text { \#xv07sr } & \text { sociologija sporta } \\ \text { \#xwts } & \text { nogomet }\end{array}$

\section{Znanje \#y}

Posljednja klasa, najviša razina integracije u Klasifikaciji integrativnih razina, rezervirana je za razinu znanja. Ova klasa predviđa klase za različite karakteristike zabilježenog znanja, srodne koncepte te donosi popis disciplina kojima se uređuju sve disciplinarne perspektive.

$\begin{array}{ll}\text { \#у6cx } & \text { bibliografija, zabilježeno u } \\ \text { \#y86 } & \text { istinitost } \\ \text { \#y8v } & \text { stručnost } \\ \text { \#ysh } & \text { filozofija } \\ \text { \#ysh009s7iWl } & \text { filozofija za djecu i mlade } \\ \text { \#ysh9Dmn } & \text { utilitarizam } \\ \text { \#yshr } & \text { etika } \\ \text { \#yshr076 } & \text { primijenjena etika } \\ \text { \#yst } & \text { tehnika [primijenjene znanosti] } \\ \text { \#yst90k } & \text { genetičko inženjerstvo } \\ \text { \#yss } 1 & \text { biologija } \\ \text { \#ysslg } & \text { genetika } \\ \text { \#ysslv } & \text { evolucijska biologija } \\ \text { \#yssr } & \text { sociologija } \\ \text { \#yxs } & \text { klasifikacija }\end{array}$

Navodimo i nekoliko složenih klasa odredivih na ovoj razini integracije:
$\# \mathrm{y} 42 \mathrm{mU}$
antropocentrizam 
\#y90mq7n07hr neuroetika

Kod disciplinarnih perspektiva na ovoj razini integracije razvidno je prikazano kako će djela koja se odnose na posebne dijelove nekog fenomena biti hijerarhijski uređena. Neuroetika se klasificira kao etika neuroznanosti tj. centralni fenomen kojim se ta etika bavi nije živčani sustav kao dio nekog organizma, već znanost koja se bavim živčanim sustavom. Zbog toga neuroetika nužno mora imati svoje mjesto pri samom vrhu integrativnih razina jer je riječ o etici neke znanosti, a ne o etici njenih fenomena.

Konačno, zamijećeno je da pojam epohe nije moguće klasificirati u smislu u kojem je prezentiran u literaturi. Naime, Čović (2006) govori o prijelomu epohe i tzv. tehnoznanstvenoj epohi. Klasifikacija integrativnih razina historijske periode tretira u kronološkom smislu pri čemu se traži konkretno ili približno određenje početka i kraja neke epohe. Epohu tehnoznanosti nije moguće odrediti u takvom smislu. S druge strane klasifikacija nudi mogućnost određenja pojedinih razdoblja civilizacijske povijesti, pa tako nakon nudi mogućnost klasificiranja djela kao pripadna opisno, informacijskom dobu, no ni to određenje ne poklapa se s opsegom značenja tehno-znanstvene epohe. Odnos tehnologije i znanosti treba se stoga klasificirati inkluzivno kao opći odnos bez temporalnih referenata.

\#v9 ys tehnologija i znanost u odnosu 


\section{Perspektive}

Preostaje prikazati kako se na temelju Klasifikacije integrativnih razina mogu strukturirati perspektive koje sudjeluju u karakterizaciji bioetički relevantnih fenomena, a koje su zamijećene $u$ analiziranom setu literature iz područja integrativne bioetike. Perspektive se navode prema slobodno definiranim kategorijama koje u načelu prate pojedinu kategoriju faseta Klasifikacije integrativnih razina.

\section{Kulturne i povijesne regije}

Klasifikacija omogućuje detaljnu karakterizaciju fenomena prema kulturnim i povijesnim regijama na koje se odnosi. Ove se fasete ne odnose na aktualne geo-političke podijele svijeta već na one relevantne kulturne regije i političke podjele svijeta koje za određena razdoblja povijesti definira povijesna znanost.

$\begin{array}{ll}\text { \#02g91pxx } & \text { kao što je poznato u regiji Ruske Federacije } \\ \text { \#02iWl } & \text { kao što je poznato u afričkim državama } \\ \text { \#029i } & \text { kao što je bilo poznato u kulturi Antičke Indije } \\ \text { \#029k } & \text { kao što je bilo poznato u kulturi istočnih azijskih civilizacija } \\ \text { \#029kc } & \text { kao što je bilo poznato u kulturi kineske civilizacije } \\ \text { \#029r } & \text { kao što je bilo poznato u kulturi mediteranskih civilizacija } \\ \text { \#029rh } & \text { kao što je bilo poznato u kulturi helenske civilizacije } \\ \text { \#029s c } & \text { kao što je bilo poznato u kulturi islamskog zlatnog doba 800-1258 NE } \\ \text { \#029w } & \text { kao što je bilo poznato u kulturi moderne zapadne civilizacije }\end{array}$

\section{Metode i retoričke strategije}

$\mathrm{Na}$ razini retoričkih strategija pronađena je samo jedna relevantna perspektiva koja se odnosi na stil pisanja radova koji kompariraju radove različitih autora, koji fenomene sagledavaju u komparaciji podneblja ili regija koje ih karakteriziraju itsl. Stoga, \#-0 059qtm komparativni stil primjer je retoričke strategije identificiran u devet dokumenata iz analiziranog seta.

Na razini metoda najprepoznatljivije su vrste srodne filozofskom mišljenju poput:

$\begin{array}{ll}\# \text { 03c } & \text { konceptualizacije } \\ \# 03 i & \text { rasprave }\end{array}$


\#03r kritički osvrti

\section{Razmatranje fenomena iz perspektive pristupa pojedinog autora}

Literaturu u analiziranom setu posebno karakterizira jedan specifičan set perspektiva. Naime, mnogi radovi neki fenomen razmatraju u odnosu na rad, filozofiju ili pristup nekog autora \#063 kao što je poznato s obzirom na autora. Najčešći autori koji su u tom smislu interesantni autorima priloga u području integrativne bioetike jesu Immanuel Kant, Fritz Jahr i Van Rensselaer Potter.

\section{Disciplinarne perspektive}

Kada govorimo o disciplinarnim perspektivama u području integrativne bioetike identificiran je set filozofskih, bioloških, medicinskih i socioloških perspektiva što se poklapa $s$ predstavljenim definicijama područja. Filozofske perspektive mogu se dalje specificirati zamijećenim referencama na pojedine filozofske škole i pristupe:

\begin{tabular}{|c|c|}
\hline \#07c & kao što se razmatra u, kozmologija \\
\hline \#07h & kao što se razmatra $u$, filozofija \\
\hline \#07h9Dge & kao što se razmatra u, pre-sokratička filozofija \\
\hline \#07h9Dgg & kao što se razmatra $u$, pitagoreanizam \\
\hline \#07h9Dmi & kao što se razmatra $u$, njemački idealizam \\
\hline \#07h90A & kao što se razmatra u, filozofija svijeta \\
\hline \#07h90y & kao što se razmatra $u$, filozofija znanosti \\
\hline \#07h90p & kao što se razmatra $u$, filozofija psihe \\
\hline \#07he & kao što se razmatra u, epistemologija \\
\hline \#07hr & kao što se razmatra $u$, etika \\
\hline \#07hr90vu5r & kao što se razmatra $u$, etika sestrinstva \\
\hline \#07sl & kao što se razmatra $u$, biologija \\
\hline \#07sx & kao što se razmatra $u$, kulturna antropologija \\
\hline \#07te & kao što se razmatra $u$, medicina \\
\hline
\end{tabular}


Primjer etike sestrinstva pokazuje kako se perspektiva filozofske etike može dalje odrediti s obzirom na perspektive koje se odnose na kontekst specifičnih djelatnosti, područja djelovanja.

Za razliku od toga klasifikacija predviđa i perspektive koje se općenito odnose na primjenu nekog fenomena u kontekstu specifičnih djelatnosti:

$\begin{array}{ll}\text { \#076e5c } & \text { primijenjeno u prezervacijskom, ekološkom kontekstu } \\ \text { \#076u } & \text { primijenjeno u kontekstu zdravstva } \\ \text { \#076u5r } & \text { primijenjeno u kontekstu sestrinstva } \\ \text { \#076um } & \text { primijenjeno u kontekstu kliničke medicine }\end{array}$

Kada bismo bioetiku odredili deiktički, bioetička perspektiva bila bi iskazana klasom \#-07B.

\section{Normativne perspektive}

Klasifikacija integrativnih razina predviđa nekoliko faseta kojima se uređuje odnos između fenomena u normativnom smislu i to najčešće kao vrstu svojstva ili kvalitete:

$\begin{array}{ll}\text { \#64 } & \text { u neskladu s normom, obvezom, standardom } \\ \text { \#66 } & \text { u skladu s normom, obvezom, standardom } \\ \# 9 s 6 & \text { moralno } \\ \# 90 s 6 & \text { koje se odnosi na fenomen morala }\end{array}$

\section{Društveno-političke perspektive}

Razne društveno-političke perspektive modelirane su na integrativnim razinama na koje se odnose kao specifične teorije. Njihove klase može se dodatno fasetno tretirati u odnosu s drugim fenomenima. Na sličan način na razini djelovanja primijenjene ekologije Klasifikaciju integrativnih razina trebalo bi proširiti environmentalističkim pristupima koji trenutno nisu izrazivi u ovome smislu. Ove se specifični teorijski nazori mogu tretirati kao svjetonazori pod:

$\begin{array}{ll}\text { \#069s09x } & \text { prema svjetonazoru, feminizam } \\ \text { \#069t09i } & \text { prema svjetonazoru, liberalizam }\end{array}$


Kako bi razlikovala primjerice školovanje od obrazovanja Klasifikacija integrativnih razina predviđa i klase koje se odnose na neke opće društvene procese, pa tako u analiziranom setu identificiramo:

$$
\begin{array}{ll}
\text { \#0760t } & \text { primijenjeno na, politika } \\
\text { \#0760u } & \text { primijenjeno na, ekonomija } \\
\text { \#0760yae } & \text { primijenjeno na, obrazovanje }
\end{array}
$$

\section{Religijske perspektive}

Religijske perspektive zamijećene su u 27 analiziranih dokumenata. Primjenjivi kodovi koji označavaju opću i specifičnu razinu religijskih perspektiva sljedeći su:

$\begin{array}{ll}\text { \#0733 } & \text { u odnosu na zajednicu prema religijskoj pripadnosti } \\ \text { \#0733t } & \text { u odnosu na religijsku zajednicu, kršćanstvo } \\ \text { \#0733td } & \text { u odnosu na religijsku zajednicu, ortodoksija } \\ \text { \#0733th } & \text { u odnosu na religijsku zajednicu, katoličanstvo } \\ \text { \#0733u } & \text { u odnosu na religijsku zajednicu, islam }\end{array}$

\section{Temporalni referenti}

Pristup znanju u području integrativne bioetike može se osigurati i nizom temporalnih referenata. Naime, brojni radovi osvrću se na filozofski rad autora poput Fritza Jahra ili Vana Rensselaera Pottera. Vremenski rasponi koje obujmljuju njihovi životi ili godišta objave seminalnih djela često se koriste za periodizaciju razvoja bioetike, stoga bi se korisnim mogle pokazati fasete koje kronološki određuju važne momente u području poput:
\#131971 1971., godina objave djela Bioethics: Bridge to the Future Vana Rensselaera Pottera
\#131895 1895., godina rođenja Fritza Jahra

Izrazito dominantan istraživački interes u području jesu analize povijesti bioetike koje bi se trebalo okupiti pod općom oznakom za sve vrste povijesnih perspektiva \#01 pri čemu je poželjno radove diferencirati razvojem oznaka za specifične povijesne periode na koje se odnose po uzoru na prethodno predstavljeni princip. 


\section{Geografski referenti}

Kada govorimo o aktualnoj geo-političkoj podijeli svijeta moguće je uočiti da se literaturu može klasificirati fasetama podudarnim $\mathrm{s}$ geografskim referentima identificiranim $u$ bibliometrijskom dijelu analize područja integrativne bioetike.

$\begin{array}{ll}\# 23 \mathrm{f} & \text { Sjeverna Amerika } \\ \# 23 j \circ W y & \text { Azija } \\ \# 23 j \mathrm{dWm} & \text { Europa } \\ \# 27 \mathrm{fzk} & \text { Hrvatska } \\ \# 27 \mathrm{fzl} & \text { Bosna i Hercegovina } \\ \# 27 \mathrm{fm} & \text { Srbija } \\ \# 27 \mathrm{fzv} & \text { Ukrajina } \\ \# 27 \mathrm{fzq} & \text { Sjeverna Makedonija } \\ \# 27 \mathrm{fzs} & \text { Bugarska } \\ \# 27 \mathrm{fzkWv} & \text { zadani raspon jugoistočno europskih zemalja }\end{array}$




\section{ZAKLJUČAK}

Važnost razvoja interdisciplinarnih i transdisciplinarnih klasifikacija postaje jasna kada je sagledamo u uvjetima sve značajnije specijalizacije znanstvenog znanja s kojom dolazi i do izrazite specijalizacije jezika kojim se barata u pojedinom području. Znanstvenici koji se bave istim fenomenima, ili različitim aspektima istog fenomena, ne mogu kvalitetno komunicirati zbog jezičnih barijera. Stoga, potrebna su nam nova pomagala koja će ponovno unificirati razlomljeno znanje. To je još više relevantno u transdisciplinarnom kontekstu kada se poslanje osiguranja predmetnog pristupa dodatno usložnjava te nam je za uspješan prijevod i prijenos ideja i mišljenja potrebna pomoć u vidu putokaza koji će nas voditi kroz rastuću kompleksnost i raznolikost perspektiva prema momentima koji naglašavaju sličnost njihovih osnova.

Ova disertacija pokazala je kako je povijest klasifikacije i sustava za organizaciju znanja podržavala monoperspektivistički i na znanstvene discipline orijentirani pogled na svijet. Za razumijevanje koncepta jamstva perspektiva bilo je potrebno objasniti ulogu engleske zajednice znanstvenika tj. Radne grupe za klasifikacijska istraživanja (engl. Classification Research Group i.e. CRG) koja je začela kritičko razmatranje tradicionalnih klasifikacijskih sustava i udarila temelje kritici disciplinarnog utemeljenja sustava za organizaciju znanja i alternativi tom pristupu tj. klasifikaciji fenomena. Devedesetih godina prošlog stoljeća organizacija znanja konstituira se kao novo područje znanstvenog interesa. S promjenom interesa, dolazi i do postepene promjene paradigme u novoimenovanom području organizacije znanja tj. dolazi do post-modernističkog zaokreta i inovacije analize domene. Taj pogled na organizaciju znanja doživio je brojne kritike, pa čak i došao u opasnost da organizaciju znanja pretvori u potpuno relativistički pristup prema kojem nije moguće znanje percipirati kao međusobno povezano. Interdisciplinarna i transdisciplinarna organizacija znanja, koja je svoje najbolje ostvarenje doživjela u projektima poput Klasifikacije integrativnih razina, nudi trenutno najsofisticiraniji pristup za suočavanje s navedenim problemima znanosti jer uključuje pouke i klasifikacijske postupke iz čitave povijesti područja organizacije znanja te dovodi do revitalizacije napuštenih univerzalističkih aspiracija u klasifikaciji. Ona predstavlja projekt izgradnje nove opće klasifikacijske sheme koja bi ovaj puta bila utemeljena kao klasifikacija fenomena. Istraživanjem se nastoji premostiti problem osiguranja predmetnog pristupa akademskim i neakademskim izvorima informacija u inter- i transdisciplinarnom kontekstu. 
Znanstveni doprinosi koji su ostvareni doktorskim radom odnose se na izgradnju osnove primjenjivog sustava za organizaciju znanja u području integrativne bioetike, domenskoanalitičko konstituiranje domene integrativne bioetike kao stabilnog i produktivnog područja znanstvenog interesa, produbljivanje artikulirane kritike disciplinarnog poimanja organizacije znanja i teorijskih polazišta transdisciplinarne organizacije znanja te inovativnu implementaciju postavki klasifikacije integrativnih razina u metodološki obrazac za analizu sadržaja u nekoj domeni znanja koja je primjenjiva i na druge domene znanja.

U doktorskom radu provedeno je istraživanje prema metodološkom obrascu analize domene koji uključuje bibliometrijsko istraživanje i analizu sadržaja izvora iz područja integrativne bioetike. Analizu domene kombinacijom metoda bibliometrije i analize sadržaja primijenjenu su kako bi se ostvario doprinos teorija o tome kako klasificirati u interdisciplinarno i transdisciplinarno orijentiranim područjima znanja poput integrativne bioetike. Bibliometrijsko istraživanje konstituira domenu integrativne bioetike kao primjer interdisciplinarno i transdisciplinarno orijentiranog područja koje oblikuje specifičan zahtjev za pluriperspektivnom organizacijom znanja. Analiza sadržaja iskorištena je kako bi se odgovorilo na tu potrebu te je stvorena osnova za izgradnju sustava za organizaciju znanja u području integrativne bioetike.

Analiza sadržaja usmjerena na otkrivanje centralnih tema pojedinoga priloga predstavlja simulaciju stručnog postupka koji se u ovom istraživanju obuhvatno primjenjuje na uzorak literature koji adekvatno odražava područje integrativne bioetike. Time je osigurano da procjena primjenjivosti Klasifikacije integrativnih razina odražava onu razinu klasifikacijskog rada kakav bi se mogao očekivati u stvarnom praktičkom kontekstu. Problem fokusa na disciplinarni pogled na svijet u praksi klasifikacije očituje se kao tretman uspostavljenih shema u formi propisa i pravila, kao jedini valjani pristup i vid organizacije univerzuma znanja. Kao konačan i točan uzima se arbitrarni vid svake od pojedinih reprezentiranih disciplina i to u onom opsegu u kojem su ga izrađivači klasifikacije uspjeli reprezentirati. Ta kritika i prikazane aktualne prakse osiguranja predmetnog pristupa u području bioetike impliciraju da je klasifikacija u praksi postala nereflektirani mehanički proces u kojem klasifikatori često primijenjuju kratice i prečace utemeljene u navikama disciplinarnog mišljenja. Problem se usložnjava kada se ne razmatra i sama pozicija u klasifikacijskoj shemi koja je nekoj klasi dodijeljena pa se onda tretira kao da ne podrazumijeva epistemološke pretpostavke toga smještaja (npr. bioetika definirana u kontekstu biotehnologije uzima se kao bioetika u svim kontekstima). No, nereflektirana klasifikacija nije rezervirana samo za 
disciplinarne klasifikacije. Taj isti problem može zadesiti i klasifikaciju integrativnih razina u fazi njene primjene. Klasifikatori u području integrativne bioetike imaju priliku osiguranju predmetnog pristupa svojoj građi pristupiti izrazito pluriperspektivno, transdisciplinarno i u konačnici integrativno. Upravo bi se u reprezentaciji znanja mogli odražavati rezultati dijaloškog procesa interakcije perspektiva jer će klasifikator prateći razvoj rasprave reprezentaciju domene obogaćivati nizom izvanznanstvenih i izvanakademskih izvora znanja. Time će svaki snimak okruglog stola, email korespondencija s civilnim sektorom, audio zapis predavanja, itd. postati dokument koji, arhiviran, čini nepresušan izvor informacija o gledištima izvanznanstvenih društvenih aktera. Klasifikator svojim metodama, kumulativno i iterativno, poduprt analizom domene, kvantitativno i kvalitativno, bilježi opisuje i reflektira nad izvorom informacija o gledištu i time omogućava pluriperspektivnu reprezentaciju znanja.

Implementacijom postavki klasifikacije integrativnih razina u metodološki obrazac za analizu sadržaja pokazano je da domena integrativne bioetike nije kategorički zatvorena domena tj. da inkorporira i bavi se entitetima različitih razina integracije, što znači da se suočava i s različitim logikama njihove organizacije. Identificirano je da su jedina prepreka reprezentaciji znanja klasifikacijom fenomena $u$ području integrativne bioetike tek manji nedostaci $u$ ekspresivnosti Klasifikacije integrativnih razina koji se mogu razriješiti u lokalnoj aplikaciji ili formiranjem prijedloga za unapređenje same opće sheme. Klasifikacija je na svim drugim razinama ekspresivnija i preciznija od postojećih rješenja za osiguranje predmetnog pristupa u području bioetike prvenstveno zbog toga što omogućava smještaj tematike interdisciplinarnog područja znanja u opću sistematiku fenomena kojom se premošćuju disciplinarne razlike. Njena totalna aspektnost i princip slobodne fasetizacije omogućuju obuhvatni prikaz složenosti svjetonazora kakav je nužan za kvalitetno osiguranje predmetnog pristupa u kontekstu šire bioetičke rasprave u kojoj su pozvani sudjelovati i sudjeluju akteri svih slojeva i naličja društvenih zajednica.

U kontekstu odgovora na temeljno pitanje ovog doktorskog rada, a to je ono o samoj definiciji jamstva perspektive u transdisciplinarnoj organizaciji znanja pojašnjeno je da se u području organizacije znanja pristupi transdisciplinarnoj organizaciji znanja supsumiraju pod interdisciplinarnu organizaciju znanja polazeći od pretpostavke o jedinstvu svih stvari koje je moguće reprezentirati samo ako napustimo klasifikacijske prakse koje unaprijed preferiraju određene disciplinarne perspektive te discipline same kao osnovu za organizaciju znanja. Transdisciplinarno znanje jedino je smisleno integrativno reprezentirati u kontekstu 
univerzalnih sustava za organizaciju znanja. Bez obzira na to je li riječ o transdisciplinarnosti potaknutoj u akademskom miljeu ili građanskoj transdisciplinarnosti. Potrebe tražitelja znanja i informacija u transdisciplinarnom kontekstu moći će biti podržane samo ako se polazi o pretpostavke o jedinstvu sveg znanja. Zasnivanjem klasifikacije fenomena u teoriji integrativnih razina osigurana je ona vrsta vizije transdisciplinarnosti kakvu Basarab Nicolescu (1994) traži u drugom članku proklamacije o transdisciplinarnosti koji se odnosi na prihvaćanje ideje o postojanju različitih razina stvarnosti kojima upravljaju različite vrste logike kao i pozicije da stvarnost nije svodiva na jednu od tih razina ili njenu logiku. Slijedom tih teorijskih određenja transdisciplinarnosti i potreba koje proizlaze iz definicije transdisciplinarnog rada $u$ području integrativne bioetike $i$ kulturnih perspektiva izvanznanstvenih aktera znanje se u domeni integrativne bioetike mora organizirati koristeći one sustave i organizacijske principe koji će u perspektivi budućeg razvoja područja omogućiti što sustavniju reprezentaciju kompleksnosti jedinstva sveg znanja čiji se aspekti mogu preklapati pa čak i na razini spoznajnih perspektiva biti međusobno kontradiktorni. Drugim riječima jamstvo perspektive u transdisciplinarnoj organizaciji znanja postiže se reprezentacijom te kompleksnosti kao pluriperspektivnog jedinstva sveg znanja. 


\section{POPIS LITERATURE}

1. Adler, N. J., \& Harzing, A.-W. (2009). When knowledge wins : transcending the sense and nonsense of academic rankings. Academy of Management Learning \& Education, $8(1)$, str. 72-95.

2. Albrechtsen, H. (2015). This is not domain analysis. Knowledge Organization. 42 (8), str. 557-561.

3. Andres, A. (2009). Measuring academic research : how to undertake a bibliometric study. Amsterdam [etc.] : Chandos.

4. Arboit, A. E. (2018). Knowledge organization from terms to concepts from concepts to domains. Knowledge Organization, 45 (2), str. 125-136.

5. Austin, D. (1974). Progress in documentation: the development of PRECIS: a theoretical and technical history. Journal of Documentation, 30 (1), str. 47-102.

6. Barité, M. (2018). Literary warrant. Knowledge Organization, 45 (6), str. 517-536.

7. BARTOC. (2021). Dictionary of clinical drugs. URL: http://bartoc.org/en/node/1572\#about (4.12.2021.).

8. Beghtol, C. (1986a). Bibliographic classification theory and text linguistics : aboutness analysis, intertextuality and the cognitive act of classifying documents. Journal of Documentation, 42 (2), str. 84-113.

9. Beghtol, C. (1986b). Semantic validity : Concepts of warrant in bibliographic classification systems. Library Resources \& Technical Services, 30 (2), str. 109-125.

10. Beghtol, C. (1998). General classification systems : principles for multidisciplinary specification. Advances in Knowledge Organization, 6, str. 89-96.

11. Beghtol, C. (2002a). A proposed ethical warrant for global knowledge representation and organization systems. Journal of Documentation, 58, 507-532.

12. Beghtol, C. (2002b). Universal concepts, cultural warrant, and cultural hospitality. Advances in Knowledge Organization, 8, str. 45-49.

13. Biagetti, M. T. (2021). Ontologies (as knowledge organization systems). U: Hjørland, B. \& Gnoli, C. (ur.) Encyclopedia of Knowledge Organization. ISKO. URL: https://www.isko.org/cyclo/ontologies (4.12.2021.).

14. BioethicsLine. (2021). URL: https://repository.library.georgetown.edu/handle/10822/ 713699

15. Broughton, V. (2002). Facet analytical theory as a basis for a knowledge organization tool in a subject portal. U: Challenges in Knowledge Representation and Organization 
for the 21st Century : Integration of Knowledge across Boundaries. Presented at the The Seventh International ISKO Conference, 1013 July 2002, Granada, Spain, Granada. Baden-Baden : Nomos Verlagsgesellschaft. Str. 135-142.

16. Cameron, F., Mengler, S. (2009). Complexity, transdisciplinarity and museum collections documentation : emergent metaphors for a complex world. Journal of Material Culture, 14, str. 189-218.

17. Chaturbhuj, S. B. \& Batcha M. S. (2020). Application of Lotka's Law to the research productivity in the field of Thermodynamics during 2015-2019. Library Philosophy and Practice (e-journal). 4523.

18. Classification Research Group. (1955a). CRG Bulletin. Library Association Record, 57, str. 262.

19. Classification Research Group. (1955b). The need for a faceted classification as the basis of all methods of information. Library Association Record, 57 (7) str. 262-268.

20. Classification Research Group. (1956). Bibliography of papers on classification and allied subjects. Journal of Documentation, 12 (4), str. 227-330.

21. Classification Research Group. (1957). Classification Research Group Bulletin No. 4. Journal of Documentation, 14 (3), str. 136-143.

22. Classification Research Group. (1958). Classification Research Group Bulletin No. 5. Journal of Documentation, 15 (1), str. 39-57.

23. Classification Research Group. (1961). Classification Research Group Bulletin No. 6. Journal of Documentation, 17 (2), str. 156-172.

24. Classification Research Group. (1962). Classification Research Group Bulletin No. 7. Journal of Documentation, 18 (2), str. 65-88.

25. Classification Research Group. (1964). Classification Research Group Bulletin No. 8. Journal of Documentation, 20 (3), str. 146-169.

26. Classification Research Group. (1968). Classification Research Group Bulletin No. 9. Journal of Documentation, 24 (4), str. 273-298.

27. Classification Research Group. (1973). Classification Research Group Bulletin No. 10. Journal of Documentation, 29 (1), str. 51-68.

28. Classification Research Group. (1978). Classification Research Group Bulletin No. 11. Journal of Documentation, 34 (1), str. 21-50.

29. Classification Research Group. (1985). Classification Research Group Bulletin No. 12. Journal of Documentation, 41 (2), str. 75-99. 
30. Cleverdon, C. (1960). The ASLIB Cranfield research project on the comparative efficiency of indexing systems. Aslib Proceedings, 12 (12), str. 421-431.

31. Coates, E. J. (1988). The role of classification in information retrieval : action and thought in the contribution of Brian Vickery. Journal of Documentation, 44 (3), str. 216-225.

32. Čović, A. (2006). Pluralizam i pluriperspektivizam. Filozofska istraživanja, 26, str. 712.

33. Čović, A. (2007). Integrativna bioetika i pluriperspektivizam. U: Valjan, V. (ur.) Integrativna bioetika i izazovi suvremene civilizacije. Sarajevo : Bioetičko društvo u BiH. Str. 65-75.

34. Čović, A. (2011). Pojmovna razgraničenja: moral, etika, medicinska etika, bioetika, integrativna bioetika. U: Čović, A. \& Radonić, M. (ur.) Bioetika i dijete : Moralne dileme u pedijatriji. Zagreb: Pergamena : Hrvatsko društvo za preventivnu i socijalnu pedijatriju. Str. 11-24.

35. Dahlberg, I. (1971). Possibilities for a new universal decimal classification. Journal of Documentation, 27 (1), str. 18-36.

36. Dahlberg, I. (1975). The terminology of subject-fields. Knowledge Organization, 2 (1), str. 31-37.

37. Dahlberg, I. (1976). Classification theory, yesterday and today. Knowledge Organization, 3 (2), str. 85-90.

38. Dahlberg, I. (1988). The founding of the International Society for Knowledge Organization Frankfurt, 22 July 1989. Knowledge Organization, 16 (2), str. 71-72.

39. Dahlberg, I. (2006). Knowledge organization : a new science? Knowledge Organization, 33 (1), str. 11-19.

40. DRZE. (2021). Thesaurus Ethics in the Life Sciences. URL: https://www.drze.de/bioethics-thesaurus?set_language=en (4.12.2021.).

41. Farradane, J. (1961). Relational indexing. The Indexer, 2 (3), str. 95-98.

42. Farradane, J. (1967). Concept organization for information retrieval. Information Storage and Retrieval, 3 (4), str. 297-314.

43. Foskett, D. J. (1959). Comparative classification. Depth classification. Annals of Library and Information Studies (ALIS), 6 (4), str. 105-112.

44. Foskett, D. J. (1962). The Classification Research Group 1952-1962. Libri, 12 (2), str. $127-138$. 
45. Foskett, D. J. (1978). The theory of integrative levels and its relevance to the design of information systems. Aslib Proceedings, 30 (6), str. 202-208.

46. Foskett, D. J. (1980). Systems theory and its relevance to documentary classification. Knowledge Organization, 7 (1), str. 2-5.

47. Foskett, D. J. (1988). Brian Vickery : a personal memoir. Journal of Documentation, 44 (3), str. 199-204.

48. García Gutiérrez, A. (2011). Declassification in knowledge organization : a postepistemological essay. Transinformação, 23, str. 5-14.

49. García Gutiérrez, A. (2014). Declassifying Knowledge Organization. Knowledge Organization, 41 (5), str. 393-409.

50. Gillman, P. (1997). Thesauri to aid retrieval from very large text bases : subject term retrieval from large text resources, and the problems of ambiguity. U: McIlwaine, C. (ur.). Knowledge organization for information retrieval. Proceedings of the Sixth International Study Conference on Classification Research. Held at University College London, 16-18 June 1997. The Hague : International Federation for Information and Documentation. Str. 113-119.

51. Gnoli, C. \& Mei, H. (2006). Freely faceted classification for Web-based information retrieval. New Review of Hypermedia and Multimedia, 12 (1), str. 63-81.

52. Gnoli, C. (2004a). Naturalism vs. pragmatism in knowledge organization. Advances in Knowledge Organization, 9, str. 263-268.

53. Gnoli, C. (2007). Progress in synthetic classification : towards unique definition of concepts. Extensions and Corrections to the UDC, 29.

54. Gnoli, C. (2008a). Animals belonging to the emperor : enabling viewpoint warrant in classification. U: Landry, P., Bultrini, L., O'Neill, E. T., \% Roe, S. K. (ur.) Subject Access : Preparing for the Future, IFLA Series on Bibliographic Control. Berlin [etc.] : Walter de Gruyter. Str. 91-100.

55. Gnoli, C. (2008b). Ten long-term research questions in knowledge organization. Knowledge Organization, 35 (2/3), str. 137-149.

56. Gnoli, C. (2011). Ontological foundations in knowledge organization : the theory of integrative levels applied in citation order. Scire, 17 (1), str. 29-34.

57. Gnoli, C. (2012). Metadata about what? Distinguishing between ontic, epistemic, and documental dimensions in knowledge organization. Knowledge Organization, 39 (4), str. 268-275. 
58. Gnoli, C. (2016). Classifying phenomena Part 1 : Dimensions. Knowledge Organization, 43 (6), str. 403-415.

59. Gnoli, C. (2017a). Classifying phenomena Part 2 : Types and Levels. Knowledge Organization, 44 (1), str. 37-54.

60. Gnoli, C. (2017b). Classifying phenomena Part 3 : Facets. Draft chapter for the volume Dimensions of Knowledge. URL: https://www.gnoli.eu/class-phen3.rtf (25.5.2021.). [Manuscript].

61. Gnoli, C. (2018a). Classifying phenomena Part 4 : Themes and Rhemes. Knowledge Organization, 45 (1), str. 43-53.

62. Gnoli, C. (2018b). Mentefacts as a missing level in theory of information science. Journal of Documentation, 74 (6), str. 1226-1242.

63. Gnoli, C. (2019). Levels of information, and library and information science as a science of mentefacts. U: Proceedings of CoLIS, the Tenth International Conference on Conceptions of Library and Information Science, Ljubljana, Slovenia, June 16-19, 2019. Information Research, 24 (4), paper colis1903. URL: https://web.archive.org/web/20191216123153/http://informationr.net/ir/244/colis/colis1903.html (25.5.2021.).

64. Gnoli, C. et al (2011). Representing the structural elements of a freely faceted classification.

65. Gnoli, C., \& Ridi, C. (2014). Unified theory of information, hypertextuality and levels of reality. Journal of Documentation, 70 (3), str. 443-460.

66. Gnoli, C., \& Szostak, R. (2014). Universality is inescapable. 25th ASIS SIG/CR Classification Research Workshop. Advances in Classification Research Online. URL: https://journals.lib.washington.edu/index.php/acro/article/download/14906/12493 (25.5.2021.).

67. Gnoli, C., Bosch, M., \& Mazzochi, F. (2007). A new relationship for multidisciplinary knowledge organization systems : dependence. U: Rodriguez, B. \& Alvite Díez, M. L. (ur.) Actas Del VIII Congreso ISKO-España, León, 18, 19 Y 20 de Abril de 2007. Presented at the La interdisciplinariedad y la transdisciplinariedad en la organización del conocimiento científico : Interdisciplinarity and transdisciplinarity in the organization of scientific knowledge. León : Servicio de Publicaciones. Str. 399-410.

68. Gnoli., C., \& Poli, R. (2004b). Levels of reality and levels of representation. Knowledge Organization, 31 (3), str. 151-160. 
69. Harzing, A. W. (2007). Publish or Perish. URL: https://harzing.com/resources/publish-or-perish (25.5.2021.).

70. Harzing, A.-W., \& van der Wal, R. (2008). Google Scholar as a new source for citation analysis. Ethics in Science and Environmental Politics, 8 (1), str. 61-73.

71. Hjørland, B. (1992). The concept of 'subject' in information sciences. Journal of Documentation, 48 (2), str. 172-200.

72. Hjørland, B. (2002). Domain analysis in information science : eleven approaches traditional as well as innovative. JASIS, $58(4)$, str. 422-462.

73. Hjørland, B. (2003). Fundamentals of knowledge organization. Knowledge Organization, 30 (2), str. 87-111.

74. Hjørland, B. (2008). What is knowledge organization (KO)? Knowledge Organization, $35(2 / 3)$, str. 86-101.

75. Hjørland, B. (2015). Theories are knowledge organization systems (KOS). Knowledge Organization, 42 (2), str. 113-128.

76. Hjørland, B. (2018). The foundation of information science : one world or three? A discussion of Gnoli (2018). Journal of Documentation, 75 (1), str. 164-171.

77. Hjørland, B. (2021). User-based and cognitive approaches to knowledge organization. U: Hjørland, B. \& Gnoli, C. (ur.) Encyclopedia of Knowledge Organization. ISKO. URL: https://www.isko.org/cyclo/user_based (25.5.2021.).

78. Hjørland, B., \& Albrechtsen, H. (1995). Toward a new horizon in information science : domain-analysis. Journal of the American Society for Information Science, 46 (6), str. 400-425.

79. Hofkirchner, W. (2010). Twenty questions about a unified theory of information. A short exploration into information from a complex systems view. Litchfield Park, AZ : Emergent.

80. Horton, F. W. (2003). International Federation for Information and Documentation. U: Drake, M. A. (ur.) Encyclopedia of Library and Information Science. New York : Marcel Dekker Inc. Str. 1405-1407.

81. Ingwersen, P. \& Järvelin, K. (2005). The turn. Integration of information seeking and retrieval in context. Dordrecht: Springer.

82. ISKO. (2021). Integrative Levels Classification. URL: http://www.iskoi.org/ilc/ (25.5.2021). 
83. Jahina, R., Batcha, M. S. \& Ahmad, M. (2020). Lotka's Law and Pattern of Author Productivity in the Field of Brain Concussion Research: A Scientometric Analysis. Library Philosophy and Practice (e-journal). 4126.

84. Jurić, H. (2015). From the Notion of Life to an Ethics of Life. Synthesis philosophica, 30 (1), str. 33-46.

85. Jurić, H. (2017). The Footholds of an Integrative Bioethics in the Work of Van Rensselaer Potter. Facta Universitatis, 15 (2), 127-144.

86. Kaipainen, M., \& Hautamäki, A. (2011). Epistemic pluralism and multi-perspective knowledge organization : explorative conceptualization of topical content domains. Knowledge Organization, 38 (6), str. 503-514.

87. Kleineberg, M. (2014). Integrative levels of knowing. An organizing principle for the epistemological dimension. U: Wiesław, B. (ur.) Knowledge organization in the 21st century: between historical patterns and future prospects: Proceedings of the Thirteenth International ISKO Conference (Kraków, Poland, May 19-22, 2014). Advances in knowledge organization, no. 1. Würzburg : Ergon. Str. 80-87.

88. Kleineberg, M. (2016). Integral methodological pluralism : an organizing principle for method classification. Advances in Knowledge Organization, 15, str. 133-141.

89. Kos, M. (2014). Od Fritza Jahra do integrativne bioetike. Prikaz razvoja jedne ideje. Filozofska istraživanja, 34 (1/2), str. 229-240.

90. Kumar, S. \& Senthilkumar, R. (2019). Applicability of Lotka's Law in Astronomy \& Astrophysics Research of India. Library Philosophy and Practice (e-journal). 2129.

91. Kyle, B. (1958). Towards a classification for social science literature. American Documentation, 9 (3), str. 168-[184].

92. Leon Manifesto. (2021.). URL: http://www.iskoi.org/ilc/leon.php (25.5.2021).

93. Lesk, M. (1996). The seven ages of information retrieval. U: The IFLA Core Programme on Universal Dataflow and Telecommunications Occasional Paper No. 5. Morristown, NJ : Bellcore. Str. 1-15.

94. Long, A. (1984). UK MARC and US/MARC : a brief history and comparison. Journal of Documentation, 40 (1), str. 1-12.

95. López-Huertas, M. J. (2013). Reflexions on multidimensional knowledge : its influence on the foundation of knowledge organization. Knowledge Organization, 40 (6), str. 400-407.

96. López-Huertas, M. J. (2015). Domain analysis for interdisciplinary knowledge domains. Knowledge Organization, 42 (8), str. 570-580. 
97. Mai, J.-E. (1999). A postmodern theory of knowledge organization. U: Hlava, M. M. K. \& Woords, L. (ur.) ASIS '99 : Proceedings of the 62nd ASIS Annual Meeting, Washington, DC, October 31-November 4, 1999 : Knowledge, Creation, Organization and Use. Silver Spring, MD : American Society for Information Science. Str. 547556.

98. Mai, J.-E. (2008). Actors, domains and constraints in the design and construction of controlled vocabularies. Knowledge Organization, 35 (1), str. 16-29.

99. Miksa, F. L. (1994). Classification. U: Wiegand, W. A. \& Davis, D. G. (ur.) Encyclopedia of library history. New York [etc.] : Routledge. Str. 144-153.

100. Moher, D., Liberati A., Tetzlaffl, J. Altman, D. G. \& The PRISMA Group. (2009). Preferred reporting items for systematic reviews and meta-analyses : the PRISMA statement. British Medical Journal, 339. URL: http://www.prisma-statement.org/ (25.5.2021.).

101. Murphy, L. J. (1973). Lotka's Law in the Humanities? Journal of the American Society for Information Science, str. 461-462.

102. NCRBL. (1992). Tips On Searching BIOETHICSLINE With Grateful Med 6.0. URL: https://repository.library.georgetown.edu/bitstream/handle/10822/709397/Tips\%20fo r\%20Searching\%20Bioethicsline\%20with\%20Grateful\%20Med.pdf?sequence=1\&is Allowed=y

103. Nicolescu, B. (1994). The Charter of Transdisciplinarity. URL: https://inters.org/Freitas-Morin-Nicolescu-Transdisciplinarity

104. Nicolescu, B. (2014). Multidisciplinarity, Interdisciplinarity, Indisciplinarity, and Transdisciplinarity: Similarities and Differences. U: RCC Perspectives, No. 2, Minding the Gap: Working Across Disciplines in Environmental Studies. Str. 19-26.

105. Oštarić, R. (2014). Problem klasifikacije knjižnične građe iz medicinske etike, medicinske deontologije i bioetike unutar sheme univerzalne decimalne klasifikacije. Vjesnik bibliotekara Hrvatske, 57 (1/3), str. 177-200.

106. Pao, M. L. (1985). Lotka's Law : a Testing Procedure. Information Processing and Management, 21 (4), str. 305-320.

107. Philpapers.org. (2021). URL: https://philpapers.org/ (4.12.2021.).

108. Pickard, J. (2013). Research methods in information. London : Facet.

109. Rayward, B. (1997). International Federation for Information and Documentation. U: Wiegand, W. A. \& Davis, D. G. (ur.) Encyclopedia of library history. New York [etc.] : Routledge. 
110. Robinson, G. (1997). An odd point of view : some reflections on Table $1 \mathrm{i}$ in the UDC common auxiliaries. Extensions and Corrections to the UDC, 19, str. 29-31.

111. SIBI. (2021). Italian Thesaurus on Bioethics. URL: https://www.iss.it/sibi (4.12.2021.).

112. Smiraglia, R. P. (2015). Domain analysis for knowledge organization : Tools for ontology extraction. Amsterdam [etc.] : Elsevier ; Chandos.

113. Spitteri, L. (1995). The classification research group and the theory of integrative levels. Katharine Sharp Review, 1, str. 1-6.

114. Sugimoto, C. R., \& Weingart, S. (2015). The kaleidoscope of disciplinarity. Journal of Documentation, 71 (4), str. 775-794.

115. Suresh Kumar, P. K. (2017). Author productivity and the application of Lotka's Law in LIS publications. Annals of Library and Information Studies, 64, str. 234-241.

116. Sweeney, R. (1983). The development of the Dewey Decimal Classification. Journal of Documentation, 39 (3), str. 192-205.

117. Szostak, R. (2014). How universal is universality? Knowledge Organization, 41 (6), str. $468-470$.

118. Szostak, R., Gnoli, C., \& López-Huertas, M. (2016). Interdisciplinary knowledge organization. Cham: Springer International Publishing.

119. Špiranec, S. (2015). Subjective paradigm in subject indexing. Vjesnik bibliotekara Hrvatske, 57 (1/3), str. 1-14.

120. Tedd, L. A. (1987). Computer-based library systems : a review of the last twenty-one years. Journal of Documentation, 43 (2), str. 145-165.

121. Tennis, J. (2003). Two axes of domains for domain analysis. Knowledge Organization, 30 (3/4), str. 191-195.

122. Universal Decimal Classification Consortium (2021.) About UDC. UDC History. URL: http://www.udcc.org/index.php/site/page?view=about_history (25.5.2021).

123. Vickery, B. C. (1952). Notational symbols in classification. Journal of Documentation, 8 (1), str. 14-32.

124. Vickery, B. C. (1954). The changing structure of knowledge. Annals of Library and Information Studies (ALIS), 1, str. 137-147.

125. Vickery, B. C. (1962). Classification for documentation. Aslib Proceedings, 14 (8), str. 243-247.

126. Vickery, B. C. (1986). Knowledge representation : a brief review. Journal of Documentation, 42 (3), str. 145-159. 
127. Vickery, B. C. (1997). Issues in knowledge organization. U: Gilchrist, A. (ur.). From classification to „knowledge organization“. Dorking revisited or „Past is prelude“. A collection of reprints to commemorate the forty year span between Dorking Conference (First Study Conference on Classification Research 1957) and the Sixth International Study Conference on Classification Research (London, UK) 1997. FID 714. The Hague : International Federation for Information and Documentation. Str. $180-[?]$.

128. Zagorac, I. \& Jurić, H. (2008). Bioetika u Hrvatskoj. Filozofska istraživanja, 28 (3), str. 601-611. 


\section{Popis literature - istraživački materijal}

129. Aleksandrova-Yankulovska, S. (2014). Bulgaria. U: ten Have, H. \& Gordijn, B. (ur.) Handbook of Global Bioethics. Netherlands : Springer. Str. 905-924.

130. Andoh, C. (2016). African Communitarian Bioethics and the Question of Paternalism. British Journal of Education, Society \& Behavioural Science, 15 (4), str. 1-16.

131. Arëas, A. P. (2016). Introdução à Biotecnologia e à Bioética. U: Visao critica da biotecnologia. Santo André, SP : UFABC, Núcleo de Tecnologias Educacionais. Str. $11-22$.

132. Azariah, J. (2016). New Reachable Horizons in the Fritz Jahr's Bioethical Imperative. Jahr, 7 (14), str. 165-180.

133. Babel, K. (2012). Metafore zdravlja i bolesti u medicinskoj praksi. Filozofska istraživanja, 32 (1), str. 121-138.

134. Banović, B. \& Turanjanin, V. (2014). Euthanasia : Murder or Not : A Comparative Approach. Iranian Journal of Public Health, 43 (10), str. 1316-1323.

135. Baranzke, H. (2012). Was bedeutet „Ehrfurcht“ in Albert Schweitzers Verantwortungsethik? Eine Begriffsanalyse im Vergleich mit Schwantje, Kant, Goethe und Nietzsche. Synthesis philosophica, 27 (1). Str. 7-29.

136. Baranzke, H. (2016). Do animals have a moral right to life? U: Meijboom, F. L. B., \& Stassen, E. N. (ur.). The end of animal life: A start for ethical debate: Ethical and societal considerations on killing animals. Wageningen : Academic Publishers.

137. Barišić, P. (2009) Pluriperspektivizam - temeljni uvjet ili zatamnjenje istine? U: Valjan, V. (ur.) Integrativna bioetika i interkulturalnost. Sarajevo : Bioetičko društvo u BiH. Str. 25-38.

138. Barišić, P. (2010). Pluriperspektivismus - Grundbedingung oder Ausblendung der Wahrheit? U: Čović, A. (ur.) Integrative Bioethik und Pluriperspektivismus. Sankt Augustin : Academia. Str. 55-67.

139. Beever, J. \& Whitehouse, P. J. (2017). The Ecosystem of Bioethics : Building Bridges to Public Health. Jahr, 8 (2), str. 227-243.

140. Berberović, Lj. (2006). Bioetika - korijeni i preokupacije. Pregled - časopis za društvena pitanja, 3, str. 163-174.

141. Boesch, B. (2016). A MacIntyrean Critique of Theoretical Pluralism in Applied Ethics. The American Journal of Bioethics, 16 (9), str. 41-43. 
142. Borovečki, A. (2014). Croatia. U: ten Have, H. \& Gordijn, B. (ur.) Handbook of Global Bioethics. Netherlands : Springer. Str. 1049-1065.

143. Borš, V. (2016). The True as a Bacchantic Ecstasy : The Role and Importance of Pluriperspectivism in Hegel's Thought. Filozofska istraživanja, 36 (4), str. 775-785.

144. Bracanović, T. (2012). From Integrative Bioethics to Pseudoscience. Developing World Bioethics, 12 (3), str. 148-156.

145. Bracanovic, T. (2013). Against culturally sensitive bioethics. Medicine, Health Care and Philosophy, 16 (4), str. 647-652.

146. Brdarević, M. \& Pranjić Kozlek, Z. (2017). Prijateljstvo kao vrlina u praksi medicinske sestre u odnosu na Aristotelovu etiku. Journal of Applied Health Sciences, 3 (1), str. 89-98.

147. Brkljačić Žagrović, M., et al. (2011). Može li suvremeni sport bez svoje etike? potreba za sustavnom edukacijom. Jahr, 2 (1), str. 93-110.

148. Buckeridge, J. (2012). A Part, Not Apart From Nature: The IUBS Ethics Commission - An Overview of a Journey: From 2000-2012. Biology International, 52, str. 5-13.

149. Čatić, I. (2013). Obrazovanje za izazove budućnosti. Pedagogijska istraživanja, 10 (1), str. 7-23.

150. Čatić, I., Runjić-Sokele, M. \& Žagar, Z. (2013). Uvod u sustavnosnu analizu tlačnog lijevanja metalnih taljevina. Strojarstvo, 55 (3), str. 181-187.

151. Cerovac, I. \& Dunatov, M. (2018). Liberalni odgovori na problem uskraćivanja zdravstvene skrbi djeci i maloljetnicima iz religijskih razloga. Jahr, 9 (1), str. 43-60.

152. Chadwick, R. \& Wilson, D. (2018). The Emergence and Development of Bioethics in the UK. Medical Law Review, 26 (2), str. 183-201.

153. Chadwick, R. (2015). Getting ethics : voices in harmony in bioethics. U: Huxtable, R. \& Meulen, R. ter (ur.) The voices and rooms of European bioethics. London : Routledge. Str. 31-40.

154. Chrysanthou, A. \& Nottingham, E. (2018). Conferences as a Tool for Interdisciplinary (Postgraduate) Learning in Bioethics. Jahr, 9 (2), str. 234-246.

155. Cifrić, I. \& Marinović Jerolimov, D. (2007). Pobačaj kao bioetički izazov. Sociologija i prostor, 45 (3/4), str. 247-268.

156. Cifrić, I. (2005). Odgovornost za život u kontekstu bioetičkih pitanja. Socijalna ekologija, 14 (4), str. 295-326.

157. Cifrić, I. (2006). Bioetička ekumena. Potreba za orijentacijskim znanjem. Socijalna ekologija, 15 (4), str. 283-310. 
158. Cifrić, I. (2009). Život u Granicama Kulture. Arhe, 6 (12), str. 69-83.

159. Cifrić, I., \& Trako Poljak, T. (2012). Percepcija prava živoga svijeta i motivi čovjekova djelovanja. Socijalna ekologija, 21 (2), str. 123-154.

160. Cifrić, I., Nikodem, K. (2010). Attitude towards Life as a Bioethical Challenge. U: Čović, A. (ur.) Integrative Bioethik und Pluriperspektivismus. Sankt Augustin: Academia Verlag. Str. 208-222.

161. Cornejo Plaza, M. I. \& Rodríguez Yunta, E. (2016). From Kant's categorical imperative to Fritz Jahr's bioethical imperative: toward the globalization on ethics. U: Byk, C. \& Sass, H. M. (ur.) Fritz Jahr (1895-1953) From the origin of bioethics to integrative bioethics. Esika, París.

162. Čović, A. (2005). Bioethik unter den Bedingungen des Postkommunismus Fallbeispiel Kroatien. U: Čović, A. \& Hoffmann, T. (ur.) Bioethik und kulturelle Pluralität: Die südosteuropäische Perspektive. Sankt Augustin: Verlag Academia. Str. $148-172$.

163. Čović, A. (2006). Filozofija i pluralizam. Filozofska istraživanja, 26 (1), str. 7-12.

164. Čović, A. (2007). Der Aufbau eines Referenzzentrums für Bioethik in Südosteuropa: Ein Schritt zur Institutionalisierung des bioethischen Pluriperspektivismus. U: Čović, A. \& Hoffmann, T. (ur.) Integrative Bioethik. Sankt Augustin : Academia Verlag, str. 261274.

165. Čović, A. (2007). Integrativna bioetika i pluriperspektivizam. U: Valjan, V. (ur.) Integrativna bioetika i izazovi suvremene civilizacije. Sarajevo : Bioetičko društvo u BiH. Str. 65-75.

166. Čović, A. (2009). Biotička zajednica kao temelj odgovornosti za ne-ljudska živa bića. U: Čović, A., Gosić, N. \& Tomašević, L. (ur.) Od nove medicinska etike do integrativne bioetike. Zagreb : University of Zagreb. Str. 33-46.

167. Čović, A. (2009). Integrativna bioetika i problem istine. Arhe 12, str. 185-194.

168. Čović, A. (2011). Pojmovna razgraničenja: moral, etika, medicinska etika, bioetika, integrativna bioetika. U: Čović, A. \& Radonić, M. (ur.) Bioetika i dijete : Moralne dileme u pedijatriji. Zagreb: Pergamena : Hrvatsko društvo za preventivnu i socijalnu pedijatriju. Str. 11-24.

169. Čović, A. (2016). Otkriće i otkrivanje Fritza Jahra. Jahr, 7 (2), str. 193-194.

170. Čović, A. (2017). The Europeanization of Bioethics : Opportunities for Integrative Ethical Reflection on the Basis of Intra-Cultural Differences in Europe. Facta Universitatis, Series : Law and Politics, 15 (2), str. 111-114. 
171. Čović, A. (2019). Besmisao »primijenjene etike« : Od etičkog vakuuma do etičkog apsurda. Filozofska istraživanja, 39 (1), str. 247-264.

172. Čović, B. \& Marinčić, M. (2016). Social Responsibility for Healthy Society in the Context of Küng's Weltethos Project. Filozofska istraživanja, 36 (3), str. 473-491.

173. Ćurko, B. \& Kovačević, A. (2019). European projects related to ethical education in primary and secondary schools. Metodički Ogledi, 25 (2), str. 85-107.

174. Delić, Z., \& Šarić, H. (2013). Mogućnost kritike Bolonjskog sustava obrazovanja u Bosni i Hercegovini iz perspektive održivoga razvoja. Filozofska istraživanja, 33 (3), str. $441-457$.

175. DIALREL. (2010). Ethics Workshop 2: Judicial evaluation of the German dilemma: Freedom of Religion \& Animal Welfare as constitutional mandates U: The Ethics Workshops of the DIALREL Project DIALREL - Deliverable D 1.2. URL: https://doi.org/10.5771/9783845221120-210

176. DiEuliis, D. \& Giordano, J. (2016). Neurotechnological Convergence and "Big Data" : A Force-Multiplier Toward Advancing Neuroscience. U: Collmann, J. \& Matei, S. A. (ur.) Ethical Reasoning in Big Data. Cham : Springer International Publishing. Str. 7180 .

177. Donev, D. (2010). The Development of Bioethical Consciousness in Macedonia : The Absence of Legislative Dismissals and its Consequences. Jahr, 1 (1), str. 113-124.

178. Donev, D. (2012). Raskorak makedonskog obrazovnog sustava i svjetskih obrazovnih tendencija s obzirom na (bio)etičku edukaciju. Jahr, 3 (5), str. 29-36.

179. Donev, D. (2013). Etički aspekti suvremenog modela odnosa liječnik - bolesnik. Jahr, 4 (1), str. 503-512.

180. Donev, D. (2014). Korijeni bioetičke misli u Makedoniji. Znakovi vremena, Časopis za filozofiju, religiju, znanost $i$ društvenu praksu, 63, str. 53-65.

181. Donev, D. (2018). (Bio)ethical education of the young people in Macedonia. U: Sinaci, M. \& Lorenz Sorgner, S. (ur.) Ethics of Emerging Biotechnologies : From Educating the Young to Engineering Posthumans. [S.1.] : Trivent Publishing. Str. 134144.

182. Droste, S. (2008). Systematische Gewinnung von Informationen zu ethischen Aspekten in HTA-Berichten zu medizinischen Technologien bzw. Interventionen. Zeitschrift für Evidenz, Fortbildung und Qualität im Gesundheitswesen, 102 (5), 329341. 
183. Đurđić, V. \& Trajković, M. (2013). Ka pluriperspektivističkoj bioetici. Zbornik radova Pravnog fakulteta Novi Sad, 47 (2), str. 247-260.

184. Đurković, M. Pokušaj uvođenja surogat materinstva u Srbiju. Kulturna politika, 12 (27), str. 135-149.

185. Erhardt, J. \& Zagorac, I. (2019). Neuroenhancement and vulnerability in adolescence. Jahr, 10 (1), str. 149-170.

186. Eterović, I. \& Doričić, R. (2017). EuroBioAct : New paths of integrative bioethics. Nova Prisutnost, 15 (3), str. 392-392.

187. Eterović, I. (2011). Kant's Categorical Imperative and Jahr's Bioethical Imperative. Jahr, 2 (4), str. 457-474.

188. Eterović, I. (2011). Kantova teleologija kao podloga orijentiranju u ekologiji. Filozofska istraživanja, 31 (2), str. 299-309.

189. Eterović, I. (2014). Traženje uporišta za integrativno mišljenje u Kantovoj teoriji spoznaje. Filozofska istraživanja, 34 (4), str. 497-507.

190. Fellows, J. J. (2014). Downstream of the Experts : Trust-Building and the Case of MPAs. Social Epistemology, 28 (2), str. 187-207.

191. Festini, H. (2012a). Bioetika i filozofija biologije. Jahr, 3 (5), str. 279-284.

192. Festini, H. (2012b). Proteinska sinteza kao poluga evolucije. Jahr, 3 (2), str. 461-466.

193. Festini, H. (2014). Zašto trebamo znanje o obilježjima zakona u biologiji. Jahr, 5 (9), str. 83-95.

194. Filipović, N. (2014). Promjena znanstvene slike svijeta u kontekstu opće teorije o sistemima. Nova prisutnost, 12 (3), str. 401-411.

195. Fischer, et al. (2017). Da ética ambiental à bioética ambiental: antecedentes, trajetórias e perspectivas. História, Ciências, Saúde - Manguinhos, 24 (2), str. 391-409.

196. Frković, A. (2007). Bioetička edukacija u kliničkoj medicini. Metodički Ogledi, 14 (2), str. 33-48.

197. Fuchs, M. Ž. (2018). 'Science' and 'Culture' in University Settings. Areas of Overlap? Areas of Tension? Or, Areas of Mutual Complementarity? European Review, 26 (2), str. $319-329$.

198. Gajski, L. (2014). Lijekovi - previše, nepotrebno, štetno. Znakovi vremena, Časopis za filozofiju, religiju, znanost i društvenu praksu, 63, str. 207-222.

199. Garrett, J. R. (2015). Two Agendas for Bioethics : Critique and Integration : Two Agendas for Bioethics : Critique and Integration. Bioethics, 29 (6), str. 440-447. 
200. Giordano, J., Rossi, P. J. \& Benedikter, R. (2013). Addressing the Quantitative and Qualitative : A View to Complementarity-From the Synaptic to the Social. Open Journal of Philosophy, 3 (4), str. 1-5.

201. Gosić, N. (2009). Definitions of Bioethics in Bioethics Education in Croatia. Synthesis philosophica, 24 (2), str. 349-368.

202. Gosić, N. (2012). Bioetička edukacija u Hrvatskoj : Povijesni i aktualni pristup. Jahr, 3 (5), str. 99-110.

203. Gosić, N. (2012). Umjetna krv-profesionalni i etički izazovi. U: Valjan, V. (ur.) Integrativna bioetika pred izazovima biotehnologije. Sarajevo : Dobra knjiga d.o.o. Str. $229-262$.

204. Gosić, N. (2014). Jonas Edward Salk - pronalazač cjepiva protiv dječije paralize i utemeljitelj biofilozofije. Znakovi vremena, Časopis za filozofiju, religiju, znanost $i$ društvenu praksu, 63, str. 15-31.

205. Gosić, N. (2014). Pluriperspectivity and the Functionality of Contents of Bioethical Education in Croatia. U: Walter Schweidler, K. (ur.) Bioethik und Bildung. Sankt Augustin, Germany, Academia Verlag. Str. 223-234.

206. Grgec, G. (2006). Bioetika u BiH. Nova prisutnost, 6 (1), str. 181-187.

207. Grozdanić, V. (2017). Bioetički senzibilitet zakona o zaštiti osoba s duševnim smetnjama. Zbornik Pravnog fakulteta Sveučilišta u Rijeci, 38 (3), str. 929-946.

208. Gubenko, A. (2014). Bioethik in der Ukraine: Von Medizinischer zur Integrativen Bioethik. Jahr, 5 (1), str. 157-167.

209. Guć, J. (2018). Treba li se kritika bojati svojih rezultata? Filozofska istraživanja, 38 (2), str. 315-324.

210. Hasanović, Z. \& Jašić, O. (2012). Fakultet islamskih nauka s osvrtom na bioetičku edukaciju. Vrhbosnensia, 51 (1), str. 95-112.

211. Hodžić, Dž. (2008). Živa bića u islamskoj religijskoj bioetičkoj perspektivi. Socijalna ekologija, 17 (4), str. 361-378.

212. Hodžić, Dž. (2011). Whiteheadova filozofija prirode i bioetika. Filozofska istraživanja, 31 (2), str. 291-297.

213. Hoffmann, T. S. (2015). The Philosophical Concept of Life and Its Role in the Foundation of an Integrative Bioethics. Synthesis Philosophica, 59 (1), str. 5-15.

214. Hofmann, C. (2014). Autonomy and the concrete universal. Moral subjectivity and its function in Hegel's Philosophy of Right. Hegel Bulletin, 35 (2), str. 252-272. 
215. Holy, M. (2018). Globalizacija, integracija i multikulturalizam : interdisciplinarni pristup. Suvremene teme, 9 (1), str. 11-29.

216. Hršak, D. (2017). Uvod u holistički environmentalizam. Jahr, 8 (1), str. 83-96.

217. Hubenko, A. (2014). Integrative Pedagogical Bioethics. Future Human Image, 1 (4), str. 33-34.

218. Ilkilić, I., Ertin, H. \& Brömer, R. (2016). Fritz Jahr and global bioethics analyses and reflections from the perspective of Islamic tradition. Journal international de bioethique et d'ethique des sciences, 27 (4), str. 73-132.

219. Ivanković, V. \& Savić, L. (2016). Integrative Bioethics : a Conceptually Inconsistent Project. Bioethics, 30 (5), str. 325-335.

220. Janeš, L. (2017). Paradogma of the Psychic Entropy of Evil and the Palingenesis of All-Oneness. Synthesis Philosophica, 32 (1), str. 31-50.

221. Janeš, L. (2018). Budućnost filozofije psihe u Hrvatskoj. Filozofska istraživanja, 38 (2), str. 293-214.

222. Jašić, O., \& Hasanović, Z. (2013). Slijepi u islamu. Jahr, 4 (1), str. 385-404.

223. Jašić, O., \& Kaluđerović, Ž. (2015). Perception of quality of life among student population at the University of Tuzla. Kom : časopis za religijske nauke, 4 (1), str. 5777.

224. Jeličić, A. (2014). Franjevačka zauzetost za očuvanje dostojanstva i integriteta stvorenog. Filozofska istraživanja, 34 (4), str. 559-575.

225. Jeličić, A. (2014). Teološko poimanje dostojanstva života i patnje - katolički doprinos bioetici. Znakovi vremena, Časopis za filozofiju, religiju, znanost i društvenu praksu, 7 (63), str. 81-93.

226. Jeličić, A. (2015). Intelektualna i duhovna baština Pierrea Teilharda de Chardina iz perspektive suvremenih bioetičkih problema. Filozofska istraživanja, 35 (2), str. 289300 .

227. Jelkić, V. \& Reškovac, L. (2011). Nietzscheovo poimanje života. Cris, 13 (1), str. $145-155$.

228. Jelkić, V. (2011). Kakvo znanje trebamo? Filozofska istraživanja, 31 (2), str. 255-261.

229. Ježić, M. (2014). Kulturne perspektive i znanstvena metodologija. Filozofska istraživanja, 34 (4), str. 471-485.

230. Jošt, M. \& Samobor, V. (2008). Breeding Wheat for Organic Cropping System. Agronomski glasnik, 70 (6), str. 543-561. 
231. Jošt,

M.

(2014).

Bioethics

Of

Agriculture. URL:

https://www.researchgate.net/publication/266200009_BIOETHICS_OF_AGRICULTU RE (4.12.2021.).

232. Jurić, H. (2008). Ugrožavanje prirode i kulture kao izazov za bioetiku i multikulturalizam. Filološke studije, 6 (1), 1-9.

233. Jurić, H. (2009). Tierseele und Tierrechte : Fragen und Antworten zur Philosophie Hans Jonas'. U: Schweidler, W. (ur.) Wert und Würde der nichtmenschlichen Kreatur : Beiträge des 3. Südosteuropäischen Bioethik-Forums, Mali Lošinj. Sankt Augustin : Academia Verlag. Str. 111-123.

234. Jurić, H. (2010). Feminism in the Light of the Bioethical Pluri-Perspectivism. U: Čović, A. (ur.) Integrative Bioethik und Pluriperspektivismus. Sankt Augustin: Academia Verlag, 2010. Str. 237-243.

235. Jurić, H. (2011). Hans Jonas' integrative philosophy of life as a foothold for integrative bioethics. Jahr, 2 (2), str. 511-520.

236. Jurić, H. (2012). Multi-disciplinarity, pluri-perspectivity and integrativity in the science and the education. The holistic approach to environment, 2 (2), str. 85-90.

237. Jurić, H. (2015). From the Notion of Life to an Ethics of Life. Synthesis philosophica, 30 (1), str. 33-46.

238. Jurić, H. (2016). Fritz Jahr, European Bioethics, and Integrative Bioethics. Jahr, 7 (2), str. 192-192.

239. Jurić, H. (2017). Der Beitrag von Albert Schweitzer, Fritz Jahr und Hans Jonas zur Bioethik und ihre Rezeption in Südosteuropa. U: Hoffmann, T. (ur.) Integrative Bioethik: Grundlagen und Konkretionen. Hagen : Fer Universität Hagen. Str. 137-154.

240. Jurić, H. (2017). The Footholds of an Integrative Bioethics in the Work of Van Rensselaer Potter. Facta Universitatis, 15 (2), 127-144.

241. Kalokairinou, E. M. (2016). Fritz Jahr's Bioethical Imperative: Its Origin, Point, and Influence. Jahr, 7, (2), str. 149-156.

242. Kaluđerović, Ž. (2009). Bioetički pristupi životinjama. Socijalna ekologija, 18 (3/4), str. 311-322.

243. Kaluđerović, Ž. (2011). Aristotelovo razmatranje logosa, »volje« i odgovornosti kod životinja. Filozofska istraživanja, 31 (2), str. 311-321.

244. Kaluđerović, Ž. (2015). "Upward Levelling” of Plants - Early Greek Perspective. Jahr, 6 (2), str. 201-214. 
245. Kaluđerović, Ž. (2015). Ancient Greek roots of modern advocating for animal protection and welfare. Studia Universitatis Babes-Bolyai - Bioethica, 60 (2), str. 2943.

246. Kaluđerović, Ž., \& Jašić, O. (2015). Pitagorejska i arapska recepcija ne-ljudskih živih bića. Nova prisutnost, 13 (1), str. 25-33.

247. Kantar, S., \& Svržnjak, K. (2007). Prilozi za bibliografiju o bioetici u hrvatskoj (1990.-2007.). Socijalna ekologija, 16 (2/3), str. 231-248.

248. Katinić, M. (2012). Filozofija za djecu i mlade i integrativna bioetika. Filozofska istraživanja, 32 (3/4), str. 578-603.

249. Katinić, M. (2013). Sveto i profano u kontekstu bioetičke problematike: poremećaj ravnoteže ekosustava djelovanjem ekotoksikologije moći. Socijalna ekologija, 22 (1), str. 47-64.

250. Kelam, I. (2016). Odgovorno upravljanje poljoprivrednim zemljištem. Jahr, 7 (2), str. $203-215$.

251. Kelam, I. (2017). GMO 2.0: Novi naziv - stari problem. Socijalna ekologija, 26 (1/2), $45-59$.

252. Kishore, R. R. (2016). Bioethics, virtues and human dignity: Western notion and the Indian perception. Journal international de bioethique et d'ethique des sciences, 27 (4), str. 89-133.

253. Knezović, K. (2010). Das Retinitätsprinzip - ein pluriperspektivischer Zugang der integrativen Bioethik. U: Čović, A. (ur.) Integrative Bioethik und Pluriperspektivismus. Sankt Augustin : Academia Verlag. Str. 174-179.

254. Komušanac, M. \& Šterc, S. (2010). Historical Geography - the Basic Identity of the Geography Discipline. Hrvatski geografski glasnik, 72 (2), str. 140-142.

255. Kos, M. (2014). Lud, zbunjen, političan i subjekt. Jahr: Europski časopis za bioetiku, 5 (9), str. 211-221.

256. Kos, M. (2014). Od Fritza Jahra do integrativne bioetike. Prikaz razvoja jedne ideje. Filozofska istraživanja, 34 (1/2), str. 229-240.

257. Krznar, T. (2012). Beyond destruction : possibility of a new paradigm of knowledge. The holistic approach to environment, 2 (1), str. 29-40.

258. Krznar, T. (2015). While we are standing away. Do we need to consider hunting as a bioethical issue? Jahr, 6 (2), str. 191-200.

259. Krznar, T. (2017). Remarks on Understanding Phenomenon of Life in the Philosophy of José Ortega y Gasset. Synthesis philosophica, 32(2), str. 421-432. 
260. Krznar, T., et al. (2018). Acquaintance with bioethical concepts and attitudes towards some bioethical issues: example of teacher education students. Studia lexicographica, 12 (22), str. 7-25.

261. Kukoč, M. (2007). Filozofija i bioetika u Hrvatskoj. U: Valjan, V. (ur.) Integrativna bioetika i izazovi suvremene civilizacije. Sarajevo : Bioetičko društvo u BiH. Str. 109118.

262. Kukoč, M. (2012). Development of integrative bioethics in the Mediterranean area of South-East Europe. Medicine, Health Care and Philosophy, 15 (4), 453-460.

263. Lima, N. S. \& Cicovacki, P. (2014). Bio-Ethics: Past, present, and future. Jahr, 5 (2), $263-275$.

264. Marinčić, M. \& Čović, B. (2012). Mogući doprinosi integrativne bioetike u premošćivanju jaza u odnosu vjera - znanost. Obnovljeni život, 67 (1), str. 107-122.

265. Marinčić, M. \& Leš, J. B. (2018). Pčele - vrlo važne za prirodu i ljude. Journal of Applied Health Sciences, 4 (1), 91-99.

266. Marinčić, M. \& Svetoivanec-Marinčić, S. (2018). Philosophy and corporate social responsibility (ethical, ecological and cultural approach). Obrazovanje za poduzetništvo - E4E, 8 (2), str. 139-152.

267. Marinčić, M. (2011). O poduzetniku (bio)etičaru u okviru Ulrichova koncepta integrativne gospodarske etike. Učenje za poduzetništvo, 1 (1), str. 177-195.

268. Marinčić, M. (2013). Poticaji socijalnog nauka Crkve u razvoju demokracije, S posebnim osvrtom na vjernika laika i hrvatsko društvo. Crkva u svijetu, 48 (1), 50-72.

269. Marinkovic, D. \& Magic, Z. (2012). Serbian bioethics from an international perspective: Genetics and bioethics. Filozofija i društvo, 23 (4), 80-86.

270. Marjanović, M. (2012). Sociološki pojam morala. Zbornik radova Pravnog fakulteta Novi Sad, 46 (4), pp. 55-67.

271. Marjanović, M. (2014). Bioethics and Religion: From the Beginning of Bioethics to the Global Ethic. Zbornik radova Pravnog fakulteta Novi Sad, 48 (4), str. 57-68.

272. Marković, M., Radenović, S. \& Bokan, B. (2016). Health Education and Physical Education-Meeting Points. Filozofska istraživanja, 36 (3), 531-543.

273. Maros, Z. (2015). Umjetna oplodnja s osvrtom na federalni nacrt zakona o liječenju neplodnosti : osnovni, nezaobilazni podaci. Vrhbosnensia, 19 (1), str. 45-63.

274. Matulić, T. (2007). Istraživanje korijena mediteranske bioetike. Etika vrline i sreće kao conditio sine qua non. Filozofska istraživanja, 27 (3), str. 529-550. 
275. Mester, B. (2014). Az ember és állat közötti fal döntögetése. U: Falak és választóvonalak a történelemben. Nyíregyházi Főiskola. Str. 299-310.

276. Mladina, N. (2009). Portret liječnika u ogledalu etike skrbi. U: Valjan, V. (ur.) Integrativna bioetika i interkulturalnost. Sarajevo: Bioetičko društvo u BiH.

277. Mladina, N. (2012). Bioetika i liječnik u partnerstvu s bolesnikom. Jahr, 3 (1), 181190.

278. Mladina, N. (2013). Bioetika i medicina. Gradovrh, 10 (10), str. 197-203.

279. Mladina, N. (2014). Etički aspekti partnerstva sa pacijentima. Rauche, str. 8-11.

280. Mladina, N. (2014). Kvaliteta dječijeg razvoja u kontekstu bioetike. Znakovi vremena, 16 (63), str. 223-231.

281. Moore, C. E., Warren, R. \& Maclin, S. D. (2012). Head and Neck Cancer Disparity in Underserved Communities: Probable Causes and the Ethics Involved. Journal of Health Care for the Poor and Underserved, 23 (4a), 88-103.

282. Muzur, A. \& Rinčić, I. (2012). Fritz Jahr: on how he had discovered bioethics and how bioethicists have discovered him. U: Muzur, A., Sass, H.-M. (ur.) Fritz Jahr and the Foundations of Global Bioethics: The Future of Integrative Bioethics. Münster: Lit. Str. 169-177.

283. Muzur, A. \& Rinčić, I. (2015). Two kinds of globality : a comparison of Fritz Jahr and Van Rensselaer Potter's bioethics. Global bioethics enquiry, 26, 23-27.

284. Muzur, A. \& Rinčić, I. (2016). Ignaz Bregenzer (1844-1906): a brief homage to the most important source of Fritz Jahr's ideas on animal ethics. Journal international de bioethique et d'ethique des sciences, 27 (4), str. 119-135.

285. Muzur, A. \& Rinčić, I. (2017). Science as religion: when science becomes (too) irrational. Psychiatria Danubina, 29 (S1), 79-81.

286. Muzur, A. (2014). The nature of bioethics revisited: A comment on Tomislav Bracanović. Developing World Bioethics, 14 (2), 109-110.

287. Muzur, A. (2016). Svijest na razmeđi biomedicinskog i društveno-humanističkog promišljanja. Nova prisutnost, 14 (3), 453-457.

288. Muzur, A. (2017). Europska bioetika: Nova povijest za novu budućnost. Socijalna ekologija, 26 (1/2), 61-70.

289. Muzur, A. (2018). Interdisciplinarity as a State of Mind: How Can Individuals and Societies Reach It? European Review, 26 (S2), str. 76-84. 
290. Muzur, A., \& Rinčić, I. (2011). Fritz Jahr (1895-1953) - the Man Who Invented Bioethics. A Preliminary Biography and Bibliography. Synthesis philosophica, 26 (1), str. $133-139$.

291. Muzur, A., \& Rinčić, I. (2011). Fritz Jahr (1895-1953): a life story of the "inventor" of bioethics and a tentative reconstruction of the chronology of the discovery of his work. Jahr, 2 (2), str. 385-394.

292. Muzur, A., \& Rinčić, I. (2015). Practical aspects of bioethics: some European and American views. Jahr, 6 (2), str. 223-226.

293. Muzur, A., Rinčić, I. \& Sodeke, S. (2016). The Real Wisconsin Idea: The Seven Pillars of Van Rensselaer Potter's Bioethics. Journal of agricultural \& environmental ethics, 29 (4), 587-596.

294. Novalić, F. (2007). Razvoj u uvjetima rasipanja i siromaštva - Razvoj nerazvijenosti. Nova prisutnost, 5 (3), str. 325-359.

295. Novalić, F. (2012). Smisao istine. Filozofska istraživanja, 32 (3/4), str. 453-469.

296. Ortmann, L. W., Barrett, D. H., Saenz, C., Bernheim, R. G., Dawson, A., Valentine, J. A. \& Reis, A. (2016). Public Health Ethics: Global Cases, Practice, and Context. U: Barrett, D. H. et al (ur.) Public Health Ethics: Cases Spanning the Globe. Springer International Publishing. Str. 3-35.

297. Ošlaj, B. (2014). Svjetski etos i njegova filozofska relevantnost. Filozofska istraživanja, 34(4), str. 487-496.

298. Oštarić, R. (2014). Problem klasifikacije knjižnične građe iz medicinske etike, medicinske deontologije i bioetike unutar sheme Univerzalne decimalne klasifikacije. Vjesnik bibliotekara Hrvatske, 57 (1/3), str. 177-200.

299. Pavić, Ž. (2010). Ideje umjesto ideologija. O projektu »Filozofska istraživanja«. Studia lexicographica, 4 (2), str. 76-123.

300. Pavić, Ž. (2014). Pluriperspektivizam - slučaj jedne natuknice u Filozofskome leksionu. Filozofska istraživanja, 34 (4), str. 577-600.

301. Perović, M. A. (2009). Etičke granice bioetike. Arhe, 6 (12), str. 7-24.

302. Perušić, L. (2018). Kozmobioetika : Uvodna rasprava o bioetičkim aspektima kozmičkog društva. Obnovljeni život, 73 (3), str. 311-328.

303. Perušić, L. (2018). Princip integrativnost. Arhe, 15 (1), str. 133-157.

304. Pessini, L. (2013). As origens da bioética: do credo bioético de Potter ao imperativo bioético de Fritz Jahr. Revista Bioética, 21 (1), str. 9-19. 
305. Pessini, L. (2013). At the origins of bioethics: From Potter's bioethical creed to Fritz Jahr's bioethical imperative. Revista Bioetica, 21 (1), str. 9-18.

306. Pessini, L. (2013). En la cuna de la Bioética: el encuentro de un credo con un imperativo y un principio. Revista Colombiana de Bioética, 8 (1), str. 8-31.

307. Pessini, L. (2013). No berço da bioética: o encontro de um credo, com um imperativo e um principio. Revista Colombiana de Bioética, 8 (1), str. 32-54.

308. Pessini, L. (2014). Bioética aos 40 anos: O encontro de um credo, com um imperativo e um princípio. Encontros Teológicos, 29 (1), str. 73-106.

309. Platovnjak, I. (2019). The Role of (Christian) Spirituality in the Economy in the Light of Laudato si'. Synthesis Philosophica, 34 (1), str. 73-86.

310. Pöltner, G. (2009). Pluriperspektivismus und Einheit der Vernunft. Überlegungen zu Einer Integrativen Bioethik. Arhe, 12, str. 43-50.

311. Pöltner, G. (2015). Menschennatur und Speziesismus. U: Rothhaar, M. \& Hähnel, M. (ur.) Normativität des Lebens - Normativität der Vernunft? De Gruyter. Str. 251-270.

312. Povrzanović, I., \& Mladinov, O. (2007). Osnivanje etičkog povjerenstva u pulskoj bolnici (Pravi bioetički počeci u Hrvatskoj). Glasnik pulske bolnice, 4 (S1), str. 130 135.

313. Pyrrho, M. (2014). Uma genealogia imunitária: a bioética e a busca da autoconservação humana. Revista bioethica, 22 (2), str. 225-233.

314. Račić, I., \& Jergović, B. (2012). Medijska slika bioetike - 9. svjetski bioetički kongres u Rijeci. Jahr, 3 (2), str. 433-459.

315. Radenović, S. \& Čačija, Ž. (2015). Sportsko tijelo - nekad i sad. Jahr, 6 (2), str. 341352.

316. Radenovic, S. \& Turza, K. (2007). Bioethical aspects of ethnic prejudice. Sociologija, 49 (4), str. 369-380.

317. Radenović, S. (2008). Medicinski otpad kao bioetički problem. Socijalna ekologija, 17 (3), str. 297-304.

318. Radenović, S. (2008). Vrednosti i život. Republika, 20, str. 432-433.

319. Radenović, S. (2010). Identitet(i) i (kritička) kultura sećanja - bioetički aspekti. Sociološka luča 4 (2), str. 133-143.

320. Radenović, S. (2012). Bioetika i nasilje. Jahr, 3 (1), str. 205-218.

321. Radenović, S. (2013). »Novi univerzitet« i orijentacijsko znanje - neka razmatranja. Metodički ogledi, 20 (1), str. 33-43. 
322. Radenović, S. (2014). Bioetika i rasizam - može li bioetika doprinijeti smanjenju rasizma? Znakovi vremena, 63, str. 187-203.

323. Radenović, S. (2021). Bioetika i medicinska sociologija - određenja, odnos i srbijanska iskustva. Znakovi vremena, 54, str. 139-149.

324. Radenović, S., et al. (2012). Institucionalizacija bioetike u Srbiji. Socijalna ekologija, 21 (3), str. 311-328.

325. Radenović, S., Jeremić, V. \& Turza, K. (2013). Bioetička edukacija i zdravstveni problemi romske populacije. Jahr, 4 (2), str. 773-778.

326. Reis, et al. (2016). Origem e perspectivas da Bioética no Brasil e em Portugal. Mirabilia Medicinae, 6 (1), str. 95-112.

327. Rendtorff, J. D. (2015). Update of European bioethics: Basic ethical principles in European bioethics and biolaw. Bioethics Update, 1 (2), str. 113-129.

328. RINČIĆ LERGA, I. (2009). Bioetička uporišta korporativne društvene odgovornosti. Društvena istraživanja, 18 (4/5), str. 807-823.

329. Rinčić, I. \& Muzur, A. (2011). European bioethics institutionalisation in theory and practice. Jahr, 2 (2), str. 415-429.

330. Rinčić, I. \& Muzur, A. (2011). Variety of Bioethics in Croatia: a Historical Sketch and a Critical Touch. Synthesis Philosophica, 52 (2), str. 403-428.

331. Rinčić, I. \& Muzur, A. (2011b). Fritz Jahr: The Invention of Bioethics and Beyond. Perspectives in Biology and Medicine, 54 (4), str. 550-556.

332. Rinčić, I. \& Muzur, A. (2012). Od bioetičara - učenika do bioetičara - učitelja: pijetizam i edukacija u životu i djelu Fritza Jahra. Jahr, 3 (1), str. 111-116.

333. Rinčić, I. \& Muzur, A. (2013). Deaf education in Croatia. Croatian Medical Journal, 54 (1), str. 89-90.

334. Rinčić, I. (2007). First International Summer School of Integrative Bioethics. Synthesis Philosophica, 44 (2), str. 523-536.

335. Rinčić, I. (2010). Teorija institucija Arnolda Gehlena: prilog istraživanju bioetičkih institucija. Filozofska istraživanja, 30 (1/2), str. 141-159.

336. Rinčić, I. (2012). Riječka deklaracija o budućnosti bioetike : okolnosti nastanka, sadržaj i odjeci. U: Donev, D. (ur.) Proceedings from first international interdisciplinary conference Bioethics - the sign of a new era: bioethics, media, law and medicine. Skopje : SS. Cyril and Methodius University in Skopje - Faculty of Law Justinianus Primus. Str. 99-103. 
337. Rinčić, I., \& Muzur, A. (2015). In search of (lost) connection: organic architecture and bioethics. The case of Frank Lloyd Wright (1867-1959). Jahr, 6 (2), str. 227-232.

338. Rinčić, I., Muzur, A. \& Bošković, S. (2014). The role of Faculty of Medicine in Rijeka in developing and promoting deaf culture: a few old experiences and a promising recent initiative with deaf education. Jahr, 5 (2), str. 309-322.

339. Rinčić, I., Sodeke, S. \& Muzur, A. (2016). From integrative bioethics to integrative bioethics: European and American perspectives. Journal international de bioéthique et d'éthique des sciences, 27 (4) str. 105-117.

340. Roa-Castellanos, R. A. (2011). Bioethical common factors amidst Krause masonry and Saint Francis of Assisi systems of thought appeal to respectful dialogue, nature and understanding : the Jahr's dialogue beyond the age of "enlightenment" and the metadisciplinary "dark" ages. Jahr, 2 (2), str. 533-564.

341. Roa-Catellanos, R. A. (2011). Declaración Internacional de Rijeka sobre el futuro de la Bioética. Bioethikos, 5 (3), str. 291-301.

342. Sadžakov, S. (2008). Labirinti etike. Od Kangrge do bioetike. Filozofska istraživanja, 28 (3), str. 589-600.

343. Sass, H. (2011). Can bioethics live without tradition and history? How Fritz Jahr translated the 5th Commandment into the present and future. A methodological and conceptual case study. Jahr, 2 (2), str. 395-405.

344. Sass, H. (2014). Integrate Bioethics in the New Epoch. Synthesis philosophica, 29 (2), str. 415-427.

345. Sass, H. (2015). Translating Asian Bioethics into developing global Biocultures Translational Challenges In Bioethics. Jahr, 6 (2), str. 177-190.

346. Sass, H. M. (2011). The Earth is a Living Being: We have to treat her as such! Eubios Journal of Asian and International Bioethics, 21 (3), str. 73-77.

347. Sass, H. M. (2012). The Biocosmological Imperative. Biocosmology, 2 (3), str. 246255.

348. Sass, H.-M. (2012). The "5-C Model” for Guiding Science and Technology: A Précis of Reasonable Moral Practice Amidst a Diversity of Worldviews. Synesis, 3, str. 52-59.

349. Sass, H.-M. (2014). Bioethik - Bioethics. Archiv für Begriffsgeschichte, 56, str. 221228.

350. Sass, H.-M. (2016). Cultural dimensions of bios and bioethics. Journal of Health Culture, 1 (1), str. 26-37. 
351. Sass, H.M. (2016). Towards a Bioethics of the Political Bios: Happiness, Health and Illness of Political and Social Bodies. Jahr, 7 (2), str. 259-278.

352. Savić, L. \& Ivanković, V. (2018). Against the integrative turn in bioethics: Burdens of understanding. Medicine, Health Care and Philosophy, 21 (2), str. 265-276.

353. Schaefer-Rolffs, J. (2012). Integrative Bioethics as a Chance. An Ideal Example for Ethical Discussions? Synthesis Philosophica, 53 (1), str. 107-122.

354. Selak, M. (2009). Bioetički osvrt na filozofiju Nikolaja A. Berdjajeva. Promišljanje degradacije duhovnosti i bîti tehnike u prijelomu epoha. Filozofska istraživanja, 29 (3), str. 603-614.

355. Selak, M. (2011). Philosophy of the world and philosophy of Karl Löwith as a precursor and incentive to the idea of integrative bioethics. Jahr, 2 (2), str. 525-532.

356. Selak, M. (2013). Pojam svijeta i metodologija nove znanosti. U: Jurić, H. \& Babel, K. (ur.) Integrativno mišljenje i nova paradigma znanja. Zagreb : Hrvatsko filozofsko društvo.

357. Selak, M. (2017). Informed consent between bioethical theory and medical practice : a call for active vulnerability. Facta Universitatis: Series: Law and Politics, 15 (2), str. $171-179$.

358. Škerbić, M. M. \& Radenović, S. (2018). Bioetika sporta : Prisutnost bioetičkih tema na području filozofije i etike sporta u Hrvatskoj i Srbiji. Jahr, 9 (2), str. 159-184.

359. Škerbić, M. M. (2014). Etika sporta kao novi nastavni predmet? Metodički ogledi, 21 (1), str. 47-66.

360. Škerbić, M. M. (2019). Bioethics of sport and its place in the philosophy of sport. Synthesis Philosophica, 34 (2), str. 379-374.

361. Smiljanić, D. (2011). Problem pogleda na svijet i integrativna bioetika. Filozofska istraživanja, 31 (2), str. 245-253.

362. Smiljanić, D. (2014). Revizija pojma bioetike kao zahtjev integrativnog mišljenja. Znakovi vremena, 63, str. 25-249.

363. Sodeke, S. (2016). Bioethics Skill Sets Can Work, But It Would Take Moral Courage to Apply Them and Get Desired Results. The American Journal of Bioethics, 16 (4), str. $19-21$.

364. Sodeke, S. O. \& Wilson, W. D. (2017a). Ethics Education and Ethics Committees for Neuroscience Research Is a Timely Proposition. AJOB Neuroscience, 8 (1), str. 20-23. 
365. Sodeke, S. O. \& Wilson, W. D. (2017b). Integrative Bioethics is a Bridge-Builder Worth Considering to Get Desired Results. The American Journal of Bioethics, 17 (9), str. 30-32.

366. Sodeke, S. O. \& Yates, C. C. (2016). Shared Governance Embedded in Population Ethics Can Enhance Health Equity Research at Both Micro and Macro Levels. The American Journal of Bioethics, 16 (10), str. 64-66.

367. Sodeke, S. O. (2012). Tuskegee University Experience Challenges Conventional Wisdom: Is Integrative Bioethics Practice the New Ethics for the Public's Health? Journal of Health Care for the Poor and Underserved, 23 (4a), str. 15-33.

368. Sorta-Bilajac Turina, I. (2017). Potterova „globalna“ bioetika kao odgovor na potrebu za „specijalnom“ etikom u javnom zdravstvu. Hrvatski časopis za javno zdravstvo, 13 (50), str. 6-13.

369. Sorta-Bilajac Turina, I., et al. (2014). Clinical Ethics in Croatia : An Overview of Education, Services and Research (An Appeal For Change). Acta clinica Croatica, 53 (2), str. 166-174.

370. Sorta-Bilajac Turina, I., et al. (2015). Current perspectives of Potter's global bioethics as a bridge between clinical (personalized) and public health ethics. Acta clinica Croatica, 54 (4), str. 509-515.

371. Sorta-Bilajac, I. \& Šegota, I. (2010). Is there a death with dignity in today's medicine? Journal international de bioethique, 21 (4), str. 149-167.

372. Spehnjak, M., Žilić Fišer, S. \& Labaš, D. (2018). Prikaz sustava vrijednosti hrvatskih nogometnih trenera. Crkva u svijetu, 53 (3), str. 539-566.

373. Stanković, B., et al. (2017). Mere zaštite zaposlenih u laboratorijama transfuziloških ustanova i odlaganje medicinskog otpada. Halo, 194, 23 (3), str. 149-162.

374. Steger, F. (2015). Fritz Jahr's (1895-1953) European concept of bioethics and its application potential. Jahr, 6 (2), str. 215-222.

375. Švogor Šipek, A. \& Krznar, T. (2016). Učestalost pojava tema odgoja i obrazovanja u programima znanstvene konferencije Lošinjski dani bioetike u razdoblju 2002.-2014. Nova prisutnost, 14 (1), str. 127-146.

376. Thomalla, K. (2008). Über die Abhängigkeit bioethischer Positionen von ihren jeweiligen Leitbegriffen und die Konsequenzen dieser Einsicht für die Debatte um die Biomedizin. Synthesis philosophica, 23 (2), str. 259-282.

377. Tićac, I. \& Marinović, S. (2017). Eko-etika između biocentrizma i antropocentrizma. Acta Iadertina, 9 (1), str. 47-59. 
378. Todorov, H. (2011). Avtoritetŭt v usloviyata na avtonomiya. U: Problemi na avtonomiyata $\mathrm{v}$ bioetikata.

379. Todorovic, Z. \& Protic, D. (2012). Bioethical issues in the development of biopharmaceuticals. Filozofija i društvo, 23 (4), str. 49-56.

380. Todorovic, Z. \& Protic, D. (2017). Patient autonomy and informed consent in critically ill. Hospital Pharmacology - International Multidisciplinary Journal, 4 (1), str. 463-468.

381. Todorovska, M. (2010). Interpretation and implementation of UNESCO's Universal Declaration on Bioethics and Human Rights. Jahr, 1 (1), str. 51-61.

382. Tomašević, L. (2011). Ontološko i funkcionalističko shvaćanje osobe : bioetička rasprava. Crkva u svijetu, 46 (2), str. 143-170.

383. Tomašević, L. (2013). Razvoj bioetike u Hrvatskoj. Crkva u svijetu, 48 (4), str. 488503.

384. Tomašević, L. (2013a). Bioethics in Catholic Theology and Scientific Bioethics. International Journal of BioMedicine, 54 (1), str. 86-88.

385. Tomašević, L. (2013b). Development and perspectives of theological bioethics. Croatian Medical Journal, 54 (1), str. 86-88.

386. Tomašević, L. (2014). Bioetika iz rusko-pravoslavne perspektive. Služba Božja, 54 (1), str. 35-51.

387. Tomašević, L. (2014). Die moralische Krise und die Entstehung der globalen Bioethik. U: Schweidler, W. \& Zeidler, K. W. (ur.) Bioethik und Bildung. Sankt Augustin : Academia Verlag. Str. 111-122.

388. Tomašević, L. (2015). Etike „trećeg lica“ i moralne vrednote. Služba Božja, 55 (2), str. $155-178$.

389. Trajković, M. \& Josić, N. (2011). Eutanazija u perspektivi kršćanske vjere i pravne znanosti. Filozofska istraživanja, 31 (2), str. 365-374.

390. Turković, K. (2010). Eutanazija i potpomognuto samoubojstvo - etičke dileme kriminalne politike. Hrvatski ljetopis za kazneno pravo i praksu, 17 (1), str. 223-246.

391. Turza, K. \& Radenović, S. (2012). Bioetička edukacija na Medicinskom fakultetu Sveučilišta u Beogradu. Jahr, 3 (1), str. 93-98.

392. Turza, K. (2012). Bioetika i kultura. Može li bioetika pridonijeti stvaranju interkulturalnosti? Jahr, 3 (1), str. 255-266.

393. Valjan, V. (2014). Pojam, značenje i nastanak bioetike sa posebnim osvrtom na Bosnu i Hercegovinu. Znakovi vremena, 17 (63), str. 47-52. 
394. Vasiljev Marchesi, V. \& Racz, A. (2018). Ekonomski, okolišni i etički utjecaj rasipanja hrane u uslužnim djelatnostimai drugim globalnim industrijama. Jahr, 9 (1), str. $25-42$.

395. Veatch, R. M. (2015). The Conflict between Advance Directives and Organ Donation : A New Problem in End-of-Life Planning. Jahr, 6 (2), str. 267-275.

396. Vrček, V. (2016). Status of Transgenic Crops in the Encyclical Laudato si'. Jahr, 7 (2), str. 217-223.

397. Vuletić, S., Jeličić, A. \& Karačić, S. (2014). Bioetičke konotacije interneta. Diacovensia, 22 (4), str. 525-558.

398. Vulić, N. (2012). Bioetičko obrazovanje u srednjoj školi. Jahr, 3 (5), str. 23-28.

399. Wilson, W. D., et al. (2013). The Fate of Local Food Systems in the Global Industrialization Market : Food and Social Justice in the Rural South. Professional Agricultural Workers Journal, 1 (1), n. 5, str. 1-8.

400. Zagorac, I. \& Jurić, H. (2008). Bioetika u Hrvatskoj. Filozofska istraživanja, 28 (3), str. 601-611.

401. Zagorac, I. (2010). Rehabilitacija senzibiliteta. Filozofijska konstrukcija senzibilnog čovjeka. Filozofska istraživanja, 30 (1/2), str. 123-140.

402. Zagorac, I. (2011). Fritz Jahr's Bioethical Imperative. Synthesis Philosophica, 51 (1), str. 141-150.

403. Zagorac, I. (2012). Kritičko mišljenje i bioetika. Jahr, 3 (1), str. 69-80.

404. Zagorac, I. (2017). Bioethical worldview. U: Byk, C. \& Sass, H. M. (ur.) Fritz Jahr (1895-1953) : From the Origin of Bioethics. Paris : MA Editions. Str. 131-143.

405. Zorzetto, S. (2014). La filosofía analítica de Uberto Scarpelli. Del análisis del lenguaje valorativo a los principios de la bioética. Derecho PUCP, 73, str. 535-582.

406. Анна Губенко. (2016). Модели интегративной биоэтики в разных странах. Філософія освіти, 19 (2). URL: https://cyberleninka.ru/article/n/modeli-integrativnoybioetiki-v-raznyh-stranah (4.12.2021). 


\section{POPIS ORIGINALNIH GRAFIČKIH I TABLIČNIH PRIKAZA}

Tabela 3. Pregled mogućnosti oblikovanja upita i obuhvaćenih godišta s obzirom na bazu podataka. 90

Tabela 4. Broj rezultata za pojedinačne upite s obzirom na bazu podataka i jezik (kolovoz 2018.)..... 94

Tabela 5. Raspodjela izvora u istraživačkom materijalu prema vrsti .................................................. 96

Tabela 6. Kriteriji isključivanja izvora u redoslijedu provedenih postupaka ...................................... 96

Slika 7. Vremenska distribucija produkcije članaka u području integrativne bioetike ....................... 102

Tabela 7. Zastupljene vrste izvora $u$ analiziranom setu .................................................................. 103

Tabela 8. Analiza izvora prema mjestu pojavljivanja istraživanog termina....................................... 103

Tabela 9. Najproduktivniji autori u području integrativne bioetike $(\mathrm{N}$ autorstava > 5) ...................... 104

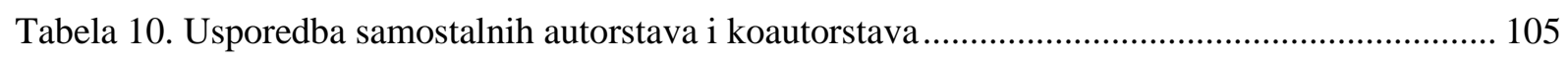

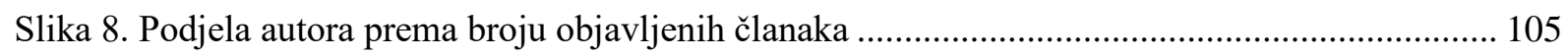

Slika 9. Primjenjivost Loktinog zakona na produktivnost autora u području integrativne bioetike ... 106

Tabela 11. Afilijacije autora analiziranih priloga ( $\mathrm{N}$ afilijacija > 4) ............................................... 108

Tabela 12. Afilijacije s domaćim i inozemnim institucijama............................................................ 109

Tabela 13. Obrasci znanstvene produktivnosti prema zemlji publiciranja radova ............................. 110

Tabela 14. Obrasci znanstvene produktivnosti prema kontinentu................................................... 111

Slika 10. Geografska distribucija znanstvene produkcije autora u području integrativne bioetike (Svijet)

Slika 11. Geografska distribucija znanstvene produkcije autora u području integrativne bioetike (Europa)

Tabela 15. Matične publikacije radova (časopisi)

Slika 12. Primjenjivost Bradfordovog zakona na produktivnost autora u području integrativne bioetike

Tabela 16. Prevalencija jezika obuhvaćenih radova

Tabela 17. Kategorizacija radova

Tabela 18. Distribucija dokumenata prema glavnim klasama fenomena Klasifikacije integrativnih razina 
PRILOZI

\section{PRILOG 1. Klasifikacijska shema istraživačke bioetičke knjižnice Kennedy instituta za etiku Sveučilišta u Georgetown-u}

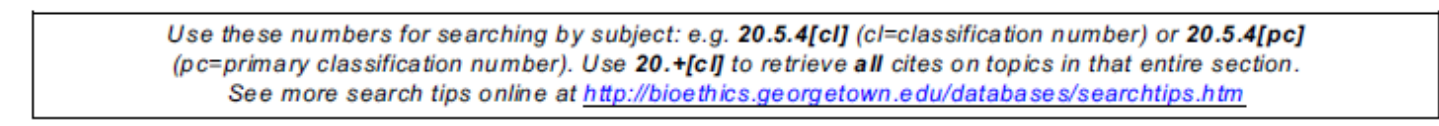

\section{BIOETHICS RESEARCH LIBRARY CLASSIFICATION SCHEME}

\begin{tabular}{|c|c|c|c|}
\hline \multicolumn{4}{|c|}{1 Ethics } \\
\hline & 1.1 & \multicolumn{2}{|c|}{ Philosophical Ethics } \\
\hline & 1.2 & \multicolumn{2}{|c|}{ Religious Ethics } \\
\hline & 1.3 & \multicolumn{2}{|c|}{ Applied and Professional Ethics } \\
\hline & & 1.3 .1 & Gen eral \\
\hline & & 1.3 .2 & Business \\
\hline & & 1.3 .3 & Education \\
\hline & & 1.3 .4 & Eng inearing \\
\hline & & 1.3 .5 & GovernmentC riminal Justice \\
\hline & & 1.3 .6 & International Affairs \\
\hline & & 1.3 .7 & Journalism/Mass Media \\
\hline & & 1.3 .8 & Law \\
\hline & & 1.3 .9 & Scientife Research \\
\hline & & 1.3 .10 & Social Work \\
\hline & & 1.3.11 & Agriculture \\
\hline & & 1.3 .12 & Information Technology \\
\hline & & 1.3.13 & Social Sciences \\
\hline \multicolumn{4}{|c|}{2 Bioethics } \\
\hline & 2.1 & \multicolumn{2}{|c|}{ General } \\
\hline & 2.2 & \multicolumn{2}{|c|}{ History of Health Ethics/Bioethics } \\
\hline & 2.3 & \multirow{2}{*}{\multicolumn{2}{|c|}{$\begin{array}{l}\text { Education/Programs } \\
\text { Commissions/Councils }\end{array}$}} \\
\hline & 2.4 & & \\
\hline \multicolumn{4}{|c|}{3 Philosophy of Biology } \\
\hline & 3.1 & \multicolumn{2}{|c|}{ General } \\
\hline & 3.2 & \multicolumn{2}{|c|}{ Evolution and Creation } \\
\hline \multirow{6}{*}{\multicolumn{2}{|c|}{$\begin{array}{l}4 \mathrm{Ph} \\
4 .\end{array}$}} & osophic & les of Medicine and Health \\
\hline & & \multicolumn{2}{|c|}{ Theory and Practice of the Health } \\
\hline & & & Professions \\
\hline & & 4.1.2 & Medicine \\
\hline & & 4.1.3 & Nursing \\
\hline & & 4.1.4 & Dentistry \\
\hline & 4.2 & Concer & pt of Health \\
\hline & 4.3 & Concer & pt of Mental Health \\
\hline & 4.4 & Quality & Nalue of Life/Personhood \\
\hline & 4.5 & Enhan & cement \\
\hline 5 & Scier & nce/Te & chnology and Society \\
\hline & 5.1 & Gener: & \\
\hline & 5.2 & Techno & ology/Risk Assessment \\
\hline & 5.3 & Social & Control of Science/Technology \\
\hline & 5.4 & Nanote & echnology \\
\hline 6 & $\begin{array}{l}\text { Code } \\
\text { Profe }\end{array}$ & $\begin{array}{l}\text { es of/P } \\
\text { ession: }\end{array}$ & $\begin{array}{l}\text { osition Statements on } \\
\text { al Ethics }\end{array}$ \\
\hline 7 & Soci & ology c & of Health Care \\
\hline & 7.1 & Gener: & \\
\hline & 7.2 & Educat & ition for Health Care Professionals \\
\hline & 7.3 & Profes: & sional-Professional Relationship \\
\hline & 7.4 & Profes: & sional Misconduct \\
\hline 8 & Patie & ent Rel: & lationships \\
\hline & 8.1 & Gener: & \\
\hline & 8.2 & Truth D & Disclosure \\
\hline & 8.3 & Informe & ed Consent \\
\hline & & 8.3 .1 & Gen eral \\
\hline & & 8.3 .2 & Parental Consent/M inors \\
\hline & & 8.3 .3 & Third Party Conse nt/heompe sents \\
\hline & & & Right to Refuse Trea tm ent \\
\hline & & 8.3 .5 & Bills, Laws and Cases \\
\hline & 8.4 & Confide & lentiality \\
\hline & 8.5 & Malpra & actice \\
\hline 9 & Healt & th Care & \\
\hline & 9.1 & Gen & \\
\hline & 9.2 & Righ & ht to Health Care \\
\hline & 9.3 & Heal & Itth Care Economics \\
\hline & & 9.3.1 & 1 General \\
\hline & & 9.3 .2 & 2 Managed Care \\
\hline & 9.4 & Alloc & cation of Health Care Resources \\
\hline & 9.5 & Hea & alth Care for Specific \\
\hline
\end{tabular}

9.5.1 General

$\begin{array}{rrr}9.5 .3 & \text { Developm } \\ 9.5 .4 & \text { Minorifes }\end{array}$

9.5 .4 Minorifes

9.5.6 HN Infection and A IDS

9.5.7 Newborns and Minors

$\begin{array}{ll}\text { 9.5.8 } & \text { Embryos and Fetuses } \\ 9.5 .9 & \text { Substance Abusers/Users }\end{array}$

Substance Abusere/Us
Controlled Sub stances

9.5.10 Indigents

9.6 Ethics Committees/Consultation

9.7 Drugs and Drug Industry

10 Sexuality/Gender

11 Contraception

11.1 General

11.2 Availability of Contraceptives to

Minors

11.3 Sterilization

11.4 Failure of Contraception/Wrongful Birth

12 Abortion

12.1 Genera

12.2 Position Statements

12.3 Moral and Religious Aspects

12.4 Legal Aspects

12.4 .1 General

12.4.2 In terests of Wom an/F etus IF ather

12.4.3 in terests of Health P ersonnell

Institutions

12.5 Social Aspects

12.5.1 General

12.5.2 Demographic Surveys/Ats tudes

12.5.3 Abortion Counselling

13 Population

13.1 General

13.2 Population Grown

13.3 Population Policy

14 Reproduction/Reproductive Technologies

14.1 General

14.2 Artificial Insemination and Surrogacy

14.3 Sex Predetermination/Selection

14.4 In Vitro Fertilization and Embryo Transfer

14.5 Cloning

14.6 Cryobanking of Sperm, Ova, or

Embryos

15 Genetics, Molecular Biology and

Microbiology

15.1 General

15.3 Genetic Screening/Testing

15.4 Gene Therapy/Transfer

15.5 Eugenics

15.6 Behavioral Genetics

15.7 Biohazards of Genetic Research

15.8 Genetic Patents

15.9 Sociobiology

15.10 Genome Mapping

15.11 Genetics and Human Ancestry

16 Environmental Quality

16.1 General

16.2 Nuclear Power/Radiation

16.3 Occupational Health

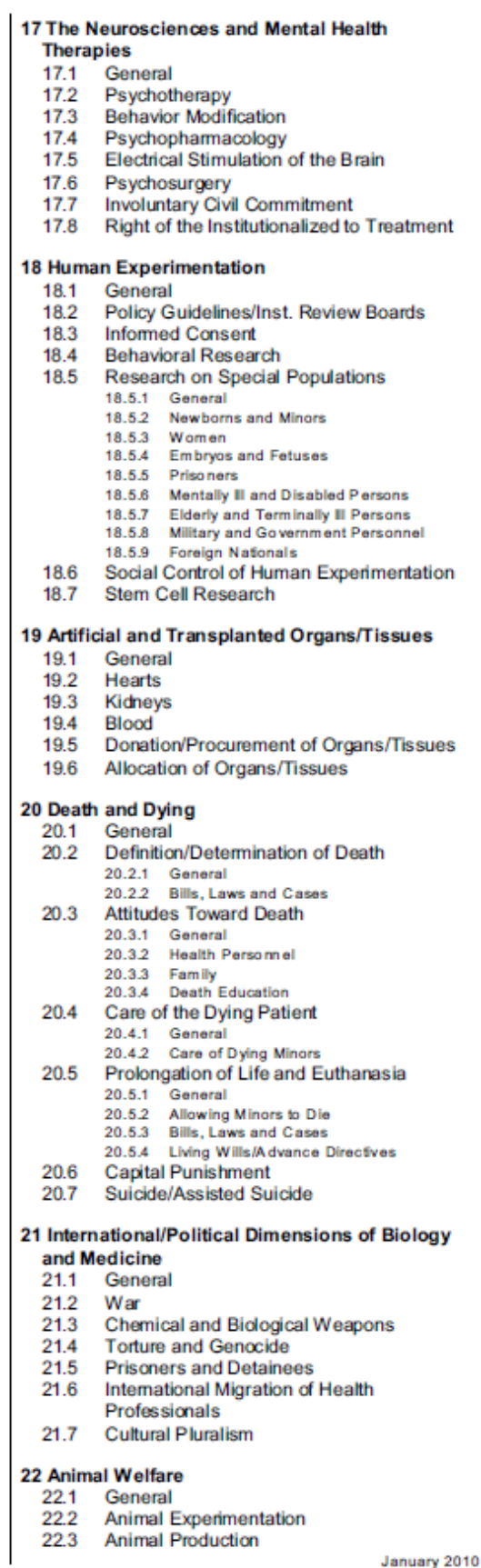




\section{PRILOG 2. Matične publikacije dokumenata iz analiziranog seta literature}

Naslov knjige

Integrative Bioethik und Pluriperspektivismus

$\mathbf{N}$

Handbook of Global Bioethics

Integrativna bioetika i interkulturalnost

Fritz Jahr (1895-1953): From the Origin of Bioethics

Integrativna bioetika i izazovi suvremene civilizacije

Integrativna bioetika pred izazovima biotehnologije

Zbornik radova Pravnog fakulteta, Novi Sad

Bioethik und Bildung. Bioethics and Education

The End of Animal Life

The Voices and Rooms of European Bioethics

Bioetika i dijete

Od nove medicinska etike do integrativne bioetike

Ethical Reasoning in Big Data

Ethics of Emerging Biotechnologies

9. Bioethik-Weltkongress

Fritz Jahr and the Foundations of Global Bioethics

Public Health Ethics: Cases Spanning the Globe

Bioethics - the sign of a new era: Proceedings

Integrative Bioethik

Integrative Bioethik: Grundlagen und Konkretionen

Tierschutz bei der religiösen Schlachtung

Visao Critica da Biotecnologia

Normativität des Lebens - Normativität der Vernunft?

Bioethik und kulturelle Pluralität

Wert und Würde der nichtmenschlichen Kreatur

Neutvrdivo

Total
3

2

2

2

2

2

2

2 


\section{PRILOG 3. Izračun Lotkinog zakona}

Utvrđivanje opaženih i očekivanih frekvencija prema Lotkinom zakonu $(C=159, n=2)$

\begin{tabular}{|r|r|r|r|r|r|}
\hline $\begin{array}{c}\text { Produktivnost } \\
(\mathbf{x})\end{array}$ & \multicolumn{1}{c|}{$\begin{array}{c}\text { Autori } \\
(\mathbf{y})\end{array}$} & $\begin{array}{c}\text { Opažene } \\
\text { frekvencije }\end{array}$ & $\begin{array}{c}\text { Produktivnost } \\
(\mathbf{x})\end{array}$ & $\begin{array}{c}\text { Autori } \\
(\mathbf{y})\end{array}$ & $\begin{array}{c}\text { Očekivane } \\
\text { frekvencije }\end{array}$ \\
\hline 1 & 159 & $71.95 \%$ & 1 & 159 & $64.11 \%$ \\
\hline 2 & 32 & $14.48 \%$ & 4 & 40 & $16.03 \%$ \\
\hline 3 & 7 & $3.17 \%$ & 9 & 18 & $7.12 \%$ \\
\hline 4 & 4 & $1.81 \%$ & 16 & 10 & $4.01 \%$ \\
\hline 5 & 6 & $2.71 \%$ & 25 & 6 & $2.56 \%$ \\
\hline 6 & 4 & $1.81 \%$ & 36 & 4 & $1.78 \%$ \\
\hline 7 & 1 & $0.45 \%$ & 49 & 3 & $1.31 \%$ \\
\hline 8 & 2 & $0.90 \%$ & 64 & 2 & $1.00 \%$ \\
\hline 9 & 1 & $0.45 \%$ & 81 & 2 & $0.79 \%$ \\
\hline 10 & 2 & $0.90 \%$ & 100 & 2 & $0.64 \%$ \\
\hline 13 & 1 & $0.45 \%$ & 169 & 1 & $0.38 \%$ \\
\hline 20 & 2 & $0.90 \%$ & 400 & 0 & $0.16 \%$ \\
\hline
\end{tabular}

Usporedba opaženih i očekivanih frekvencija Hi-kvadrat testom (Lotkin zakon)

\begin{tabular}{|c|c|c|c|c|c|}
\hline $\begin{array}{l}\text { Produktivnost } \\
(\mathbf{x})\end{array}$ & $\begin{array}{c}\text { Opažene } \\
\text { frekvencije } \\
\text { autora (Fi) }\end{array}$ & $\begin{array}{l}\text { Očekivane } \\
\text { frekvencije } \\
\text { autora (Pi) }\end{array}$ & Fi-Pi & $(\mathbf{F i}-\mathbf{P i})^{2}$ & $(\mathbf{F i}-\mathbf{P i})^{2} / \mathbf{P i}$ \\
\hline 1 & 159 & 159 & 0 & 0 & 0.00 \\
\hline 2 & 32 & 40 & -8 & 60 & 1.51 \\
\hline 3 & 7 & 18 & -11 & 114 & 6.44 \\
\hline 4 & 4 & 10 & -6 & 35 & 3.55 \\
\hline 5 & 6 & 6 & 0 & 0 & 0.02 \\
\hline 6 & 4 & 4 & 0 & 0 & 0.04 \\
\hline 7 & 1 & 3 & -2 & 5 & 1.55 \\
\hline 8 & 2 & 2 & 0 & 0 & 0.09 \\
\hline 9 & 1 & 2 & -1 & 1 & 0.47 \\
\hline 10 & 2 & 2 & 0 & 0 & 0.11 \\
\hline 13 & 1 & 1 & 0 & 0 & 0.00 \\
\hline 20 & 2 & 0 & 2 & 3 & 6.46 \\
\hline & & & & $\begin{array}{r}\text { Chi-Square } \\
\left(\chi^{2}\right):\end{array}$ & 20.25 \\
\hline
\end{tabular}




\section{PRILOG 4. Izračun Bradfordovog zakona}

Opažene frekvencije broja časopisa koji objavljuju određenu opaženu frekvenciju broja članaka

\begin{tabular}{|r|r|r|r|}
\hline $\begin{array}{c}\text { Broj časopisa koji } \\
\text { objavljuju određenu } \\
\text { opaženu frekvenciju } \\
\text { broja članaka } \\
\text { N(j) }\end{array}$ & Broj članaka & $\begin{array}{c}\text { Broj časopisa } \\
\text { kumulativno } \\
\text { C(j) }\end{array}$ & $\begin{array}{c}\text { Broj članaka } \\
\text { kumulativno } \\
\text { C(a) }\end{array}$ \\
\hline 1 & 52 & 1 & 52 \\
\hline 1 & 30 & 2 & 82 \\
\hline 1 & 15 & 3 & 108 \\
\hline 2 & 11 & 5 & 115 \\
\hline 1 & 7 & 6 & 120 \\
\hline 3 & 5 & 9 & 124 \\
\hline 3 & 4 & 12 & 127 \\
\hline 2 & 3 & 14 & 129 \\
\hline 14 & 2 & 28 & 130 \\
\hline 59 & 1 & 87 & \\
\hline
\end{tabular}

Izračun organizacije časopisa u tri Bradfordove zone

\begin{tabular}{|c|c|c|c|c|c|}
\hline $\mathbf{k = 4 . 5 2 4 3 4 5}$ & $\mathbf{k - 1}$ & $\mathbf{k} \wedge \mathbf{3}$ & $\mathbf{T}(\mathbf{k - 1})$ & $\mathbf{( k \wedge 3 - 1 )}$ & $\begin{array}{c}\mathbf{T}(\mathbf{k}-\mathbf{1}) \\
\mathbf{I} \\
\left(\mathbf{k}^{\wedge} \mathbf{3}-\mathbf{1}\right)\end{array}$ \\
\hline $\mathrm{r} 0$ & 3.524345 & 92.612 & 306.6181 & 91.612 & $\begin{array}{l}3.34692 \\
\approx \mathbf{3}\end{array}$ \\
\hline
\end{tabular}

\begin{tabular}{|l|l|}
\cline { 2 - 2 } \multicolumn{1}{c|}{} & $\mathbf{r 0 * \mathbf { k }}$ \\
\hline $\mathrm{r} 1$ & 15.14262 \\
& $\approx \mathbf{1 5}$ \\
\hline
\end{tabular}

\begin{tabular}{|l|l|}
\cline { 2 - 2 } \multicolumn{1}{c|}{} & $\mathbf{r 0} \mathbf{*}^{\wedge} \mathbf{2}$ \\
\hline \multirow{2}{*}{$\mathrm{r} 2$} & $\begin{array}{l}68.51046 \\
\mathbf{0 6 9}\end{array}$ \\
\hline
\end{tabular}


Bradfordove zone u području integrativne bioetike

\begin{tabular}{|c|r|r|r|}
\hline Zone & \multicolumn{1}{|c|}{$\mathbf{N}(\mathbf{j})$} & \multicolumn{1}{|c|}{$\mathbf{N}(\mathbf{a})$} & \multicolumn{1}{l|}{$\mathbf{k}$ (stvarni) } \\
\hline r0 & 3 & 97 & - \\
\hline r1 & 15 & 167 & 2.989407 \\
\hline r2 & 69 & 246 & 4.971693 \\
\hline
\end{tabular}

Usporedba opaženih i očekivanih frekvencija Hi-kvadrat testom (Bradfordov zakon)

\begin{tabular}{|c|r|r|r|r|r|}
\hline Rangovi & $\begin{array}{c}\text { Opažena } \\
\text { frekvencija } \\
\text { članaka (Fi) }\end{array}$ & $\begin{array}{c}\text { Očekivana } \\
\text { frekvencija } \\
\text { članaka } \\
(\mathbf{P i})\end{array}$ & Fi-Pi & \multicolumn{1}{|c|}{ (Fi-Pi) $^{\mathbf{2}}$} & (Fi-Pi) $\mathbf{2}^{\mathbf{2}} \mathbf{\text { Pi }}$ \\
\hline 3 & 246 & 234 & 12 & 144 & 0.615385 \\
\hline 2 & 167 & 153 & 14 & 196 & 1.281046 \\
\hline 1 & 97 & 77 & 20 & 400 & 5.194805 \\
\hline
\end{tabular}




\section{ŽIVOTOPIS AUTORA S POPISOM OBJAVLJENIH DJELA}

Denis Kos rođen je 21. lipnja 1990. godine u Varaždinu, gdje je 2009. godine maturirao na Prvoj općoj gimnaziji Varaždin. Na Filozofskom fakultetu Sveučilišta u Zagrebu 2014. godine stekao je naziv magistra bibliotekarstva i pedagogije. Stručno se osposobljavao u knjižnicama Kineziološkog fakulteta i Filozofskog fakulteta Sveučilišta u Zagrebu, a 2016. godine zapošljava se na Filozofskom fakultetu kao asistent na Odsjeku za informacijske i komunikacijske znanosti (Katedra za organizaciju znanja) i u Centru za integrativnu bioetiku. Tijekom asistenture izvodi nastavu na kolegijima Epistemologija informacijske znanosti i Sustavi za označivanje i pretraživanje 1 i 2 . Kao član glavnog tajništva Znanstvenog centra izvrsnosti za integrativnu bioetiku vodi Znanstveno istraživački odbor „Bioetička pitanja u hrvatskome dnevnom tisku“ te uređuje informacijske i dokumentacijske sustave Referalnog centra za bioetiku u jugoistočnoj Europi. Sudjeluje u organizacijskim odborima nekoliko domaćih i međunarodnih znanstvenih i stručnih skupova. Istražuje područja interdisciplinarne i transdisciplinarne organizacije znanja, kritičkog knjižničarstva, informacijske i podatkovne pismenosti, integrativne bioetike i sadržajne analize. Član je Odbora za doktorske programe Sveučilišta u Zagrebu, Programskog odbora Europske konferencije o informacijskoj pismenosti, Kruga mladih urednika časopisa Filozofska istraživanja, Upravnog odbora Hrvatskog informacijskog i dokumentacijskog društva, Zagrebačkog knjižničarskog društva, Hrvatskog bioetičkog društva, Međunarodnog udruženja za organizaciju znanja te međunarodne istraživačke mreže Navigating Knowledge Landscapes.

\section{Projekti}

- Suradnik na projektu ,Zdravlje i znanje u perspektivi filozofije i informacijskih znanosti: primjer pandemije koronavirusa“. Sveučilište u Zagrebu (2020). Voditelj projekta: prof. dr. sc. Hrvoje Jurić.

- Suradnik na projektu „ERASMUS+ Strategic Partnerships for Higher Education „Introducing Intellectual Property Education for Lifelong Learning and the Knowledge Economy (IPEDU)“ (2020), Koordinator projekta: Limerick Institute of Technology, Irska.

- Suradnik na projektu „Istraživački horizonti kritičkih podatkovnih studija i algoritamske culture“. Sveučilište u Zagrebu (2018-2019). Voditelj projekta: prof. dr. sc. Sonja Špiranec. 
- Suradnik na projektu „Filozofski i odgojni aspekti suosjećanja“. Sveučilište u Zagrebu (2016-2017). Voditelj projekta: izv. prof. dr. sc. Ivana Zagorac.

\section{Bibliografija}

1. Kos, D., Kos, M., \& Jurić, H. (2020). Integrative bioethics and knowledge landscapes. U: Svalastog, A. L.; Gajović, S.; Webster, A. (ur.) Navigating digital health landscapes : a multidisciplinary analysis. Singapore : Palgrave MacMillan, 2020. Str. $67-88$.

2. Špiranec, S., Kos, D., \& Michael, G. (2019). Searching for critical dimensions in data literacy. Information research, 24 (4), 1922, 12.

3. Kos, D., Špiranec, S., \& Čović, A. (2018). Mapping perspectival ambiguity in bioethics : revisiting the viewpoint warrant. U: Ribeiro, F. \& Cerveira, M. (ur.) Challenges and Opportunities for Knowledge Organization in the Digital Age: proceedings of the Fifteenth International ISKO Conference, 9-11 July, 2018, Porto, Portugal. Porto : International Society for Knowledge Organization (ISKO); University of Porto, Faculty of Arts and Humanities; Research Centre in Communication, Information and Digital Culture. Str. 959-961.

4. Špiranec, S., \& Kos, D. (2018). Data Literacy and Research Data Management : The Croatian State of Affairs. U: Kurbanoğlu, S., Boustany, J., Špiranec, S., Grassian, E., Mizrachi, D. \& Roy, L. (ur.) Information Literacy in the Workplace : 5th European Conference, ECIL 2017, Saint Malo, France, September 18-21, 2017, Revised Selected Papers. Heidelberg : Springer International Publishing. Str. 148-157.

5. Grkinić, A., Kos, D., \& Špiranec, S. (2017). FRSAD i problematična stvarnost sadržajne analize. U: Purgarić-Kužić, B. \& Špiranec, S. (ur.) Predmetna obrada : pogled unaprijed : zbornik radova. Zagreb : Hrvatsko knjižničarsko društvo. Str. 7993.

6. Špiranec, S., Banek Zorica, M., \& Kos, D. (2016). Information Literacy in participatory environments : the turn towards a critical literacy perspective. Journal of documentation, 72 (2), 247-264.

7. Kos, D., \& Špiranec, S. (2015). Understanding the field of critical information literacy : a descriptive analysis of scientific articles. U: Kurbanoğlu, S., Boustany, J., Špiranec, S., Grassian, E., Mizrachi, D. \& Roy, L. (ur.) Information Literacy : Moving Toward Sustainability. Heidelberg : Springer International Publishing. Str. 579-589. 
8. Čnč, T., \& Kos, D. (2015). Welcome to the jungle : science communication in the mediatized society. U: Anderson, K., Duranti, L., Jaworski, R., Stančić, H., Seljan, S. \& Mateljan, V. (ur.) InFuture2015 : E-institutions - openness, accessibility and preservation. Zagreb : Department of Information and Communication Sciences, Faculty of Humanities and Social Sciences, University of Zagreb. Str. 367-376.

9. Garić, A., Kos, D., \& Stančić, H. (2015). Radionica o osnovnim metodama zaštite knjižnične građe i arhivskoga gradiva : primjer pedagoške aktivnosti za studente u arhivu. U: Cupar, D. \& Martek, A. (ur.) 18. seminar Arhivi, knjižnice, muzeji : mogućnosti suradnje u okruženju globalne informacijske infrastrukture "Globalno i lokalno, lokalno i globalno - glocal" : zbornik radova. Zagreb : Hrvatsko muzejsko društvo. Str. 324-326.

10. Kos, D., \& Špiranec, S. (2014). Debating Transformative Approaches to Information Literacy Education : A Critical Look at the Transformative Learning Theory. U: Kurbanoğlu, S., Špiranec, S., Grassian, E., Mizrachi, D., Catts \& Ralph (ur.) Information Literacy. Lifelong Learning and Digital Citizenship in the 21st Century. Cham [etc.] : Springer. Str. 427-435.

11. Kos, D., Mesić, J., \& Špiranec, S. (2014). Information literacy in the context of student activism. U: Taskin, Z., Cakmak, T. \& Dogan, G. (ur.) Proceedings of the 21 st International BOBCATSSS conference : from collections to connections, turning libraries inside out. Ankara : Hacettepe University Department of Information Management. Str. 15-19.

12. Špiranec, S., \& Kos, D. (2013). Information literacy practices and student protests : mapping community information landscapes. Information research, 18 (S3), C39-1.

\section{Izlaganja}

1. Kos, D. (2019). Ethical issues in critical data literacy discourse. U: Jurić, H. (ur.) 18. Lošinjski dani bioetike, Mali Lošinj, Hrvatska, 19.-22. svibnja 2019. Zagreb : Hrvatsko filozofsko društvo. Str. 45. (sažetak)

2. Kos, D. (2018). An integrative bioethics approach to digital online communication. Izloženo na: SRA-E 2018: Risk \& Uncertainty - From Critical Thinking to Practical Impact (SRA-E 2018). Mid Sweden University, Östersund, Sweden, 18-20.06.2018. 
3. Kos, D. (2018). Information literacy education and access to health. U: Jurić, H. (ur.) 17. Lošinjski dani bioetike, Mali Lošinj, Hrvatska, 20.-23. svibnja 2018. Zagreb : Hrvatsko filozofsko društvo, 2018. Str. 50. (sažetak)

4. Kos, M., \& Kos, D. (2018). From Bioethics to Literacy : Further Interdisciplinary Remarks for the Big Data Debate. Izloženo na: International Workshop Big Data in Healthcare, Zagreb (Croatia) October 12-14, 2018. Zagreb, Hrvatska, 1214.10.2018.

5. Kos, D. (2018). Transdisciplinary Knowledge Organization : An Explorative Strategy to Map Perspectival Ambiguity. Izloženo na: Libraries in the Digital Age (LIDA) 2018. Zadar, Hrvatska, 13-15.06.2018.

6. Kos, D. (2017). Knowledge or Information Landscapes? LIS Approaches to the Landscapes Metaphor. Izloženo na: Symposium on cross-disciplinary research in the health humanities and beyond: perspectives and knowledge landscapes in the digital society. Amsterdam, Nizozemska, 15.12.2017.

7. Kos, D., \& Knorr, L. (2017). The concept of standpoints in knowledge organization. U: Jurić, H. (ur.) 16. Lošinjski dani bioetike, Mali Lošinj, Hrvatska, 14.-17. svibnja 2017. Zagreb : Hrvatsko filozofsko društvo. Str. 84. (sažetak)

8. Kos, D., \& Špiranec, S. (2017). Podatkovna pismenost : temeljni izazov otvorene znanosti u Hrvatskoj?. Izloženo na: Dani e-infrastrukture 2017. Zagreb, Hrvatska, 5.4.2017.

9. Grkinić, A., Kos, D., \& Špiranec, S. (2016). FRSAD i problematična stvarnost sadržajne analize. U: Purgarić-Kužić, B. (ur.) Predmetna obrada : pogled unaprijed : programska knjižica. Zagreb : Hrvatsko knjižničarsko društvo. Str. 31-32. (sažetak)

10. Kos, D. (2016). Teorijsko utemeljenje transdisciplinarne organizacije znanja u području (integrativne) bioetike. U: Jurić, H. (ur.) 15. Lošinjski dani bioetike, Mali Lošinj, Hrvatska, 15.-18. svibnja 2016. Zagreb : Hrvatsko filozofsko društvo. Str. 75. (sažetak)

11. Kos, D. (2016). Transdisciplinary Knowledge Organization Systems : Heightening the Complexity of Knowledge Representation in Bioethics. Izloženo na: Bioethik als wissenschaftliches und gesellschaftliches Projekt : Die Idee einer integrativen Bioethik. Tutzing, Njemačka, 20.06.-26.06.2016. 